\title{
AVALIAÇÃO DE QUATRO FORRAGEIRAS TROPICAIS CULTIVADAS EM DOIS SOLOS DA ILHA DE MARAJÓ-PA SUBMETIDOS A CRESCENTES SATURAÇÕES POR BASES
}

\section{Getulio faciola Pessoa Bonneterre Guimarães}

ZOOTECNISTA

Orientador: Prof. Dr. HeRbert Barbosa de Mattos

Dissertação apresentada à Escola Superior de Agricultura "Luiz de Queiroz" da Universidade de São Paulo, para obtenção do título de Mestre em Agronomia, Área de Concentração: Ciência Animal e Pastagens. 
Dados Internacionais de Catalogaçāo na Publicaçāo (CIP) DIVISĀo dE BIBLIOTECA E DOCUMENTAÇĀO - Campus "Luiz de Oueiroz"/USP

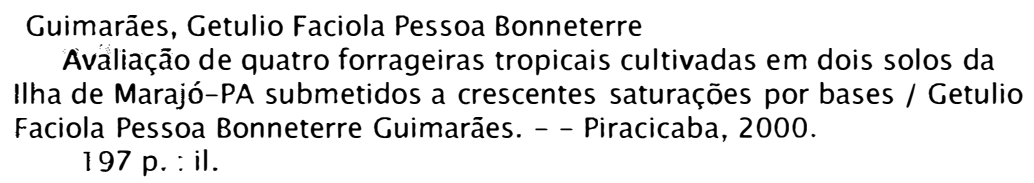

Dissertação (mestrado) - - Escola Superior de Agricultura Luiz de Queiroz, 2000.

Bibliografia.

1. Alumínio 2. Calagem 3. Calcário 4. Cálcio 5. Capim braquiaria 6. Capim canarana 7. Gramínea forrageira 8. Magnésio 9. Nutrição mineral 10. Saturação por base I. Título 


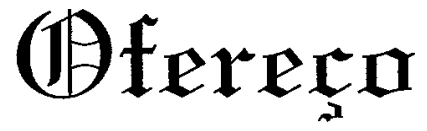

Aos meus queridos pais:

\section{Getulio Bonneterre Guimarães \\ $\mathcal{Q}$ \\ Maria Stella Faciola Pessoa Guimarães}

pelo constante incentivo e apoio em todas as etapas de minha vida 


\section{AgRADECIMENTIS}

À Escola Superior de Agricultura Luiz de Queiroz (USP) e em especial ao Departamento de Produção Animal, pela oportunidade de realização deste curso.

À Universidade Federal de Viçosa (UFV), por minha formação acadêmica.

À Fundação de Amparo a Pesquisa do Estado de São Paulo (FAPESP), pela concessão da bolsa de estudos e auxílio à pesquisa durante o transcorrer do curso.

À mineradora Rio Formoso pela doação do calcário utilizado neste experimento.

Ao Prof. Dr. Herbert Barbosa de Mattos, pela orientação, amizade e liberdade na escolha do tema de pesquisa, possibilitando desta forma a oportunidade de estudar um pouco sobre minha região, tão carente de pesquisas.

Ao Prof. Dr. Ricardo Ferraz pela confiança em mim depositada e em disponibilizar o Laboratório de Plantas Cultivadas Sob Condições de Estresse a livre utilização para o desenvolvimento deste projeto.

Aos demais Professores da ESALQ pelos ensinamentos adquiridos através das disciplinas cursadas, pela amizade e exemplo profissional.

Ao pesquisador Dr. Hélio do Prado pelo auxílio na classificação dos solos utilizados neste experimento.

Aos estagiários André, Primata e Chicotinho que me acompanharam em algumas fases do experimento.

Aos amigos Cláudio, Shozo, Michelle, Elcione Jr., Beth, Belisa, Paula, Rita, que por muitas vezes se passaram por estagiários, caso contrário, não seria possível avaliar tantos parâmetros, que muito enriqueceram esta pesquisa.

Aos amigos e colegas de curso Sérgio, Cláudio, Carlos Augusto, Rafael pela amizade companheirismo durante o transcorrer do curso.

À Paola Gabarra que me acompanhou e muito me ajudou nas etapas finais de excussão e redação da Dissertação.

Ao funcionário Carlos César do Laboratório de Bromatologia, pela amizade, ensinamentos e pela colaboração nas análises laboratoriais.

Às funcionárias do Laboratório de Solos e Nutrição de Plantas Lúcia, Néia, Lurdes e Nirvanda pela colaboração nas análises laboratoriais.

Aos demais funcionários e colegas do curso de pós-graduação, pela amizade, pela ajuda e pela agradável convivência.

Às pessoas que, direta ou indiretamente, contribuíram para a realização deste trabalho. 


\section{SUMÁRID}

LISTA DE ABREVIAÇÕES ......................... VII

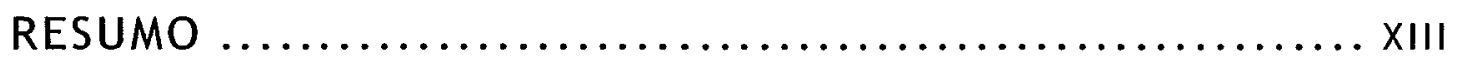

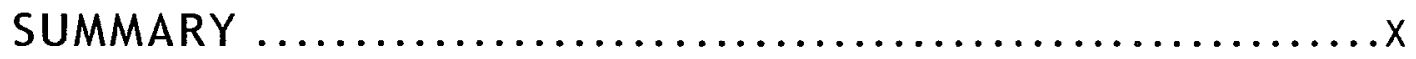

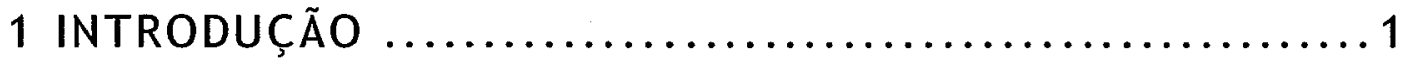

2 REVISÃO DE LITERATURA $\ldots \ldots \ldots \ldots \ldots \ldots \ldots \ldots \ldots \ldots$

2.1 Localização, clima e solos da Itha de Marajo .....................4

2.2 Espécies forrageiras estudadas ................................6

2.2.1 Brachiaria humidicola ............................................6

2.2.2 Brachiaria mutica ..............................................6

2.2.3 Echinochloa pyramidalis ...................................... 7

2.2.4 Echinochloa polystachya ....................................... 8

2.3 Acidez do solo ..................................................9

2.3.1 Origem da acidez dos solos ...................................9

2.3.2 Alumínio como componente da acidez do solo ................... 12

2.4 Efeitos da acidez no solo ..................................... 15

2.4.1 Alumínio versus nutrição e adaptação ........................... 17

2.5 Correção da acidez do solo .....................................20

2.5.1 Método da incubação ........................................ 20

2.5.2 Método baseado na elevação de saturação por bases .............. 21

2.5.3 Princípio da correção da acidez do solo .........................22

2.5.3.1 Qualidade dos corretivos ..................................24

2.6 Cálcio e magnésio como nutrientes ............................26

2.6.1 Cálcio ........................................................26

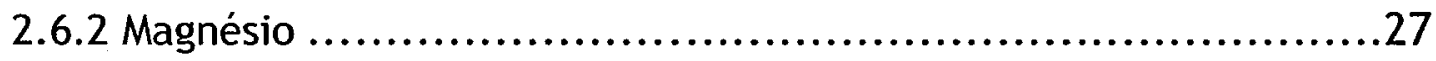


2.7 Espécies forrageiras e acidez do solo ..........................28

2.7.1 Efeitos na produção de matéria seca ............................28

2.7.2 Efeito na composição química da forragem .......................35

2.7.3 Desenvolvimento do sistema radicular ............................37

3 MATERIAL E MÉTODOS .......................... 40

3.1 Local e período .................................................40

3.2 Espécies de gramíneas avaliadas ................................ 40

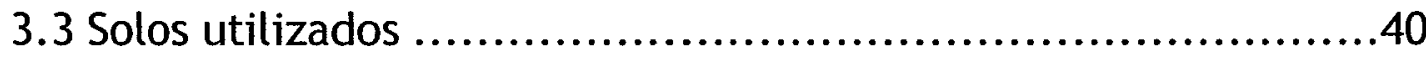

3.3.1 Origem e coleta ..............................................40

3.3.2 Características físico-químicas ...............................41

3.3.3 Classificação ............................................... 42

3.4 Pré-ensaio de incubação ......................................45

3.5 Delineamento experimental .................................... 46

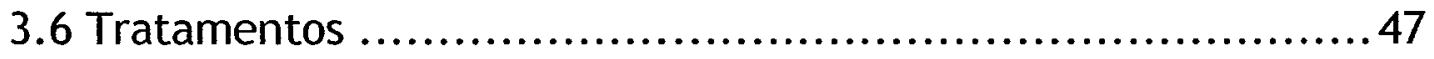

3.6.1 Adubações realizadas .........................................48

3.7 Parâmetros analisados e metodologias empregadas .............49

3.7.1 Determinações no material vegetal .............................49

3.7.2 Determinações no solo .......................................51

3.8 Preparação e desenvolvimento do experimento .................52

3.8.1 Obtenção das mudas ...........................................52

3.8.2 Preparação, plantio e condução ...............................5 53

3.8.3 Coleta dos dados experimentais ............................... 57

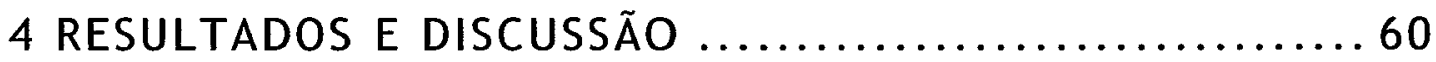

4.1 Pré-ensaio de incubação ......................................60

4.2 Comportamento químico do solo ............................. 70 
4.2.1 Saturações por bases pretendidas versus alcançadas ...............71

4.2.2 Calagem e disponibilidade dos nutrientes após a incubação ........72

4.2.3 Comportamento do solo ao longo do tempo ....................... 74

4.3 Produção de tecido vegetal ..................................97

4.3.1 E. Polystachya ................................................... 97

4.3.2 E. Pyramidalis ............................................... 100

4.3.3 B. mutica ....................................................... 103

4.3.4 B. humidicola ...................................................110

4.3.5 Considerações finais sobre a produção ...........................114

4.4 Composição química das folhas ............................... 132

4.4.1 Fósforo .................................................... 132

4.4.2 Potássio ......................................................134

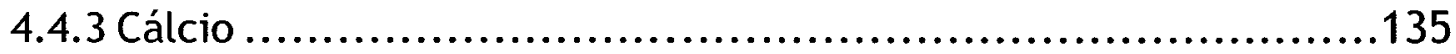

4.4.4 Magnésio ...................................................140

4.4.5 Relação cálcio/magnésio ......................................142

4.4.6 Sódio ......................................................144

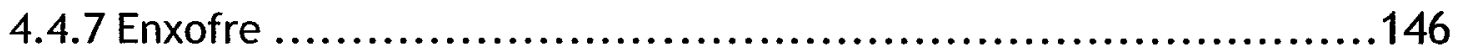

4.4.8 Cobre, ferro, manganês e zinco ..............................147

4.4.9 Boro ............................................................ 149

4.4.10 Considerações finais sobre composição química ..................155

4.5 Análise bromatológica .........................................168

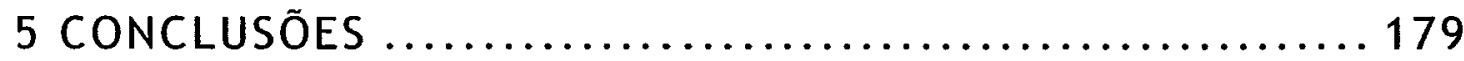

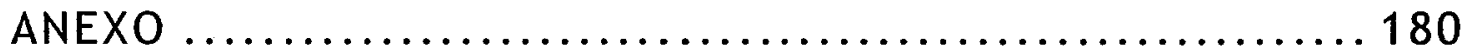

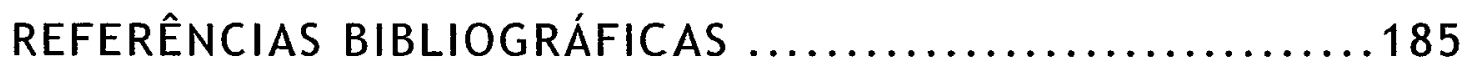

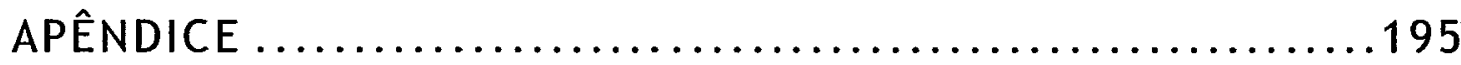




\section{LISTA DE ABREVIAḈ̃ES}

\begin{tabular}{|c|c|c|}
\hline Sigla & Descrição & Unidade \\
\hline AF- & Área foliar & $\mathrm{cm}^{2}$ \\
\hline CTC- & Capacidade de troca de cátions & $\mathrm{mmol}_{\mathrm{c}} \mathrm{dm}^{-3}$ \\
\hline FDA - & Fibra em detergente ácido & $\%$ \\
\hline FDN - & Fibra em detergente neutro & $\%$ \\
\hline m- & Saturação por alumínio & $\%$ \\
\hline MM - & Matéria mineral & $\%$ \\
\hline MNT- & Matéria natural total (parte aérea) & $\mathbf{g}$ \\
\hline MO - & Matéria orgânica & $\mathrm{g} \mathrm{kg}^{-1}$ \\
\hline MS - & Matéria seca & - \\
\hline MSF- & MS de folhas & $\mathbf{g}$ \\
\hline MSFE- & MS de lâminas foliares expandidas & g \\
\hline MSFEE- & MS de lâminas foliares em expansão & $\mathbf{g}$ \\
\hline MSH- & MS de Haste & $\mathbf{g}$ \\
\hline MSR- & MS de raises & $\mathbf{g}$ \\
\hline MST- & MS Total (parte aérea) & $\mathbf{g}$ \\
\hline MST+R- & $\mathrm{MST}+\mathrm{MSR}$ & $\mathbf{g}$ \\
\hline MSTR- & MST relativa ( $\%$ da Testemunha) & $\%$ \\
\hline NP. & Número de perfilhos & unid. \\
\hline PB - & Proteina bruta & $\%$ \\
\hline RFH- & Relação MSF/MSH & - \\
\hline TA- & Taxa de acúmulo de MST & g dia ${ }^{-1}$ \\
\hline TAF. & Taxa de acúmulo de MSF & $\mathrm{g} \mathrm{dia}^{-1}$ \\
\hline TMS- & Teor de MS & $\%$ \\
\hline V- & Saturação por bases & $\%$ \\
\hline \multicolumn{3}{|c|}{$\begin{array}{l}\mathbf{V}^{* *} \text { - Saturação por bases final para cada tratamento; } \\
* * \text { - valor numérico }\end{array}$} \\
\hline
\end{tabular}




\title{
AVALIAÇÃO DE QUATRO FORRAGEIRAS TROPICAIS CULTIVADAS EM DOIS SOLOS DA ILHA DE MARAJÓ-PA SUBMETIDOS A CRESCENTES SATURAÇÕES POR BASES
}

\author{
Autor: Getulio Faciola Pessoa BonNeterRe Guimarães \\ Orientador: Prof. Dr. HERBERT Barbosa de MATtOS
}

\section{RESUMO}

Quatro espécies de gramíneas forrageiras tropicais [Brachiaria mutica (Forsk) Stapf, Brachiaria humidicola (Rendle) Schweickerdt, Echinochloa pyramidalis (Lan.) Hitch. \& Chase e Echinochloa polystachya (H.B.K) Hitch.] foram submetidas a valores crescentes de saturação por bases, em dois solos distintos [Plintossolo pétrico litoplíntico (solo1) e Plintossolo háplico eutrófico (solo2)] da Ilha de Marajó-PA, com a intenção de se determinar sob condições de casa de vegetação qual saturação possibilita maior produção de matéria seca, aliada à nutrição mineral adequada.

O delineamento estatístico foi inteiramente ao acaso com 5 tratamentos e 3 repetições, onde cada espécie cultivada em cada tipo de solo constituía um delineamento independente, perfazendo 8 ensaios no total. Os tratamentos estabelecidos foram 10, 30, 50,70 e $90 \%$ de saturação por bases para o solo1 e $15,35,55,75$ e $95 \%$ para o solo2. A quantidade de calcário utilizada para cada tratamento foi estabelecida através de equações geradas em um pré-ensaio de incubação realizado exclusivamente para esta finalidade.

Foram coletadas informações sobre produção da parte aérea por três cortes consecutivos, sendo no ato do terceiro corte quantificada a produção total de raízes. A cada corte foram também quantificados os números de perfilhos produzidos, sendo o material vegetal coletado submetido à composição botânica, separando-se em 3 frações 
distintas (lâminas foliares em expansão, lâminas foliares expandidas e caule+bainha). No segundo e terceiro corte as áreas foliares foram mensuradas.

As folhas foram analisadas para determinação de macro e microminerais, bem como para proteína bruta (PB), fibra em detergente neutro (FDN), fibra em detergente ácido (FDN), lignina e digestibilidade "in vitro" da matéria orgânica (DIVMO). Após o período de incubação dos solos e àpós cada corte foram realizadas coletas de amostras de solo para analise.

Devido às elevadas adubações nitrogenadas realizadas, houve aumento da acidificação dos solos ao longo dos cortes realizados, sendo que as parcelas testemunhas de ambos os solos apresentaram saturação de $\mathrm{Al}$ acima de $90 \%$ ao final do experimento, tendo-se porém, constatada evidente diferença de poder tampão entre os solos avaliados.

As respostas nos parâmetros de produção de parte aérea e raízes variaram com a espécie e com o tipo de solo. Podendo-se classificar pelos resultados obtidos a seguinte ordem decrescente das espécies avaliadas em relação à necessidade de calagem: $B$. mutica $>$ E. pyramidalis $>$ E. polystachya $>$ B. humidicola.

O benefício da calagem esteve estreitamente relacionado ao fornecimento de cálcio e em menor grau ao de magnésio, já que em todas ocasiões em que a calagem interferiu significativamente a produção, 90\% desta foi alcançada na primeira dose de calcário utilizada, situação esta em que os solos ainda apresentavam elevada acidez e altos teores de Al trocável.

Em relação à composição das folhas, na maioria das oportunidades observaramse aumentos nos teores de $\mathrm{Ca}$ e $\mathrm{Mg}$, relação $\mathrm{Ca} / \mathrm{Mg}$ e $\mathrm{B}$; reduções nos teores de $\mathrm{Na}, \mathrm{Fe}$, Mn e Zn e não efeitos significativos para P, K, S, PB, FDN, FDA, DIVMO e lignina em função das crescentes saturações por bases avaliadas. Contudo variações foram observadas para as diferentes espécies vegetais bem como entre os solos avaliados. 


\title{
EVALUATION OF FOUR TROPICAL PASTURE CROPS, CULTIVATED ON TWO DIFFERENTS SOILS FROM MARAJÓ ISLAND UNDER INCREASING BASE CATIONS STAURATION RATIO
}

\author{
Author: GeTUlio FACIOLA PESSOA BonNeTERRE GUIMARÃES \\ AdVISER: PROF. DR. HERBERT BARBOSA DE MATTOS
}

\section{SUMMARY}

Four tropical pasture species [Brachiaria mutica (Forsk) Stapf, Brachiaria humidicola (Rendle) Schweickerdt, Echinochloa pyramidalis (Lan.) Hitch. \& Chase and Echinochloa polystachya (H.B.K) Hitch.], were grown in greenhouse, cultivated on two differents types of soil [Plintossolo pétrico litoplíntico (soill) e Plintossolo háplico eutrófico (soil2)] under increasing basic cations saturation ratio (BCSR), in order to determine the best BCSR to maximize dry matter yield and to provide an ideal mineral nutrition.

Eight experiments were done using a complete randomized design for statistical analysis, with five treatments and 3 replicates, where one tropical pasture species and one type of soil was an independent trial. The five BCSR were 10, 30, 50, 70 and $90 \%$ for soil 1 and 15, 35, 55, 75 and $95 \%$ for soil 2, due to the addition of limestone. The exact amount of limestone for each treatment was determined by equations previously obtained by a limestone incubation test.

Shoot and tiller production were measured for 3 consecutive cuts, and root production in the last one. The shoot material was separated in each cut into three fractions (young leaf blades, mature leaf blades and leaf sheath + stem). Leaf area was measured in the second and third cuts.

Mineral composition, crude protein (CP), neutral detergent fiber (NDF), acid detergent fiber (ADF), lignin and "in vitro" organic matter digestibility (IVOMD) were 
analyzed in the leaves. Soil samples were collected after limestone incubation period and at each shoot cut.

Due to heavy nitrogen fertilizations, soil acidification increased over the experiment, and both soils reached over $90 \%$ of $\mathrm{Al}$ saturation ratio in some treatments. An evident difference on buffering capacity between soils was observed.

The shoot and root dry matter yield showed variation among pasture species and soils. These results allowed the ranking of pasture species according to a decreasing limestone requirements, as follows: B. mutica $>$ E. pyramidalis $>$ E. polystachya $>B$. humidicola.

The major benefit of limestone application was related to calcium and magnesium fertilization. Every time when differences were observed among treatments, there were no statistical differences among treatments with lime stone addition. However, the control treatment (0 limestone) was different from the remaining treatments.

The increase in base cations saturation ratios in the soil increased $\mathrm{Ca}, \mathrm{Mg}, \mathrm{Ca} / \mathrm{Mg}$ and $\mathrm{B}$; while decrease $\mathrm{Na}, \mathrm{Fe}, \mathrm{Mn}$, e $\mathrm{Zn}$; and showed no effects on $\mathrm{P}, \mathrm{K}, \mathrm{S}, \mathrm{PB}, \mathrm{NDF}$, $\mathrm{ADF}, \mathrm{IVOMD}$, lignin concentrations in most of the observations in the leaves. Therefore variation among pasture species and soil type was observed, and must be taken in to account. 


\section{INTRロDUÇÃ}

A principal exploração econômica da Ilha de Marajó está sedimentada em uma pecuária de corte de bovinos e bubalinos extremamente extensiva, caracterizada pelo uso mínimo de insumos; aproveitando-se, há séculos, dos extensos campos naturais encontrados na ilha. Evidentemente este tipo de pecuária não consegue competir com as demais regiões produtoras do País, e muito menos no mercado internacional na era do mundo globalizado.

O caráter extrativista, sustentado em campos de solos pouco férteis e com espécies forrageiras nativas pouco produtivas, aliadas à poucas ou muitas vezes nenhuma prática zootécnica, faz com que esta bovinocultura desfrute de péssimos índices zootécnicos. Este cenário de baixa produtividade, em decorrência do desconhecimento de novas e adequadas tecnologias que possam ser aplicadas a esta região, tem forçado muitos produtores a abandonar a atividade pecuária.

O aumento da produção de carne ou leite a pasto implica em conhecimentos sobre espécime animal, nutrição, melhoramento genético, manejo adequado do rebanho, controle sanitário, dentre outras práticas zootécnicas. Acreditando que o aumento da produtividade das forrageiras, dentro deste cenário apresentado, seja a principal ferramenta para se aumentar a competitividade do sistema; tem-se como premissa para se atingir este objetivo, além da escolha adequada do pasto que melhor se adapte às condições edafoclimáticas da região, um manejo conveniente da espécie em questão, bem como uma nutrição mineral adequada e equilibrada para cada forrageira. 
Além destas características já descritas sobre a região, deve-se também não esquecer que se trata de uma ilha, portanto, qualquer investimento em melhoria da pecuária onde se necessite adquirir grandes quantidades de insumos, como no caso de corretivos e fertilizantes, estes terão seus custos elevados pelo transporte, principalmente no caso da calagem, onde o corretivo é empregado em cifras de toneladas por hectare.

Acrescenta-se ainda a esta realidade geográfica, o custo de fertilizantes e corretivos, que é muito mais alto no Estado do Pará, devido a sua pouca tradição na agricultura (notadamente na produção de grãos), quando comparada às outras regiões produtoras do Brasil. Logo, práticas como a calagem, que envolvem volumes consideráveis de insumo, devem ser muito bem definidas para que se atinja um melhor custo-benefício possível.

A calagem é uma prática agrícola muito antiga, já usada inclusive pelos romanos. Entretanto, até hoje, a sua recomendação com base nas análises do solo, tem sido motivo de muita controvérsia nos meios científicos, especialmente na área de pastagens tropicais. As espécies tropicais, apesar de na maioria das vezes serem enquadradas como espécimes tolerantes à acidez do solo, quando adequadamente manejadas, possuem um incrível potencial de produção de matéria seca, o que irá demandar um expressivo fornecimento de nutrientes vindo do sistema solo, portanto, o calcário passa a ter fundamental importância como fornecedor de cálcio e magnésio.

A eficiência da calagem depende de diversos fatores. Os ligados à planta, a qual a confere maior ou menor tolerância à acidez dos solos, possibilitando ou não formar um sistema radicular capaz de supri-la adequadamente em água e nutrientes. Os fatores ligados ao solo que são dependentes do complexo coloidal, do grau de acidez, da capacidade de reter água e fornecer os nutrientes para as plantas, principalmente aqueles cujas disponibilidades são reduzidas pela calagem. E finalmente, quanto aos corretivos, referem-se à eficiência neutralizante, que por sua vez, depende de fatores intrínsecos aos corretivos como a riqueza de neutralizantes, granulometria, e ainda, de fatores externos como a homogeneidade de distribuição e de incorporação. 
O presente trabalho testou doses crescentes de calcário para algumas das espécies forrageiras naturalmente encontradas ou potencialmente promissoras para região, seja por adaptação climática, ou às condições de solo, aliado ainda aos fatores de produtividade e valor nutritivo.

A proposta deste estudo, portanto, foi realizar ensaios que demonstrassem os efeitos do calcário em dois solos distintos da Itha de Marajó, bem como a interferência deste na produtividade e composição química de quatro espécies de forrageiras, a fim de se gerar conhecimento para a indicação de uma dose ótima de utilização deste insumo. Tais resultados gerados poderão servir de base para um estudo econômico de implantação de pastos mais produtivos para a região, que irá denotar, em última análise, uma pecuária mais moderna e competitiva para os dias de hoje. 


\section{REVISÃO DE LITERATURA}

\section{1 LqCAlizaçÃa, clima e g}

A Ilha de Marajó é considerada a maior ilha fluvio-marítima do mundo, possuindo uma área total de aproximadamente $50.000 \mathrm{~km}^{2}$, ou seja, maior que muitos estados brasileiros, como por exemplo: Sergipe, Alagoas, Espírito Santo e Rio de Janeiro, ou ainda que muitos países como: Bélgica, Holanda, Dinamarca, Suíça, dentre muitos outros.

A Ilha de Marajó encontra-se no estuário do rio Amazonas em latitude subequatorial. Trata-se de um terreno sob formações sedimentares, com poucos metros acima do mar. O material de origem dos solos é formado por sedimentos fluviomarinhos argilosos. (Brasil, 1974). O clima é equatorial úmido, possuindo de três a quatro meses secos (setembro a dezembro), período no qual há ausência quase que total de precipitações, cenário que lembra o semi-árido nordestino. A média anual de precipitações é de $2900 \mathrm{~mm}$. A maior parte da ilha, no período chuvoso, é anualmente inundada, pois as águas das chuvas não escoam com facilidade em decorrência do relevo excessivamente plano, com solos na sua maioria de baixa permeabilidade associado ao elevado nível do lençol freático. $\stackrel{E}{E}$ sem dúvida nenhuma uma região de extremos contrastes climáticos.

A vegetação predominante na costa leste, onde se pratica a pecuária, é de campos naturais. São 2,3 milhões de hectares de savanas mal drenadas, usados há mais de 300 
anos pela pecuária extensiva, que atualmente reúne 600 mil cabeças de bovinos, 550 mil cabeças de bubalinos e cerca de 100 mil cabeças de eqüinos.

Na ilha, sob um mesmo tipo de vegetação de campo, são encontrados uma gama de solos: glei húmicos, pouco húmicos, plintossolos, distróficos, eutróficos, álicos, salinos e sódicos, possuindo argila tanto de alta como de baixa atividade.

Silva \& Carvalho (1991), ao caracterizarem solos da região amazônica, descrevem os solos dos tipos Glei húmico e Glei pouco húmico eutrofico e distrófico, como sendo solos hidromórficos, pobremente desenvolvidos e sujeitos a períodos de inundação. A alternância entre períodos de encharcamendo e seca resulta em condições de redução do ferro livre nos processos de oxidação, o que é indicado pela coloração cinza dos solos.

Estes solos pobremente drenados possuem características químicas específicas. São solos na maioria das vezes álicos, possuindo baixa soma e saturação por bases. Além disto a saturação de alumínio trocável é elevada, atingindo facilmente mais que $50 \%$ (Silva \& Carvalho, 1991).

Cerri \& Volkoff (1988), em um trabalho sobre matéria orgânica de três solos dos campos inundados da Ilha de Marajó, caracterizaram os solos encontrados como: desenvolvidos sobre sedimentos fluviomarinhos argilosos, constituídos de caulinita, ilita e montmorilonita (argilas de alta atividade). Nas partes mais elevadas do leste da ilha amostraram um solo planossólico; nas áreas mais baixas, onde a hidromorfia é mais prolongada, um solo glei e, nas partes intermediárias, onde há alternância de encharcamento e secagem, um vértico. O meio físico-químico interno é caracterizado em solo seco por nítida acidez em presença de sais solúveis como cloretos e sulfatos.

$\mathrm{O}$ teor de carbono total aumenta à medida que a hidromorfia se torna mais acentuada, sendo a indicação da diminuição da velocidade de humificação e da biodegradação dos compostos orgânicos devido a elevada umidade. Porém nenhum dos solos se apresenta como orgânico (Cerri \& Volkoff, 1988). 


\subsection{ESPÉCIES fORRAGEIRAs ESTUDADAS}

\subsubsection{BRACHIARIA HUMIDICDLA (RENDLE) SCHWEICKERDT}

A B. humidicola, conhecida popularmente por capim Quicuio da Amazônia é uma espécie nativa do leste e sudeste da África, onde ocorre em áreas relativamente úmidas. É uma espécie perene, com hastes floríferas com mais de $50 \mathrm{~cm}$, possuindo numerosos estolões e formando cobertura densa sobre o solo. Atinge normalmente $1 \mathrm{~m}$ de altura e os estolões são finos, de cor avermelhada, enraizando nos nós. Os rizomas apresentam-se em dois tipos: um em nódulos pequenos, compactos e outro em nódulos longos e finos, semelhantes aos estolões (Bogdan, 1977).

Apresenta ampla adaptação climática, vegetando até $2.000 \mathrm{~m}$ acima do mar. A temperatura ótima para o crescimento é de $32-35^{\circ} \mathrm{C}$. Desenvolve-se melhor em regiões tropicais úmidas (1.100 a $1.400 \mathrm{~mm}$ de chuva/ano), apesar de ter média tolerância a seca (Skerman \& Riveiros, 1992). Cresce bem em solos encharcados, mas é menos resistente do que o capim angola. É pouco exigente em fertilidade do solo, apresenta alta tolerância ao Al e baixo requerimento de fósforo (Botrel, 1990).

Apresenta boa habilidade em competir com plantas daninhas, formando pastagem bem densa, protegendo o solo contra erosão (Skerman \& Riveiros, 1992).

O capim Quicuio da Amazônia foi introduzido na região Amazônica com bastante sucesso, sendo esta sua região preferencial. É indicado para os sistemas de cria e recria de bovinos e bubalinos. Não sendo indicado para eqüinos devido aos altos teores de oxalato (Soares Filho, 1994). É o pasto mais cultivado no Estado do Pará atualmente.

\subsubsection{BRAEHIARIA MUTICA (FDRSK) STAPF}

A B. mutica é conhecida vulgarmente como capim angola, capim bengo, capim de planta, capim-do-pará. Foi inicialmente classificado como Panicum muticum (Forsk), posteriormente Panicum purpurancens (Raddi) e também Panicum barbinode (Trin). 
Considerada de origem africana, mas há quem diga ser nativa do Brasil. É uma espécie perene, apresenta bom perfilhamento e emite vigorosos estolões longos e rasteiros, que crescem rapidamente e emitem raízes na região dos nós, cobrindo o terreno em curto espaço de tempo (Pupo, 1979).

O capim angola tem habilidade de sobreviver ao encharcamento do solo, nas regiões tropicais e subtropicais, e de crescer em ambientes de água parada, ou que corre lentamente, e isto é importante para o aproveitamento de áreas pantanosas ou de várzeas de rios (Bogdan, 1977; Skerman \& Riveros, 1992).

Apresenta moderada tolerância aos solos salinos. Adapta-se melhor aos solos hidromórficos e aluviões de boa fertilidade. Apresenta baixo grau de tolerância ao sombreamento, é resistente ao ataque de cigarrinhas. Não apresenta o problema de fotossensibilização (Soares Filho, 1994).

\subsubsection{ECHINDCHLDA PYRAMIDALIS (LAM.) HITCH. \& CHASE}

A E. pyramidalis é conhecida vulgarmente como capim Mamute ou ainda por Canarana erecta lisa. Está presente em toda a África e América tropical, sendo seu habitat os pastos inundados periodicamente, margens dos lagos e rios, estando presente em altitudes de 300 a $1500 \mathrm{~m}$. Gramínea perene com porte que atinge $3 \mathrm{~m}$ de altura, raras vezes atingindo $4,5 \mathrm{~m}$, não tolera geadas, sendo resistente à seca, vegetando em baixadas onde se acumularam as águas das chuvas (Skerman \& Riveiros, 1992).

Quanto à exigência em solos está normalmente associada aos solos mal drenados com presença de argila montimorilonita de natureza aluvial, muito aderente quando úmidos e muito duros quando secos.

Nascimento \& Lourenço Junior (1979) revelaram resultados de ganho de peso em bubalinos, pastando exclusivamente $E$. pyramidalis, que permitiram a obtenção de animais pesando $450 \mathrm{~kg}$ com apenas 1,5 ano de idade. 
É tolerante à queima, produzindo rebrota muito nutritiva. É também um bom pasto para pastejo diferido. Possui boa palatabilidade, e os animais a pastejam até o nível do solo na época seca (Skerman \& Riveiros, 1992).

\subsubsection{EEHINGEHLOA PLLYSTAEHYA (H.B.K) HITCH}

A E. polystachya é conhecida vulgarmente como canarana verdadeira, canarana fluvial ou pasto alemão. É uma gramínea perene, estolonífera, que possui colmos avermelhados, suculentos (medula esponjosa), com sulco longitudinal externo característico (Mitidieri 1992). Nativa do Brasil, é muito encontrada na Bacia Amazônica, povoando terrenos alagadiços, onde vegeta com exuberância. Chega a atingir dois metros de altura, sendo muito apreciada pelo gado. É uma forrageira própria dos climas quentes e úmidos, mostrando-se muito sensível à seca e ao frio. É palatável e nutritiva (Pupo, 1979).

Vegeta muito bem em águas estagnadas, preferindo portanto as áreas mais baixas. É adaptada aos solos relativamente inférteis, mas responde vigorosamente aos fertilizantes, especialmente a adubações nitrogenadas. É bem adaptada e compete bem com Braquiária mutica onde a lâmina de água é muito funda para esta. Vegeta em profundidades de até $60 \mathrm{~cm}$. Sua propagação é realizada por intermédio de mudas, pois há pouca produção de sementes (Wildin, 1989).

Wildin (1989) citou trabalho realizado na Venezuela, onde a digestibilidade da matéria seca depois de $41,48,55$ e 62 dias foi de $63 ; 62,2 ; 59,1$ e $60,5 \%$, e a proteína bruta de 10,$3 ; 9,1 ; 8,9$ e 8,2 respectivamente.

Piedade -et-al--(1991), em trabalho sobre produtividade da gramínea $\mathrm{C}_{4} E$. polystachya em áreas inundadas da região amazônica, encontraram uma produção recorde de matéria seca de $80 \mathrm{tha}^{-1}$ em condições naturais para esta espécie e a compararam com a produtividade máxima já obtida por uma forrageira, que foi de $85 \mathrm{t}$ $\mathrm{ha}^{-1}$ para o capim elefante sob intenso manejo (Beadle et al.,1985; citado por Piedade et al., 1991). Similarmente confrontaram a produção de matéria seca por unidade interceptada de radiação solar de $2,3 \mathrm{~g} \mathrm{MJ}^{-1}$ obtido para a E. polystachya, 
comparativamente com o máximo obtido por uma espécie $\mathrm{C}_{4}$ de $2,4 \mathrm{~g} \mathrm{MJ}^{-1}$ do Pennisetum tyfhoides sob irrigação e intenso manejo (Begg, 1965; citado por Piedade et al., 1991). Concluíram que a ocorrência da E. polystachya no centro da região amazônica, é um raro exemplo de como o máximo potencial fotossintético de uma planta $\mathrm{C}_{4}$ pode ser atingido em ambientes naturais e a significância da espécie em persistir em seu habitat.

Vittori et al. (1998) avaliaram 5 espécies de forrageiras com intuito de introdução de novas espécies de capins a serem cultivados na região norte e noroeste do Estado do Rio de Janeiro. Os pastos foram submetidos a 4 cortes em diferentes idades $(14,28,42$, 56 dias), sendo que neste ensaio a $E$. polystachya se destacou apresentando um acúmulo diário de MS de $231,5 \mathrm{~kg} \mathrm{ha}^{-1}$. A produção de matéria seca total aos 56 dias foi de $11.182,4 ; 8.336,3 ; 6.971,7 ; 6.362,9 ; 5.169,5 ; 5.471,4 ; 5.248,9 \mathrm{~kg} \mathrm{ha}^{-1}$ respectivamente para as espécies E. polystachya, Hemarthria altíssima, B. arrecta, Setaria anceps, Cynodon spp (Tifiton-85), B. mutica e Acroceres macrum.

Análise química feita por Göhl (1975) revelou possuir 29,7\% de MS e 13,1\% de PB na MS. Skerman \& Riveiros (1992) citaram trabalho realizado no México com novilhos zebus, pastando E. polystachya em carga variável, onde os animais ganharam $280 \mathrm{~kg} \mathrm{ha}^{-1}$ ano.

\subsection{ACIDEZ DO SDLD}

\subsubsection{DRIGEM DA ACIDEZ DOS SLLOS}

O solo é considerado quimicamente neutro quando possui $\mathrm{pH} 7,0$. Nesta condição, é de se esperar que todas as cargas negativas do seu complexo coloidal estejam ocupadas por cátions básicos como cálcio, magnésio, potássio e sódio, os quais são constituídos por cargas elétricas positivas e portanto, ficam adsorvidos nos pontos de troca onde a carga é negativa. 
Segundo Correia (1981) na origem da acidez do solo, $\mathrm{o}^{+}$surge inicialmente da reação do $\mathrm{CO}_{2}$ do ar atmosférico com a água, além da reação de nitrificação do $\mathrm{NH}_{4}{ }^{+}$.

$$
\mathrm{CO}_{2}+\mathrm{H}_{2} \mathrm{O} \Leftrightarrow \mathrm{HCO}_{3}^{-}+\mathrm{H}^{+} \Leftrightarrow \mathrm{CO}_{3}^{-}+\mathrm{H}^{+}
$$

Essa reação acima além de liberar o íon $\mathrm{H}^{+}$, produz também o ânion bicarbonato, que possibilitará o arraste de bases em profundidade. Esta reação, entretanto, é mais importante em solos de $\mathrm{pH}$ elevado, sendo pouco expressiva em solos ácidos como os encontrados, em maior parte, no Brasil (Quaggio, 1986).

A nitrificação consiste na oxidação do nitrogênio a partir do amônio, chegando até nitrato, a qual é realizada por bactérias dos gêneros Nitrobacter e Nitrosomonas:

$$
\begin{gathered}
\mathrm{NH}_{4}^{+}+3 \mathrm{O}_{2} \Leftrightarrow 2 \mathrm{NO}_{2}^{-}+4 \mathrm{H}^{+}+\mathrm{H}_{2} \mathrm{O}+\text { energia } \\
2 \mathrm{NO}_{2}^{-}+\mathrm{O}_{2} \Leftrightarrow \mathrm{NO}_{3}^{-}
\end{gathered}
$$

$\mathrm{Na}$ aplicação de adubos amoniacais, tem-se como resultado da nitrificação o resíduo ácido. Segundo Defelipo (1990), para cada 100kg de uréia aplicada no solo são liberados $1,5 \mathrm{~kg}$ de $\mathrm{H}^{+}$e a cada $100 \mathrm{~kg}$ de sulfato de amônio liberam-se cerca de $3,0 \mathrm{~kg}$ de $\mathrm{H}^{+}$. As diferentes fontes de nitrogênio fabricadas e utilizadas como fertilizante no Brasil causam redução de $\mathrm{pH}$ do solo, onde foram aplicados, porém o efeito acidificante varia entre as fontes (Malavolta \& Neptune, 1983). Ao analisar a Tabela 1 verifica-se que o sulfato de amônio possui um poder acidificante do solo 5,35 vezes maior que o nitrocálcio, e quase 3 vezes maior que a uréia. E ainda ao considerarmos que o sulfato de amônio possui o ânion sulfato, que é responsável pelo arraste de bases no perfil do solo, seu poder acidificante se torna ainda maior.

Outro aspecto importante em solos cultivados, recebendo adubações periódicas, é a presença de ânions como sulfatos, cloretos e nitratos presentes nos fertilizantes, que após a solubilização do adubo, ficam livres na solução do solo. Estes por sua vez podem se combinar com as diversas bases presentes no solo e lixiviando-as (Quaggio, 1986). 
Tabela 1 - Características de Adubos Nitrogenados.

\begin{tabular}{lcccccc}
\hline Características & $\mathbf{U}$ & SA & NA & NCa & DAP & MAP \\
\hline$\% \mathbf{N}$ & 45 & 21 & 33 & 27 & 18 & 11 \\
\hline Índice salino* & 75,4 & 69,0 & 104,7 & 61,1 & 34,2 & 29,9 \\
\hline Acidez eq. $^{* *}$ & 1,80 & 5,35 & 1,80 & 1,00 & 3,50 & 6,0 \\
\hline
\end{tabular}

Fonte: Malavolta \& Neptune (1983). U-Uréia; SA-Sulfato de amônio; NA- Nitrato de amônio; Nca-Nitrocálcio; DAP-Fosfato diamônico MAP-Fosfato monoamônico. *- Relativo ao $\mathrm{NaNO}_{3}$

$=100{ }^{* *}$-Acidez equivalente $\left(\mathrm{Kg}\right.$ de $\left.\mathrm{CaCo}_{3} / \mathrm{Kg} \mathrm{N}\right)$.

Portanto, outro aspecto que merece destaque no processo de acidificação dos solos, consiste na remoção dos cátions para camadas mais profundas no perfil do solo, ou mesmo, até encontrarem o lençol freático. Para isso ser possível, torna-se necessário a introdução de íons que possuam o mesmo sinal das cargas das partículas do solo, designados de co-íons (ânions), os quais têm facilidade de movimento através de um fluxo descendente de água. Nesta situação, os ânions ligam-se aos cátions presentes na solução do solo, neutralizando-se mutuamente as cargas, tornando possível então o movimento dos cátions, que até então possuíam cargas positivas (não se movimentando devido à atração exercida pelas partículas do solo), e agora possuindo cargas nulas, já que se ligaram aos ânions, podem ser lixiviados (Quaggio, 1986).

Na Tabela 2 pode-se visualizar o efeito da adubação nitrogenada com sulfato de amônio, em um solo cultivado com grama bermuda recebendo diferentes dosagens anuais do fertilizante, nos parâmetros pH e status de bases. Inicialmente todos os solos tinham sido corrigidos para $\mathrm{pH}$ próximo a 7.

Tabela 2- Efeito acidificante (mudanças no pH e total de bases) do sulfato de amônio aplicado em diferentes doses por um periodo de 3 anos em solo tipo "Toa Clay Loam".

\begin{tabular}{|c|c|c|c|c|c|c|}
\hline \multirow{2}{*}{$\begin{array}{l}\text { Profund. } \\
\text { (cm) }\end{array}$} & \multicolumn{2}{|r|}{$0 \mathrm{~kg} \mathrm{ha}^{-1} \mathrm{de} N$} & \multicolumn{2}{|c|}{$800 \mathrm{~kg} \mathrm{ha}^{-1}$ de N } & \multicolumn{2}{|c|}{$3600 \mathrm{~kg} \mathrm{ha}^{-1}$ de N } \\
\hline & $\mathrm{pH}$ & bases $\left(\mathrm{mmlo}_{\mathrm{c}} \mathrm{dm}^{-3}\right)$ & $\mathrm{pH}$ & bases $\left(\mathrm{mmlo}_{\mathrm{c}} \mathrm{dm}^{-3}\right)$ & $\mathrm{pH}$ & bases $\left(\mathrm{mmlo}_{c} \mathrm{dm}^{-3}\right)$ \\
\hline $00-15$ & 7,0 & 219 & 4,1 & 115 & 3,6 & 40 \\
\hline $15-30$ & 6,1 & 206 & 5,0 & 175 & 4,2 & 90 \\
\hline $30-45$ & 5,6 & 177 & 5,2 & 177 & 4,3 & 119 \\
\hline $45-60$ & 5,6 & 183 & 5,6 & 175 & 4,8 & 162 \\
\hline $60-90$ & 5,9 & 214 & 5,9 & 211 & 5,9 & 198 \\
\hline $90-120$ & 6,1 & 211 & 6,0 & 204 & 5,9 & 204 \\
\hline
\end{tabular}

Fonte: Abruña et al., 1958. 


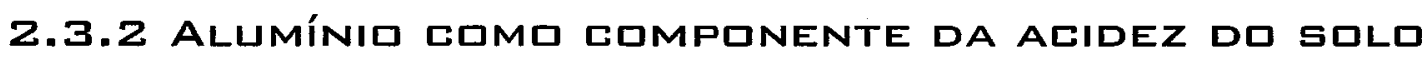

O alumínio é um elemento abundante, constituindo cerca de $15 \%$ da crosta terrestre. Sendo um importante constituinte da fração mineral do solo, que juntamente com o silício compõem os minerais de argila (minerais secundários) de grade cristalina 1:1 e 2:1, além de ocorrer adsorvido à matéria orgânica e aos próprios minerais de argila. A Tabela 3 mostra a composição química de alguns minerais de argila.

Com o processo natural ou artificial de acidificação do solo, já discutido anteriormente, a estabilidade química dos compostos de alumínio é reduzida ocorrendo aumento da solubilidade química dos minerais, de forma que parte do alumínio total torna-se solúvel, e portanto, podendo ocorrer em concentrações potencialmente tóxicas para as plantas. A atividade destes prótons faz com que o Al se desloque das lâminas das argilas tornando-se trocável ou solúvel. Portanto, à medida que os solos são lixiviados dos íons $\mathrm{Ca}^{2+}, \mathrm{Mg}^{2+}, \mathrm{K}^{+}$e $\mathrm{Na}^{+}$, e os minerais de argilas vão se solubilizando, restando

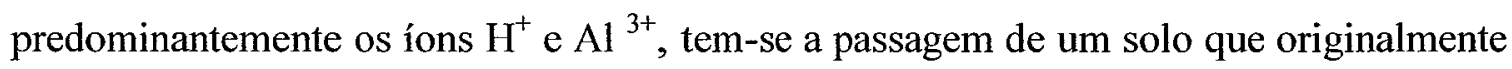
poderia ser neutro, tendo em seu complexo coloidal ocupado por bases, tornando-se ácido pela perda de suas bases e predomínio de $\mathrm{Al}$ e prótons.

Tabela 3- Constituintes de alguns minerais de argila.

\begin{tabular}{lcccc}
\hline Componentes & Caulinita & lita & Montmorilonita & Vermiculita \\
\hline $\mathrm{SiO}_{2}$ & 45,80 & 56,91 & 51,14 & 34,04 \\
\hline $\mathrm{Al}_{2} \mathrm{O}_{3}$ & 39,55 & $\mathbf{1 8 , 5 5}$ & $\mathbf{1 9 , 7 6}$ & $\mathbf{1 5 , 3 7}$ \\
\hline $\mathrm{MgO}$ & 0,14 & 2,07 & 3,22 & 22,58 \\
\hline $\mathrm{K} \mathrm{K}_{2} \mathrm{O}$ & 0,03 & 5,10 & 0,04 & 0,00 \\
\hline $\mathrm{TiO}_{2}$ & - & 0,81 & - & - \\
\hline $\mathrm{Fe}_{2} \mathrm{O}_{3}$ & 0,57 & 4,99 & 0,83 & 8,01 \\
\hline $\mathrm{FeO}$ & 0,18 & 0,26 & - & - \\
\hline $\mathrm{CaO}$ & 0,41 & 1,59 & 1,62 & 0,00 \\
\hline $\mathrm{Na}_{2} \mathrm{O}$ & - & 0,43 & 0,11 & 0,00 \\
\hline $\mathrm{H}_{2} \mathrm{O}^{+}$ & 13,92 & 5,98 & 7,99 & 19,93 \\
\hline $\mathrm{H}_{2} \mathrm{O}$ & 0,17 & 2,86 & 14,81 & - \\
\hline
\end{tabular}

Fonte: Deer et al. (1969). 
O alumínio pode ser considerado como fonte de acidez ativa, conforme pode ser visto nas reações demonstradas abaixo (Defelipo, 1990):

$$
\begin{array}{ll}
\mathrm{Al}^{3+}+\mathrm{H}_{2} \mathrm{O} \Leftrightarrow \mathrm{AlOH}^{2+}+\mathrm{H}^{+} & \mathrm{Al}^{3+}+2 \mathrm{H}_{2} \mathrm{O} \Leftrightarrow \mathrm{Al}(\mathrm{OH})_{2}^{+}+2 \mathrm{H}^{+} \\
\mathrm{Al}^{3+}+3 \mathrm{H}_{2} \mathrm{O} \Leftrightarrow \mathrm{Al}(\mathrm{OH})_{3}{ }^{0}+3 \mathrm{H}^{+} & \mathrm{Al}^{3+}+4 \mathrm{H}_{2} \mathrm{O} \Leftrightarrow \mathrm{Al}(\mathrm{OH})_{4}^{-}+4 \mathrm{H}^{+}
\end{array}
$$

Devido a este comportamento, aliado ao seu potencial tóxico para muitas plantas, o alumínio passa então a ter vital importância no estudo da acidez do solo. Tendo inclusive, seu teor na forma de íon trocável $\left(\mathrm{Al}^{3+}\right)$, utilizado por anos, e até hoje em dia em vários países do mundo e muitos estados brasileiros como elemento central para critério de cálculo de correção de solo, critério este, sugerido por Kamprath, 1970.

O comportamento do alumínio na fase líquida do solo é muito complexo, visto depender das ligações dele com radicais inorgânicos e orgânicos e do pH da solução em que se encontra (Kinraide, 1991). O fluoreto é o principal ligante inorgânico do $\mathrm{Al}^{3+}$, enquanto que os ligantes orgânicos de maior afinidade são grupos carboxila, hidroxila, carbonila, sulfato e fosfato.

Relacionando o pH de 36 amostras de solo medido em água na relação 1:2,5 com o teor de $\mathrm{Al}^{3+}$ trocável destas amostras extraídas com cloreto de potássio, Catani \& Alonso (1969) concluíram que acima de $\mathrm{pH} 5,66$ o teor de $\mathrm{Al}^{3+}$ seria nulo. Sendo a equação de regressão que obteve o referido valor foi:

\section{Meq $\mathrm{Al}^{3+} / 100 \mathrm{~cm}^{3}$ solo $=14,11-2,49 \mathrm{pH}$}

$\mathrm{Na}$ relação entre $\mathrm{Al}$ solúvel e o $\mathrm{pH}$ da solução, praticamente não ocorre $\mathrm{Al}^{3+}$ solúvel dentro da faixa de pH 5,5 a 7,0. Abaixo de pH 5,0 ocorre o Al solúvel e acima de 7,0 ocorre o íon aluminato que também é prejudicial às plantas. $\mathrm{A}$ forma $\mathrm{Al}(\mathrm{OH})^{2+}$ que predomina em solução de $\mathrm{pH}$ próximo a 4,4 é a mais prejudicial às plantas (Defelipo, 1990).

Já Kinraide (1991), em um trabalho sobre identificação de formas de alumínio rizotóxicas, descreve que muitas destas formas coexistem em solução (Figura 1) Logo, cada forma não pode ser estudada isoladamente mesmo em meios de culturas artificiais. 
Porém este autor discute os seguintes resultados sobre as formas rizotóxicas do $\mathrm{Al}$, que seriam: $\mathrm{Al}^{3+}$ (alumínio trivalente), $\left[\mathrm{AlO}_{4} \mathrm{Al}_{12}(\mathrm{OH})_{24}\left(\mathrm{H}_{2} \mathrm{O}\right)_{12}{ }^{7+}\right.$ ou $\left.\mathrm{Al}_{13}\right]$ forma polinuclear, e a forma $\mathrm{Al}(\mathrm{OH})^{2+}$ para as dicotiledônias. Comenta ainda sobre o efeito competidor do $\mathrm{H}^{+}$com o $\mathrm{Al}^{3+}$, reduzindo o efeito fitotóxico do alumínio em solução. Não obstante, Kochian (1995) alertou que a aparente toxidade das formas mononucleares hidroxiladas deveria ser considerada com cuidado, bem como a contribuição da forma $\mathrm{Al}_{13}$ na toxidade do alumínio em condições naturais.

Reconsiderando seu trabalho de 1991, Kinraide et al.(1992) concluiram que as formas hidroxiladas Al-OH não são tóxicas às plantas. Baseando-se no modelo da dupla camada difusa de Guoy-Chapman-Stern, Kinraide et al.(1992) mostram que a toxidade do Alumínio tem alta correlação com a atividade do íon na superfície da membrana plasmática e, portanto, depende da sua carga, de maneira que as formas de Alumínio tóxicas são: $\mathrm{Al}_{13}>\mathrm{Al}^{3+}>\mathrm{AlF}^{2+}>\mathrm{AlF}_{2}^{+}$.

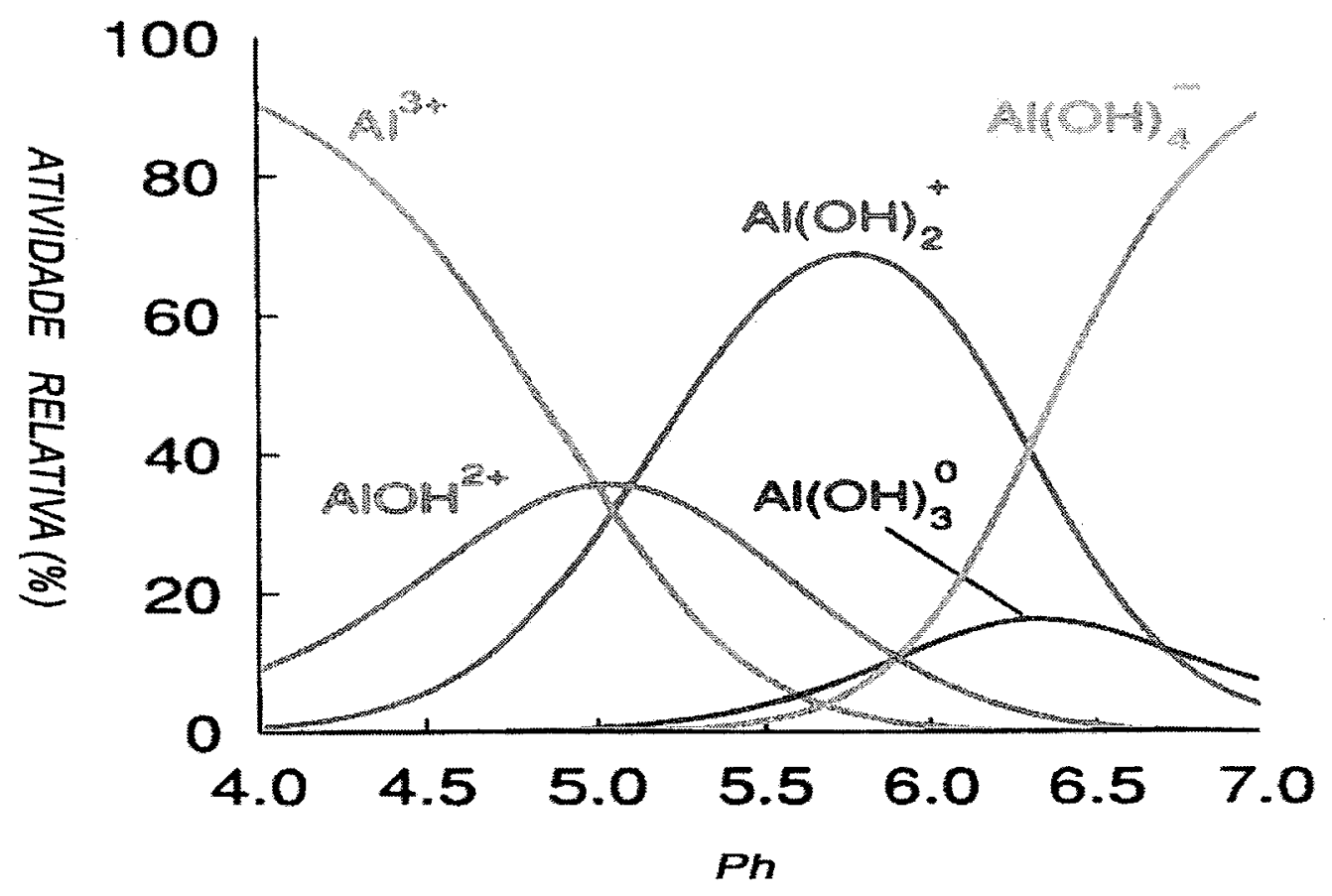

Figura 1 - Atividade relativa das formas mono-nucleares de Al (Kinraide, 1991) 
O Al solúvel, e seus óxidos hidratados ou não, estão também intimamente relacionado com a disponibilidade do fósforo, pois reagem com o $\mathrm{P}$ solúvel $\left(\mathrm{H}_{2} \mathrm{PO}_{4}{ }^{-}\right)$ tornando-o insolúvel e não disponível para as plantas (Malavolta \& Kliemann, 1985b; Tisdale et al.,1985; Raij,1991).

Como pôde ser visto, o comportamento do Al no solo e suas diversas formas em relação a potenciais tóxicos às plantas ainda são alvo de estudos recentes e portanto parecem estar longe de serem completamente elucidados.

\subsection{EFEITUS DA ACIDEZ NO SOLD}

Dos elementos componentes da acidez do solo, o $\mathrm{H}^{+}$é essencial, ou seja, as plantas necessitam dele para o seu crescimento. Já o $\mathrm{Al}$, é um elemento que em excesso é tóxico. Assim, para o estudo dos prejuízos da acidez do solo, deve-se separar os efeitos diretos, principalmente devido à acidez ativa $(\mathrm{pH})$ e os indiretos, relacionados à disponibilidade e toxidez de outros elementos minerais.

Segundo Malavolta (1985a), Arnon e Johnson (1942) desenvolveram um trabalho que foi clássico para verificar o efeito direto do $\mathrm{pH}$, onde foram utilizados o tomateiro, a alface e a grama bermuda. Os autores concluíram que em valores extremos de $\mathrm{pH}$ as plantas morreram ou apresentaram acentuada diminuição do crescimento. No pH 3,0 a absorção de macronutrientes caiu drasticamente (devido à competição com $\mathrm{H}^{+}$), havendo, em alguns casos, perdas de $\mathrm{P}, \mathrm{K}$, e $\mathrm{Mg}$. No pH 9,0 houve acentuada queda na absorção de $\mathrm{P}$ (competição com $\mathrm{OH}^{-}$). No pH 4,0 houve diminuição dos prejuízos, devido ao cálcio, pois segundo estes autores, o $\mathrm{Ca}$ estimula a absorção de $\mathrm{K}$ e, aparentemente, diminui a competição do $\mathrm{H}^{+}$com os demais cátions. $\mathrm{O}$ crescimento máximo foi verificado entre $\mathrm{pH} 6$ a 7 .

Como efeito indireto do $\mathrm{pH}$, tem-se o relacionamento da quantidade de $\mathrm{H}^{+}$ alterando a solubilidade dos demais nutrientes do solo, principalmente os micronutrientes que em demasia tornam-se tóxicos às plantas em $\mathrm{pH}$ muito baixo, mas que por outro lado em $\mathrm{pH}$ mais elevado tornam-se deficientes (Jorge, 1983). Malavolta 
et al. (1989) afirmam que de modo geral, maiores disponibilidades em relação ao $\mathrm{pH}$ estão associadas à maiores concentrações na solução do solo e finalmente maior capacidade de absorção pela planta.

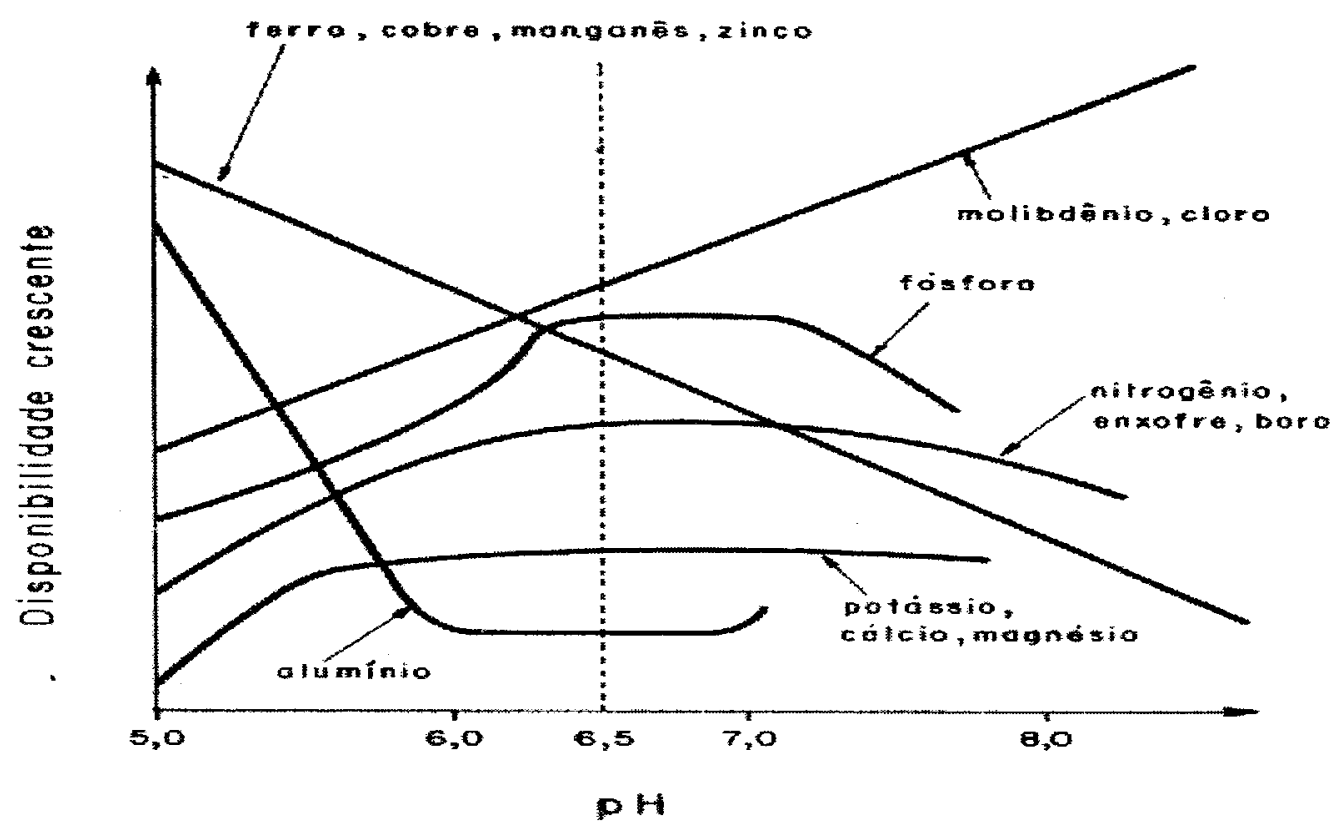

Figura 2 - Disponibilidade dos nutrientes versus pH do solo (Malavolta et al, 1989)

Jorge (1983), Malavolta et al. (1989), Defilipo (1990) e Raij (1991) mostram em suas revisões o comportamento da disponibilidade dos minerais em relação ao $\mathrm{pH}$ do solo (Figura 2), havendo porém pequenas variações no formato das curvas apresentadas por cada autor, contudo mostrando comportamentos semelhantes. No aumento de $\mathrm{pH}, \mathrm{o}$ nitrogênio é favorecido devido ao efeito favorável na amonificação e nitrificação, o enxofre pela liberação dos sulfatos que estariam ligados ao $\mathrm{Fe}$ a ao $\mathrm{Al}$, e também pelo favorecimento da decomposição da matéria orgânica. $\mathrm{O}$ cálcio, magnésio e potássio aparentemente não sofreriam nenhum efeito direto do $\mathrm{pH}$, porém, a elevação do $\mathrm{pH}$ aumenta a CTC efetiva do solo, diminuindo as perdas por lixiviação (desta forma aumentando a disponibilidade dos mesmos). Contudo, como o aumento de $\mathrm{pH}$ normalmente é conseguido pela calagem os íons $\mathrm{Ca}$ e $\mathrm{Mg}$ introduzidòs no sistema solo exercem inibição competitiva com o $\mathrm{K}$, diminuindo sua disponibilidade. $\mathrm{O}$ fósforo será 
beneficiado em sua disponibilidade até pH próximo de 6 pela liberação do $\mathrm{P}$ ligado a $\mathrm{Fe}$ e/ou $\mathrm{Al}$, porém acima deste $\mathrm{pH}$ sua disponibilidade irá reduzir novamente, agora por ligações com o $\mathrm{Ca}$. A redução da disponibilidade dos muicronutrientes catiônicos é devido à passagem das suas formas iônicas, como são absorvidos pelas plantas, para formas de óxidos ou hidróxidos.

\subsubsection{ALUMínIo VERSUS NUTRIÇÃa E ADAPTAÇÃa}

Várias pesquisas têm enfocado a interferência do Al na absorção, transporte e utilização de nutrientes, principalmente $\mathrm{Ca}, \mathrm{Mg}, \mathrm{P}$, Fe e $\mathrm{K}$ pela planta, de um modo geral reduzindo as concentrações desses nutrientes nos tecidos vegetais (Primavesi et al., 1987; Foy, 1984 e Bergmann, 1992). Esses autores concluem ainda que a capacidade dos genótipos em tolerar altas concentrações de Al está associada à sua habilidade em melhor absorver e utilizar esses nutrientes.

No caso do fósforo, para algumas plantas a resistência ao Al está relacionado ao suprimento desse nutriente, de forma que a adição de fosfato resulta no desaparecimento dos efeitos negativos. Analisando as concentrações de $\mathrm{P}$ na parte aérea e no sistema radicular de plantas de trigo tratadas com Al, Foy et al. (1965) verificaram que o cultivar sensível acumulou menos fósforo na parte aérea do que o cultivar tolerante. Provavelmente essa resposta seja decorrente da formação de complexos de $\mathrm{P}$ e Al que precipitam no interior das raízes (Silva, 1997). De um modo geral, o Al aumenta a concentração de $\mathrm{P}$ nas raízes e diminui na parte aérea (Foy, 1984).

A fosfatase ácida é uma enzima cuja atividade aumenta em condições de deficiência de $\mathrm{P}$ em várias espécies vegetais, já que a síntese desta enzima está inibida na presença de íon fosfato em mecanismo de retroinibição. Tratando-se de plantas tolerantes ao Al, Zaine \& Mercado (1985), citados por Silva (1997), postularam que o cultivar de arroz IAC-3 tinha elevada atividade da fosfatase ácida no sistema radicular, a qual hidroliza compostos orgânicos ricos em fósforo liberando fosfato inorgânico para a célula, desta forma impedindo o surgimento de deficiência do $\mathrm{P}$ induzida pelo $\mathrm{Al}$. 
O caráter tolerância pode ser controlado por diferentes genes agindo por diversos caminhos bioquímicos nas várias espécies de plantas (Foy, 1984). Os mecanismos possivelmente relacionados à tolerância ao $\mathrm{Al}$ foram classificados por Foy (1988) em dois tipos distintos: (1) Mecanismos de exclusão: imobilização de Al na parede celular; permeabilidade seletiva da membrana plasmática; barreira de $\mathrm{pH}$ induzida na rizosfera; exsudação de compostos quelantes e (2) Mecanismos de tolerância interna: complexação ou quelatização no citoplasma; compartimentação no vacúolo; proteínas especializadas na ligação com alumínio e evolução de enzimas tolerantes ao Al.

Nas plantas tolerantes, a capacidade de exclusão ou inativação do Al nos locais de sensibilidade (citoplasma, interface entre o apoplasma e a membrana plasmática, apoplasma e células do ápice radicular) tem sido especulada como mecanismo eficiente. Em plantas de trigo observou-se a formação de proteínas específicas com capacidade para inativar o $\mathrm{Al}$ (Marschner, 1985).

Variedades de cevada resistentes ao Al apresentam maior resistência à desestruturação de suas membranas, o que de acordo com Horst et al. (1997) está associado a maior quantidade de mucigel produzido pelas raízes dessas variedades, impedindo a absorção do Al.

Alguns cultivares de trigo, cevada, arroz, ervilha e milho tolerantes ao alumínio, aumentam o pH da solução nutritiva onde crescem, reduzindo a solubilidade e toxicidade do Al por precipitação. Em trigo evidências sugerem que essas mudanças de pH na rizosfera estão associadas a diferenças na capacidade da planta em absorver cátions ou ânions (Foy, 1984).

Plantas mais eficientes na absorção e utilização do nitrato $\left(\mathrm{NO}^{3-}\right)$ quando em presença de amônio $\left(\mathrm{NH}_{4}{ }^{+}\right.$, que é a forma predominante do nitrogênio em solos ácidos), promovem o aumento do $\mathrm{pH}$ na rizosfera, pois ao absorverem $\mathrm{NO}_{3}{ }^{-}$liberam $\mathrm{OH}^{-}$. Isto foi observado em plantas de trigo por Foy \& Fleming (1982). Nesse estudo constatou-se também que os genótipos tolerantes ao excesso de Al exibem elevada atividade da enzima redutase do nitrato (primeira enzima envolvida na assimilação de nitrato pelas plantas) em relação aos genótipos sensíveis, independente da presença de alumínio. 
Juntamente com o $\mathrm{N}$, outros nutrientes como $\mathrm{K}, \mathrm{Mg}, \mathrm{Ca}, \mathrm{P}$ e Fe contribuem para o balanço da absorção de nutrientes e liberação de ions $\mathrm{H}^{+}$e $\mathrm{OH}^{-}$pelas raízes. No entanto, estudos com cultivares de sorgo, diferindo em susceptibilidade a Al, sob condições de estresse desse elemento, mostraram que cerca de $89 \%$ da liberação de prótons está relacionada com a forma de nitrogênio absorvida pela planta, confirmando o papel dominante do N sob condições de estresse de Al (Tan \& Keltjens, 1995).

Excreção de ácidos orgânicos que quelatam o Al na rizosfera tem sido descrito como possível mecanismo de tolerância de certas espécies e cultivares de plantas. $O$ termo quelato vem do idioma alemão, tendo o significado de pinça. No processo da quelação as moléculas orgânicas envolvem o átomo em questão mantendo-o inativo em geral aprisionado em um anel benzênico. Ácidos orgânicos como o ácido cítrico, ácido málico e também certos polipeptídeos exsudados pelas raízes parecem agir na desintoxicação de Al pela sua quelação no apoplasma das raízes e na rizosfera (Keltjens \& Tan, 1993).

A colonização de raízes com micorrizas é outro importante componente na adaptação de plantas a solos ácidos com altas concentrações de $\mathrm{Al}$ e baixos níveis de $\mathrm{P}$ (Marschner, 1985). O efeito benéfico na aquisição de fósforo pelos fungos micorrízicos em plantas tem sido demonstrado freqüentemente, particularmente sob condições de restrita disponibilidade do elemento no solo, conseqüentemente pode-se esperar que espécies de plantas ou cultivares que são facilmente infectados por micorrizas eficientes sejam menos suscetíveis à acidez do solo do que plantas que não apresentem este tipo de simbiose (Keltjens \& Tan, 1993).

A dependência de plantas que crescem em solos tropicais com níveis tóxicos de Al pelas micorrizas é observada em muitas espécies cultivadas nos trópicos como é o caso da pastagem Stylosanthes guianensis. A proteção das raízes contra a ação destrutiva do Al pode ser explicada pelo efeito benéfico das micorrizas (Marschner,1985).

Enfim, existem muitos mecanismos químicos, bioquímicos ou associativos que muitas espécies vegetais incorporaram durante seu processo evolutivo e que as confere capacidade de se desenvolver e produzir mesmo em condições ditas desfavoráveis para 
muitas outras espécies. Segundo Raij (1991) a identificação e estudo destas espécies e/ou cultivares que tolerem condições ditas adversas é assunto que merece atenção, pois tais espécies podem ser cultivadas em locais, onde a calagem é uma prática muito cara ou até mesmo inviável, ou ainda em regiões que possuam subsolo ácidos e portanto de difícil correção.

\subsection{CIRREÇÃI DA ACIDEZ DO SLLO}

A calagem é uma prática agrícola muito antiga, usada inclusive pelos romanos. Entretanto, a sua recomendação, principalmente com base na análise de solo, tem sido até hoje motivo de muita controvérsia nos meios científicos.

No Brasil, antes de 1965, os métodos de recomendação de calagem usados na prática eram quase sempre baseados no pH e no teor de matéria orgânica dos solos, após 1965, com a divulgação do critério do alumínio trocável por Coleman et al. (1958) e Kamprath (1970) a recomendação de calagem passou a ser feita por esse critério na maioria dos estados brasileiros, com exceção dos Estados do Rio Grande do Sul e Santa Catarina que optaram pelo método SMP (Quaggio, 1986). Atualmente no Estado de São Paulo, o critério do alumínio trocável foi substituído pelo método baseado na elevação da saturação por bases do solo.

\subsubsection{MÉTODO DA INCUBAÇÃ̃}

Este método é baseado em curvas de titulação potenciométricas, sendo muito importante por ser um método considerado padrão e utilizado para calibrar os métodos rápidos. Tendo como princípio incubar amostras de solos com doses crescentes de corretivo. Após certo período de incubação o pH é determinado nas amostras incubadas e obtêm-se as curvas de neutralização dos solos, das quais a necessidade de calagem pode ser obtida para qualquer valor de $\mathrm{pH}$ desejado. Um fator importante que deve ser observado no o uso desse método, é o acúmulo de sais, oriundos da mineralização da matéria orgânica que ocorre durante o período de incubação, e que normalmente 
deprime os valores de pH em água. Este método é considerado como padrão para se verificar a eficiência dos outros métodos (Defilipo, 1990; Raij, 1991).

\subsubsection{MÉTDDO BASEADI NA ELEVAÇÃ̃ DE SATURAÇÃ̃ POR BASES}

Para determinação da quantidade de calcário segundo este método é necessário determinar os valores da soma das bases (cálcio, magnésio potássio e, em alguns casos, sódio) além dos teores de $\mathrm{H}+\mathrm{Al}$, para obtenção da CTC do solo em questão.

Neste método a determinação de calagem preconiza a elevação da saturação em bases a valores pré-estabelecidos para diferentes culturas. A fórmula para cálculo é (Quaggio et al., 1985).

$$
\begin{aligned}
& \mathbf{N C}=\left(\mathbf{V}_{2}-\mathbf{V}_{1}\right) \text { CTC } \quad \begin{array}{l}
\text { Onde: } \\
\text { NC }=\text { t de calcário/ha }(P R N T=100 \%) ;
\end{array} \\
& 100 \text { alcançar no solo; } \\
& V_{1}=\text { saturação de bases existente no solo; } \\
& \mathbf{C T C}=\text { capacidade de trocas de cátions. }
\end{aligned}
$$

Raij et al. (1983) comparando este método com o método do alumínio trocável, observaram que a diminuição do alumínio trocável não apresentou uma relação linear com a produção, a qual continuou a aumentar mesmo quando o alumínio praticamente não ocorreu. Os valores de saturação em bases, por outro lado, refletiram melhor o efeito da calagem na produção das culturas.

Revisando trabalhos sobre calagem em plantas forrageiras que tiveram como critério de correção o método de saturação por bases, observou-se que os tratamentos que tinham por meta atingir valores de V\% acima de 50 , os diversos autores não conseguiram os resultados preconizados após a incubação do solo. E quanto maiores foram os valores pretendidos de $\mathrm{V} \%$, maiores foram as diferenças entre os resultados preconizados e os alcançados efetivamente (Tabela 4). 
Tabela 4 - Resultados de vários experimentos relacionando saturações por bases desejadas e aqueles realmente atingidos após incubação do corretivo.

\begin{tabular}{|c|c|c|c|c|c|}
\hline Autor & Tipo de solo & $\begin{array}{c}\text { V\% } \\
\text { original }\end{array}$ & $\begin{array}{c}\mathbf{V}_{\mathbf{2}} \% \\
\text { desejado }\end{array}$ & $\begin{array}{l}\mathbf{V}_{\mathbf{2}} \% \\
\text { atingido }\end{array}$ & Diferença \\
\hline \multirow[t]{4}{*}{ Paulino, 1990} & \multirow{2}{*}{$\begin{array}{l}\text { Latossolo vermelho } \\
\text { amarelo distrófico }\end{array}$} & \multirow{2}{*}{22} & 35 & 35 & 0 \\
\hline & & & 70 & 59 & -11 \\
\hline & \multirow{2}{*}{$\begin{array}{l}\text { Latossolo vermelho } \\
\text { amarelo álico }\end{array}$} & \multirow{2}{*}{19} & 35 & 30 & -5 \\
\hline & & & 70 & 56 & -14 \\
\hline \multirow[t]{3}{*}{ Premazzi, 1991} & \multirow{3}{*}{$\begin{array}{l}\text { Latossolo vermelho } \\
\text { amarelo distrófico }\end{array}$} & \multirow{3}{*}{13} & 30 & 29 & -1 \\
\hline & & & 50 & 43 & -7 \\
\hline & & & 70 & 56 & -14 \\
\hline \multirow[t]{2}{*}{ Rodrigues, 1992} & \multirow{2}{*}{$\begin{array}{l}\text { Latossolo variação } \\
\text { Una }\end{array}$} & \multirow{2}{*}{13} & $50^{*}$ & 42 & -8 \\
\hline & & & $50^{* \star}$ & 40 & -10 \\
\hline \multirow[t]{2}{*}{ Colozza, 1993} & \multirow{2}{*}{$\begin{array}{l}\text { Latossolo vermelho } \\
\text { amarelo distrófico }\end{array}$} & \multirow{2}{*}{10} & 35 & 29 & -6 \\
\hline & & & 60 & 47 & -13 \\
\hline \multirow[t]{3}{*}{ Sutton, 1993} & \multirow{3}{*}{$\begin{array}{l}\text { Latossolo vermelho } \\
\text { amarelo argiloso }\end{array}$} & \multirow{3}{*}{45} & 60 & 56 & -4 \\
\hline & & & 75 & 61 & -14 \\
\hline & & & 90 & 70 & -20 \\
\hline \multirow[t]{3}{*}{ Mitidieri, 1995} & \multirow{3}{*}{$\begin{array}{l}\text { Latossolo vermelho } \\
\text { escuro álico } \\
\text { argiloso }\end{array}$} & \multirow{3}{*}{10} & 30 & 38 & +8 \\
\hline & & & 50 & 55 & +5 \\
\hline & & & 70 & 66 & -4 \\
\hline \multirow[t]{3}{*}{ Rossi, 1995} & \multirow{3}{*}{$\begin{array}{l}\text { Latossolo variação } \\
\text { Una }\end{array}$} & \multirow{3}{*}{19} & 35 & 34 & -1 \\
\hline & & & 50 & 45 & -5 \\
\hline & & & 80 & 80 & -23 \\
\hline
\end{tabular}

*- Uso de Calcário calcítico **-Uso de calcário dolomítico.

Uma possível tentativa de explicação para o não sucesso em se atingir a exata saturação desejada, pode ser devido ao método pelo qual a CTC do solo é determinada [forma indireta pela soma das bases mais acidez potencial $(\mathrm{H}+\mathrm{Al})$ ], o que acaba por acumular os erros das diversas determinações. Ou mais precisamente, o erro pode estar especificamente na determinação da acidez potencial que pode estar superestimada para valores próximos à neutralidade do solo, ou ainda por utilizar-se uma única equação para todos os tipos de solo, equação esta determinada por Quaggio et al.(1985).

\subsubsection{PrINCÍPIO DA CORREÇÃ̃ DA ACIDEZ DO SLLO}

A correção da acidez do solo, ou princípio da calagem, baseia-se na troca iônica (capacidade que possui o solo, quando em presença de um sal, reagir com este e trocar 
cátions entre si). Segundo Defilipo (1990), apesar de muitos materiais terem a capacidade de permutarem com o solo seus cátions, para ser considerado um corretivo, o material deverá possuir certos requisitos: Efetuar a reação: $\mathrm{o} \mathrm{H}^{+}$pode estar retido no solo com uma força tal, que não permita que este seja trocado com o sal. Portanto o corretivo deverá apresentar o poder de efetuar a troca; Produto da reação: uma vez efetuada a troca e o corretivo recebendo $\mathrm{o}^{+}$deverá formar um composto que não seja tóxico e/ou danoso às culturas. Ou seja, o composto resultante deverá ser um produto inerte ou solúvel que possa ser lixiviado com a água; Elemento essencial: o corretivo fornece à micela do solo um cátion e este deve ser um elemento essencial às plantas. Assim além de corrigir a acidez estará fertilizando o solo.

As rochas calcárias moídas finamente são materiais que satisfazem a maioria dos requisitos exigidos para um corretivo, ou seja, fornecem $\mathrm{Ca}$ e $\mathrm{Mg}$ como nutrientes; e sendo carbonatos, o resultado da reação são os bicarbonatos, que são solúveis e podem ser lixiviados.

$\mathrm{O}$ calcário é formado de um ácido fraco e uma base forte. Deste modo o $\mathrm{CO}_{3}{ }^{2-}$ reage com a água originando oxidrilas e estas vão reagir com o $\mathrm{Al}$ precipitando-o ou ainda com o $\mathrm{H}^{+}$formando água (Figura 3). Porém, caso fosse utilizado $\mathrm{CaCl}_{2}$ ou $\mathrm{CaSO}_{4}$, apesar destes fornecerem $\mathrm{Ca}$, não funcionariam como corretivo, pois não elevariam o pH do solo.

O calcário tem sido o corretivo mais freqüentemente utilizado, face sua frequiência e abundância com que ocorre na natureza. Porém outros materiais podem ser utilizados como corretivos, que são: óxido de cálcio e de magnésio (cal virgem) obtidos pela calcinação do calcário, hidróxidos de cálcio e de magnésio obtidos pela hidratação dos óxidos, calcário calcinado obtido pela calcinação parcial do calcário. Também são usados como corretivos as escórias de siderurgias, em que os componentes principais são os silicatos de $\mathrm{Ca}$ e de $\mathrm{Mg}$ e ainda apresentando teores relativamente altos de micronutrientes (De-Polli, 1988). 


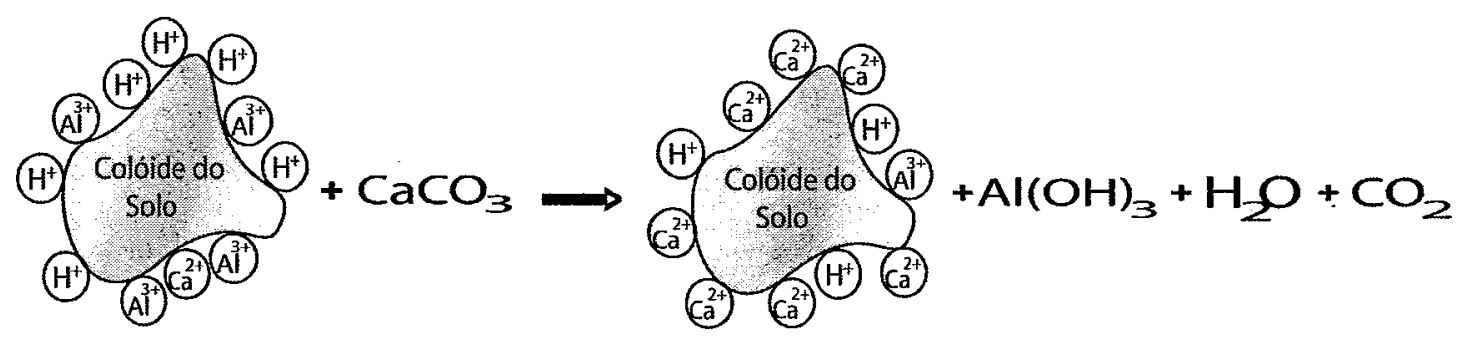

Figura 3- Representação esquemática da reação de neutralização do Al.

\subsubsection{QUALIDADE DOS CORRETIVOS}

Entre as diversas características dos corretivos relacionadas com a qualidade, duas se mostram mais importantes; a granulometria e o teor de neutralizantes, as quais vão determinar o Poder Relativo de Neutralização Total do corretivo (PRNT).

A avaliação da reatividade (RE) dos calcários é obtida levando-se em consideração sua composição granulométrica, ou seja, sua característica física. A avaliação do teor de neutralizantes é feita pela determinação do Poder de Neutralização (PN), expresso em equivalentes de $\mathrm{CaCO}_{3}$. Além destas duas características do corretivo, estes podem ainda possuir uma classificação conforme seu teor de $\mathrm{MgO}$, sendo calcítico quando possuir menos que 5\%, magnesiano de $5-12 \%$ e dolomítico quando conter mais de 12\% de $\mathrm{MgO}$ (Lopes \& Guimarães, 1989).

$\mathrm{O}$ poder neutralizante diz respeito à constituição química do calcário. $\mathrm{O} P \mathrm{PN}$ de um corretivo é definido tomando como padrão o $\mathrm{CaCO}_{3}$ puro que tem $\mathrm{PN}$ fixado em 100\%. Ou seja, 100 unidades de um corretivo com $\mathrm{PN}=70 \%$ possuem a mesma capacidade neutralizante de acidez que 70 unidades de $\mathrm{CaCO}_{3}$ (Defelipo, 1990).

Sabendo-se que 1 equivalente de carbonato de cálcio $(\mathrm{PN}=100)$ possui o mesmo efeito neutralizante que 1 equivalente de carbonato de magnésio, hidróxido de cálcio ou magnésio e óxido de cálcio ou magnésio, ou seja, estes todos neutralizam dois $\mathrm{H}^{+}$ (Figura 4). O PN destes compostos em relação ao carbonato de cálcio leva em consideração seus pesos moleculares. Como por exemplo, o $\mathrm{CaO}$ e o $\mathrm{MgO}$ possuem $\mathrm{PN}$ igual a 178,6 e $248,1 \%$, respectivamente. 

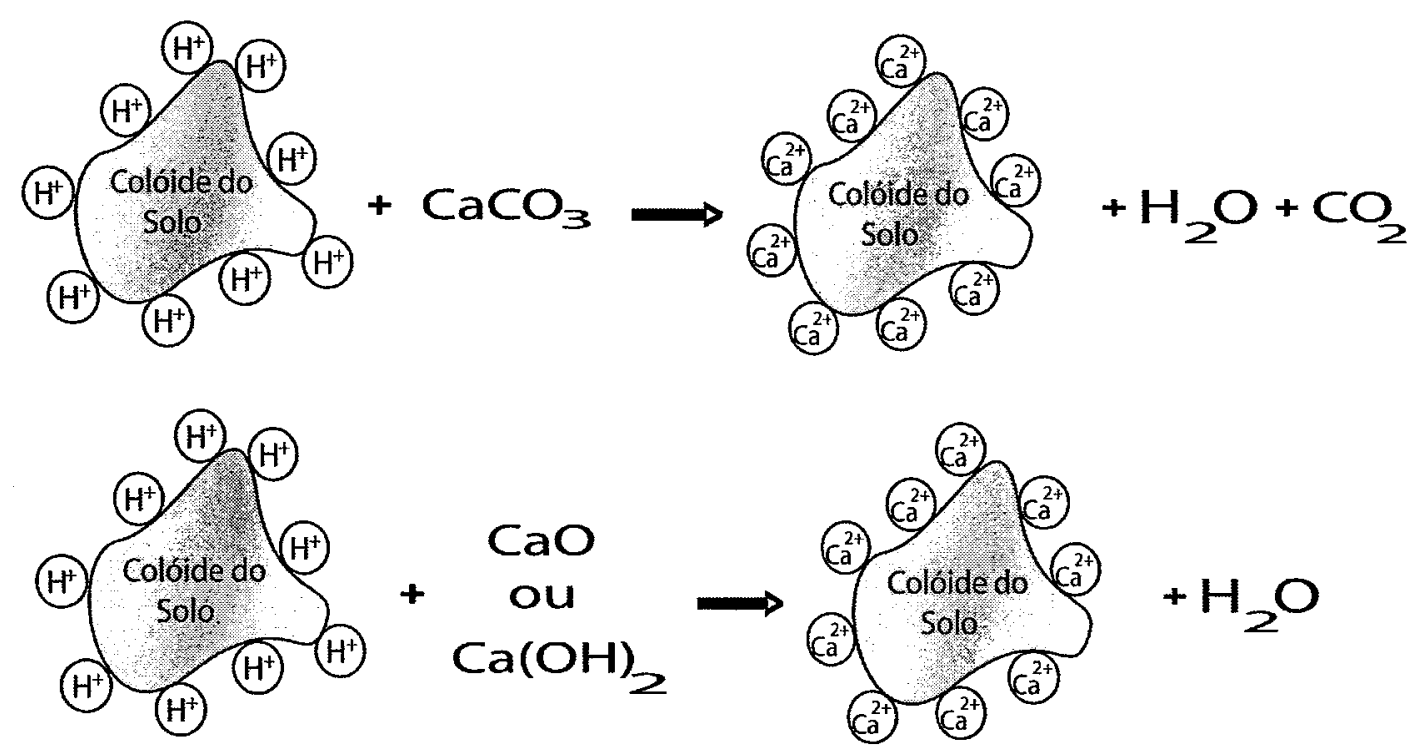

Figura 4- Representação esquemática da reação de neutralização do $\mathrm{H}$ com diferentes fontes nutralizantes: carbonatos, Óxidos e hidróxidos.

Outro fator que deve ser considerado na troca iônica entre colóides do solo e os corretivos e/ou adubos, em se tratando de interações eletrostáticas, e a afinidade de ligação de cátion que está de acordo com a série lipotrópica a seguir:

$$
\mathrm{Al}^{3+}>\mathrm{H}^{+}>\mathrm{Ca}^{2+}>\mathrm{Mg}^{2+}>\mathrm{K}=\mathrm{NH}^{+}>\mathrm{Na}^{+}
$$

Na série lipotrópica o Al tem a maior afinidade e o sódio a menor, sendo esta afinidade definida por fatores como a carga $(+3,+2$ ou +1$)$, que quanto maior, maior a afinidade. E também pelo tamanho relativo hidratado que quanto menor mais próximo pode estar do colóide, tendo assim maior afinidade. Contudo um íon com alta afinidade como no caso do $\mathrm{Al}^{3+}$ ou $\mathrm{H}^{+}$pode ser deslocado do colóide do solo por outro de menor afinidade como o $\mathrm{Ca}^{2+}$ vindo da calagem, desde que haja uma grande quantidade do cátion de menor afinidade, isto é possível pela ação de massa (Hopkins, 1995). 


\subsection{CÁlcio e MAgNÉsid como NUTRIENTEg}

\subsubsection{CÁlCIO}

A maioria do cálcio encontrado na planta está localizado na parede celular, na qual encontra-se ligado às pectinas, formando uma matriz gel (Jarvis, 1984; citado por Blevins, 1994). É um importante elemento no processo de divisão celular por duas razões; primeiro desempenhando função no fuso mitótico durante a divisão celular, e' segundo formando pectatos de cálcio na lamela média que irá separar as duas células filhas, dando coesão às mesmas. $\mathrm{O}$ cálcio é também requerido para a integridade física $\mathrm{e}$ funcionalidade da membrana plasmática, estando associado como segundo mensageiro de certos hormônios e a respostas de ambiente (Hopkins, 1995).

Recentes estudos sobre o metabolismo do Ca têm mostrado a importância dele como sinalizador de mudanças ambientais, modulado por combinações de Ca e proteína, como por exemplo a calmodolina (Blevins, 1994).

Os níveis de cálcio no citosol das células vegetais podem ter sua concentração drasticamente alterada devido a mudanças ambientais, tais como temperatura, luminosidade, pressão, gravidade ou ainda por ação hormonal, como ácido absícico (ABA). $O$ cálcio nestas situações funciona como segundo mensageiro para o fechamento estomático (Karp, 1996). O mecanismo como o cálcio exerce esta função pode ser visualizado na Figura 5. Neste controle do fechamento estomatal reservas de cálcio no vacúolo são de fundamental importância.

$\mathrm{O}$ cálcio é absorvido como íon bivalente $\left(\mathrm{Ca}^{2+}\right)$, chegando até as raízes através do fluxo em massa. Devido a esta importância na divisão das células, e de ser relativamente imóvel na planta (não sendo transportado pelo floema), os sintomas de deficiência de cálcio surgem nas regiões meristemáticas, causando deformidades e necrose nas folhas jovens. E em casos extremos, morte do meristema apical (Hopkins, 1995; Raij, 1991). 


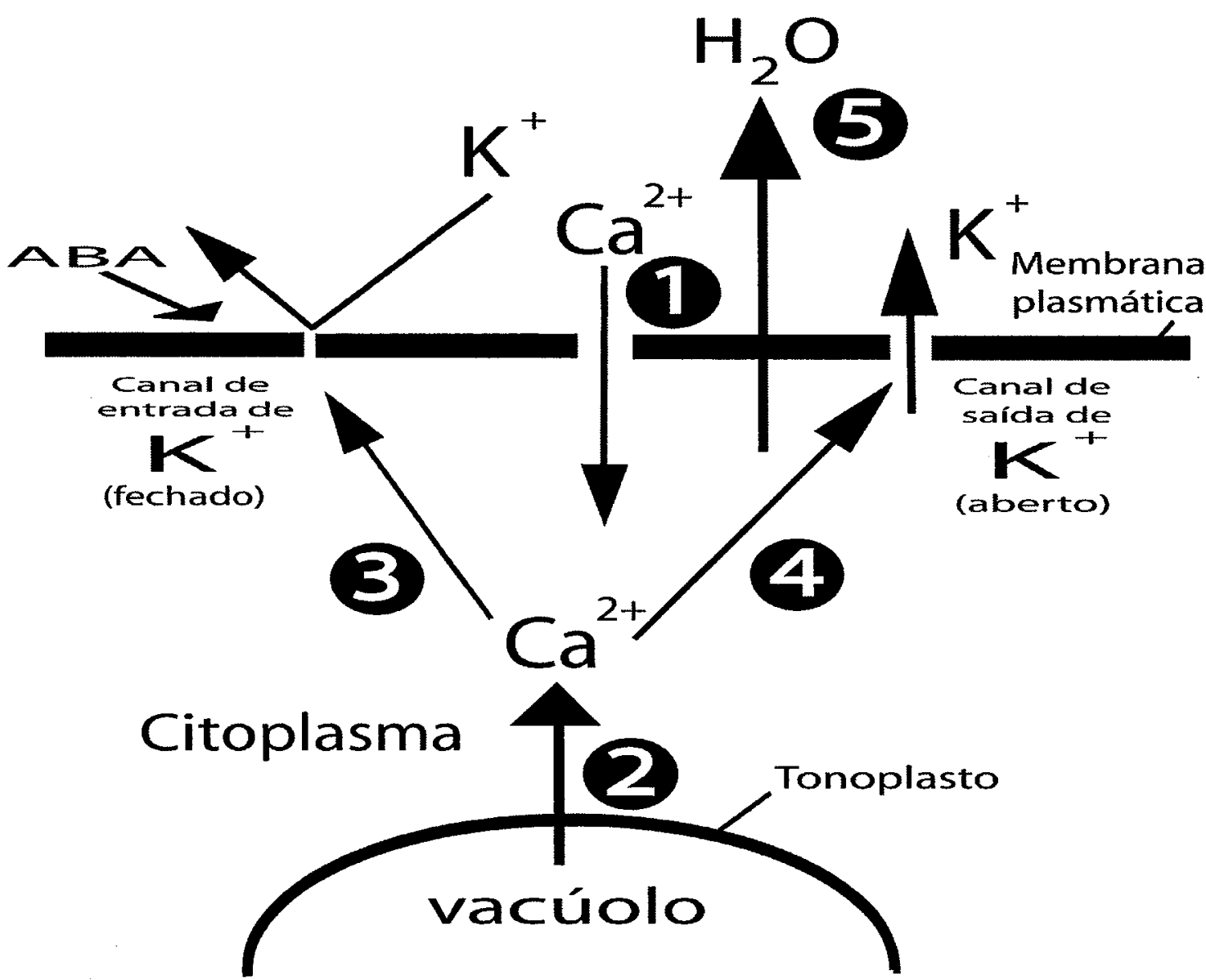

Figura 5- Representação esquemática de uma célula guarda e a participação do Ca como segundo mensageiro para o fechamento estomático em resposta à mudanças ambientais. 1por ação do $A B A$, canais de Ca são abertos dando entrada a este elemento na célula guarda. 2-O aumento de $\mathrm{Ca}$ no citosol estimula os locais de reserva (vacúolos) a liberarem mais $\mathrm{Ca}$ para o citosol. 3 e 4- $\mathrm{O}$ aumento drástico de [Ca] no citosol estimula o fechamento da entrada de $\mathrm{K}$ e concomitantemente estimula a saída de K. 5- a saida de $\mathrm{K}$ diminui a concentração de solutos na célula, o que levará a uma perda osmótica de água que causará a diminuição de turgor da célula e conseqüentemente o fechamento estomático (Karp, 1996).

\section{Z.G.Z MAGNÉSID}

O magnésio está intimamente relacionado à fotossíntese, sendo constituinte da clorofila, requerido para o empilhamento do grana, constituindo parte do complexo coletor de luz clorofila a/b, participando da ativação da Rubisco e outras reações envolvendo síntese de ATP. De 10 a 20\% do magnésio da folha está localizado nos cloroplastos, e um pouco menos que a metade deste, está ligado à clorofila. O magnésio 
também está envolvido na síntese protéica, especialmente, ligando os GTP aos ribossomos, estando também ligado à ativação da RNA polimerase. (Marschner, 1985). O magnésio parece também estar envolvido na estrutura da parede celular, durante a síntese da mesma, enquanto elas ainda estão flexíveis. Sendo posteriormente substituído pelo cálcio, o que confere rigidez às mesmas (Nakajima et al., 1981).

Blevins (1994) citando vários autores, aponta que a absorção e o metabolismo do magnésio estão intimamente ligados à absorção e ao metabolismo do fósforo, sendo o fósforo requerido para absorção do $\mathrm{Mg}$ e vice versa. Assim como o $\mathrm{Ca}$, o $\mathrm{Mg}$ também é absorvido na forma de íon bivalente $\left(\mathrm{Mg}^{2+}\right)$. Os sintomas de deficiência de magnésio geralmente estão relacionados à quebra da clorofilla nas regiões internervais das folhas, causando clorose nestes locais. Ao contrário do $\mathrm{Ca}, \mathrm{o} \mathrm{Mg}$ é relativamente móvel na planta. Em decorrência disto, a clorose provocada pela deficiência deste elemento é mais pronunciada nas folhas velhas (Hopkins, 1995; Raij, 1991).

\subsection{ESPÉcIES FORRAGEIRAS E ACIDEZ DU SLLD}

Maiores produtividades de forrageiras em solos ácidos são conseguidas pela escolha de plantas adaptadas as condições de altas concentrações de alumínio solúvel, ou pela correção da acidez do solo, quando a espécie escolhida for sensível a acidez (Siqueira, 1986). Segundo Spain \& Andrew (1976), há uma tolerância diferencial à acidez do solo entre as forrageiras.

\subsubsection{EFEITLS NA PRODUÇ̃̃̃ dE MATÉRIA SECA}

A grande maioria dos trabalhos disponíveis na literatura estudando os efeitos da calagem na produção de plantas forrageiras tropicais mostra pequeno efeito desta prática agrícola em elevar a produção destas espécies vegetais, quando o pH do solo em água já se encontra acima de 5,0-5,5 e a soma de bases do solo estiver em valor suficiente para 
atender as exigências da planta. Existindo inclusive resultados na literatura que mostram um efeito negativo da calagem na produção de algumas plantas forrageiras tropicais.

Siqueira (1986), citando diversos autores em sua revisão sobre o assunto, mostra que as gramíneas tropicais não respondem ou respondem muito pouco à calagem. Quando as forrageiras são tolerantes a acidez do solo elas respondem apenas com a aplicação de pequenas doses calcário, usualmente na ordem de 0,15 a $1 \mathrm{t} \mathrm{ha}^{-1}$ de $\mathrm{CaCO}_{3}$, em solos que normalmente requerem 4 a $6 \mathrm{t} \mathrm{ha}^{-1}$ para neutralizar o alumínio e elevar o pH próximo de 5,5 (Spain et al., 1975; Siqueira et al., 1980).

Humphreys (1987) aponta que a prática de calagem para estabelecimento em pastagens tropicais é muitas vezes desnecessária, citando exemplos onde, para o plantio de leguminosas não ocorreu diferença na produção de matéria seca quando foram aplicadas $2 \mathrm{t} \mathrm{ha} \mathrm{h}^{-1}$ em comparação a $200 \mathrm{~kg} \mathrm{ha}^{-1}$ aplicado no sulco de plantio; ou que aplicações de calcário apresentaram o mesmo efeito que aplicação de $60 \mathrm{~g} \mathrm{ha}^{-1}$ de molibdênio na produtividade de leguminosas tropicais. Mostrando portanto no primeiro caso um efeito do calcário como fornecedor de nutrientes e no segundo caso aumentando a disponibilidade de um nutriente (Mo). Este mesmo autor cita que a aplicação de calcário em muitas situações de solos tropicais pode mostrar reduções na produção das pastagens.

Sánchez (1976), compilando trabalhos do CIAT, apresenta um trabalho onde plantas forrageiras responderam unicamente à fertilização com $\mathrm{Ca}$ e/ou $\mathrm{Mg}$, visto que apenas $150 \mathrm{~kg} \mathrm{ha}^{-1}$ de calcário foram suficientes para elevar a produção de matéria seca de 7 forrageiras tropicais. Lembrando ainda este autor que esta dosagem de calcário foi insuficiente para alterar o $\mathrm{pH}$ e nível de $\mathrm{Al}$ do solo.

Siqueira et al. (1980) realizaram um experimento com três gramíneas tropicais (M. minutiflora, B. decumbens e B. humidicula) conduzido na EMBRAPA-CNPGL, sob condições de casa de vegetação, utilizando um latossolo vermelho amarelo álico muito argiloso, avaliando-se doses crescentes de $\mathrm{CaCO}_{3}\left(0,800,1500\right.$ e $\left.4000 \mathrm{~kg} \mathrm{ha}^{-1}\right)$ juntamente com quatro doses de adubação fosfatada $\left(50,100,150\right.$ e $200 \mathrm{~kg} \mathrm{ha}^{-1}$ de $\mathrm{P}_{2} \mathrm{O}_{5}$ ). Os autores verificaram que somente até a dose de $800 \mathrm{~kg} \mathrm{ha}^{-1}$ de $\mathrm{CaCO}_{3}$ houve 
aumento significativo na produção de matéria seca, citando ainda que o solo deste tratamento apresentava $\mathrm{Ca}^{2+}$ ao nível de $7,5 \mathrm{mmol}_{\mathrm{c}} \mathrm{dm}^{-3}$, e que a saturação de $\mathrm{Al}$ situouse em $42 \%$. Observando os gráficos apresentados no mesmo trabalho, verificou-se que a adubação fosfatada se mostrou mais efetiva que a calagem em elevar a produção de matéria seca das gramíneas estudadas.

As Brachiarias, que são as principais plantas forrageiras cultivadas em nosso país nos sistemas de pastagens, são consideradas plantas tolerantes à toxidez de Al. Dentro deste enfoque Pereira (1986) mencionou que os teores crescentes de Al não afetaram o rendimento de $B$. decumbens. No entanto, diversos trabalhos consultados por este autor demonstram o efeito benéfico do calcário, mesmo em dosagens pequenas, o que leva a crer a importância do Ca e Mg como nutrientes.

A importância do $\mathrm{Mg}$ como nutriente pode ser vista no trabalho realizado por Monteiro et al. (1995), onde a omissão de $\mathrm{Mg}$ em um ensaio conduzido em casa de vegetação, do tipo subtração com $B$. brizantha $\mathrm{cv}$. Marandu, resultou em redução da produção de matéria seca, que só foi superada pelos tratamentos com omissão de $\mathrm{N}$ e $\mathrm{P}$. Sintomas visuais de deficiência de $\mathrm{Mg}$ ocorreram a partir da terceira semana após o transplante, onde as plantas apresentaram suas lâminas foliares com clorose internerval, além de mostrarem-se prostradas nas últimas semanas.

Lotero et al. (1971) relatam trabalho realizado na Colômbia em solo ácido com teores muito baixos de $\mathrm{Ca}$ e $\mathrm{K}$, e teores elevados de $\mathrm{Al}^{3+}$. Nestas condições foram avaliados os efeitos da aplicação de duas doses de calcário $\left(0\right.$ e $\left.4 \mathrm{t} \mathrm{ha}^{-1}\right)$ na produção de várias forrageiras. Sendo observados aumentos significativos na produção de matéria seca dos capins Jaraguá e Elefante, e decréscimos na produção do Pangola e Gordura. Mostrando claramente uma diferença entre as espécies forrageiras.

Em um trabalho conduzido no CIAT (1977), avaliando a produção do capim Andropogon, foram testados doses de calcário $\left(0 ; 0,5 ; 2 \mathrm{e} 6 \mathrm{tha}^{-1}\right)$ na forma de $\mathrm{CaCO}_{3}$ em solos com 10;50; 35 e 90\% de saturação por $\mathrm{Al}$, respectivamente. $\mathrm{O}$ rendimento máximo na produção desta forrageira foi obtido no tratamento sem calagem. Nesta mesma instituição de pesquisas, em trabalho avaliando interação entre aplicação de 
fósforo e calagem, o capim Andropogon apresentou boa resposta à aplicação de fósforo, sendo que a calagem surtiu efeito como fornecedora de $\mathrm{Ca}$ e $\mathrm{Mg}$.

Werner et al. (1979), avaliaram três doses de calcário $\left(0 ; 1,5\right.$ e $3,375 \mathrm{tha}^{-1} \mathrm{de}$ calcário dolomítico) sobre a produção de pastagem de capim colonião já estabelecida. A menor dosagem de calcário era o suficiente para neutralizar todo o $\mathrm{Al}$ trocável e a mais alta para elevar o $\mathrm{pH}$ do solo à 6,5. O experimento foi conduzido por três anos, sendo realizados 11 cortes neste período. $\mathrm{O}$ autor verificou reduções da produção de matéria seca $\left(6,3\right.$ e 9,0\%) para as quantidades de 1,5 e 3,375 $\mathrm{t} \mathrm{ha}^{-1}$ de calcário, respectivamente, quando comparadas ao tratamento controle no primeiro ano. No segundo ano o efeito depressivo da calagem na produção de matéria seca foi explicado por uma regressão linear. E finalmente no terceiro ano não foi observado efeito significativo da calagem.

Chew et al. (1980), estudaram o comportamento de dois cultivares de capins do gênero Panicum em solo de floresta tropical recém desmatado, sob quatro doses de calcário $\left(0 ; 3,0 ; 6,0\right.$ e $12 \mathrm{tha}^{-1}$ de calcário), observaram durante os três anos do experimento resposta quadrática das produções de matéria seca em função da calagem. No terceiro ano nenhum cultivar respondeu as doses de calcário maiores que $6,0 \mathrm{tha}^{-1}$.

Premazzi (1991) submeteu duas espécies de gramíneas forrageiras (B. brizantha cv. Marandu; Panicum maximum cv. IZ-1) a crescentes saturações por bases $(10,30,50$ e 70\%), em Latossolo vermelho-amarelo distrófico, sob condições de casa de vegetação. Os resultados demonstraram que não houve efeito na produção de matéria seca da parte aérea da Brachiaria no primeiro corte. Porém, existiu efeito no segundo corte e na produção total, sendo esta acrescida até 47 e $43 \%$ de saturação por bases, respectivamente. Já para o Panicum, houve efeito significativo da calagem em todos os cortes. O perfilhamento não foi afetado significativamente para a Brachiaria, sendo que para o Panicum houve aumento de perfilhamento até $37 \%$ de saturação por bases. É importante lembrar que estes valores de saturação por base relacionados, foram os pretendidos e não os realmente alcançados.

Mitidieri (1995) trabalhou em casa de vegetação com 5 gramíneas forrageiras (Andropogon, Brizantão, Colonião, Centenário e Vencedor) em solo de cerrado, 
avaliando crescentes saturações por bases de $10,30,50$ e $70 \%$ na produção destas gramíneas. As gramíneas apresentaram comportamentos diferenciados entre si, porém não aumentaram a produção de matéria seca com o aumento das doses de calcário, observando inclusive que a calagem teve um efeito negativo à produção de matéria seca no primeiro corte realizado. $\mathrm{O}$ autor conclui que não deve ser recomendado o uso de corretivo neste tipo de solo quando este apresentar saturação por bases acima de $30 \%$.

Os poucos trabalhos encontrados na literatura onde foram avaliados os efeitos do calcário associado a altas fertilizações em experimentos de longa duração com espécies forrageiras tropicais são aqueles realizados em Porto Rico nas décadas de 60 e 70. Sendo que Abruña et al. (1964), partindo do princípio do elevado poder residual ácido de adubações pesadas desenvolveu experimentos em dois tipos de solos, testando 3 espécies forrageiras e avaliando o efeito de doses de calcário crescentes ao longo de quatro anos de avaliação.

No primeiro experimento foi avaliada a produtividade do capim elefante vegetando em solo ácido (rico em óxido de $\mathrm{Al}$ e $\mathrm{Fe}$ ) contendo 4\% de matéria orgânica, sendo classificado pelo autor como "Catalina clay". Neste experimento foram testadas as seguintes doses de calcário calcítico $\left(0,8,16\right.$ e $\left.32 \mathrm{t} \mathrm{ha}^{-1}\right)$ no início do experimento e ainda um quinto tratamento onde a calagem foi parcelada na dose de $16 \mathrm{tha}^{-1}$, sendo metade aplicada ao início do experimento e o restante aplicado dois anos após. Foi também avaliado o efeito de calagem em cobertura ou misturadas com o solo à $15 \mathrm{~cm}$ de profundidade. A fertilização anual preconizada constituía-se de $200 \mathrm{~kg}$ de $\mathrm{P}_{2} \mathrm{O}_{5}$ na forma de superfosfato simples, $600 \mathrm{~kg}$ de $\mathrm{K}$ na forma de cloreto de potássio e $800 \mathrm{~kg}$ de $\mathrm{N}$ na forma de sulfato de amônio. Em um segundo experimento avaliou-se por cinco anos as forrageiras Napier, Pangola e Colonião cultivadas em um solo classificado como "Fajardo clay" contendo 3,2\% de matéria orgânica. As doses de calcário $(0,8,16$ e 30 t $\mathrm{ha}^{-1}$ ) utilizadas neste experimento foram todas parceladas em duas vezes, sendo a adubação utilizada de $200 \mathrm{~kg}$ de $\mathrm{P}_{2} \mathrm{O}_{5}$ aplicados ao início do experimento e dois anos após e ainda aplicações anuais de $800 \mathrm{~kg} \mathrm{ha}^{-1}$ de $\mathrm{K}$ e N. 
Os autores não verificaram diferenças significativas quanto aos efeitos da incorporação do calcário bem como do seu parcelamento no primeiro experimento. Já quanto à produção de matéria seca, estes não verificaram diferenças na produção do Napier no primeiro ano, sendo que a partir do segundo ano até o final do experimento, foi observada uma queda progressiva na produção de matéria seca dos tratamentos que não receberam ou receberam doses menores de calcário. Como neste experimento foram aplicados $6200 \mathrm{~kg}$ de formulação NPK por ano, o autor conclui que seriam necessárias 8 $\mathrm{t} \mathrm{ha}^{-1}$ ano de calcário para corrigir a acidez causada por esta adubação, ou seja $1,3 \mathrm{t}$ de calcário para cada tonelada de adubo.

No segundo experimento (média de cinco anos), o Capim elefante aumentou sua produção de matéria seca até as maiores dosagens de calcário aplicadas, já o Colonião e - Pangola responderam em produção até doses de $16 \mathrm{t} \mathrm{ha}^{-1}$, porém não diferindo significativamente da aplicação de $8 \mathrm{t} \mathrm{ha}^{-1}$. Isto demonstra a maior exigência do Napier em relação às outras espécies quanto à necessidade de calagem.

Os autores levantam as seguintes justificativas para os resultados encontrados: $\mathrm{O}$ resultado da calagem não pode ser atribuído à administração de $\mathrm{Mg}$ pelo calcário já que o mesmo só possuía traços desse elemento; a produção máxima do elefante foi obtida com pH entre 4,7 a 5,0 e quando o teor de $\mathrm{Al}^{3+}$ estava abaixo de $20 \mathrm{mmol}_{\mathrm{c}} \mathrm{dm}^{-3}$. Sendo então que a resposta do Napier à calagem no Catalina clay foi atribuída ao decréscimo do $\mathrm{Al}$ trocável já que nas parcelas que não receberam calagem as raízes sofreram deformação. E as demais gramíneas no Fajardo clay foram beneficiadas tanto das reduções do $\mathrm{Al}$ como do $\mathrm{Mn}$ nas parcelas calcariadas, considerando que este último solo era rico em $\mathrm{Mn}$.

Vicente-Chandler et al. (1959a) estudaram o efeito da adubação nitrogenada $\left(200,400,800,1200\right.$ e $2000 \mathrm{~kg} \mathrm{ha}^{-1}$, na forma de sulfato de amônio) e da freqüência de cortes (40,60 e 90 dias) na produção e composição do capim elefante durante três anos. Os autores observaram que o máximo de produção de MS foi obtido quando o intervalo entre cortes foi de 90 dias, obtendo $76,7 \mathrm{t} \mathrm{ha}^{-1}$ ano quando aplicaram $2000 \mathrm{~kg}$ de $\mathrm{N}$, porém não diferindo de $75,7 \mathrm{t} \mathrm{ha}^{-1}$ ano quando foram aplicados $800 \mathrm{~kg}$ de $\mathrm{N}$ (média 
obtida das produções do primeiro e terceiro ano). O efeito da adubação nitrogenada foi extremamente marcante na produção de matéria seca, já que nas parcelas não adubadas a produção foi de apenas $30,4 \mathrm{t} \mathrm{ha}^{-1}$ ano. $\mathrm{O}$ importante salientar neste experimento, é que apesar do solo ter inicialmente sido calcariado para atingir $\mathrm{pH} 7,0$, ao final do terceiro ano de avaliação o solo que não recebeu adubação nitrogenada manteve o mesmo pH. Porém no solo das parcelas que receberam crescentes adubações nitrogenadas observouse acidificação elevada dos mesmos (Tabela 5).

Tabela 5 - Efeitos da adubação nitrogenada no pH e estado de bases do solo após 3 anos de avaliação

\begin{tabular}{lcccccc}
\hline Prof. (cm) & \multicolumn{3}{c}{$\mathbf{p H}$} & \multicolumn{4}{c}{ Bases $\mathbf{~} \mathbf{m m o l}_{\mathbf{c}} \mathbf{d m}^{-3}$ ) } \\
\cline { 2 - 7 } & $\mathbf{0 ~ \mathbf { N } ^ { * }}$ & $\mathbf{8 0 0 N}$ & $\mathbf{1 2 0 0 N}$ & $\mathbf{0 ~ N}$ & $\mathbf{8 0 0 N}$ & $\mathbf{1 2 0 0 N}$ \\
\hline $0-15$ & 7,0 & 4,1 & 3,5 & 219 & 115 & 40 \\
\hline $15-30$ & 6,1 & 5,0 & 4,1 & 206 & 175 & 90 \\
\hline $30-45$ & 5,6 & 5,2 & 4,3 & 177 & 177 & 119 \\
\hline $45-60$ & 5,6 & 5,6 & 4,8 & 183 & 175 & 162 \\
\hline $60-75$ & 5,9 & 5,9 & 5,9 & 214 & 211 & 198 \\
\hline
\end{tabular}

Fonte: adaptado de Vicente-Chandler et al.(1959a) *- $\mathrm{kg}^{-1}$ he nitrogênio aplicados anualmente.

Como pode ser observada, a produtividade do capim Elefante manteve-se elevada mesmo com expressiva redução do pH. Porém observa-se que mesmo nas dosagens mais elevadas de $\mathrm{N}$ as quantidades de bases neste solo apresentavam-se em valores satisfatórios mostrando que o efeito do conteúdo de bases é mais determinante que o $\mathrm{pH}$ na produtividade desta forrageira.

Este mesmo grupo de pesquisadores (Vicente-Chandler et al., 1959b e VicenteChandler et al., 1959c), trabalhando dentro dessa mesma linha de pesquisas observaram comportamentos semelhantes para o Panicum maximum e para Brachiaria mutica.

De forma geral observamos, através dos resultados apresentados que o limitante a produção das forrageiras estudadas estavam mais relacionados ao teor de bases presente nos solos que ao $\mathrm{pH}$, e/ou $\mathrm{Al}^{3+}$. 


\subsubsection{EFEITI NA CLMPGSIÇÃ QUÍMICA DA FRRRAGEM}

Mitidieri (1995), em revisão sobre o assunto, aponta que os teores de minerais nas plantas variam, via de regra, com diversos fatores; dentre eles, a diferença genética entre as espécies e cultivares, o estádio de maturação fisiológica, a época do ano, a parte da planta amostrada, a mobilidade dos nutrientes na planta, a textura e fertilidade natural do solo onde a planta se encontra, o tipo e dosagem do corretivo/fertilizante utilizado e as interações entre os nutrientes no solo e na planta.

Abruña \& Figarella (1957), trabalhando em um solo ácido de Porto Rico utilizando doses de $\mathrm{P}$ e calcário, não encontraram diferenças no teor de proteína, $\mathrm{Ca}^{2+} \mathrm{e}$ P na parte aérea do Colonião nas parcelas calcariadas, mas obtiveram efeito do calcário no teor de proteína para a espécie Kudzu (Pueraria phaseoloides).

Abruña et al. (1964), em experimento já citado anteriormente, trabalhando com elevadas quantidades de fertilizante e doses crescentes de calcário calcítico em capim Napier, Colonião e Pangola encontraram resposta no aumento da percentagem de Ca e diminuição do Mn nas três gramíneas com o aumento da calagem. Não houve efeito significativo nos teores de $\mathrm{P}$ e $\mathrm{Mg}$. O Colonião apresentou maior conteúdo de $\mathrm{Ca}$ e $\mathrm{Mg}$ que os demais capins e o elefante foi o que apresentou os menores teores de $\mathrm{Mn}$.

No trabalho de Werner et al. (1979), o efeito do calcário em capim Colonião foi bem evidente no aumento dos teores de $\mathrm{Ca}$ no $3^{\circ}$ ano de condução do experimento, passando de 3,4 para $4,2 \mathrm{~g} \mathrm{~kg}^{-1}$ na MS para os tratamentos sem calagem e $3,37 \mathrm{t} \mathrm{ha}^{-1}$ do corretivo, respectivamente. A calagem não alterou os teores de $\mathrm{P}$ e proteína bruta da forragem. Sendo que os teores de potássio apresentaram tendência de diminuição no primeiro ano do ensaio, passando de $1,83 \%$ para $1,71 \%$ e no segundo ano, de $2,13 \%$ para 2,05\% diante da aplicação das doses de calcário já citadas, respectivamente.

Gomide et al. (1986), trabalhando com calagem e fontes de fósforo em solo arenoso de cerrado observaram do segundo para o terceiro ano de condução do ensaio, aumentos nos teores de Ca no capim colonião de 3,0 para $4,1 \mathrm{~g} \mathrm{~kg}^{-1}$, respectivamente. Os 
teores de $\mathrm{Mg}$ na matéria seca da gramínea subiram de 1,6 no segundo ano para $2,0 \mathrm{~g} \mathrm{~kg}^{-1}$ no terceiro ano.

Carriel et al. (1989), em experimento conduzido sob casa de vegetação com os capins Braquiaria decumbens, colonião e gordura verificaram que a omissão de calagem limitou os teores de Ca na parte aérea somente do colonião e os teores de $\mathrm{Mg}$, para todas as gramíneas. Comparando as espécies estudadas, o colonião apresentou teores mais elevados de Ca tanto na presença como na ausência de calagem, e teores mais altos de $\mathrm{Mg}$ que os outros dois capins na presença de calagem e mais baixos de $\mathrm{Mg}$ na ausência do corretivo.

Premazzi (1991), avaliou os teores de macronutrientes e micronutrientes com crescentes de saturação por bases. Para os macronutrientes constatou que somente os teores de Ca e Mg na B. brizantha foram afetados significativamente pelos tratamentos, os quais aumentaram. Enquanto para o Colonião houve resposta significativa para todos os teores de macronutrientes no primeiro corte, reduzindo $\mathrm{P}$ e $\mathrm{K}$ e aumentando $\mathrm{Ca}, \mathrm{Mg}$ e $\mathrm{S}$; no segundo corte, somente os teores de $\mathrm{P}$ e S não apresentaram efeito significativo, repetindo o comportamento para os demais minerais. Os resultados para os teores de micronutrientes mostraram que, elevações nas saturações por bases tiveram efeito significativo na redução dos teores de $\mathrm{Zn}$ e Mn para ambas as gramíneas em todos os cortes, redução de $\mathrm{Cu}$ no primeiro corte realizado, para ambas e finalmente aumento de boro para a Brachiaria no segundo corte.

Colozza (1993) estudou os efeitos da calagem e gessagem em pastagens de Colonião consorciada com Soja Perene durante quatro anos. As doses crescentes de calcário dolomítico foram responsáveis por aumentos nos teores de $\mathrm{Ca}, \mathrm{Mg}$, redução dos teores de $\mathrm{Fe}$ e $\mathrm{Mn}$ e não alteração de $\mathrm{P}, \mathrm{S}, \mathrm{B}, \mathrm{Cu}$ do Colonião. Os teores de potássio tiveram comportamento mais variável durante o experiemento reduzindo no primeiro ano, tendo um comportamento quadrático com pontos de máximo no segundo e terceiro ano e aumentando no último ano.

Mitidieri (1995) avaliou 4 saturações por bases (10, 30, 50 e 70\%) realizando dois cortes nas gramíneas: Colonião IZ-1, Vencedor, Centenário, Marandu e 
Andropogon. Analisando a composição química, para teor de $\mathrm{N}$, verificou um efeito linear crescente no $1^{\circ}$ corte das 4 primeiras gramíneas citadas e não observando efeito significativo para o Andropogon, assim como para todas as gramíneas no segundo corte. Para os teores de $\mathrm{P}$ encontrou redução linear para as 4 primeiras gramíneas no $1^{\circ}$ corte e não efeito no segundo assim como em ambos os cortes realizados para o Andropogon. Os teores de $\mathrm{K}$ não foram significativos para o Andropogon, tendo um comportamento linear crescente para os demais capins. O Ca e $\mathrm{Mg}$ também tiveram comportamento linear crescente para todos os capins com exceção do Andropogon que só demonstrou efeito para Ca no $1^{\circ}$ corte. Os teores de $\mathrm{S}$ foram na maioria das vezes não significativo, tendo um comportamento linear crescente no $1^{\circ}$ corte do Vencedor e Centenário. Quanto aos teores de micronutrientes, quando significativos, mostraram retas decrescentes para $\mathrm{Mn}$ e $\mathrm{Zn}$, retas crescentes ou quadráticas com ponto de máxima para o $\mathrm{B}$. O Fe não foi significativo na maioria das vezes tendo mostrado um efeito linear crescente para o Andropgon no segundo corte. E finalmente os teres de $\mathrm{Cu}$ se mostraram com comportamento mais variado, mostrando equações quadráticas com ponto de mínima em dois cortes (Colonião), lineares crescentes em 2 ocasiões (Centenário e Marandu) e linear decrescente em um corte (Vencedor).

Gonçalves et al. (2000) estudando o efeito de doses crescentes de calcário para o capim Andropogon verificaram aumentos significativos nos teores de $\mathrm{P}, \mathrm{Ca}$ e $\mathrm{Mg}$, e reduções nos teores de proteína bruta da forragem. Indicaram também como níveis críticos internos de cálcio e magnésio os valores de 6 e $2 \mathrm{~g} \mathrm{~kg}^{-1}$ respectivamente, para $90 \%$ da produção máxima da forrageira.

\subsubsection{DESENVLLVIMENTL DQ SISTEMA RADICULAR}

Muito se tem discutido a respeito da calagem com a função de melhorar o desenvolvimento do sistema radicular, visando o melhor aproveitamento dos nutrientes existentes no perfil do solo bem como da água, possibilitando assim maior resistência à seca devido ao sistema radicular mais profundo. $\mathrm{O}$ crescimento das raízes das culturas está intimamente relacionado ao cálcio disponível no perfil do solo (Ritchey et al., 
1983), bem como ao teor de Al tóxico. Dentro desse contexto tem-se buscado fazer incorporações de corretivos a maiores profundidades no solo bem como o uso de técnicas que utilizam substâncias que quando aplicadas aos solos promovam a lixiviação de bases a camadas mais profundas do solo visando elevar os teores de bases nestas camadas, condição necessária para que muitas espécies vegetais desenvolvam sistemas radiculares normais.

Os solos tropicais na sua maioria possuem sub-solos ácidos que restringem o desenvolvimento de raízes de espécies sensíveis. Buscando relacionar diferentes tolerâncias à toxidez de $\mathrm{Al}$ para o desenvolvimento de raízes com diferentes espécies vegetais, Brenes \& Pearson (1973) avaliaram três espécies de gramíneas. Neste trabalho os autores verificaram que a grama estrela não apresentou mudanças no desenvolvimento radicular mesmo quando vegetando em solo de $\mathrm{pH} 4,0$. Sendo que o desenvolvimento radicular do milho somente foi reduzido quando a saturação por $\mathrm{Al}$ estava acima de $50 \%$, já as saturações de $\mathrm{Al}$ acima de $80 \%$ restringiram pela metade a produção de raízes. A espécie mais sensível testada foi o sorgo, sendo que o crescimento radicular reduziu linearmente com a elevação da saturação de $\mathrm{Al}$, não apresentando crescimento radicular quando a atividade de $\mathrm{Al}$ na solução do solo foi de $0,113 \mathrm{mM}$. Este trabalho mostra claramente a diferença existente entre espécies quanto à tolerância a ambientes ácidos no que se refere ao desenvolvimento de raízes.

Goedert et al. (1985), trabalharam em um solo de textura argilosa do cerrado, avaliando o desenvolvimento do sistema radicular de capim Andropogon através da abertura de trincheiras. Observaram abundante quantidade de raízes até uma profundidade de $180 \mathrm{~cm}$, concluindo que o capim Andropogon tem capacidade de desenvolver um sistema radicular denso e profundo, mesmo em condições adversas de solo. No ensaio em casa de vegetação, testando teores crescentes de $\mathrm{Ca}(0 ; 0,1 ; 0,2 ; 0,3$; 0,4 e $0,5 \mathrm{mmol}_{\mathrm{c}} \mathrm{dm}^{-3}$ ) no solo, estes autores observaram que o crescimento radicular esteve correlacionado com o teor de $\mathrm{Ca}^{2+}$ no solo, indicando que o crescimento das raízes do Andropogon foi reduzido quando o teor de Ca trocável no solo encontrava-se menor que $0,2 \mathrm{mmol}_{\mathrm{c}} \mathrm{dm}^{-3}$. 
Premazzi (1991) também não verificou diferenças na produção de matéria seca de raízes para os capins Colonião e Brizantão quando cultivados em solo submetido a crescentes saturações por bases.

Mitidieri (1995) não verificou diferenças na produção de matéria seca de raízes para a $B$. brizantha e para 3 cultivares de $P$. maximum quando cultivados em solo submetido a crescentes saturações por bases $(10,30,50$ e 70\%), analisando por espécie, porém obtendo um efeito linear decrescente da calagem, quando a análise foi por tratamento (agrupando todas as gramíneas). Tendo verificado ainda um efeito quadrático com ponto de mínima para a produção do $A$. gayanus. 


\section{MATERIAL E MÉTDDDS}

\section{1 LocAl e perínd}

O presente experimento foi conduzido em casa-de-vegetação do Laboratório de Plantas Cultivadas sob Condições de Estresse do Departamento de Ciências Biológicas da ESALQ - Escola Superior de Agricultura "Luiz de Queiroz", situada em Piracicaba SP. Sendo realizado no período de agosto de 1999 a janeiro de 2000.

\subsection{EsPÉcIEs DE gRAMíneAs AVALIADAS}

As espécies forrageiras estudadas foram: Brachiaria mutica (Forsk) Stapf, Brachiaria humidicola (Rendle) Schweickerdt, Echinochloa pyramidalis (Lan.) Hitch. \& Chase e Echinochloa polystachya (H.B.K) Hitch.

\subsection{SRLDS UTILIZADOS}

\subsubsection{DRIGEM E CDLETA}

Os solos utilizados foram oriundos da Ilha de Marajó - PA, cujas coordenadas geográficas dos pontos de coleta estão entre $00^{\circ} 72^{\prime}-00^{\circ} 73^{\prime}$ de latitude Sul e $48^{\circ} 75^{\prime}$ - 
$48^{\circ} 74^{\prime}$ de longitude Oeste, sendo coletados entre os dias 24 e 30 de dezembro de 1998. A Figura 6 mostra o relevo e vegetação típica do local onde os solos foram coletados.

O volume total coletado de cada solo foi de aproximadamente $1500 \mathrm{~kg}$, sendo composto a partir de 30 pontos distintos de coleta, tendo cada um destes pontos, uma área de $40 \times 40 \mathrm{~cm}$ e $20 \mathrm{~cm}$ de profundidade. Após a coleta, estes foram deslocados para uma área coberta, onde permaneceram secando em cima de lonas plásticas por $48 \mathrm{~h}$. Após este período, foram peneirados, homogeneizados intensamente e finalmente acondicionados em sacos com capacidade de $30 \mathrm{Kg}$ cada. $\mathrm{O}$ volume total ensacado e enviado para São Paulo foi de aproximadamente a metade daquele que havia sido coletado no campo.

\subsubsection{CARACTERÍSTICAs físico-químicas}

Os solos, após terem chegado a Piracicaba, foram novamente homogeneizados e neste momento foram retiradas amostras para diversas análises, cujos resultados estão revelados nas Tabelas $6,7,8$ e 9 . Os solos a partir deste momento passaram a serem tratados como solo 1 e solo 2 .

Tabela 6- Análise granulométrica (valores em \%)

\begin{tabular}{lccccccccccc}
\hline \multirow{2}{*}{ Solo } & \multicolumn{9}{c}{ Areia } & \multirow{2}{*}{ Silte } & \multicolumn{2}{c}{ Argila } & \multirow{2}{*}{ Floculação } & Classe \\
\cline { 2 - 7 } & MG & G & M & F & MF & Total & & Total & Água & & \\
\hline Solo 1 & - & - & - & 21 & 29 & 50 & 38 & 12 & 6 & 50 & arenoso \\
\hline Solo 2 & - & 1 & - & 1 & 1 & 3 & 35 & 62 & 43 & 31 & muito argiloso \\
\hline MG- muito grossa; G- grossa; M- média; F- fina; MF- muito fina & & &
\end{tabular}

Tabela 7- Análise química

\begin{tabular}{|c|c|c|c|c|c|c|c|c|c|c|c|c|c|c|}
\hline \multirow{2}{*}{ Solo } & PH & $\mathbf{p H}$ & M.O & $\mathbf{P}$ & $\mathrm{S}-\mathrm{SO}_{4}$ & $\mathbf{K}$ & $\mathrm{Ca}$ & Mg & $\mathrm{Al}^{3+}$ & $\mathrm{H}+\mathrm{Al}$ & SB & CTC & \multirow{2}{*}{\multicolumn{2}{|c|}{$v_{\%}^{m}$}} \\
\hline & $\left(\mathrm{CaCl}_{2}\right)$ & $\left(\mathrm{H}_{2} \mathrm{O}\right)$ & $g d m^{-3}$ & & $\mathrm{dm}^{-3}$ & \multicolumn{7}{|c|}{$\mathrm{mmol}_{\mathrm{c}} \mathrm{dm}^{-3}$} & & \\
\hline Solo 1 & 3,78 & 4,88 & 26 & 8 & $9-$ & 3,0 & 1,2 & 2,5 & 9,59 & 51,3 & 6,7 & 58 & 11 & $\overline{59 \uparrow}$ \\
\hline Solo 2 & 4,05 & 4,77 & 34 & 2 & $40 p$ & 2,8 & $-2,5$ & 18,0 & 922,0 & 132,7 & 23,3 & 156 & 315 & 49 \\
\hline
\end{tabular}


Tabela 8- Análise de micronutrientes e sódio

\begin{tabular}{|c|c|c|c|c|c|c|}
\hline \multirow{2}{*}{ Solos } & $\mathbf{B}$ & $\mathrm{Cu}$ & $\mathrm{Fe}$ & Mn & $Z \mathbf{n}$ & $\mathrm{Na}$ \\
\hline & \multicolumn{5}{|c|}{$\mathrm{mg} \mathrm{dm}^{-3}$} & $\mathrm{mmol}_{\mathrm{c}} \mathrm{dm}^{-3}$ \\
\hline Solo 1 & $0,19 B$ & $0,5 M$ & $130,0 \mathrm{~d}$ & $15,0 \mathrm{~A}$ & 1,9 A & 1,0 \\
\hline Solo 2 & $0,25 M$ & $1,2 \mathrm{~A}$ & $91,0 A$ & 53,24 & 1,7 A & 27,0 \\
\hline
\end{tabular}

Tabela 9- Análise física - umidade (\%)

\begin{tabular}{lcccccc}
\hline Solos & \multicolumn{6}{c}{ atm } \\
\cline { 2 - 7 } & $\mathbf{0 , 0 1}$ & $\mathbf{0 , 0 5}$ & $\mathbf{0 , 1}$ & $\mathbf{0 , 3 3}$ & $\mathbf{1 , 0 0}$ & $\mathbf{1 5 , 0 0}$ \\
\hline Solo 1 & 35,50 & 33,34 & 27,62 & 22,60 & 19,30 & 18,48 \\
\hline Solo 2 & 52,67 & 49,09 & 42,00 & 37,96 & 35,97 & 35,42 \\
\hline
\end{tabular}

\subsubsection{CLASSIFICAÇÃO}

No local de coleta dos solos, para fins de classificação, foram abertas trincheiras com $80 \mathrm{~cm}$ de profundidade, as quais possibilitaram amostragens dos diversos horizontes de cada solo. As Figuras 7 e 8 mostram as trincheiras abertas. As Tabelas 10, 11 e 12 mostram os resultados das análises laboratoriais realizadas para cada solo.

Tabela 10- Análise granulométrica dos perfis dos solos (valores em \%)

\begin{tabular}{|c|c|c|c|c|c|c|c|c|c|c|c|}
\hline \multirow{2}{*}{$\begin{array}{l}\text { Prof. } \\
(\mathrm{cm})\end{array}$} & \multicolumn{6}{|c|}{ Areia } & \multirow{2}{*}{ Silte } & \multicolumn{2}{|c|}{ Argila } & \multirow{2}{*}{ Floculação } & \multirow{2}{*}{$\begin{array}{l}\text { Classe } \\
\text { textural }\end{array}$} \\
\hline & MG & G & M & $F$ & MF & Total & & Total & Água & & \\
\hline \multicolumn{12}{|c|}{ Solo 1} \\
\hline $0-5$ & - & - & 2 & 28 & 24 & 54 & 32 & 14 & - & 100 & arenoso \\
\hline 5-15 & - & - & - & 33 & 21 & 54 & 36 & 10 & 2 & 80 & arenoso \\
\hline $15-25$ & 1 & - & - & 7 & 10 & 18 & 31 & 51 & 2 & 96 & argiloso \\
\hline $25-40$ & 1 & - & - & 6 & 12 & 19 & 31 & 50 & - & 100 & argiloso \\
\hline $40-60$ & - & - & - & 25 & 22 & 47 & 20 & 33 & 16 & 52 & Médio argiloso \\
\hline $60-80$ & - & - & - & 35 & 20 & 55 & 21 & 24 & 20 & 17 & Médio arenoso \\
\hline \multicolumn{12}{|c|}{ Solo 2} \\
\hline $0-5$ & 1 & 1 & 1 & 1 & 1 & 5 & 35 & 60 & - & 100 & muito argiloso \\
\hline $5-10$ & 1 & 1 & 1 & 1 & - & 4 & 40 & 56 & - & 100 & argiloso \\
\hline $10-20$ & - & 1 & - & - & 1 & 2 & 20 & 78 & 11 & 86 & muito argiloso \\
\hline $20-35$ & 1 & - & - & - & 1 & 2 & 24 & 74 & 53 & 28 & muito argiloso \\
\hline $35-50$ & 2 & 1 & - & - & - & 3 & 19 & 78 & 42 & 46 & muito argiloso \\
\hline $50-80$ & 1 & - & - & - & 1 & 2 & 20 & 78 & 70 & 10 & muito argiloso \\
\hline
\end{tabular}




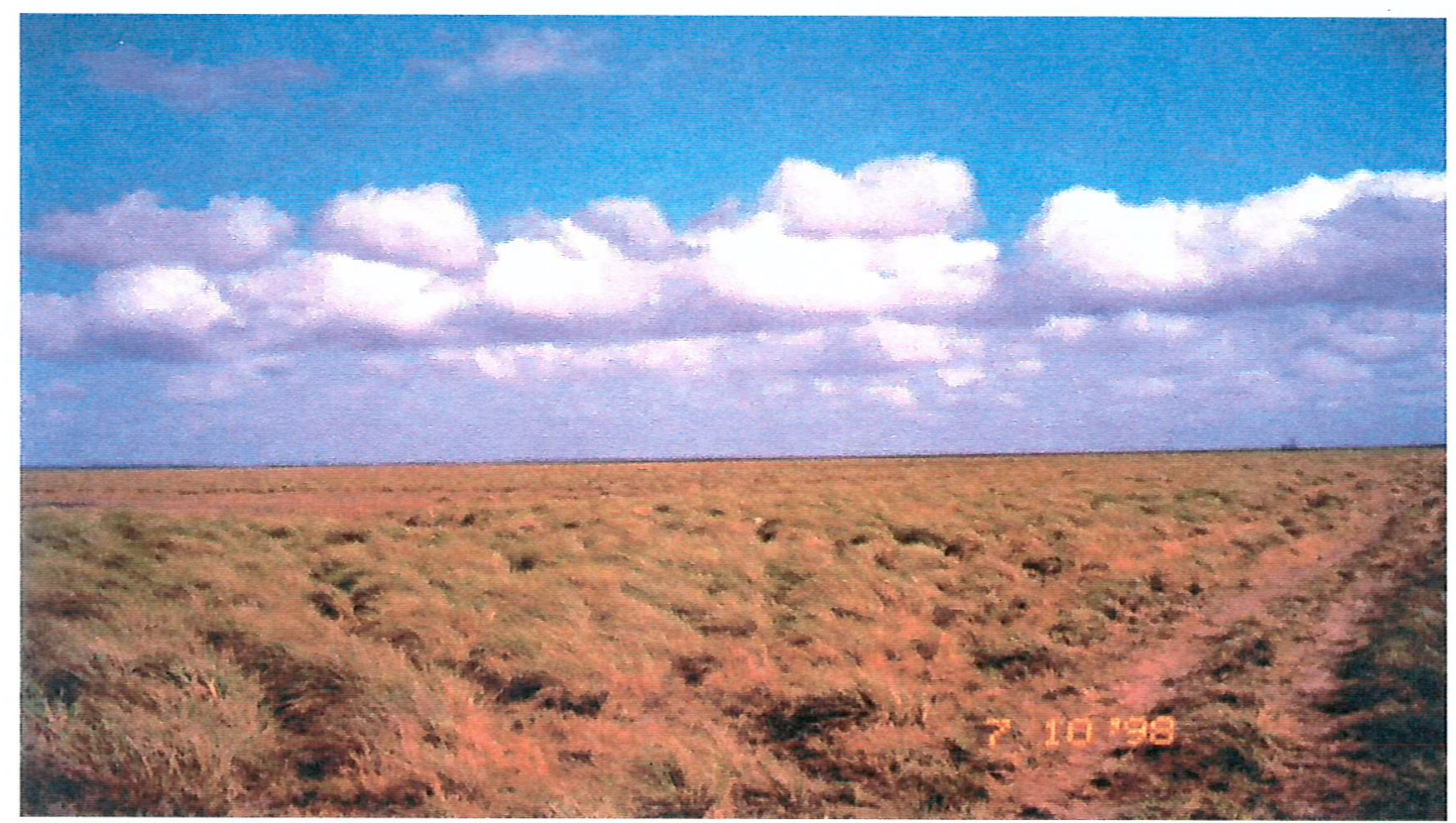

Figura 6- Local de coleta dos solos na llha de Marajó, município de Salvaterra-PA.
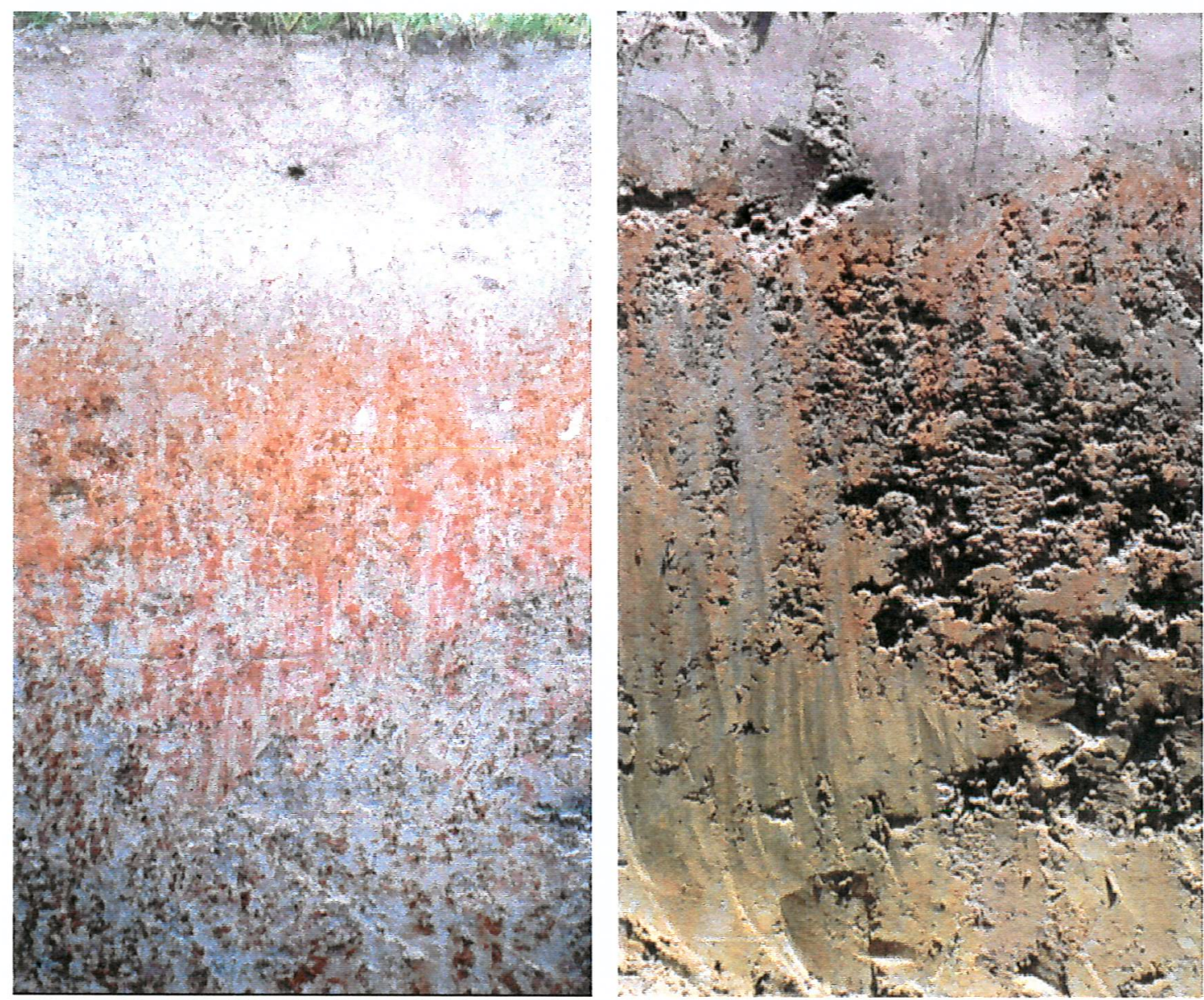

Figura 7 e 8- Trincheiras abertas ( $80 \mathrm{~cm}$ de profundidade) Solo1 à esquerda e Solo2 à direita. 
Tabela 11- Análise química dos perfis dos solos

\begin{tabular}{|c|c|c|c|c|c|c|c|c|c|c|c|c|c|c|}
\hline $\begin{array}{l}\text { Prof. } \\
\text { (cm) }\end{array}$ & $\begin{array}{l}\mathbf{p H} \\
\left(\mathrm{CaCl}_{2}\right)\end{array}$ & $\begin{array}{c}\text { pH } \\
\left(\mathrm{H}_{2} \mathrm{O}\right)\end{array}$ & $\begin{array}{l}\text { M.O } \\
\mathrm{g} \mathrm{dm}{ }^{-3}\end{array}$ & \multicolumn{2}{|c|}{$\begin{array}{c}P \quad \mathbf{S}-\mathrm{SO}_{4} \\
\mathrm{mg} \mathrm{dm}^{-3}\end{array}$} & \multicolumn{2}{|c|}{ K C } & $\mathrm{Sa}$ & \multicolumn{2}{|c|}{$\frac{\mathbf{A l}^{\mathbf{l}^{+3}} \mathbf{H}+\mathbf{A} \mathbf{I}}{\mathrm{mmol}_{\mathrm{c}} \mathrm{dm}^{-3}}$} & SB & CTC & \multicolumn{2}{|c|}{$\mathbf{V}_{\%}^{\mathbf{M}}$} \\
\hline \\
\hline-5 & 3,98 & 4,85 & 34 & 11 & 10 & 2,6 & 1 & 2 & 4 & 40 & 5,6 & 45,6 & 12,3 & 41,7 \\
\hline $5-15$ & 3,76 & 4,55 & 30 & 4 & 3 & 2,6 & 1 & 2 & 8 & & 5,6 & 43,6 & 12,8 & 58,8 \\
\hline $15-25$ & 3,69 & 4,38 & 25 & 2 & 3 & 2,3 & 1 & 4 & 73 & 313 & 7,3 & 320,3 & 2,3 & 90,9 \\
\hline $25-40$ & 3,80 & 4,96 & 21 & 2 & 2 & 2,0 & 1 & 5 & 88 & $3 h$ & 8,0 & 363,0 & 2,2 & 91,6 \\
\hline $40-60$ & 4,00 & 5,20 & 19 & 2 & 2 & 1,6 & 1 & 13 & 37 & 161 & 15,6 & 176,6 & 8,8 & 70,3 \\
\hline $60-80$ & 4,94 & 5,76 & 20 & 2 & 1 & 1,1 & 1 & 27 & 1 & 19 & 29,1 & 48,1 & 60,5 & 0,0 \\
\hline \multicolumn{15}{|c|}{ Solo 2} \\
\hline & 01 & 71 & 43 & 18 & 12 & 2,1 & 4 & 24 & 19 & & 30,1 & 170,1 & 17,7 & 38,7 \\
\hline $5-10$ & 4,13 & 4,95 & 35 & 2 & 10 & 2,1 & 4 & 32 & 28 & 143 & 38,1 & 181,1 & 21,0 & 42,3 \\
\hline $10-20$ & 4,53 & 5,13 & 26 & 2 & 53 & 1,8 & 6 & 65 & 9 & 79 & 72,8 & 151,8 & 48,0 & 11,0 \\
\hline $20-35$ & 5,12 & 5,60 & 25 & 2 & 70 & 1,1 & 10 & 77 & 0 & 37 & 88,1 & 125,1 & 70,4 & 0,0 \\
\hline & 6,31 & 6,61 & 23 & 1 & & 1,1 & 11 & 75 & 0 & 7 & 87,1 & 105,1 & 83,0 & 0,0 \\
\hline $50-80$ & 6,96 & 7,2 & 21 & 1 & 73 & 1,2 & 12 & 74 & 0 & 12 & 87,2 & 99,2 & 88,0 & 0,0 \\
\hline
\end{tabular}

Tabela 12- Análise de micronutrientes, sódio e condutividade

\begin{tabular}{|c|c|c|c|c|c|c|c|}
\hline \multirow{2}{*}{ Solos } & B & $\mathrm{Cu}$ & $\mathbf{F e}$ & Mn & $\overline{Z n}$ & \multirow{2}{*}{$\begin{array}{c}\mathrm{Na} \\
\mathrm{mmol}_{\mathrm{c}} \mathrm{dm}^{-3}\end{array}$} & \multirow{2}{*}{$\begin{array}{c}\text { Condutividade } \\
\mathrm{dS} \mathrm{m}^{-1}\end{array}$} \\
\hline & & & $\mathrm{g} \mathrm{dm}$ & & & & \\
\hline \multicolumn{8}{|c|}{ Solo 1} \\
\hline $0-5$ & 0,16 & 0,4 & 89 & 13,2 & 1,5 & 1,0 & 0,35 \\
\hline $5-15$ & 0,15 & 0,5 & 104 & 8,6 & 0,7 & 1,1 & 0,14 \\
\hline $15-25$ & 0,12 & 0,4 & 35 & 9,0 & 0,3 & 5,7 & 0,04 \\
\hline $25-40$ & 0,18 & 0,5 & 7 & 7,0 & 0,1 & 9,7 & 0,03 \\
\hline $40-60$ & 0,20 & 0,4 & 18 & 7,6 & 0,5 & 13,5 & 0,03 \\
\hline $60-80$ & 0,20 & 0,2 & 21 & 8,0 & 0,3 & 20,0 & 0,08 \\
\hline \multicolumn{8}{|c|}{ Solo 2} \\
\hline $0-5$ & 0,50 & 2,3 & 239 & 113,0 & 1,7 & 20,0 & 0,53 \\
\hline $5-10$ & 0,57 & 2,0 & 84 & 98,2 & 0,7 & 28,5 & 0,43 \\
\hline $10-20$ & 0,65 & 1,3 & 47 & 66,2 & 0,4 & 46,0 & 0,93 \\
\hline $20-35$ & 0,99 & 1,1 & 28 & 33,0 & 0,4 & 49,0 & 1,21 \\
\hline $35-50$ & 1,79 & 1,4 & 23 & 24,8 & 0,4 & 60,0 & 2,30 \\
\hline $50-80$ & 1,80 & 1,1 & 22 & 17,8 & 0,4 & 65,0 & 2,60 \\
\hline
\end{tabular}

Segundo Camargo et. al. (1987) o solo1 é classificado como: Petroplintossolo álico Ta, A moderado, textura arenosa/argilosa e o solo2, como: Plintossolo sódico Tb, A moderado, textura argilosa. E conforme a nova nomenclatura da EMBRAPA (1999), o solo1 e do tipo: Plintossolo pétrico litoplíntico e o solo2: Plintossolo háplico eutrófico. 


\subsection{PrÉ-ENSAI dE INCUBAÇÃa}

No momento da segunda homogeneização dos solos, realizada em Piracicaba, se obteve uma amostra composta de cada solo oriunda de mais de 120 pontos distintos para uso neste ensaio de incubação. De posse dos resultados das análises do solo (Tabela 07) e do corretivo (Tabela 13), no dia 14/02/99 os solos foram incubados, para a elaboração das curvas de poder tampão.

Tabela 13- Análise do corretivo utilizado no experimento

\begin{tabular}{lcc}
\hline Descrição & Análise & $\%$ \\
\hline Óxido de cálcio & $\mathrm{CaO}$ & 34,16 \\
\hline Óxido de magnésio & $\mathrm{MgO}$ & 17,74 \\
\hline Soma de óxidos & & 51,90 \\
\hline Carbonato de cálcio & $\mathrm{CaCO}_{3}$ & 61,15 \\
\hline Carbonato de magnésio & $\mathrm{MgCO}_{3}$ & 44,00 \\
\hline Soma de carbonatos & & 105,15 \\
\hline Sílica e insolúveis & & 3,31 \\
\hline PN & & $\mathbf{1 0 2 , 0 0}$ \\
\hline & & $\%$ \\
Granulometria & Tyler Mesh & $\mathbf{1 0}$ \\
& 100,00 \\
\hline PRNT & 20 & 99,99 \\
\hline
\end{tabular}

O ensaio de incubação dos solos foi realizado em copos de $500 \mathrm{ml}$, contendo 500 $\mathrm{g}$ de solo. Foram utilizadas 6 doses de calcário para cada solo ( 6 tratamentos), com 3 repetições por tratamento perfazendo 18 observações por solo. Os tratamentos para o solo 01 foram a testemunha e mais 5 quantidades de calcário suficientes para se atingir $34,49,64,79$ e 94 de saturação de bases final. Já para o solo 02 os tratamentos foram testemunha e mais 5 quantidades de calcário suficientes para se atingir 37, 51, 65, $79 \mathrm{e}$ 93 de saturação de bases final. O calcário utilizado na incubação foi todo passado na peneira de 50 mesh, tornando-se portanto a ter PRNT de 102\%. 
Após agitação do solo com o calcário cada parcela foi irrigada até a capacidade de campo de cada solo. Estes foram mantidos na mesma casa de vegetação onde se realizou o experimento com as forrageiras. A hidratação das parcelas era realizada diariamente para se atingir a capacidade de campo, sendo a quantidade de água empregada, calculada através de pesagens. $O$ período de incubação se estendeu por 40 dias, sendo que a cada 5 dias foram coletadas amostras para a determinação de $\mathrm{pH}$ em $\mathrm{H}_{2} \mathrm{O}$, em $\mathrm{CaCl}_{2}$ e em solução SMP. As amostras coletadas seguiram ao padrão de rotina de análise de solo, indo à estufa para secagem e posteriormente seguindo as normas de cada determinação. Optou-se por finalizar a incubação no $40^{\circ}$ dia, já que os parâmetros de $\mathrm{pH}$ permaneceram praticamente inalterados após o $20^{\circ}$ dia de incubação. Neste período foram realizadas aproximadamente 972 medições de $\mathrm{pH}$. E finalmente no $40^{\circ}$ dia de incubação as amostras dos solos foram encaminhadas para a análise laboratoriais completas de macro e micronutrientes.

\subsection{DELINEAMENTI EXPERIMENTAL}

O presente experimento teve como objetivo central determinar a necessidade de calagem para cada espécie forrageira em cada um dos solos avaliados, não tendo portanto a intenção de confrontar resultados entre os capins ou entre os solos. Sendo assim a análise estatística foi realizada independentemente, avaliando cada espécie cultivada em cada um dos solos. O delineamento utilizado foi o inteiramente casualizado, tendo o seguinte modelo:

$$
Y_{i j}=\mu+C_{i}+e_{i j}
$$

Onde: $i=1,2,3,4$ e $5 ; \quad j=1,2,3$

$\mathbf{y}_{\mathbf{i j}}=$ é o valor observado;

$\mu=$ media geral, é uma constante;

$\mathbf{C}_{\mathbf{i}}=$ efeito da i-ésima dose de calcário;

$e_{i j}=$ erro aleatório, tal que $e_{i} \cap N\left(0, \sigma^{2}\right)$ e independentes. 
Cada espécie foi submetida a cinco tratamentos sob cada um dos solos, com três repetições, totalizando desta forma 120 unidades amostrais. Sendo então agrupadas em 8 conjuntos de 15 unidades amostrais (1 espécie, 1 solo, 5 Tratamentos e 3 repetições), conforme a seguinte análise de variância (Tabela 14). Os dados foram analisados com auxílio do pacote estatístico SAS 6.11 do SAS Institute Inc (1991).

Tabela 14- Quadro de Análise de Variância

\begin{tabular}{llc}
\hline C.V. & G.L. \\
\hline Tratamento & 4 \\
\hline Resíduo &.. & 10 \\
\hline Total & & 14 \\
\hline
\end{tabular}

O pré-ensaio de incubação teve um quadro de análise de variância próprio com 5 , 12 e 17 graus de liberdade, respectivamente para tratamento, resíduo e total.

\subsection{TRATAMENTIS}

Os tratamentos foram constituídos de uma testemunha (solo sem calagem) e mais 4 doses crescentes de calcário (Tabela 15).

Tabela 15- Tratamentos

\begin{tabular}{|c|c|c|c|c|}
\hline \multirow{2}{*}{ Doses } & \multicolumn{2}{|c|}{ Solo 1} & \multicolumn{2}{|c|}{ Solo 2} \\
\hline & $\mathbf{V} \%$ & $\mathrm{mg} \mathrm{kg}^{-1}$ & V\% & $\mathrm{mg} \mathrm{kg}^{-1}$ \\
\hline 0 & $T(10)$ & - & $T(15)$ & - \\
\hline $1^{0}$ & V30 & 400,91 & V35 & 1122,87 \\
\hline $2^{\circ}$ & V50 & 973,05 & V55 & 2507,92 \\
\hline $3^{\circ}$ & V70 & 1545,18 & V75 & 3892,96 \\
\hline $4^{0}$ & V90 & 2117,32 & V95 & 5277,99 \\
\hline Equação* & \multicolumn{2}{|c|}{$\begin{array}{c}\mathrm{QC}=\left(\mathrm{V}_{\mathrm{F}}-15,985673\right) \\
0,034957\end{array}$} & \multicolumn{2}{|c|}{$\begin{array}{c}Q C=\left(V_{F}-18,785714\right) \\
0,014440\end{array}$} \\
\hline
\end{tabular}

*- Equações determinadas pelo pré-ensaio de incubação, onde QC é a quantidade de calcário em ( $\mathrm{mg} \mathrm{kg}^{-1}$ ) e $V_{F}$ é a saturação por bases final desejada. 
A elevação da saturação por bases foi realizada com doses crescentes do mesmo calcário dolomítico utilizado no pré-ensaio de incubação, cuja análise encontra-se na Tabela 13. O critério de calagem foi baseado em se estabelecer índices crescentes e eqüidistantes de saturações por bases, utilizando-se para tal das equações geradas no préensaio de incubação dos solos.

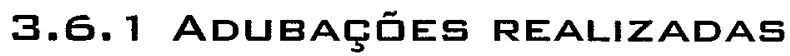

As adubações realizadas foram preconizadas para que não existisse deficiência de qualquer outro elemento que não Ca e $\mathrm{Mg}$, que são obviamente os alvos do estudo. A Tabela 16 mostra as doses de cada nutriente, assim como suas respectivas fontes, utilizadas nas adubações de plantio e nos demais cortes.

Tabela 16- Adubações realizadas. Quantidades do nutriente $\left(\mathrm{mg} \mathrm{kg}^{-1}\right)$

\begin{tabular}{|c|c|c|c|c|c|c|c|}
\hline \multirow{2}{*}{ Nutriente } & \multirow{2}{*}{ Fontes utilizadas } & \multicolumn{2}{|c|}{ Plantio } & \multicolumn{2}{|c|}{ Após $1^{\circ}$ corte } & \multicolumn{2}{|c|}{ Após $2^{\circ}$ Corte } \\
\hline & & Solo 1 & Solo 2 & Solo 1 & Solo 2 & Solo 1 & Solo 2 \\
\hline $\mathbf{P}$ & $\mathrm{NH}_{4} \mathrm{H}_{2} \mathrm{PO}_{4}$ & 70 & 80 & - & - & 20 & 20 \\
\hline $\mathbf{K}$ & $\mathrm{KH}_{2} \mathrm{PO}_{4}, \mathrm{KCl}$ & 80 & 80 & 50 & 50 & 200 & 200 \\
\hline $\mathbf{S}$ & $\left(\mathrm{NH}_{4}\right)_{2} \mathrm{SO}_{4}$ & 25 & - & 10 & 10 & 20 & 20 \\
\hline $\mathbf{N}$ & $\begin{array}{c}\mathrm{NH}_{4} \mathrm{H}_{2} \mathrm{PO}_{4}\left(\mathrm{NH}_{4}\right)_{2} \mathrm{SO}_{4} \\
\left(\mathrm{NH}_{4}\right) \mathrm{NO}_{3}\end{array}$ & 50 & 50 & 100 & 100 & 275 & 275 \\
\hline Mn & $\mathrm{MnSO}_{4} \cdot \mathrm{H}_{2} \mathrm{O}$ & 4 & - & - & - & 1 & 1 \\
\hline Zn & $\mathrm{ZnSO}_{4}$ & 3 & 3 & - & - & 1 & 1 \\
\hline $\mathrm{Cu}$ & $\mathrm{CuSO}_{4} .5 \mathrm{H}_{2} \mathrm{O}$ & 2 & 1 & - & - & 0,5 & 0,5 \\
\hline B & $\mathrm{H}_{3} \mathrm{BO}_{3}$ & 1,5 & 1 & - & - & 0,4 & 0,4 \\
\hline Mo & $\mathrm{Na}_{2} \mathrm{MoO}_{4} \cdot 2 \mathrm{H}_{2} \mathrm{O}$ & 0,1 & 0,1 & - & - & 0,05 & 0,05 \\
\hline
\end{tabular}

Foram utilizados neste experimento reagentes analíticos como fonte dos nutrientes. As adubações foram aplicadas na forma de soluções aquosas, utilizando-se volumes entre 500 e $1000 \mathrm{ml}$ por vaso por aplicação. As aplicações de nitrogênio formam parceladas nos primeiros 15 dias após plantio e a cada corte. 
3.7 PARÂMETRLS ANALISADIS E METIDLLOGIAS EMPREGADAS

\subsubsection{DETERMinAçŨEs No MATERIAL VEgEtal}

No primeiro corte foram analisados os seguintes parâmetros: $\mathrm{n}^{\circ}$ de perfilhos por geração (surgimento semanal); $\mathrm{n}^{\circ}$ total de perfilhos no momento do corte (NP); peso natural de perfilhos por geração (PP); produção de matéria natural total (MNT); produção de matéria seca total (MST); composição botânica [matéria seca de lâminas foliares expandidas (MSFE), matéria seca de lâminas foliares em expansão (MSFEE), matéria seca de bainha+hastes (MSH) (Figuras 9, 10, 11 e 12)]. Além de outros parâmetros indiretos como: teores de matéria seca (TMS), taxas de acumulo diário (TA) e relações folha:haste (RFH).
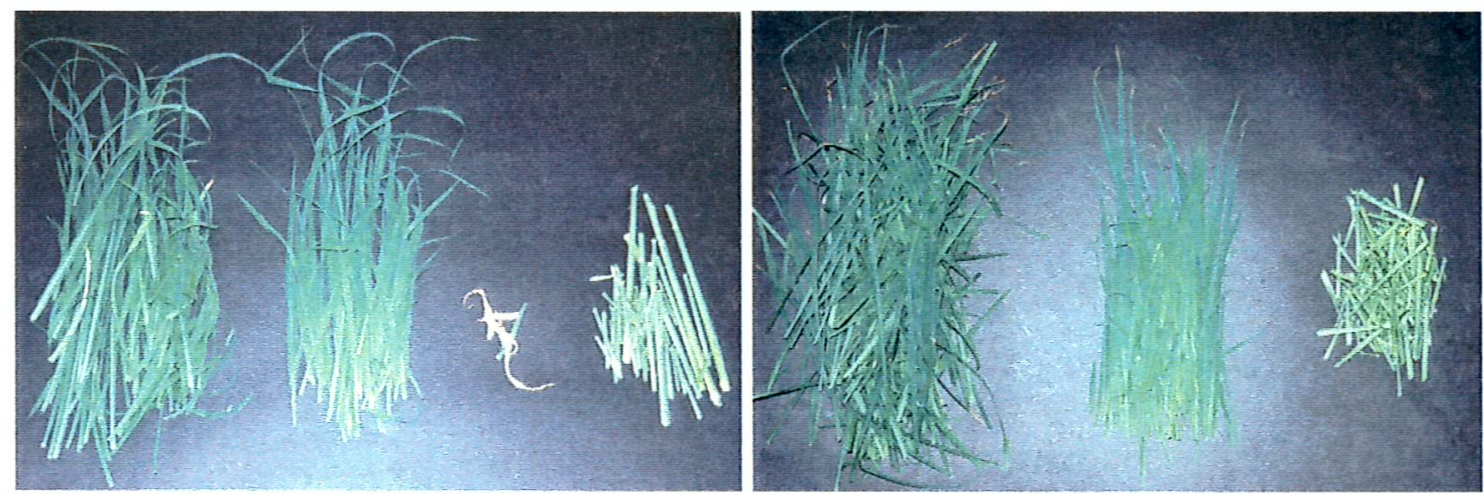

Figura 9 e 10- Composição botânica das espécies E. polystachya e E. pyramidalis.
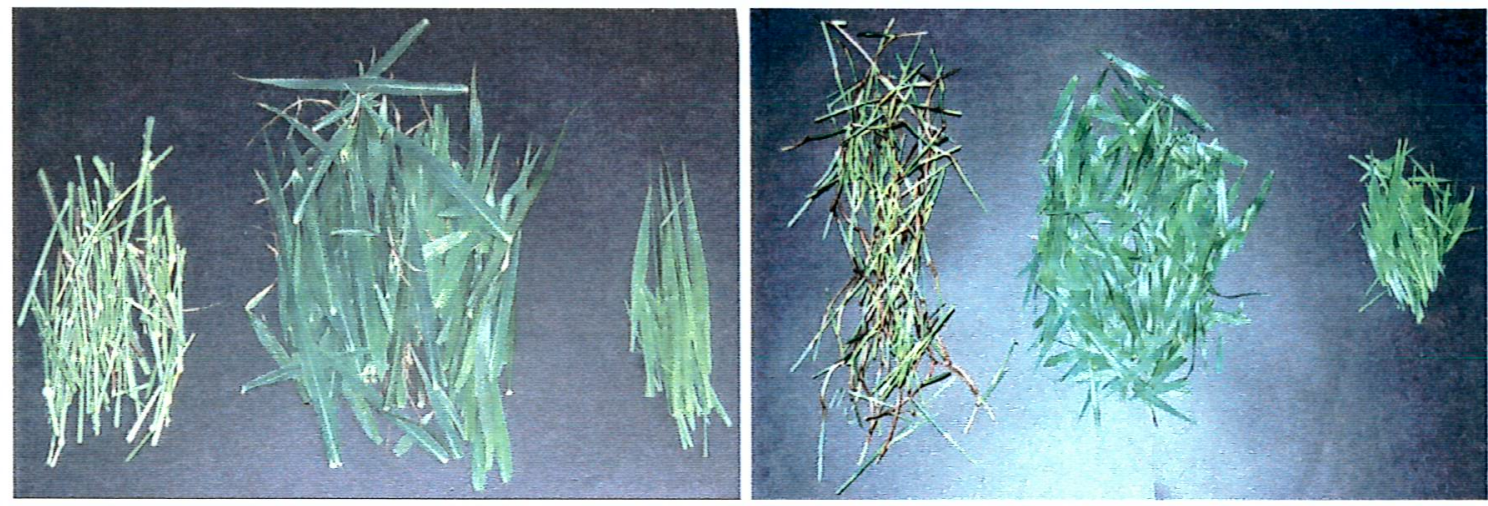

Figura 11 e 12- Composição botânica das espécies B. mutica e B. humidicola. 
No segundo e terceiro corte foram analisados: NP, MNT, MST, MSFE, MSFEE, MSH, matéria natural de lâminas foliares expandidas (MNFE), matéria natural de lâminas foliares em expansão (MNFEE), màtéria natural de bainhathastes (MNH), área foliar de folhas expandidas (AFFE), área foliar de folhas em expansão (AFFEE). Além de outros parâmetros indiretos como: TMS, TA e RFH. E ao final do terceiro e último corte produção de raízes (MSR).

A matéria seca dos tecidos vegetais da parte aérea e das raízes foi determinada em estufa com circulação de ar forçado com temperaturas entre 60 e $65^{\circ} \mathrm{C}$ por $72 \mathrm{~h}$ (présecagem). Nos tecidos sujeitos a determinações laboratoriais, seguiu-se com uma subamostra para secagem definitiva a $105^{\circ} \mathrm{C}$.

A área foliar foi determinada com auxílio do equipamente: Area Meter LI-3100, produzido pela Li-cor Inc, USA.

As folhas após terem tido suas matérias sècas determinadas foram agrupadas (folhas expandidas + folhas em expansão) e moídas em moinho tịpo "Willey", passando em peneira de $1 \mathrm{~mm}$, pára então serem, encaminhadas para doís laboratórios distintos.

No Laboratório de Solos e Nutrição de Plantas da ESLAQ foram determinados os seguintes minerais: $\mathrm{Ca}, \mathrm{Mg}, \mathrm{K}, \mathrm{P}, \mathrm{S}, \mathrm{Zn}, \dot{\mathrm{Cu}}, \mathrm{Fe}, \mathrm{Mn}, \mathrm{B}$ e $\mathrm{Na}$. Estes foram determinados a partir de um extrato obtido por digestão nitro-perclórica (exceto o boro). O fósforo foi determinado colorimetricamente; o potássio e o sódio por fotometria de chama; $\mathrm{Ca}, \mathrm{Mg}, \mathrm{S}, \mathrm{Zn}, \mathrm{Cu}, \mathrm{Fe}$ e $\mathrm{Mn}$ por espectrofotometria de absorção atômica (Sarruge \& Haag, 1974). E finalmente o boro, foi extração a seco e determinado pelo método colorimétrico-azometina-H (Bataglia et al., 1983).

No laboratório de Bromatologia do Departamento de Produção Animal da ESALQ foram determinados: matéria seca definitiva, matéria mineral e proteína bruta (PB) de acordo com o A.O.A.C (1990); fibra em detergente neutro (FDN), fibra em detergente ácido (FDA) e Lignina de acordo com Van Soest et al. (1991), adaptado para o aparelho $\mathrm{ANKOM}^{200}$ da Ankom Technology Corporation USA; A Digetibilidade "in vitro" da matéria orgânica seguiu metodologia de Tilley \& Terry (1963), modificado por Tinnimit (1974), adaptado para o aparelho DAISY Incubator da Ankom Technology 
Corporation, USA. Sendo que todos estes parâmetros determinados no Laboratório de Bromatologia foram analisados com auxílio da tecnologia NIRS (Near Infrared Reflectance Spectroscopy) utilizando-se do aparelho fabricado pela FOSS NIRSystem USA, e as equações geradas com o software WinISI II (ISI Windows Near-Infrared Software, versão $1.02 \mathrm{a}$ ).

\subsubsection{DETERMINAÇÕES ND SDLD}

As amostras de solo foram analisadas no Departamento de solos e nutrição de plantas para as seguintes determinações: $\mathrm{pH}$ em $\mathrm{H}_{2} \mathrm{O}(1: 2,5) ; \mathrm{pH}$ em $\mathrm{CaCl}_{2} \quad 0,01 \mathrm{M}$ $(1: 2,5)$; matéria orgânica; macronutrientes $\left(\mathrm{P}, \mathrm{K}, \mathrm{Ca}, \mathrm{Mg}, \mathrm{SO}_{4}{ }^{2-} \mathrm{e} \mathrm{Na}\right)$; micronutrientes $(\mathrm{Zn}, \mathrm{Cu}, \mathrm{Fe}, \mathrm{Mn}$ e $\mathrm{B}) ; \mathrm{H}+\mathrm{Al}$ e $\mathrm{Al}^{3+}$. $\mathrm{O} \mathrm{Na}$ e o $\mathrm{SO}_{4}{ }^{2-}$ só foram determinados nas amostras do pré-plantio.

A matéria orgânica foi extraída em via úmida e determinada colorimetricamente; a acidez potencial $(\mathrm{H}+\mathrm{Al})$ foi determinada através da solução tampão $\mathrm{SMP}$; o $\mathrm{P}, \mathrm{Ca}, \mathrm{Mg}$ e $\mathrm{K}$ foram extraídos pelo método da resina trocadora de íons, o sódio por solução extratora de Mehlich, sendo o fósforo determinado colorimetricamente pelo método do Molibdato Azul, o potássio e o sódio por fotometria de chama e finalmente o Ca e $\mathrm{Mg}$ por espectrofotometria de absorção atômica (Raij et al., 1987). $\mathrm{O} \mathrm{Al}^{3+}$ foi extraído com solução de $\mathrm{KCl} 1 \mathrm{~N}$ e determinado por titulação com $\mathrm{NaOH}$. Os micronutrientes $\mathrm{Zn}, \mathrm{Cu}$, Fe e Mn foram extraídos com solução de $\mathrm{HCl} 0,1 \mathrm{M}$ e determinados por espectrofotometria de absorção atômica (Bataglia \& Raij, 1989). O $\mathrm{SO}_{4}{ }^{2-}$ foi extraído pelo acetato de amônio $0,5 \mathrm{~N}$ em ácido acético $0,25 \mathrm{~N}$ e determinado medindo-se a turbidez formada pela precipitação com $\mathrm{BaCl}_{2}$ em espectrofotometria de absorção atômica. E finalmente o boro foi extraído com solução de $\mathrm{CaCl}_{2} \quad 0,01 \mathrm{M}$ e determinado pelo método colorimétrico azometina-H (Bataglia \& Raij, 1989). 


\subsection{PREPARAÇÃ E DESENVLLVIMENTI Da EXPERIMENTU}

\subsection{1 口BTENÇÃ́ DAS MUDAS}

Sabendo que das 4 espécies forrageiras avaliadas neste estudo, somente uma produz sementes viáveis, optou-se por plantar todas por meio vegetativo. Portanto para termos mudas viáveis e em quantidade suficiente para plantio nos vasos, foram cultivados canteiros para o fornecimento das mesmas.

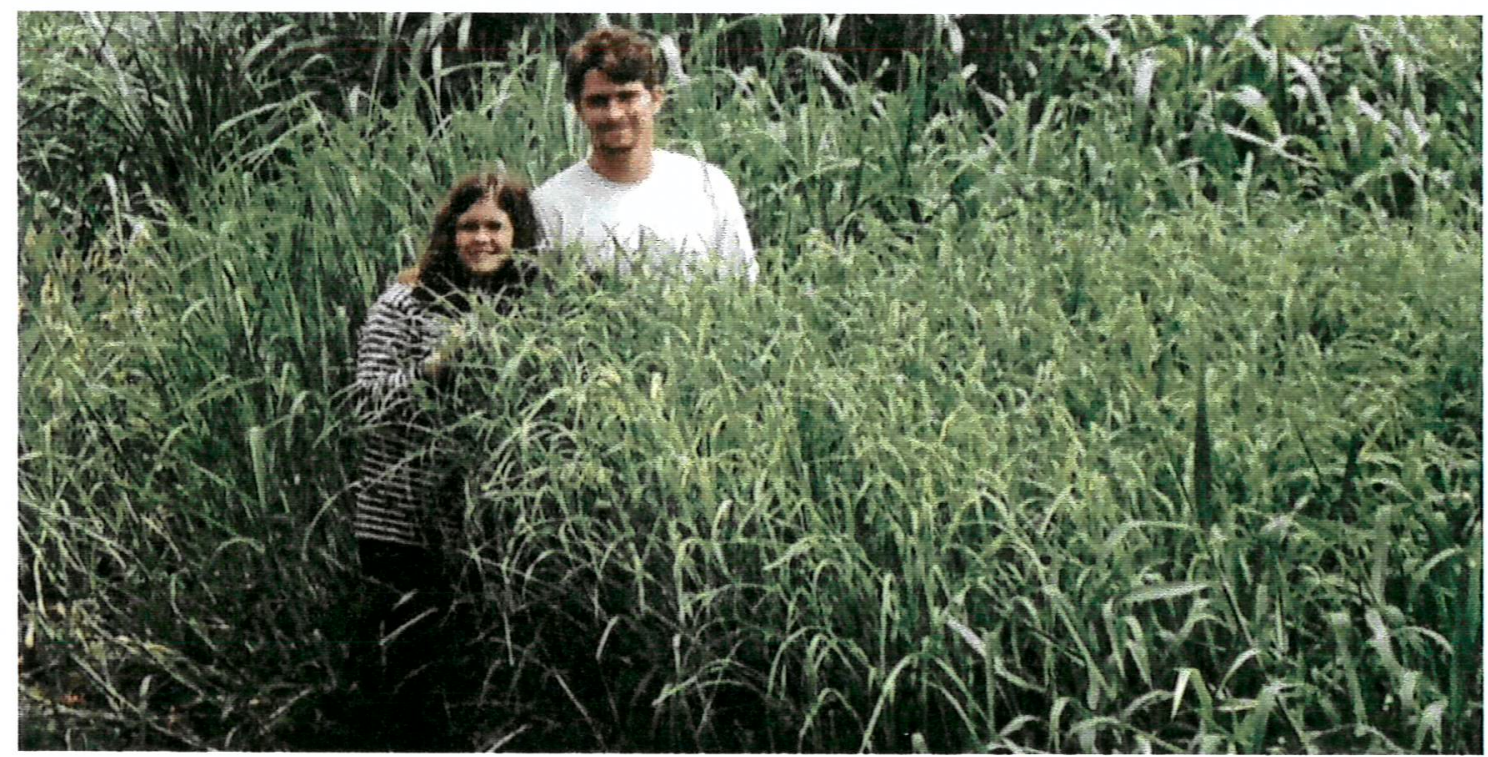

Figura 13- Canteiros utilizados para o fornecimanto das mudas.

Os canteiros foram implantados em uma área próxima ao Departamento de Produção Animal da ESALQ, tendo uma área plantada por espécie de $12 \mathrm{~m}^{2}$ (4m x 3m). As mudas das espécies Brachiaria mutica, Brachiaria humidicola e Echinochloa pyramidalis foram obtidas no Instituto de Zootecnia de Nova Odessa - SP, e as mudas de Echinochloa polystachya, foram enviadas por sedex do CPATU-EMBRAPA de BelémPA. De tal modo que em setembro de 1998 todos os canteiros (Figura 13) já estavam implantados. Os canteiros receberam, sempre que se julgou necessário, cuidados 
periódicos (cortes, adubações e irrigações) desde a implantação até o momento de fornecimento de mudas para o plantio definitivo em casa de vegetação.

\subsubsection{PREPARAÇÃa, plantia e conduçÃo}

Assim que desembarcados em Piracicaba, os solos foram encaminhados para casa de vegetação, onde foram desensacados e novamente homogeneizados. Neste momento se obteve uma amostra composta de cada solo, oriunda de mais de 120 subamostras, para uso no ensaio de incubação, bem como para a realização das análises laboratoriais necessárias.

Foram utilizados para o plantio vasos plásticos de coloração vermelho cerâmica claro, forrados com sacos plásticos transparentes. Os vasos foram preenchidos com $9 \mathrm{~kg}$ de solo e devidamente identificados com etiquetas.

De pose das equações que definiram as quantidades de calcário para cada solo e seus respectivos tratamentos, procedeu-se o período de incubação pré-plantio. A mistura do solo ao corretivo foi realizada com auxílio de sacos plásticos agitando-se vigorosamente por 3 minutos. Durante os dias 26 e 27/08/1999 os 120 vasos receberam o corretivo e no dia 29/08 foram irrigados com água destilada para atingir a capacidade de campo. O período de incubação se estendeu até o dia 02/10/1999, sendo realizadas neste período, a cada 3 dias pesagens dos vasos, com intuito de manter os solos irrigados próximo à capacidade de campo.

Os vasos foram arranjados inteiramente ao acaso, onde cada bancada possuía um único ensaio (delineamento estatístico independente); composto de uma espécie de forragem cultivada em um tipo de solo, recebendo os 5 tratamentos com suas 3 repetições, perfazendo portanto as 15 parcelas. No total foram utilizadas 8 bancadas para que se completasse todo o experimento, que conteve 120 vasos (Figuras 14 e 15). Duas vezes por semana os vasos tiveram suas posições alteradas na bancada, alterando-se uma vez a posição das colunas e outra vez as das linhas (Figura 16). Após o segundo corte devido ao crescimento vigoroso das plantas, subdividiu-se cada ensaio em duas bancadas, passando o experimento a ocupar portanto 16 bancadas no período final. 


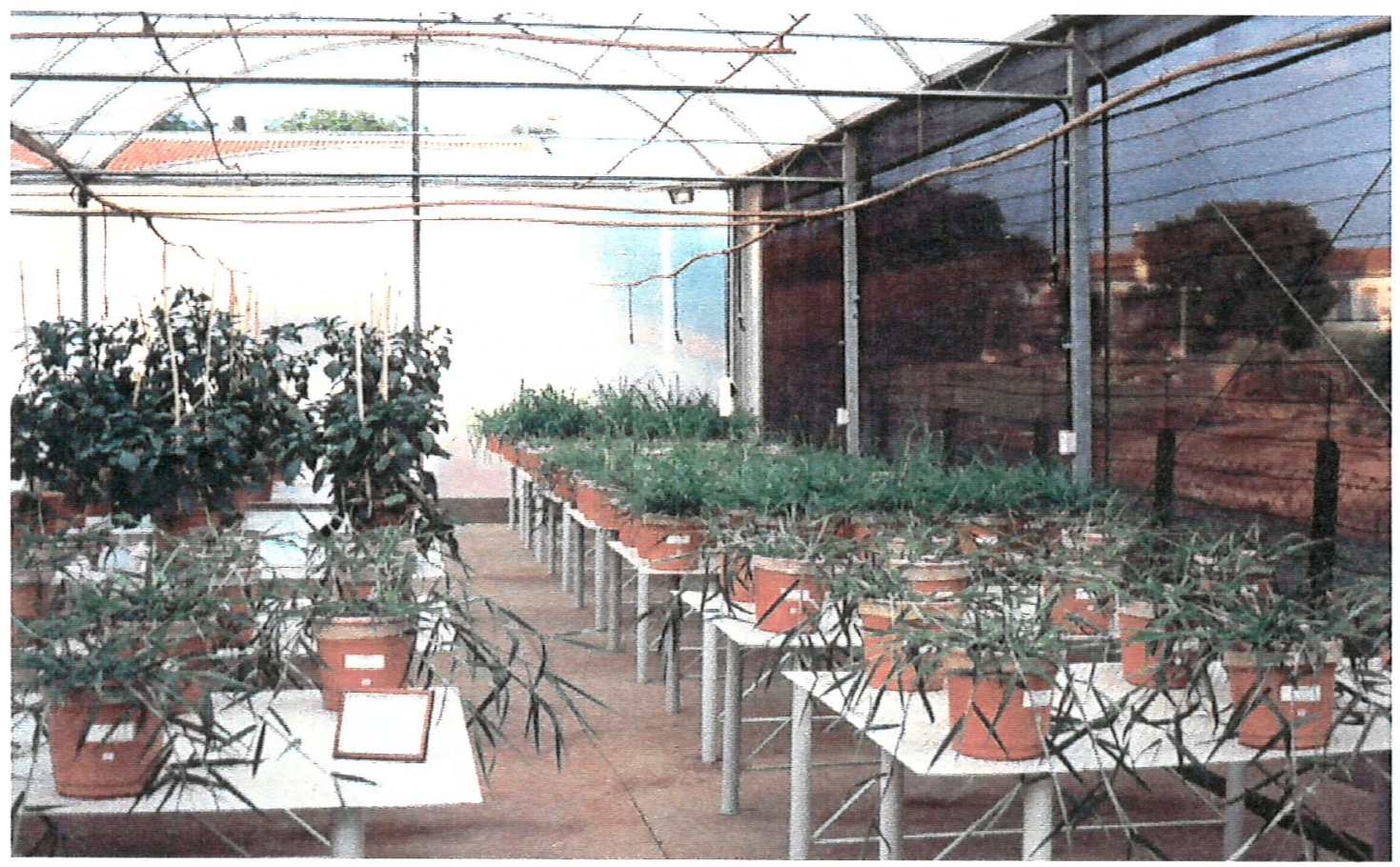

Figura 14- Visão geral da casa de vegetação.

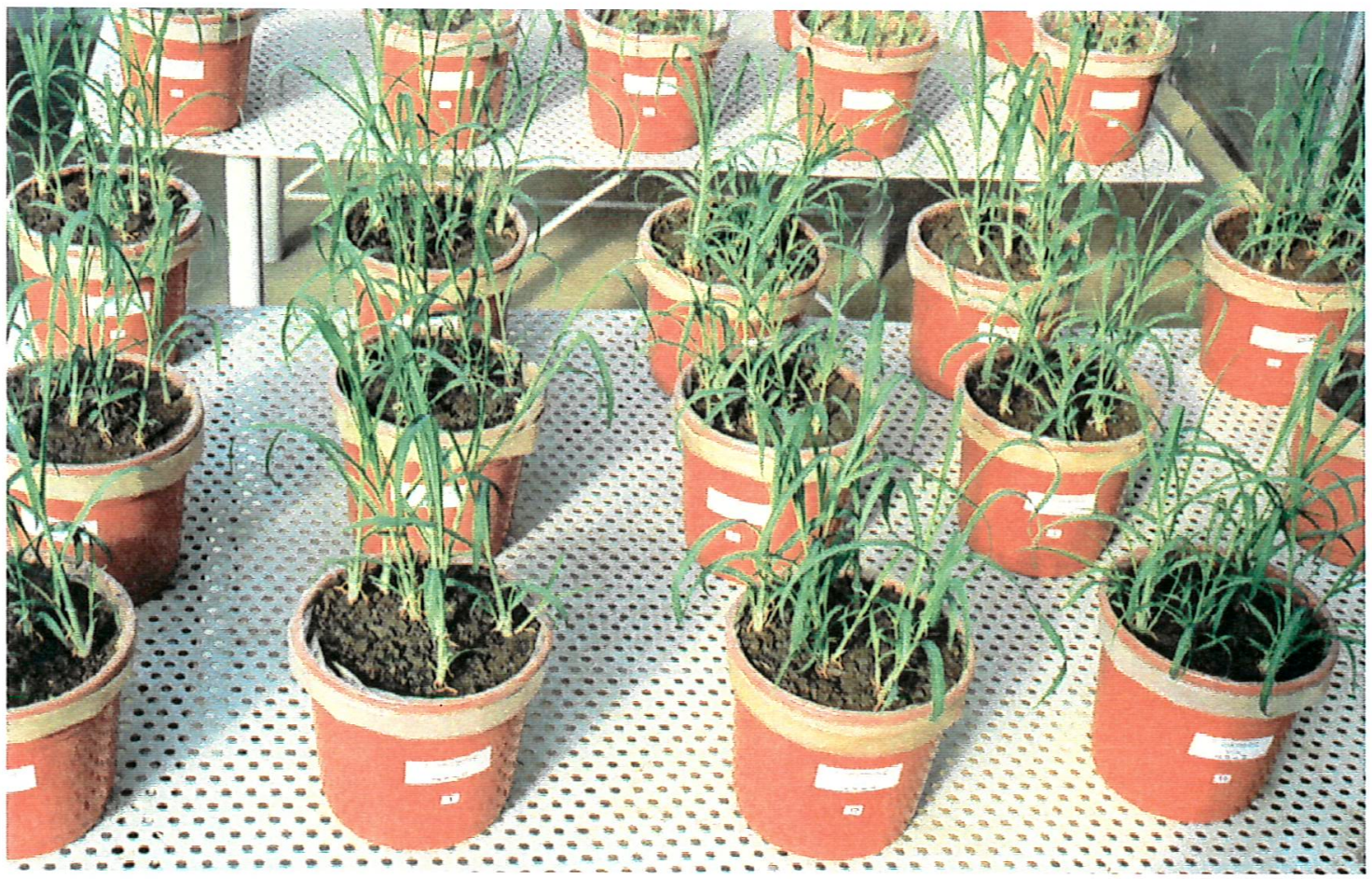

Figura 15- Visão da distribuição dos vasos na bancada. 


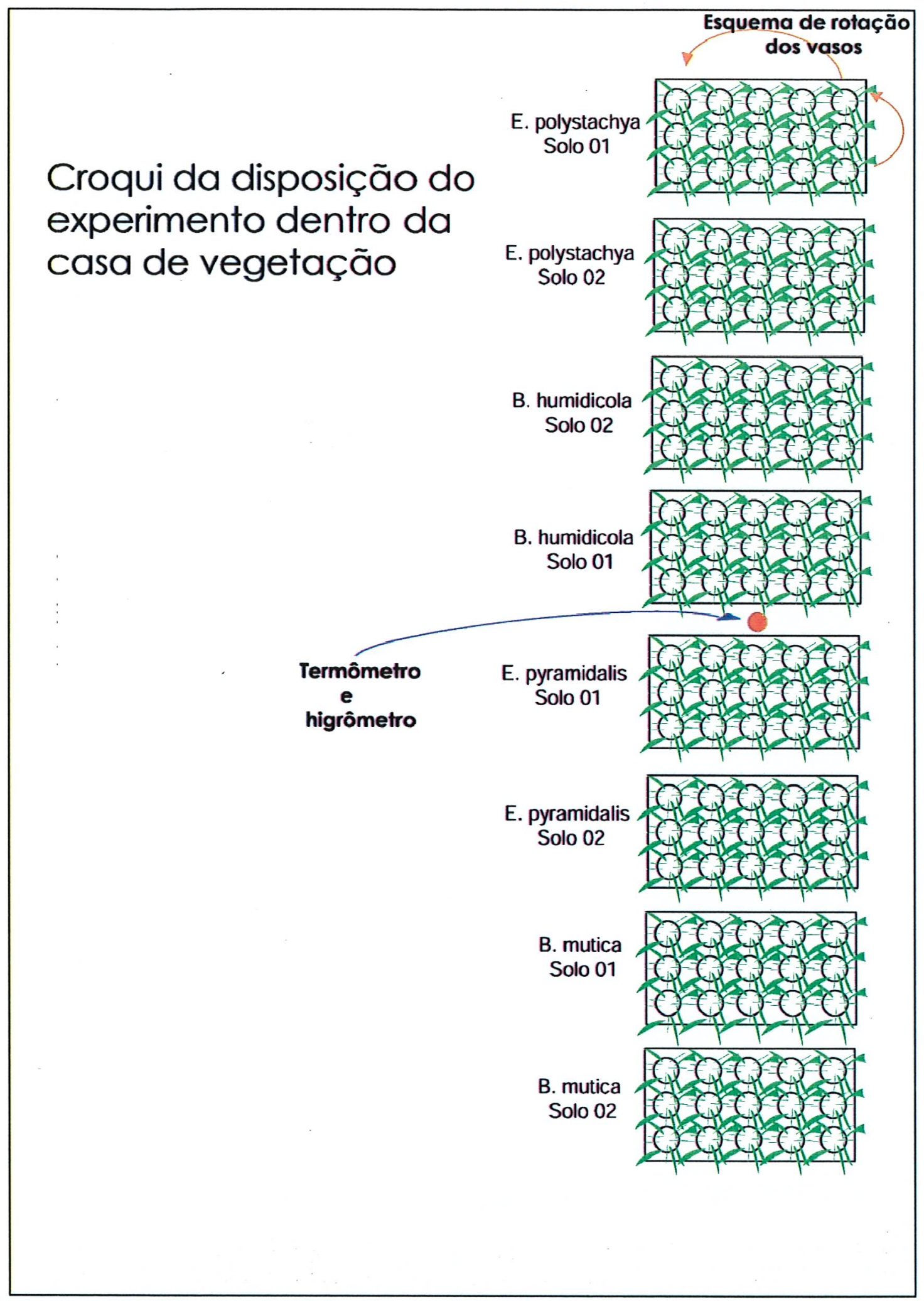

Figura 16- Disposição dos vasos na casa de vegetação; esquema de troca de vasos e posicionamento do termômetro e higrômetro. 
Após o período de incubação definitiva dos vasos, iniciou-se o plantio das mudas das forrageiras entre os dias 2 e 5/10/1999. As mudas foram retiradas dos canteiros, sendo imediatamente transplantadas para os vasos.

As mudas de E. polystachya e B. mutica, constituíam-se de uma fração de haste madura de aproximadamente 5-7 cm contendo apenas uma única gema (nó); já as mudas de E. pyramidalis e $B$. humidicula eram constituídas de perfilhos completos, reduzindose parte de suas raízes e folhas. $\mathrm{O}$ número de mudas plantadas por vasos variou entre 10 e 15 conforme a espécie, sendo que o número de mudas mantidas após desbaste foi de 8 , 8,7 e 6 respectivamente para a $E$. polystachya, B. humidicola, B. mutica e $E$. pyramidalis tendo o desbaste ocorido por volta de 10 dias após o plantio, e no mesmo momento um replantio nas parcelas onde não se atingiu um número mínimo de mudas viáveis, que ocorreu somente para as espécies E. pyramidalis e B. humidicula cultivadas no solo 1.

Os vasos foram irrigados 3 vezes ao dia com água destilada, utilizando-se como critérios observação visual e tato para se verificar a umidade dos mesmos e a necessidade de irrigação. Durante toda a fase do crescimento das forrageiras foram monitoradas a temperatura e umidade relativa da casa de vegetação. Sendo estas averiguações, realizadas 3 vezes ao dia $(6: 00,12: 00$ e 18:00 h), sendo anotado em cada um destes horários a temperaturas e umidade existente no momento, bem como as temperaturas máxima e mínima correspondente a cada período (Apêndice Tabela 1). Conforme a observação diária destes parâmetros ambientais tentava-se dentro do possível, através de abertura e fechamento das cortinas laterais e do lanternin da casa de vegetação manter-se uma temperatura interna mínima de $15^{\circ} \mathrm{C}$ e máxima de $35^{\circ} \mathrm{C} . \mathrm{E}$ ainda sempre que a umidade relativa do ar caia abaixo de $35 \%$ procedia-se o umedecimento do piso da casa de vegetação com auxílio de mangueiras na tentativa de se aumentar a umidade relativa do ambiente. 


\subsubsection{CLLETA DIS DADQS EXPERIMENTAIS}

Após o período de incubação do solo com o calcário e imediatamente após cada corte foram realizadas amostragens de solo, estas amostragens foram realizadas com auxílio de tubos de aço inox que possuíam diâmetro de $2 \mathrm{~cm}$, coletou-se a uma profundidade de $15 \mathrm{~cm}$ num total de 8 cilindros amostrais por vaso (Figura 17), seguindo então estas amostras imediatamente para secagem e posteriormente para as análises laboratoriais. As amostras do pré-plantio foram compostas, retirando-se um total de 40 , já as amostras retiradas após cada corte foram individuais, totalizando 360 amostras.
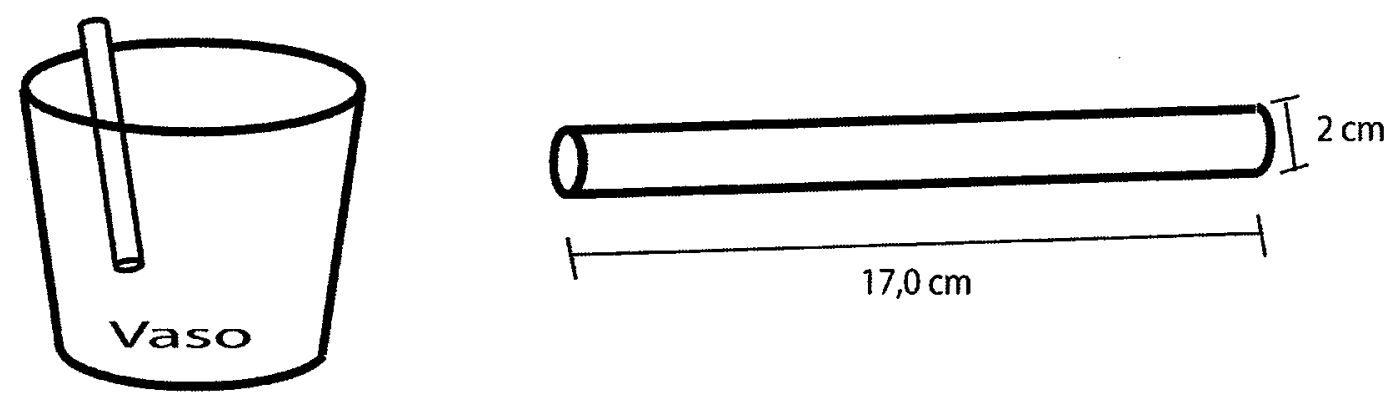

Figura 17- Procedimento de coleta de amostra dos solos e dimensões da sonda.

Entre o plantio e o primeiro corte, foram realizadas marcações semanais do surgimento de novos perfilhos para que fosse possivel a visualização da dinâmica de perfilhamento neste período. Os perfilhos eram marcados através do uso de anéis coloridos, tendo uma cor para cada geração. Após o segundo corte devido ao grande número de perfilhos (Por exemplo: a $B$. humidicola chegou a produzir até 500 perfilhos/vaso), inviabilizou-se a realização de medidas semanais e este parâmetro passou a ser avaliado somente no momento dos cortes, onde se contava o numero total de perfilhos existentes.

Os cortes foram realizados com auxílio de tesouras tentando se preservar ao máximo o meristema apical de cada espécie desta forma, as espécies do gênero Echinochloa e a B. mutica foram cortadas a $6 \mathrm{~cm}$ do solo no primeiro corte e a $8 \mathrm{~cm}$ no 
segundo e terceiro corte, enquanto a $B$. humidicola foi cortada a $4 \mathrm{~cm}$ no primeiro corte e a $6 \mathrm{~cm}$ no segundo e terceiro corte. Imediatamente após o corte dos perfilhos, foi feita a composição botânica dos mesmos, pesando-se em seguida cada componente.

As folhas seguiam para o integrador de área foliar e finalmente todos os componentes eram acondicionados em sacos de papel, indo em seguida à estufa para determinação de matéria seca. O período de crescimento de cada espécie, em cada corte, está ilustrado na Tabela 17.

Tabela 17- Período de crescimento em dias das quatro espécies forrageiras

\begin{tabular}{lcccccccc}
\hline \multirow{2}{*}{ Espécie } & \multicolumn{2}{c}{$\mathbf{1}^{\mathbf{0}}$ Corte } & \multicolumn{2}{c}{$\mathbf{2}^{\mathbf{0}}$ Corte } & \multicolumn{2}{c}{$\mathbf{3}^{\circ}$ Corte } & \multicolumn{2}{c}{ Total } \\
\cline { 2 - 10 } & Solo1 & Solo2 & Solo1 & Solo2 & Solo1 & Solo2 & Solo1 & Solo2 \\
\hline E. polystachya & 34 & 32 & 22 & 22 & 24 & 24 & 80 & 78 \\
\hline B. pyramidalis & 41 & 34 & 24 & 26 & 22 & 20 & 87 & 80 \\
\hline B. mutica & 36 & 34 & 24 & 24 & 22 & 22 & 82 & 80 \\
\hline B. humidicola & 39 & 32 & 26 & 26 & 26 & 26 & 91 & 84 \\
\hline Média & 37,5 & 33,0 & 24,0 & 24,5 & 23,5 & 23,0 & 85,0 & 80,5 \\
\hline
\end{tabular}

Ao final do terceiro corte, o material vegetal existente entre o solo e as respectivas alturas de corte de cada espécie foi cortado rente ao solo constituindo o que foi chamado de coroa (composto basicamente por hastes), seguindo para estufa para determinação de matéria seca que foi utilizada para compor o parâmetro produção total de matéria seca da parte aérea (Figuras 18 a 21).

Ainda ao final deste último corte por não haver tempo hábil para a separação das raízes do solo, os mesmos foram encaminhados para câmera fria mantida a temperaturas próximo a $0^{\circ} \mathrm{C}$, sendo paulatinamente descongelados para a separação das raízes, que foi realizada com auxílio de jatos de água pressurizados, ficando o bloco de solo apoiado em cima de peneiras com aberturas de $5 \mathrm{~mm}$.

Durante todo o experimento, várias etapas do ensaio foram registradas em meio fotográfico, verificando-se possíveis aparecimentos de sintomas de deficiência ou toxidez de minerais decorrentes dos distintos tratamentos. 

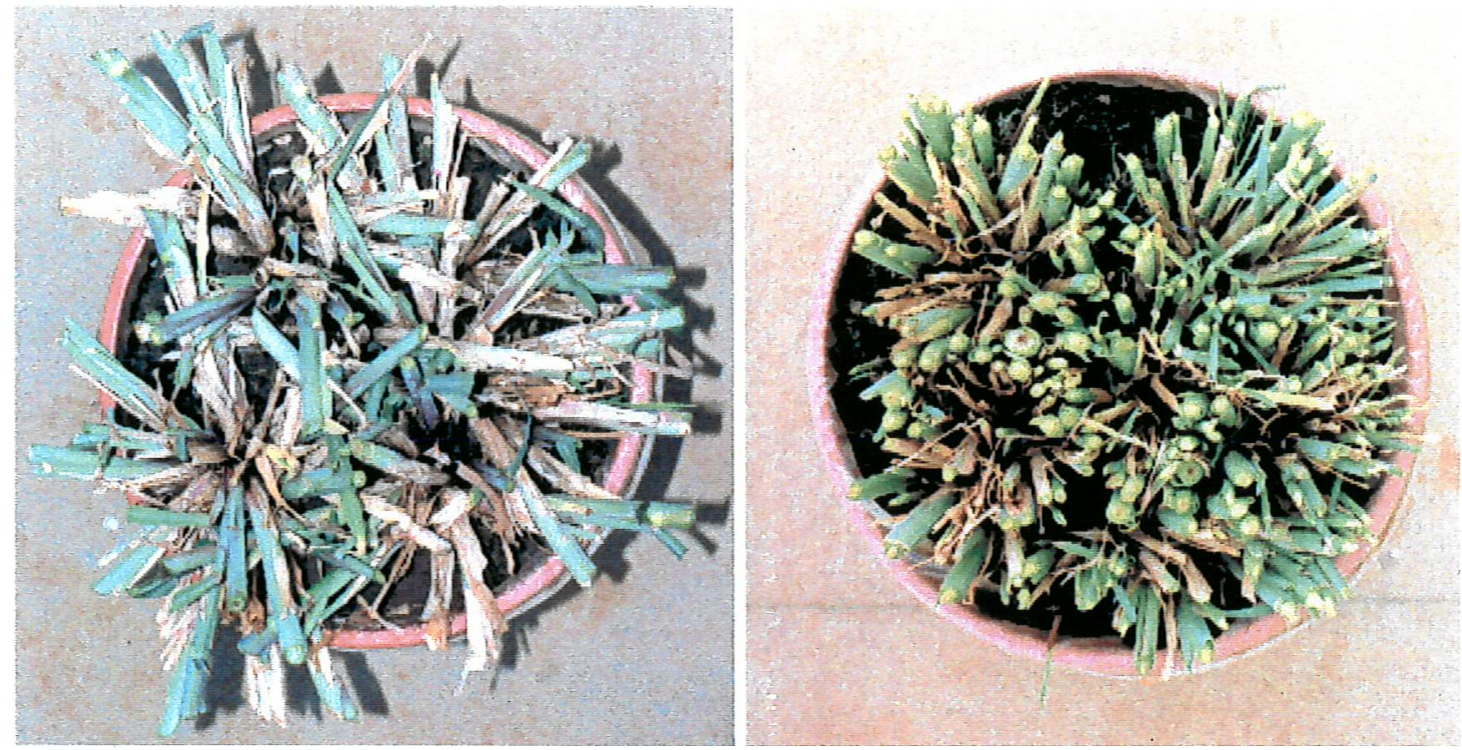

Figura 18 e 19- Detalhe dos vasos após o terceiro corte das espécies $E$. polystachya (esquerda) e E. pyramidalis (direita).
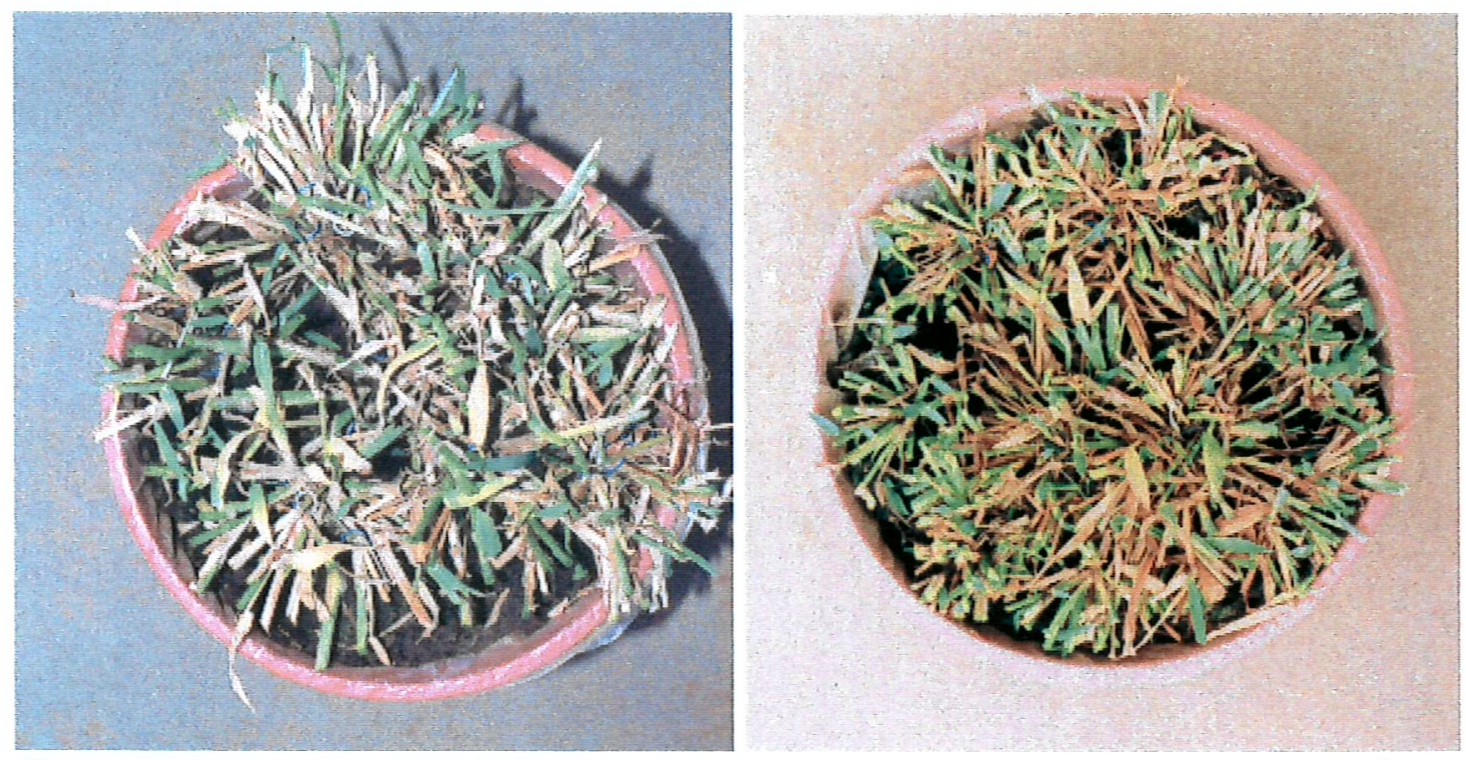

Figura 20 e 21- Detalhe dos vasos após o terceiro corte das espécies $B$. mutica (esquerda) e B. humidicola (direita). 


\section{RESULTADOS E DISCUSSÃO}

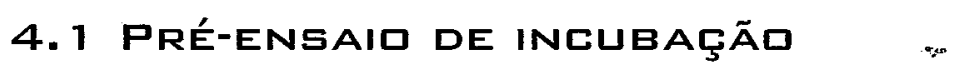

O comportamento do $\mathrm{pH}$ durante todo o período de incubação, determinado em $\mathrm{H}_{2} \mathrm{O}$ e em solução de $\mathrm{CaCl}_{2}$, estão apresentados graficamente para o solol (Figuras 22 e 23), e para o solo2 (Figuras 24 e 25). De modo justamente inverso, como era de se esperar, se comportou a acidez potencial $(\mathrm{H}+\mathrm{Al})$, ou seja, reduzindo-se ao longo do tempo (Figuras 26 e 27).

Como se pode observar nas Figuras 22 a 25, no quinto dia de incubação, a grande maioria do calcário já havia reagido, e a partir do $15-20^{\circ}$ dia o $\mathrm{pH}$ de ambos os solos praticamente se estabilizou até o momento do $40^{\circ}$ dia quando se optou por finalizar o ensaio. Este resultado mostra a elevada reatividade do calcário utilizado, deixando claro que, se condições ideais de homogeneização do calcário e quantidades adequadas de umidade no solo sejam satisfeitas durante o período de incubação, tem-se uma rápida reação do corretivo ao solo.

Analisando as curvas de $\mathrm{pH}$ ao longo do periodo de incubação, observa-se a existência de uma maior sinuosidade para as curvas obtidas com $\mathrm{pH}$ determinado em água em relação às obtidas em solução de cloreto de cálcio. Isto se deve à presença de sais interferindo nas determinações de $\mathrm{pH}$ em água, levando a uma maior variação nos resultados, do que nos determinados em uma solução já saturada com $\mathrm{CaCl}_{2}$. Fenômeno este explicado por Raij et al.(1987) e Quaggio (1986). 


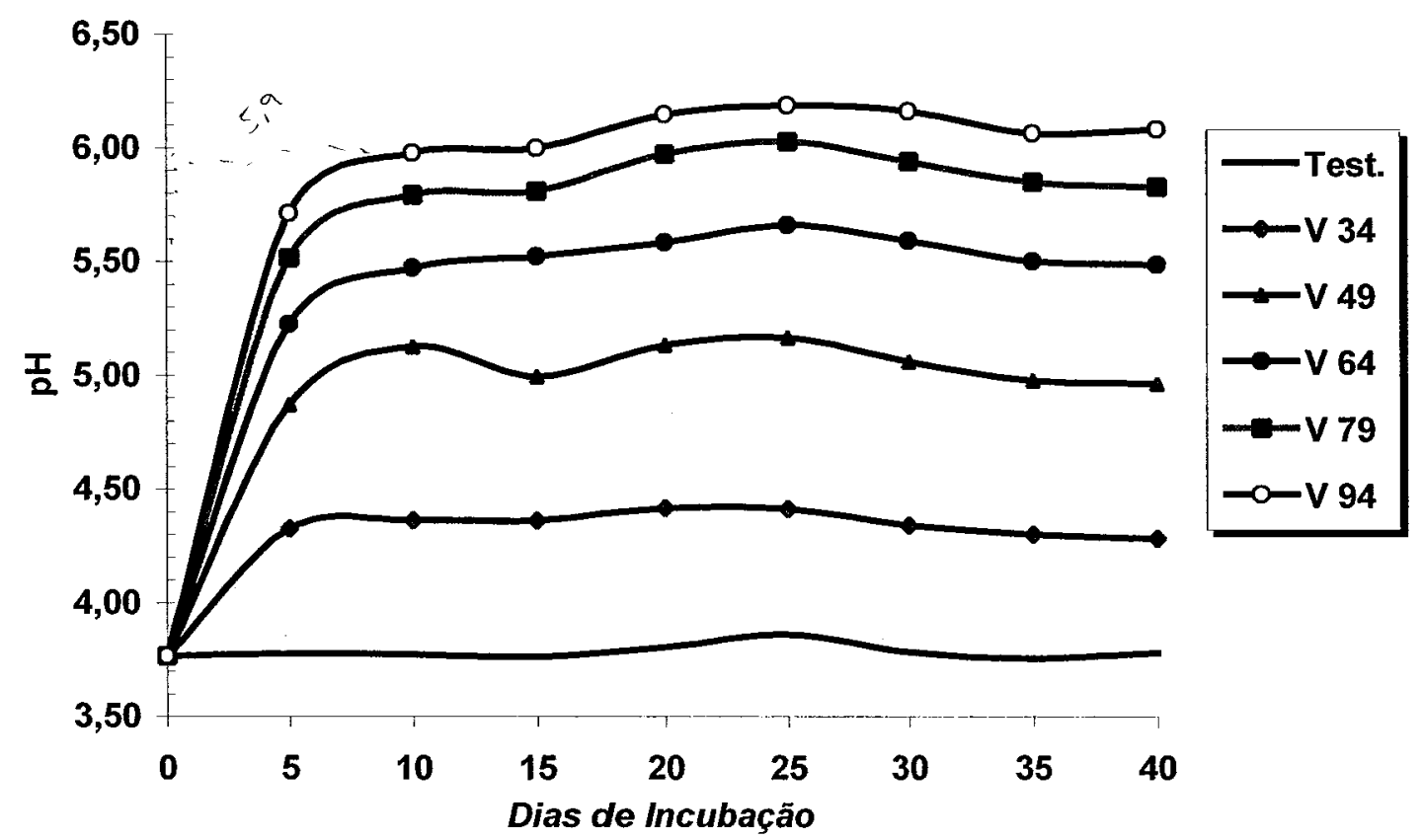

Figura 22- Variação do $\mathrm{pH}$ medido em $\mathrm{CaCl}_{2}$, durante o periodo de incubação do solo 1 .

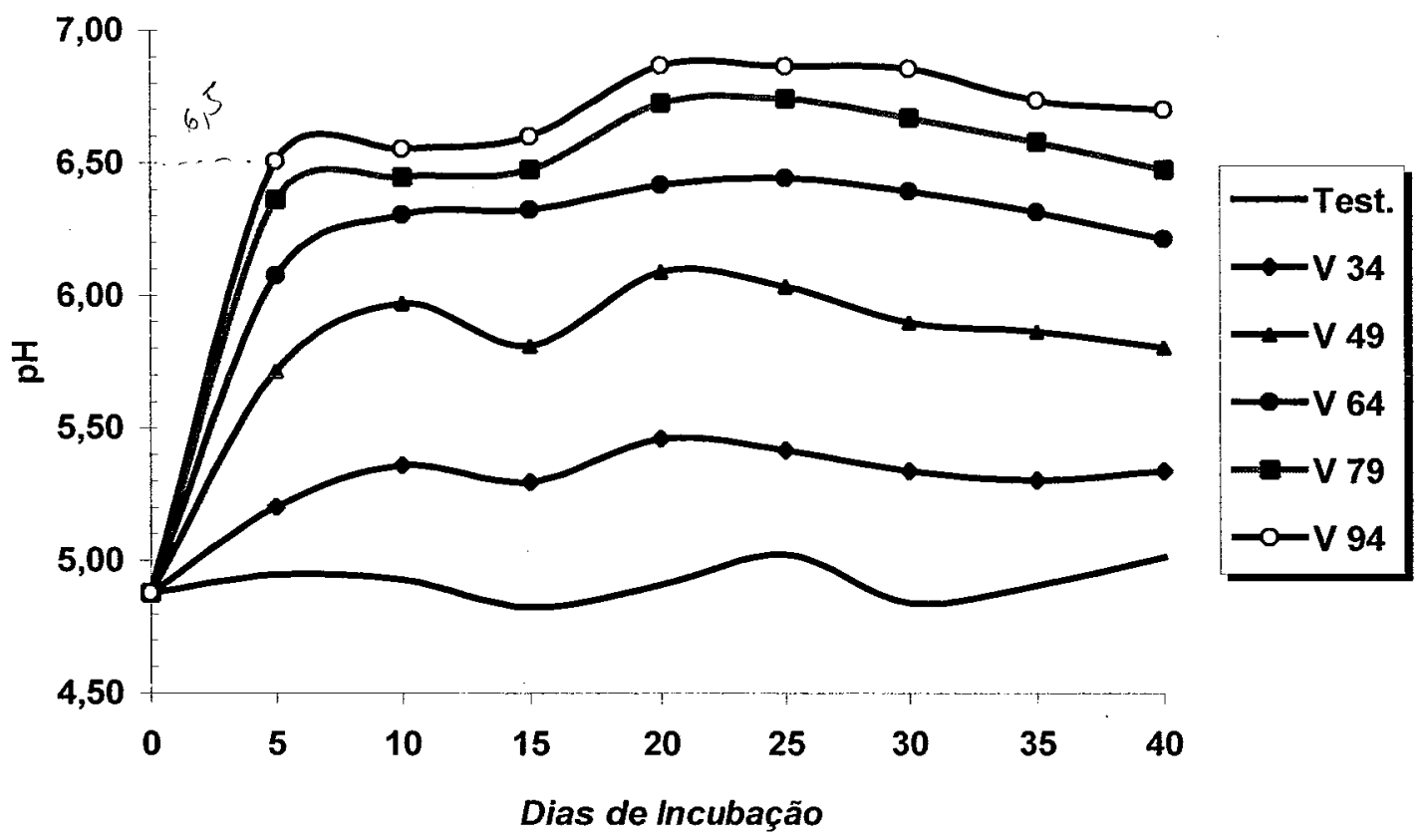

Figura 23- Variação do $\mathrm{pH}$ medido em $\mathrm{H}_{2} \mathrm{O}$, durante o período de incubação do solo 1. 


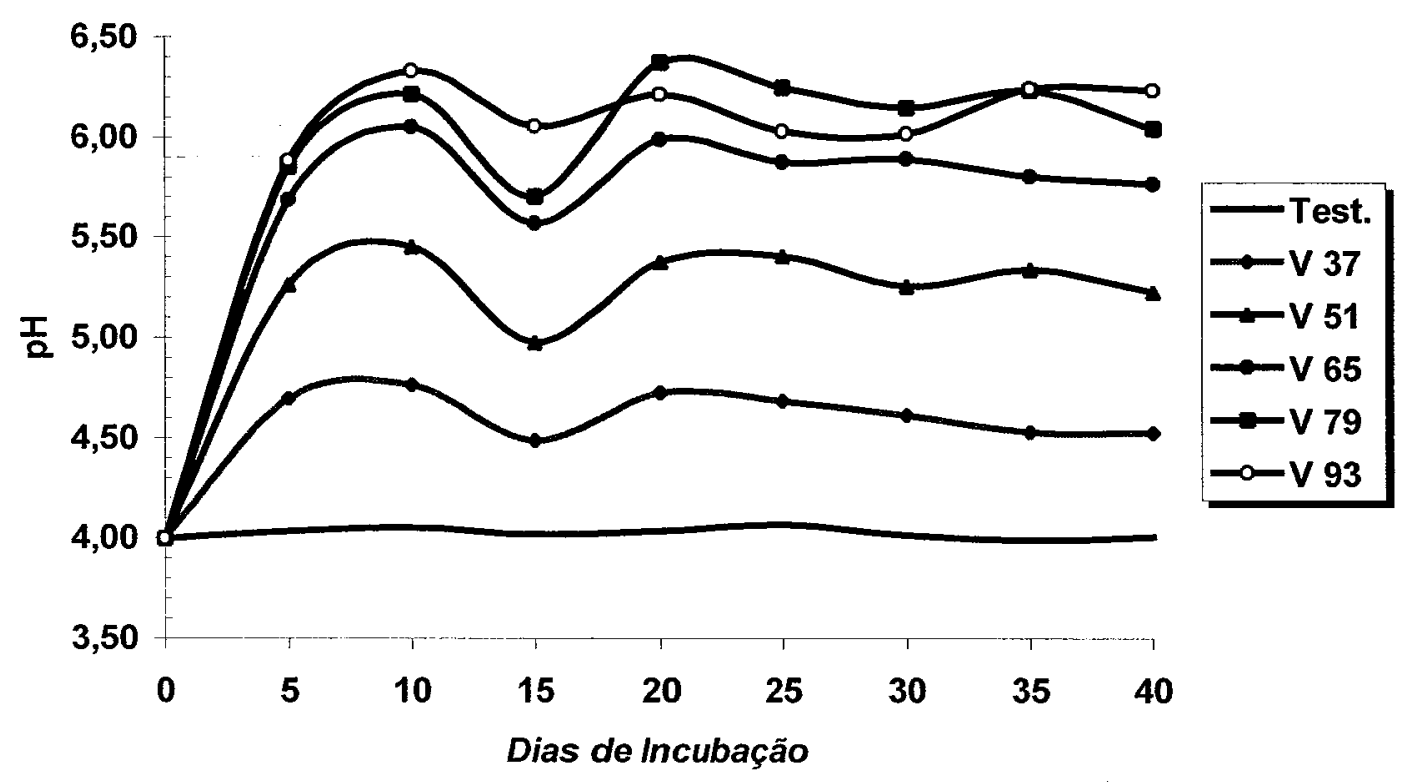

Figura 24- Variação do $\mathrm{pH}$ medidoem $\mathrm{CaCl}_{2}$, durante o periodo de incubação do solo 02.

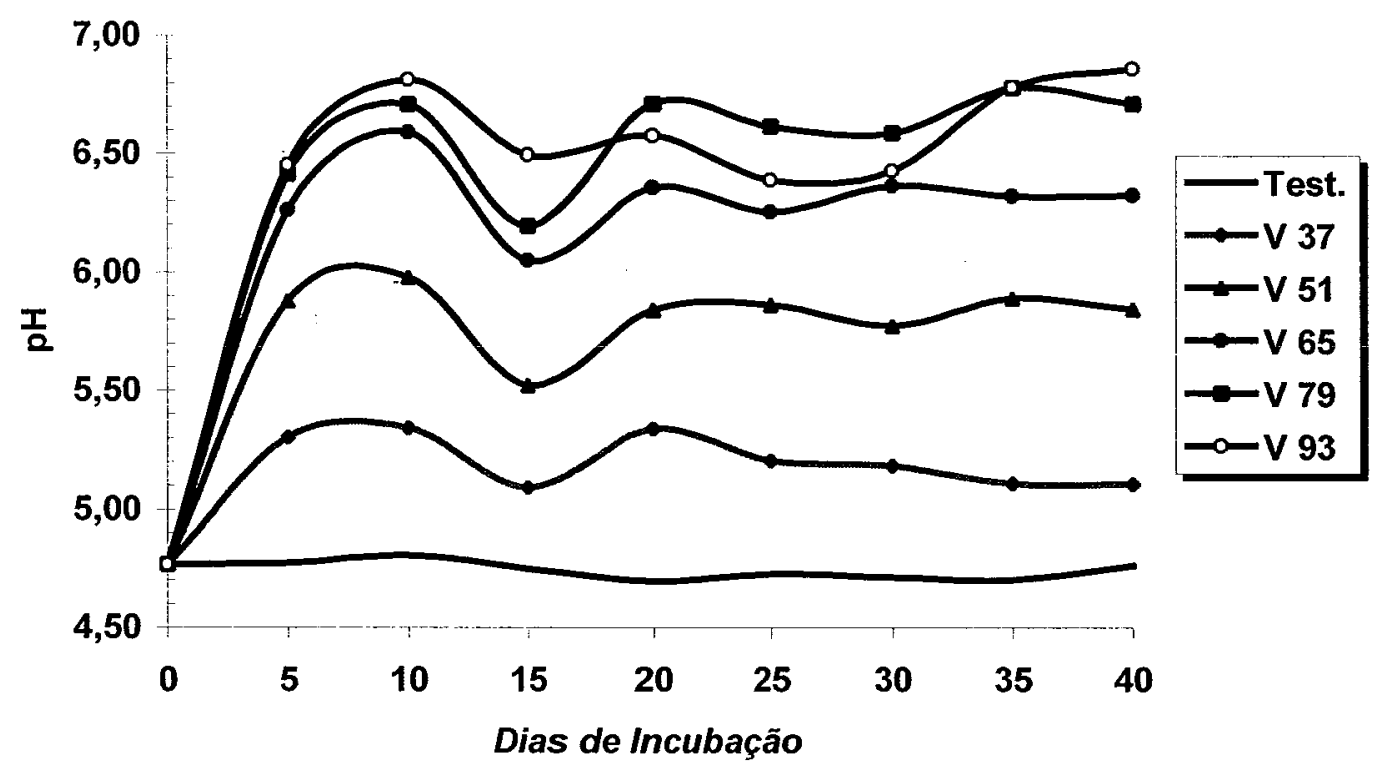

Figura 25- Variação do $\mathrm{pH}$ medido em $\mathrm{H}_{2} \mathrm{O}$, durante o período de incubação do solo 02 


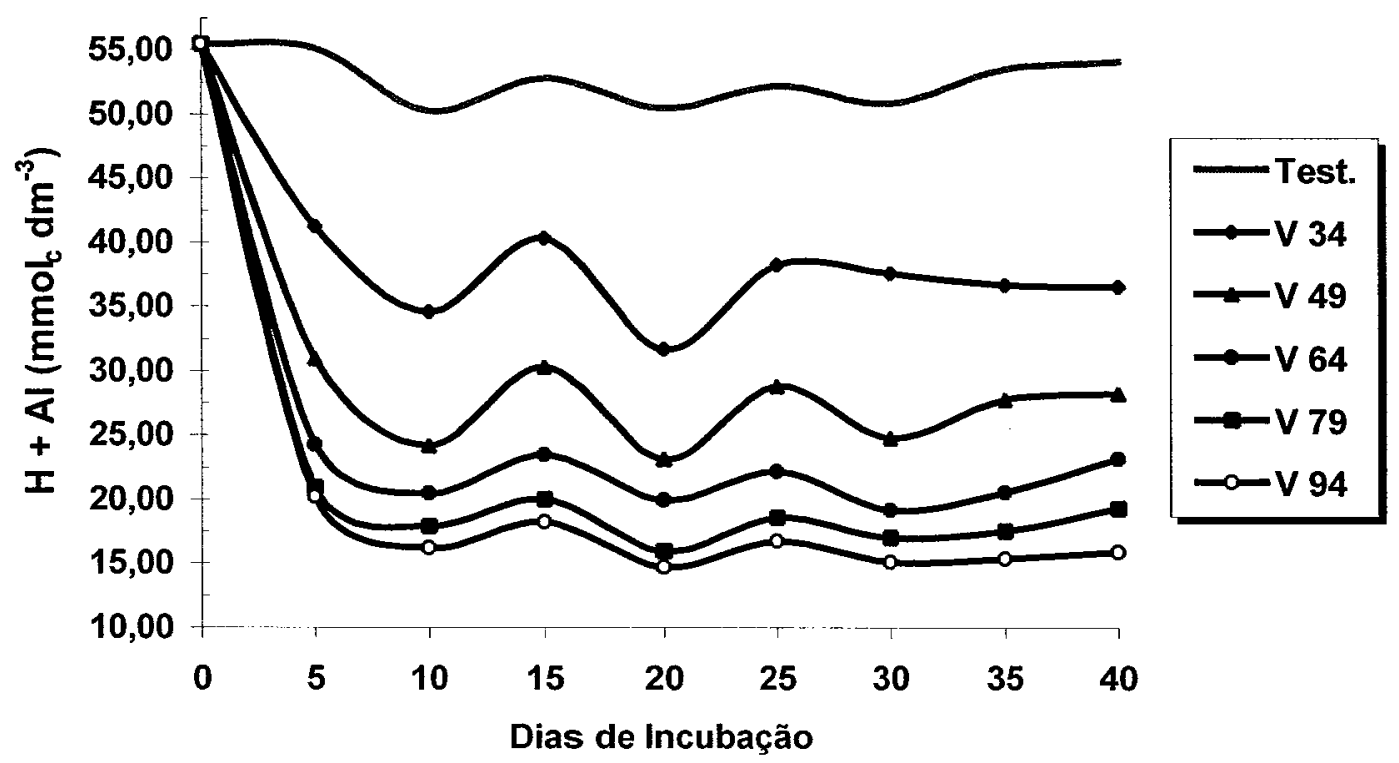

Figura 26- Variação da acidez potencial $(\mathrm{H}+\mathrm{Al})$ no período de incubação do solo 01.

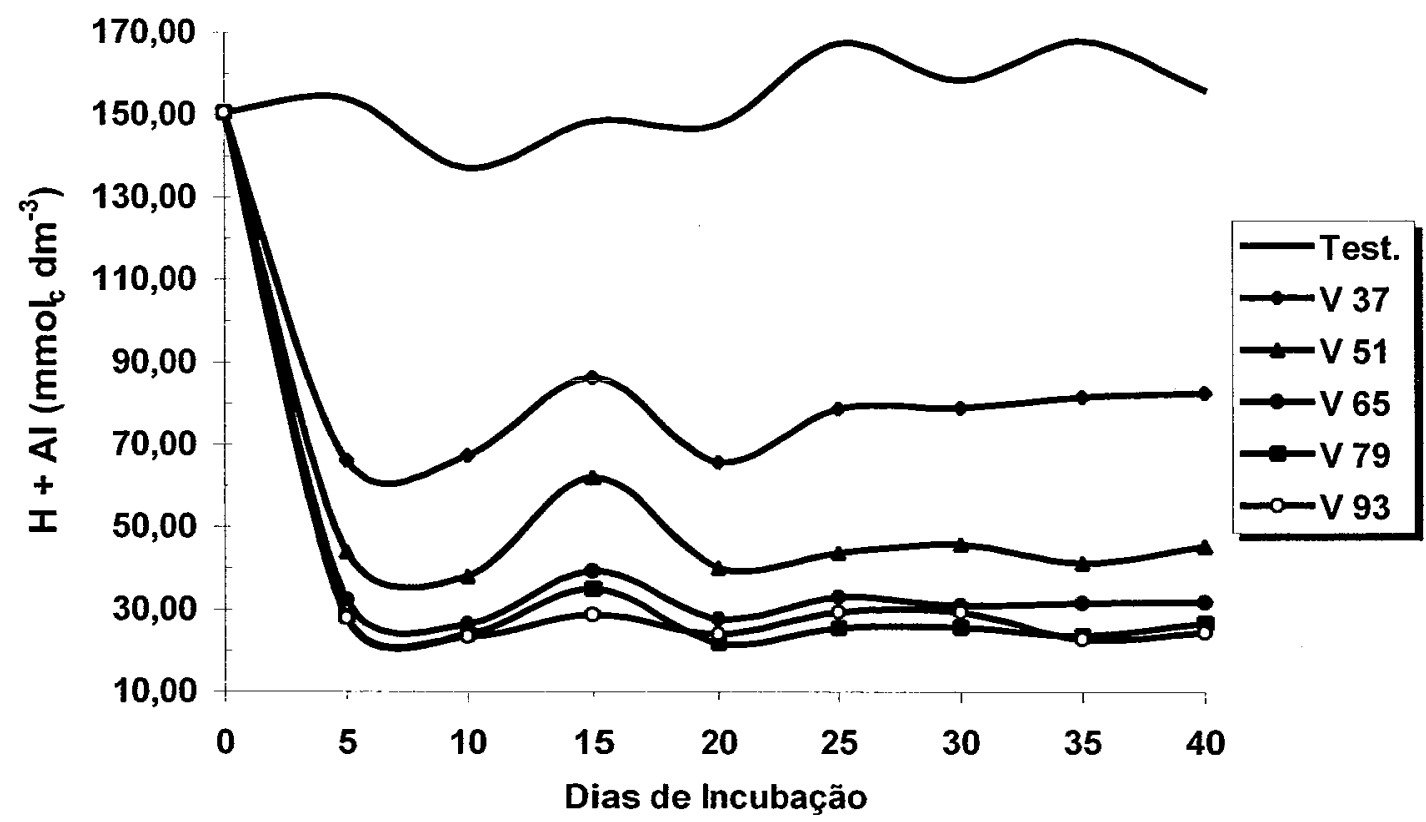

Figura 27- Variação da acidez potencial $(\mathrm{H}+\mathrm{Al})$ no período de incubação do solo 02. 
Devido ao grande número de observações geradas com a leitura de $\mathrm{pH}$ (quase mil leituras), procurou-se relacioná-las. Com isto, foram obtidos ótimos coeficientes de determinação ao relacionarmos $\mathrm{pH}$ em $\mathrm{H}_{2} \mathrm{O}$ e $\mathrm{CaCl}_{2}$, em ambos os solos avaliados (Figura 27 e 28). Sendo também possível a obtenção de ótimas equações, as quais explicam a variação da acidez potencial de cada solo em função do $\mathrm{pH}$ determinado em $\mathrm{CaCl}_{2}$ (Figuras 29 e 30).

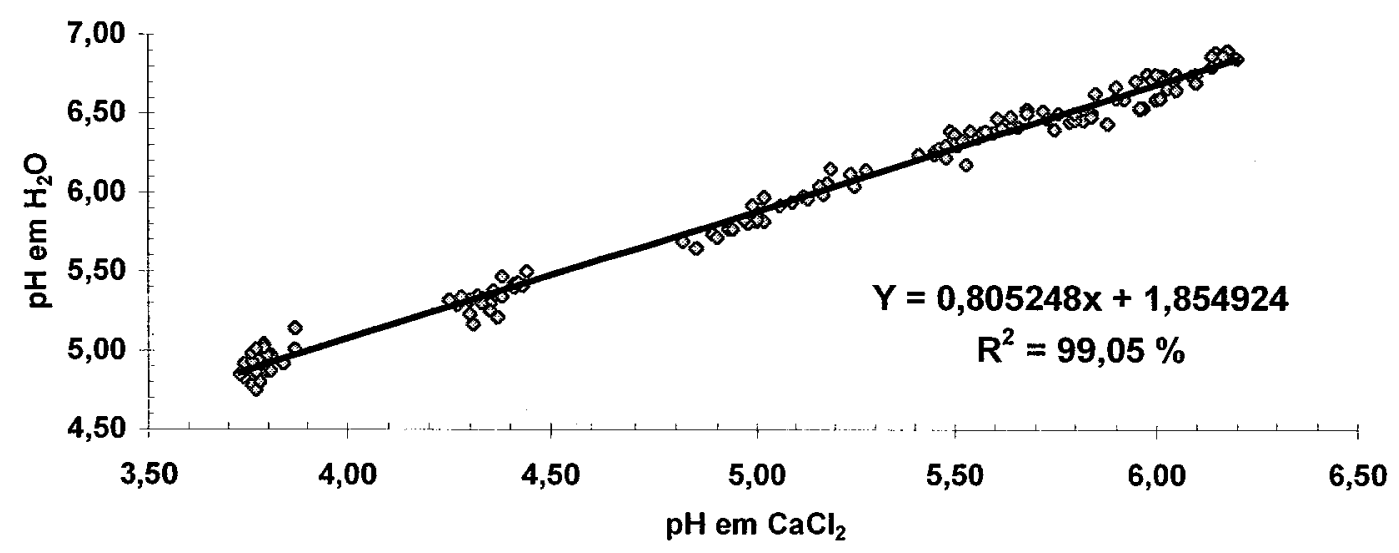

Figura 27- Relação entre $\mathrm{pH}\left(\mathrm{CaCl}_{2}\right)$ e $\mathrm{pH}\left(\mathrm{H}_{2} \mathrm{O}\right)$ no solo1.

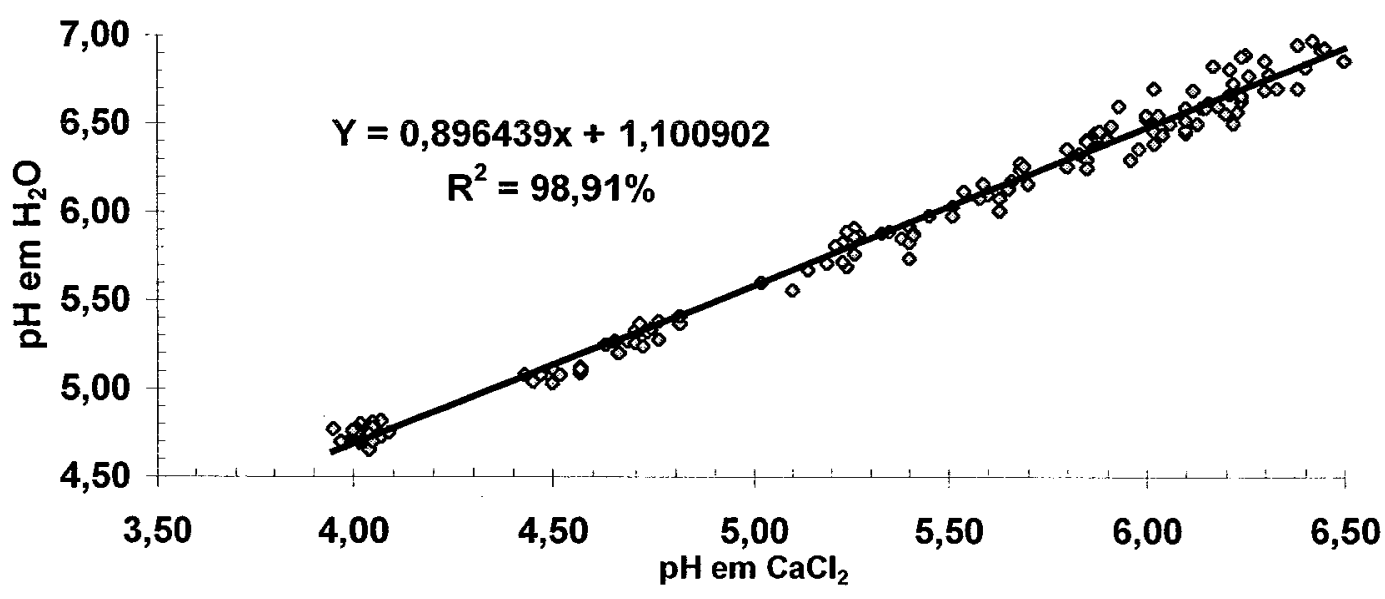

Figura 28- Relação entre $\mathrm{pH}\left(\mathrm{CaCl}_{2}\right)$ e $\mathrm{pH}\left(\mathrm{H}_{2} \mathrm{O}\right)$ no solo2. 


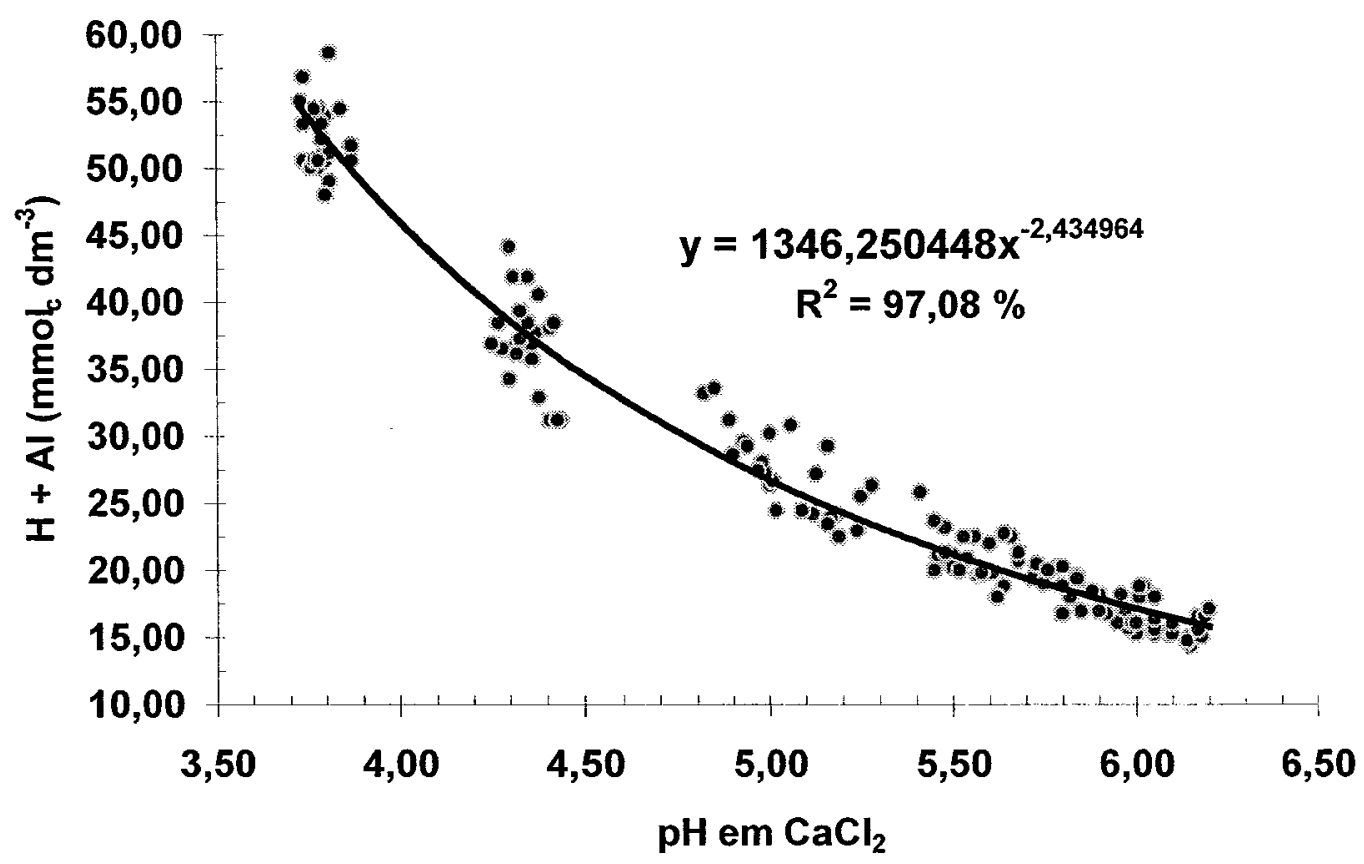

Figura 29- Relação entre $\mathrm{pH}\left(\mathrm{CaCl}_{2}\right)$ e acidez potencial $(\mathrm{H}+\mathrm{Al})$ no solo1.

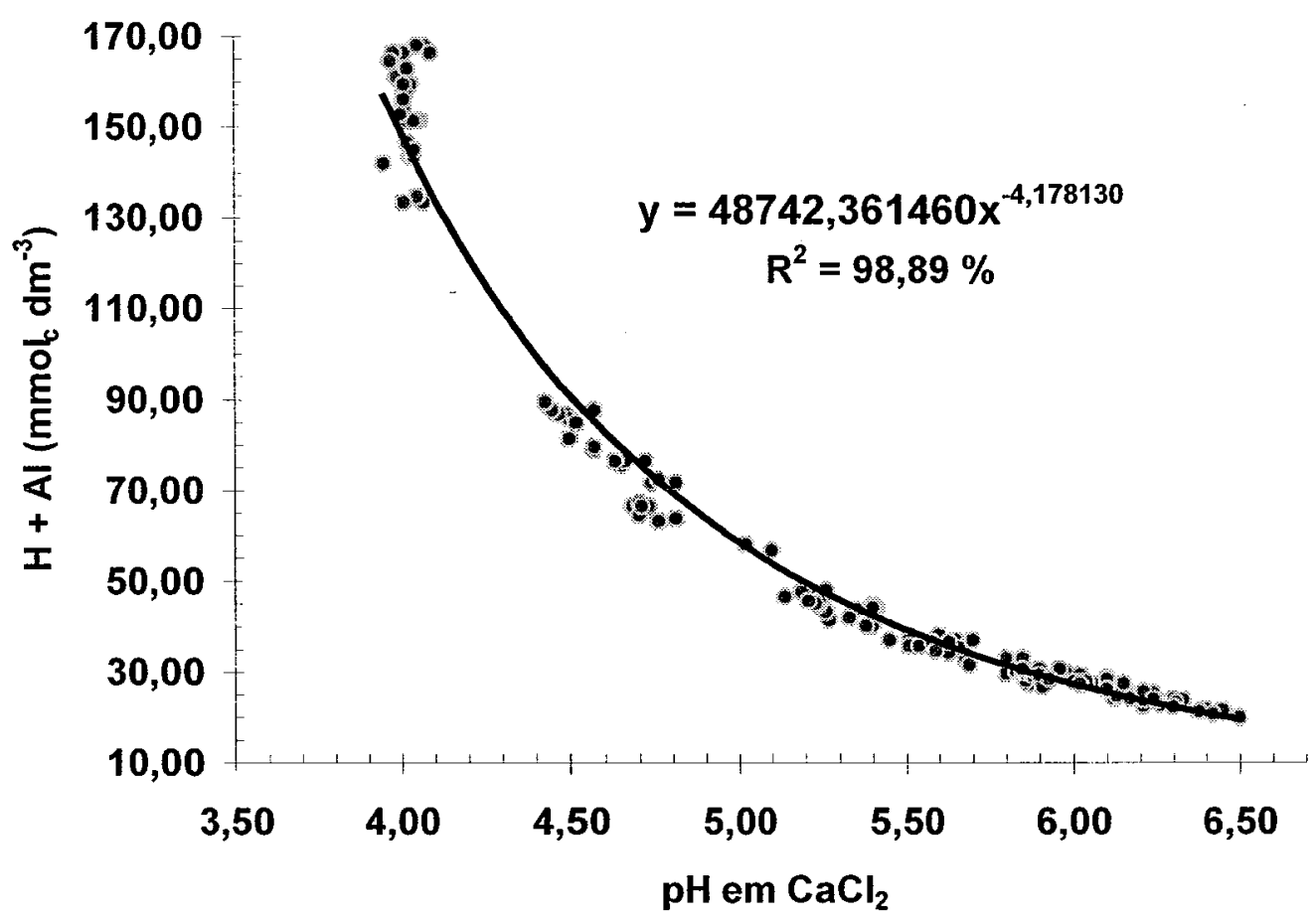

Figura 30- Relação entre $\mathrm{pH}\left(\mathrm{CaCl}_{2}\right)$ e acidez potencial $(\mathrm{H}+\mathrm{Al})$ no solo2. 
Então, a partir do conhecimento de como se comportaram os solos em diferentes valores de $\mathrm{pH}$, pode-se através das equações geradas, somente com o valor de $\mathrm{pH}$ em $\mathrm{CaCl}_{2}$, se obter com grande precisão qual seria o $\mathrm{pH}$ em $\mathrm{H}_{2} \mathrm{O}$ e a acidez potencial.

Os resultados das análises dos solos ao final do período de pré-incubação estão apresentados na Tabela 18, sendo os resultados estatísticos indicados nas Tabelas 19 e 20. No presente momento irá se discutir especificamente os resultados que afetam diretamente a obtenção das equações que relacionem as doses de calcário aplicadas e os respectivos valores de saturações por bases alcançadas para ambos os solos. Os demais parâmetros analisados serão discutidos no momento da apresentação dos resultados da incubação definitiva que foi realizada nos vasos, já que os mesmos tiveram. comportamento bem semelhante aos aqui encontrados.

Tabela 18 - Análise química dos solos realizada ao final do período de pré-incubação $\left(40^{\circ} \mathrm{dia}\right)$, valores médios de 3 repetições.

\begin{tabular}{|c|c|c|c|c|c|c|c|c|c|c|c|c|}
\hline \multirow{2}{*}{\multicolumn{2}{|c|}{$\begin{array}{l}\text { Solos } \\
\text { Trat. }\end{array}$}} & \multicolumn{2}{|c|}{$\mathrm{pH}$} & \multirow{2}{*}{$\begin{array}{c}\mathrm{MO} \\
\mathrm{g} \mathrm{dm^{-3 }}\end{array}$} & \multirow{2}{*}{$\begin{array}{c}\mathbf{P} \\
\mathrm{mg} \mathrm{dm}^{-3}\end{array}$} & \multirow[t]{2}{*}{ K } & \multirow[t]{2}{*}{$\mathrm{Ca}$} & \multirow{2}{*}{\multicolumn{2}{|c|}{$\begin{array}{l}\text { Mg } \quad \mathrm{H}+\mathbf{A l} \\
\mathrm{mmol}_{\mathrm{c}} \mathrm{dm}^{-3}\end{array}$}} & \multirow[t]{2}{*}{ SB } & \multirow[t]{2}{*}{ CTC } & \multirow{2}{*}{$\begin{array}{l}\mathbf{V} \\
\%\end{array}$} \\
\hline & & $\left(\mathrm{CaCl}_{2}\right)$ & $\left(\mathrm{H}_{2} \mathrm{O}\right)$ & & & & & & & & & \\
\hline \multirow{6}{*}{$\frac{5}{\circ}$} & $T$ & 3,78 & 5,01 & 25,22 & 8,79 & 3,23 & 0,9 & 2,7 & 54,07 & 6,9 & 61,0 & 11,3 \\
\hline & 34 & 4,28 & 5,34 & 25,22 & 9,65 & 3,26 & 6,0 & 9,0 & 36,50 & 18,2 & 54,7 & 33,3 \\
\hline & 49 & 4,96 & 5,80 & 24,69 & 11,63 & 3,16 & 10,1 & 12,8 & 28,26 & 26,0 & 54,3 & 48,0 \\
\hline & 64 & 5,49 & 6,21 & 25,76 & 11,81 & 3,53 & 14,1 & 17,0 & 23,13 & 34,6 & 57,8 & 60,0 \\
\hline & 79 & 5,83 & 6,47 & 24,69 & 13,36 & 3,10 & 18,6 & 19,1 & 19,28 & 40,9 & 60,1 & 67,9 \\
\hline & 94 & 6,08 & 6,70 & 23,61 & 13,96 & 3,36 & 21,0 & 21,7 & 15,89 & 46,2 & 62,0 & 74,4 \\
\hline \multirow{6}{*}{$\frac{\text { ํ }}{\text { ᄋ }}$} & $T$ & 4,01 & 4,76 & 31,13 & 2,24 & 2,60 & 2,1 & 16,1 & 156,09 & 20,8 & 176,9 & 11,8 \\
\hline & 37 & 4,52 & 5,10 & 33,27 & 2,24 & 2,96 & 15,2 & 42,7 & 82,53 & 60,9 & 143,4 & 42,5 \\
\hline & 51 & 5,23 & 5,84 & 31,66 & 3,10 & 2,23 & 29,8 & 62,8 & 45,37 & 94,8 & 140,2 & 67,6 \\
\hline & 65 & 5,76 & 6,32 & 26,83 & 4,31 & 1,63 & 39,4 & 69,2 & 31,67 & 110,3 & 142,0 & 77,7 \\
\hline & 79 & 6,04 & 6,71 & 26,83 & 4,31 & 1,46 & 58,4 & 80,5 & 27,6 & 140,4 & 168,0 & 83,6 \\
\hline & 93 & 6,23 & 6,86 & 27,37 & 4,39 & 1,66 & 69,5 & 89,0 & 25,7 & 160,2 & 185,9 & 86,2 \\
\hline
\end{tabular}

O maior objetivo deste ensaio de incubação foi obter o comportamento dos solos em função das dosagens crescentes de calcário, para que na execução da calagem definitiva nos vasos, onde foram plantadas as forrageiras, realmente se alcançasse com maior precisão possível o valor de saturação por bases previamente estipulada pelos tratamentos. Ao analisarmos os dados deste pré-ensaio, observamos que o valor da CTC de ambos os solos sofreu mudanças com os tratamentos (Figura 31 e 32), o que não era 
de se esperar, pois por definição a CTC total de um solo a pH 7,0 não deve mudar independente do $\mathrm{pH}$ em que o solo se encontre no momento de sua determinação. Segundo Raij (1991) a CTC de um solo tem valor constante dentro de condições padronizadas de determinação, tratando-se de uma característica inalterável em curto prazo por práticas agrícolas. Logo, este efeito observado, mostrando variação na CTC se deve provavelmente ao método indireto por qual a mesma é obtida, ou seja, pela soma das bases e da acidez potencial do solo, o que acaba por acumular os possíveis erros na determinação de cada base e principalmente na quantificação da acidez potencial,-que já é determinada indiretamente pelo método de $\mathrm{pH}$ em SMP.

Tabela 19- Resultados estatísticos do pré-ensaio de incubação no solo 1

\begin{tabular}{|c|c|c|c|c|c|c|c|}
\hline \multirow[b]{2}{*}{ Variável } & \multirow[b]{2}{*}{$\mathbf{F}$} & \multicolumn{3}{|c|}{$\operatorname{Reg.~} 1^{\circ}$} & \multicolumn{3}{|c|}{$\operatorname{Reg.~} 2^{\circ}$} \\
\hline & & Sig. & Equação & $\mathbf{R}^{2}$ & Sig. & Equacão & $\mathbf{R}^{2}$ \\
\hline $\mathrm{pH}\left(\mathrm{H}_{2} \mathrm{O}\right)$ & ** & $* *$ & $4,6046+0,0233 v$ & 0,98 & $* *$ & $4,3410+0,0351 v-0,0001 v^{2}$ & 0,99 \\
\hline $\mathrm{pH}\left(\mathrm{CaCl}_{2}\right)$ & ** & ** & $3,2765+0,0318 v$ & 0,97 & ** & $2,7546+0,0550 v-0,0002 v^{2}$ & 0,99 \\
\hline M.O. & n.s. & - & - & - & - & - & - \\
\hline$P$ & $\pm * *$ & ** & $7,5240+0,0707 v$ & 0,85 & n.s. & - & - \\
\hline $\mathrm{K}$ & n.s & - & - & - & - & - & - \\
\hline $\mathrm{Ca}$ & $* *$ & $* *$ & $-3,5497+0,2719 v$ & 0,98 & n.s. & - & - \\
\hline $\mathrm{Mg}$ & ** & ** & $-0,2324+0,2470 v$ & 0,89 & n.s. & - & - \\
\hline $\mathrm{H}+\mathrm{Al}$ & ** & ** & $56,1994-0,4721 v$ & 0,89 & ** & $74,0386-1,2670 v+0,0070 v^{2}$ & 0,98 \\
\hline CTC & ** & n.s. & - & - & ** & $66,0613-0,4176 v+0,0041 v^{2}$ & 0,56 \\
\hline V & ** & ** & $2,7182+0,8210 \mathrm{v}$ & 0,95 & ** & $-18,3212+1,7585 v-0,0083 v^{2}$ & 0,99 \\
\hline
\end{tabular}

Tabela 20- Resultados estatísticos do pré-ensaio de incubação no solo 2

\begin{tabular}{|c|c|c|c|c|c|c|c|}
\hline \multirow[b]{2}{*}{ Variável } & \multirow[b]{2}{*}{$\mathbf{F}$} & \multicolumn{3}{|c|}{$\operatorname{Reg} .1^{\circ}$} & \multicolumn{3}{|c|}{$\operatorname{Reg} .2^{\circ}$} \\
\hline & & Sig. & Equação & $\mathbf{R}^{2}$ & Sig. & Equação & $\mathbf{R}^{2}$ \\
\hline $\mathrm{pH}\left(\mathrm{H}_{2} \mathrm{O}\right)$ & ** & ** & $4,0631+0,0322 v$ & 0,96 & ** & $3,4576+0,0574 v-0,0002 v^{2}$ & 0,98 \\
\hline $\mathrm{pH}\left(\mathrm{CaCl}_{2}\right)$ & ** & $* *$ & $3,3790+0,0331 \mathrm{v}$ & 0,95 & ** & $2,5335+0,0682 v-0,0003 v^{2}$ & 0,99 \\
\hline M.O. & ** & $* *$ & $34,5837-0,871 \mathrm{v}$ & 0,59 & n.s. & - & - \\
\hline$P$ & ** & ** & $1,2869+0,0370 \mathrm{v}$ & 0,84 & n.s. & - & - \\
\hline $\mathrm{K}$ & ** & ** & $3,2505-0,0199 v$ & 0,68 & n.s. & - & - \\
\hline $\mathrm{Ca}$ & ** & ** & $-20,630+0,97197 v$ & 0,98 & ** & $-18,5863+0,8871 v+0,0007 v^{2}$ & 0,98 \\
\hline $\mathrm{Mg}$ & ** & ** & $2,7390+0,9885 v$ & 0,92 & ** & $-29,2734+2,1383 v-0,0115 v^{2}$ & 0,97 \\
\hline $\mathrm{H}+\mathrm{Al}$ & ** & $\star \star \star$ & $159,7779-1,6948 v$ & 0,76 & $* \star$ & $284,6731-6,8833 v+0,0447 v^{2}$ & 0,98 \\
\hline CTC & ** & n.s. & - & - & ** & $240,4011-3,7112 v+0,0341 v^{2}$ & 0,84 \\
\hline $\mathrm{V}$ & 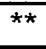 & 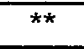 & $1,7073+1,0313 v$ & 0,86 & ** & $-53,4814+3,3240 v-0,0198 v^{2}$ & 0,99 \\
\hline
\end{tabular}

**-Significativo pelo teste $F$ ao nivel de $1 \%$ de probabilidade; n.s. - Não significativo ; $v$ - das equações se refere ao valor de $\mathrm{V}$ desejado, que foi aplicado (tratamentos). 


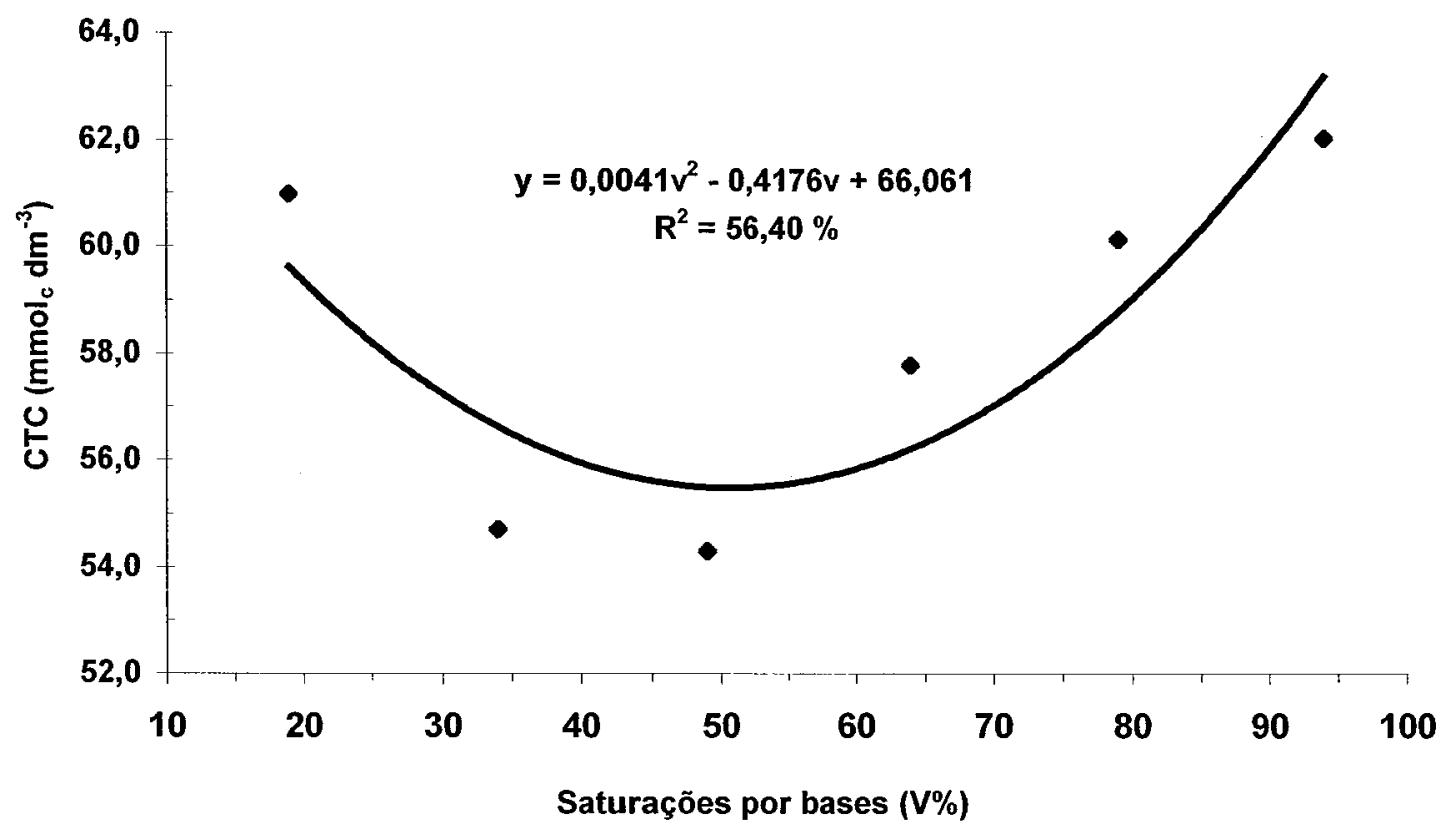

Figura 31- Variação na determinação da CTC no solo 1.

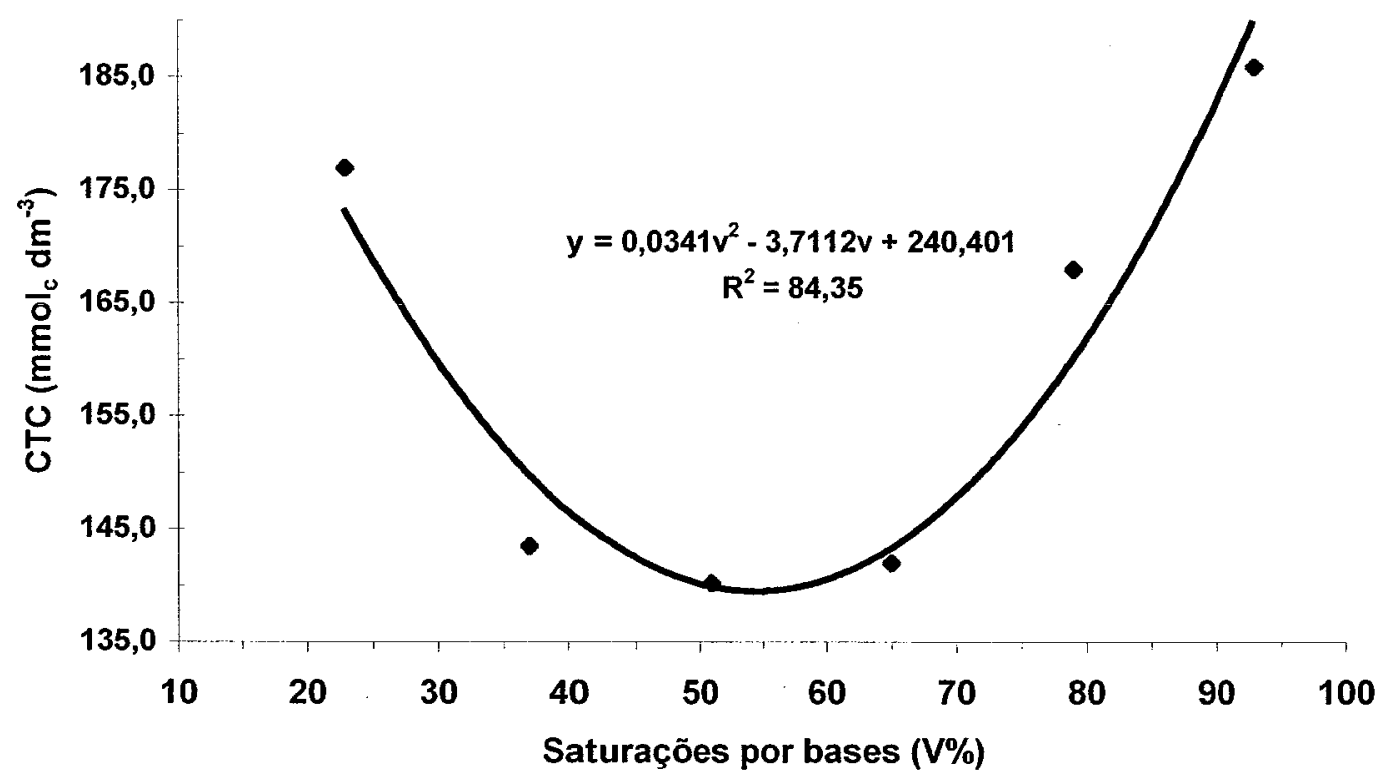

Figura 32- Variação na determinação da CTC no solo 2. 
Procurando contornar o problema constatado na determinação da CTC dos solos, realizou-se novamente a regressão dos dados. Desta vez porém, utilizou-se para cálculo das saturações por bases alcançadas um valor médio de CTC $\left(58,0\right.$ e $156,0 \mathrm{mmol}_{\mathrm{c}} \mathrm{dm}^{-3}$ para o solo1 e solo 2, respectivamente), que passou a se chamar CTCf (CTC fixa), e tomou-se como variável independente a quantidade de calcário aplicada ao solo em $\mathrm{mg}$ $\mathrm{kg}^{-1}$, ao invés do valor de saturação por base estipulada para cada tratamento. Obtendose assim, os resultados apresentados nas Figuras 33 e 34, que mostram matematicamente o comportamento das doses crescentes de calcário em relação as saturações por bases alcançadas.

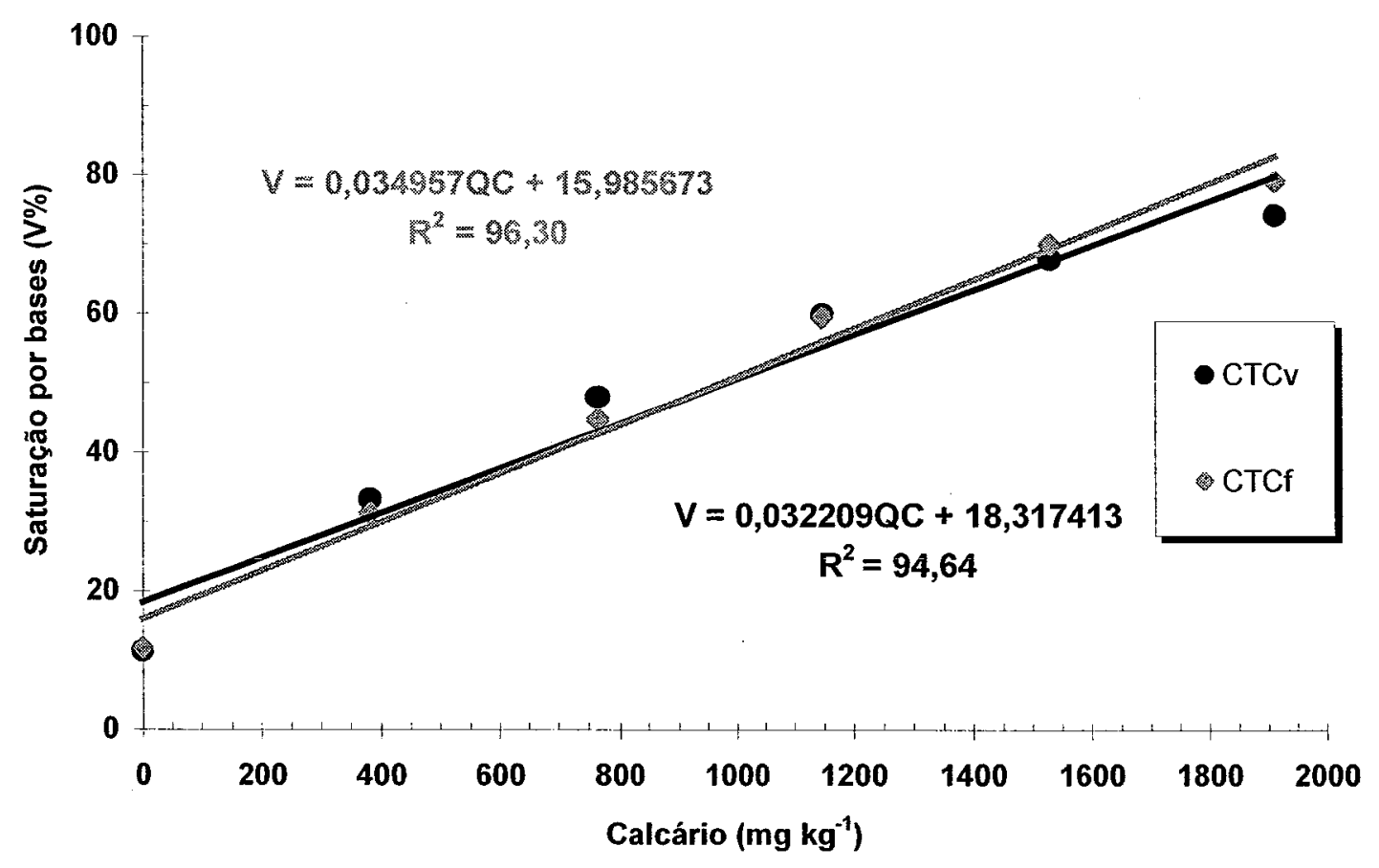

Figura 33- Equação de ajuste de calagem para o solo 1, onde QC é a quantidade de calcário. CTCV- CTC calculada a cada tratamento; CTCf- CTC média dos tratamentos. 


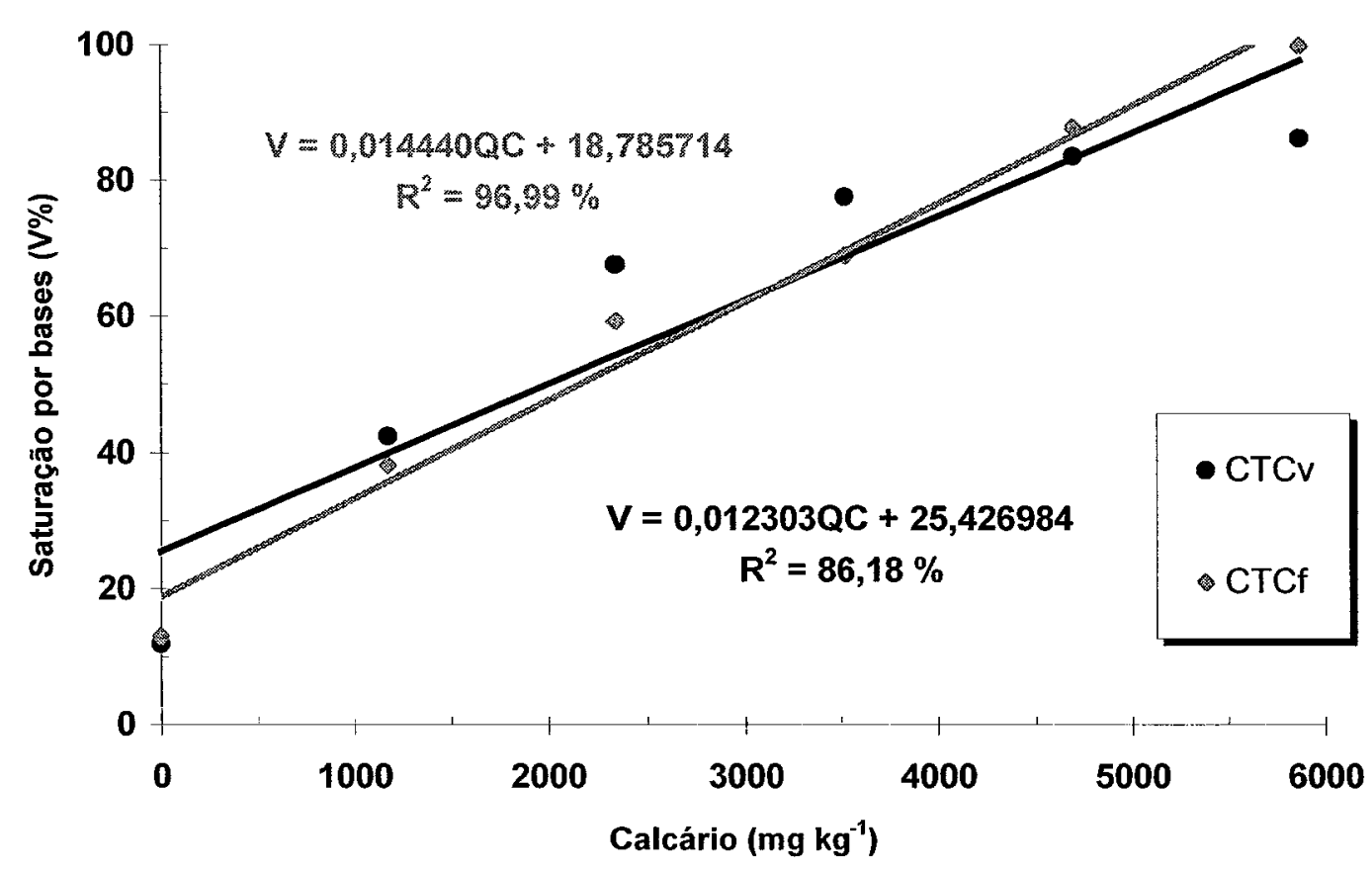

Figura 34- Equação de ajuste de calagem para o solo 2, onde $Q C$ é a quantidade de calcário. CTCV- CTC calculada a cada tratamento; CTCf- CTC média dos tratamentos.

Mesmo obtendo-se, estatisticamente, melhor ajuste quando se utilizam equações de $2^{\mathbf{o}}$ grau para demonstrar a resposta dos solos à doses crescentes de calcário, optou-se pela equação do $1^{\circ}$ grau, pois não teria como explicar cientificamente um comportamento quadrático para saturação de bases de um solo frente a doses crescentes de calcário. Optou-se por adotar as equações que utilizaram os valores de CTC fixa (CTCf), pelo já discutido anteriormente, e ainda por estas apresentarem equações com melhores coeficientes de determinação. Logo, foram estas as equações utilizadas para se realizar a incubação definitiva nos vasos do experimento.

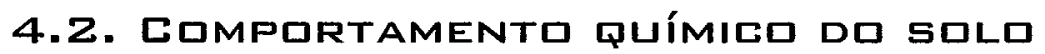

Os resultados das análises de solo após o período de incubação definitiva, e após cada corte das forrageiras estão apresentados nas Tabelas 22 a 35, sendo que as 
equações de regressão obtidas para os parâmetros que foram significativos estão apresentadas no Anexo - Tabelas 1 a 4.

\subsubsection{SATURAÇŨES PLR BASES PRETENDIDAS VERSUS ALCANÇADAS}

Ao observar os resultados das análises de solo o primeiro parâmetro que se buscou confrontar foram as saturações por bases atingidas para cada tratamento em relação às previamente estipuladas, buscando-se verificar a efetividade das equações geradas no pré-ensaio de incubação (Tabela 21).

Tabela 21 - Confronto entre os valores desejados de saturações por bases e os realmente alcançados para os distintos tratamentos após a incubação definitiva.

\begin{tabular}{|c|c|c|c|c|c|c|}
\hline \multicolumn{2}{|c|}{ Tratamentos } & \multirow{2}{*}{$\begin{array}{c}\text { V desejado } \\
10\end{array}$} & \multirow{2}{*}{$\frac{\mathbf{V} \mathbf{v}^{\mathbf{1}}}{9,26}$} & \multirow{2}{*}{$\begin{array}{c}\text { Diferença } \\
-0,74\end{array}$} & \multirow{2}{*}{$\frac{\text { Vf }^{2}}{9,91}$} & \multirow{2}{*}{$\begin{array}{c}\text { Diferença } \\
-0,09\end{array}$} \\
\hline \multirow{6}{*}{ 응 } & $\mathbf{T}$ & & & & & \\
\hline & V30 & 30 & 35,49 & $+5,49$ & 29,58 & $-0,42$ \\
\hline & V50 & 50 & 54,21 & $+4,21$ & 48,28 & $-1,72$ \\
\hline & V70 & 70 & 68,49 & $-1,51$ & 66,68 & $-3,32$ \\
\hline & V90 & 90 & 75,87 & $-14,13$ & 87,28 & $-2,72$ \\
\hline & & & Soma* $=$ & 26,08 & Soma $^{*}=$ & 8,27 \\
\hline \multirow{6}{*}{$\begin{array}{l}\text { N } \\
\text { 응 }\end{array}$} & $\mathbf{T}$ & 15 & 11,60 & $-3,40$ & 14,32 & $-0,68$ \\
\hline & V35 & 35 & 36,87 & $+1,87$ & 33,65 & $-1,35$ \\
\hline & V55 & 55 & 72,87 & $+17,87$ & 57,98 & $+2,98$ \\
\hline & V75 & 75 & 80,46 & $+5,46$ & 76,25 & $+1,25$ \\
\hline & V95 & 95 & 85,39 & $-9,61$ & 93,80 & $-1,2$ \\
\hline & & & Soma ${ }^{*}=$ & 38,21 & Soma ${ }^{*}=$ & 7,46 \\
\hline
\end{tabular}

${ }^{1-}$ Saturação por bases, considerado a CTC variável; ${ }^{1-}$ Saturação por bases, considerado a CTC média obtida; *-Soma absoluta dos valores.

Como pode ser verificado na Tabela 23, assim como ocorrido no pré-ensaio de incubação, novamente foi verificado um comportamento quadrático com ponto de mínima para a CTC do solo em função das doses crescentes de saturação por bases. Porém os valores médios de CTC obtidos nas duas incubações ficaram bem próximos, sendo de 58,0 e $156,0 \mathrm{mmol}_{\mathrm{c}} \mathrm{dm}^{-3}$ na pré-incubação e 57,1 e $155,6 \mathrm{mmol}_{\mathrm{c}} \mathrm{dm}^{-3}$ na incubação definitiva para o solo 1 e 2 respectivamente. Este tipo de comportamento da CTC, como discutido anteriormente, é provavelmente causado pela metodologia 
empregada para sua determinação, o que acaba por subestimar a saturação por bases nos tratamentos extremos (menores e maiores saturações) e superestimar os valores centrais como pode ser visualizado na Tabela 21. Logo, assim como foi realizado no pré-ensaio de incubação para se ajustar às curvas de necessidade de calcário, novamente calculouse as saturações alcançadas para cada tratamento na base da CTC média obtida na préincubação. Calculados desta forma, como pode ser visualizado na Tabela 21 , os valores de saturação atingidos e os pretendidos ficam bem mais próximos.

Em virtude dos melhores ajustes terem sido alcançados quando se calculou a saturação por bases levando-se em consideração a CTC média fixa, a partir de então para as demais análises de solo realizadas no decorrer do experimento, os valores de saturação alcançados foram sempre calculados desta forma.

\subsubsection{CALAGEM E DISPONIBIUDADE DQS NUTRIENTES APĆS A INCUBAÇÃa}

A análise do solo pós-incubação (Tabelas 22 e 23), mostra que a maioria dos parâmetros analisados tiveram um comportamento clássico frente a doses crescentes de calcário, sendo bem semelhantes aos já verificados no pré-ensaio de incubação, resultados estes que estão de acordo, com os dados amplamente discutidos na literatura por vários autores como Jorge (1983), Malavolta et al. (1989), Defelipo (1990) e Raij (1991).

Os teores de $\mathrm{Ca}$ e $\mathrm{Mg}$ foram crescentes em função das doses de calcário aplicadas ao solo em resposta direta do fornecimento destes nutrientes pelo corretivo, aumentos estes, explicados na sua quase totalidade por equações lineares, já que as quadráticas, mesmo quando estatisticamente significativas, pouco aumentaram os valores dos coeficientes de determinação. Em virtude deste comportamento a saturação por bases do solo também cresceu do mesmo modo. Outro aspecto que deve ser lembrado para estes solos é a relação $\mathrm{Ca}: \mathrm{Mg}$ dos mesmos, pois diferentemente da maioria dos solos brasileiros, estes possuem naturalmente mais $\mathrm{Mg}$ que $\mathrm{Ca}$ proporcionando deste modo relações Ca:Mg menores que 1. Apesar do calcário utilizado 
ser do tipo dolomítico, as doses crescentes deste causaram aumentos na relação $\mathrm{Ca} / \mathrm{Mg}$ do solo porém ficando sempre abaixo de 1 para todos os tratamentos em ambos os solos.

Alem do fornecimento de $\mathrm{Ca}$ e $\mathrm{Mg}$, a calagem foi efetiva em aumentar o $\mathrm{pH}$ do solo e reduzir o Al trocável pela ação neutralizante, reagindo com hidrogênio e precipitando o alumino na forma de hidróxido, tornado os teores de $\mathrm{Al}^{3+}$ nulos a partir da aplicação da terceira dose de calcário para ambos os solos.

Os teores naturais de fósforo nos solos foram favorecidos pela calagem, mostrando-se crescente em função das crescentes saturações por base, sendo este aumento explicados possivelmente pela liberação dos fosfatos que estavam ligados ao $\mathrm{Fe}$ e $\mathrm{Al}$, e que foram liberados por efeito de elevação de $\mathrm{pH}$.

Para o potássio não foram verificados efeitos significativos para o solo1, porém no solo2, este decresceu linearmente com as crescentes doses de calcário aplicadas ao solo, fenômeno este que pode ser explicado pela presença de argilas 2:1 neste solo, que segundo Barros (1990), em solos com este tipo de argila a calagem pode aumentar a "fixação" do K entre as unidades cristalográficas destes tipos de argila.

A matéria orgânica de ambos os solos foi reduzida significativamente para ambos os solo na incubação definitiva e somente no solo 2 durante o pré-ensaio, fenômeno este que pode ser explicado pelo favorecimento da mineralização do material orgânico pela ação positiva do aumento do $\mathrm{pH}$ na atividade microbiológica do solo. Esta mesma atividade pode também ter favorecido o aumento da disponibilidade de enxofre verificada para o solo 1 , que teve comportamento linear crescente e para o solo 2 que mostrou a mesma tendência, porém sem significância estatística. Lembrando ainda, que o aumento da disponibilidade do enxofre também pode ser causada pelo efeito do aumento do $\mathrm{pH}$ liberando sulfatos que estavam ligados a Fe e Al.

Quanto aos micronutrientes, não foi verificado efeito significativo para os teores de $\mathrm{B}$ e também para o $\mathrm{Cu}$ no solo 2. Para o $\mathrm{Cu}$ no solo 1 e ainda para o Fe, $\mathrm{Mn}$ e $\mathrm{Zn}$ de ambos os solos, foram verificados reduções significativas em seus teores com as crescentes saturações por bases estabelecidas nos solos. 


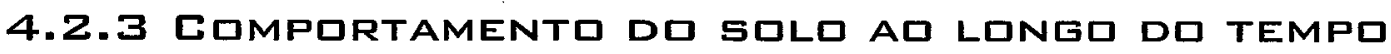

Realizado uma análise geral dos resultados das primeiras coletas de solo após o primeiro corte (Tabelas 24, 25, 26 e 27), que revela não somente os efeitos da calagem, mas também os da adubação de plantio e confrontando-os com os limites de interpretação de solos do Boletim Técnico 100 (Raij et al., 1996), observa-se que os teores de $\mathrm{P}$ sempre estiveram classificados como alto ou muito alto, os micronutrientes como altos, o enxofre que só foi analisado nas amostras de solo pós-incubação, neste momento também revelaram limites altos. Para o potássio apesar dos teores encontrados serem considerados médios, não devemos esquecer que este elemento é um dos mais extraído pelas forrageiras e que sempre as análises foram realizadas após o corte das mesmas, ou seja, durante o período inicial de crescimento, logo que se realizou a adubação potássica, os teores de $\mathrm{K}$ no solo possivelmente encontravam-se nas faixas limites de médios a altos.

Para os demais cortes (Tabelas 28 a 35), os micronutrientes sempre estiveram em limites altos com exceção de algumas oportunidades para o solol onde os teores de Mn e B passaram a revelar valores médios, para o $\mathrm{P}$ este também apresentou limites altos com exceção de algumas oportunidades para o solo2 onde possui teores médios, porém bem próximos ao limite para serem classificados como altos. O potássio foi o único elemento que se mostrou com teores baixos em algumas oportunidades, porém como será apresentado na discussão sobre os teores de minerais nas folhas, o teor de $\mathrm{K}$ nestas sempre estiveram entre 15 e $30 \mathrm{~g} \mathrm{~kg}^{-1}$, valores estes considerados normais para capins como Colonião ou Napier (Boletim Técnico 100), confirmando a hipótese de que possivelmente durante grande parte do crescimento os teores de $\mathrm{K}$ no solo estavam adequados à nutrição das forrageiras cultivadas.

Por outro lado durante o experimento foi verificado a totalidade de variação dos limites (muito baixo a muito alto) para a acidez e a saturação por bases, e ainda (baixo a alto) para os teores de cálcio e magnésio. Com estes resultados, verifica-se que se conseguiu manter durante todo o período experimental a grande variação nas 
. características químicas do solo justamente para os parâmetros que foram os alvos do estudo.

Para ter-se uma idéia de como se comportaram alguns parâmetros dos solos, ao logo de todo período experimental, foram traçados gráficos que mostram a evolução de algumas características diretamente envolvidas com os tratamentos, onde cada curva representou a evolução de um tratamento (média das quatro espécies cultivadas) para cada tipo de solo.

Deste modo, as Figuras $\mathbf{3 5}$ e $\mathbf{3 6}$ mostram a variação ocorrida nos valores de $\mathrm{pH}$ em $\mathrm{CaCl}_{2}$, as Figuras 37 e 38 mostram a variação na saturação por bases, as Figuras 39 e 40 mostram a variação nos teores de $\mathrm{Al}$, as Figuras 41 e 42 mostram a variação na saturação por $\mathrm{Al}$, as Figuras 43 e 44 mostram a variação nos teores de Ca, as Figuras 45 e 46 mostram a variação nos teores de Mg e finalmente as Figuras 47 e 48 mostram a variação ocorrida na relação Ca:Mg para ambos os solos.

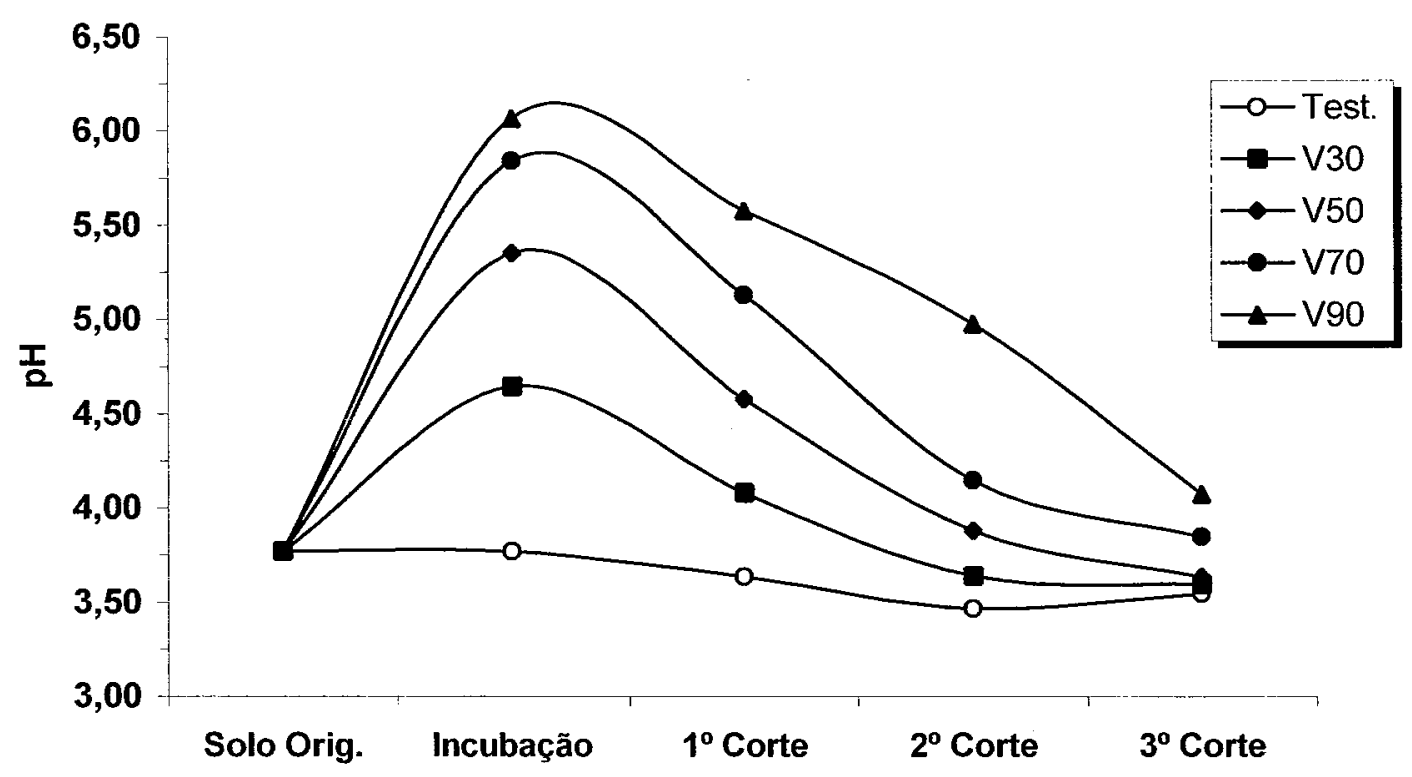

Figura 35- Variação do pH por tratamento (média das 4 espécies) ao longo do experimento para o solo 1. 


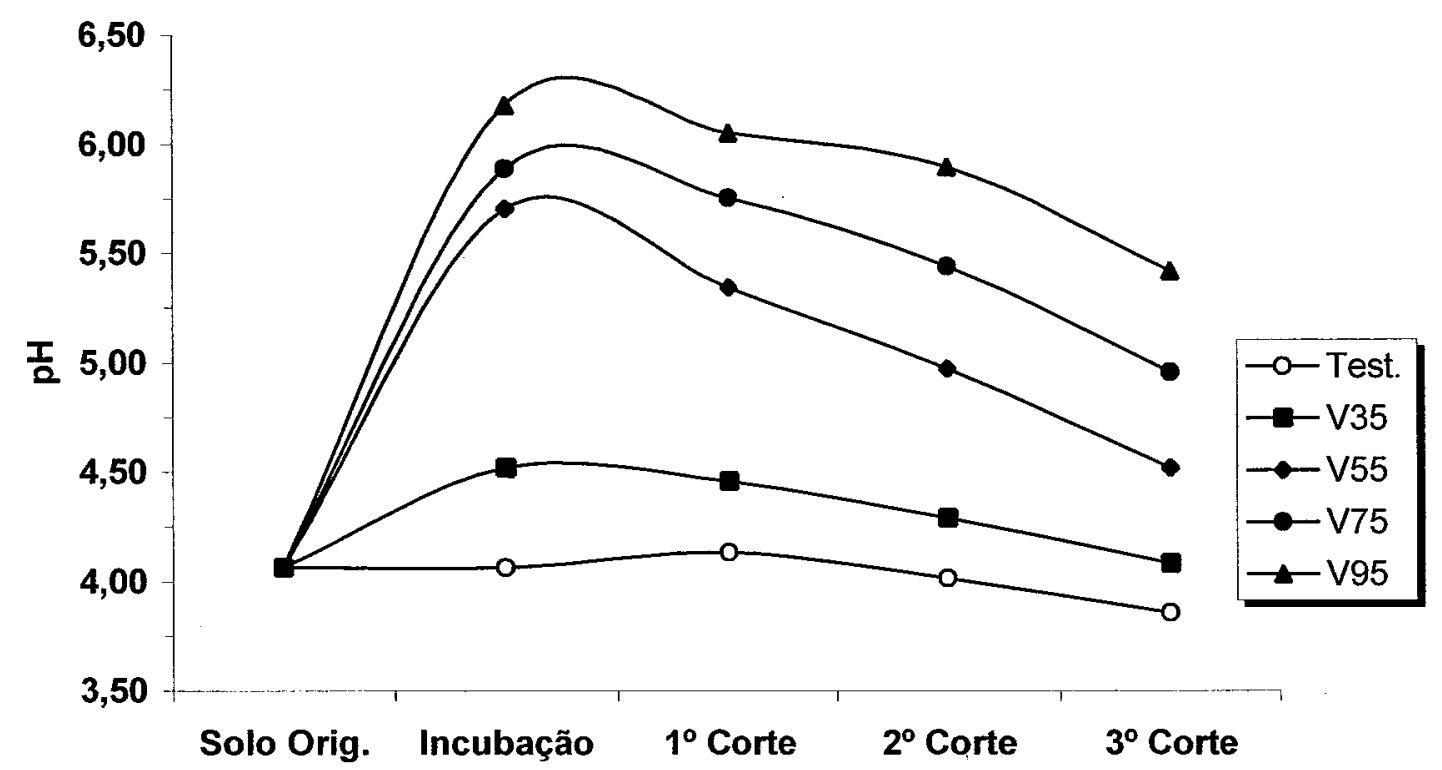

Figura 36- Variação do $\mathrm{pH}$ por tratamento (média das 4 espécies) ao longo do experimento para o solo 2.

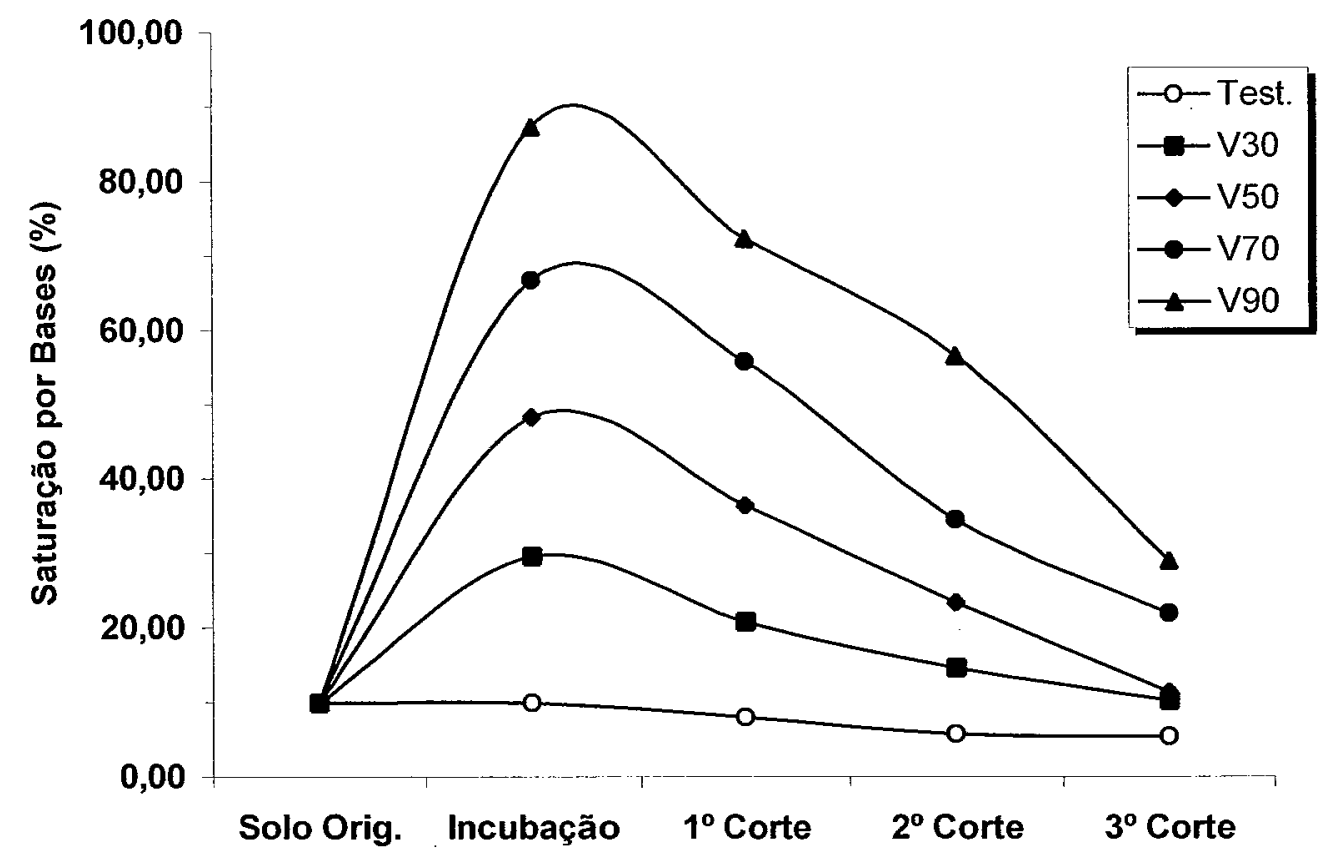

Figura 37- Variação da saturação por bases por tratamento (média das 4 espécies) ao longo do experimento para o solo 1. 


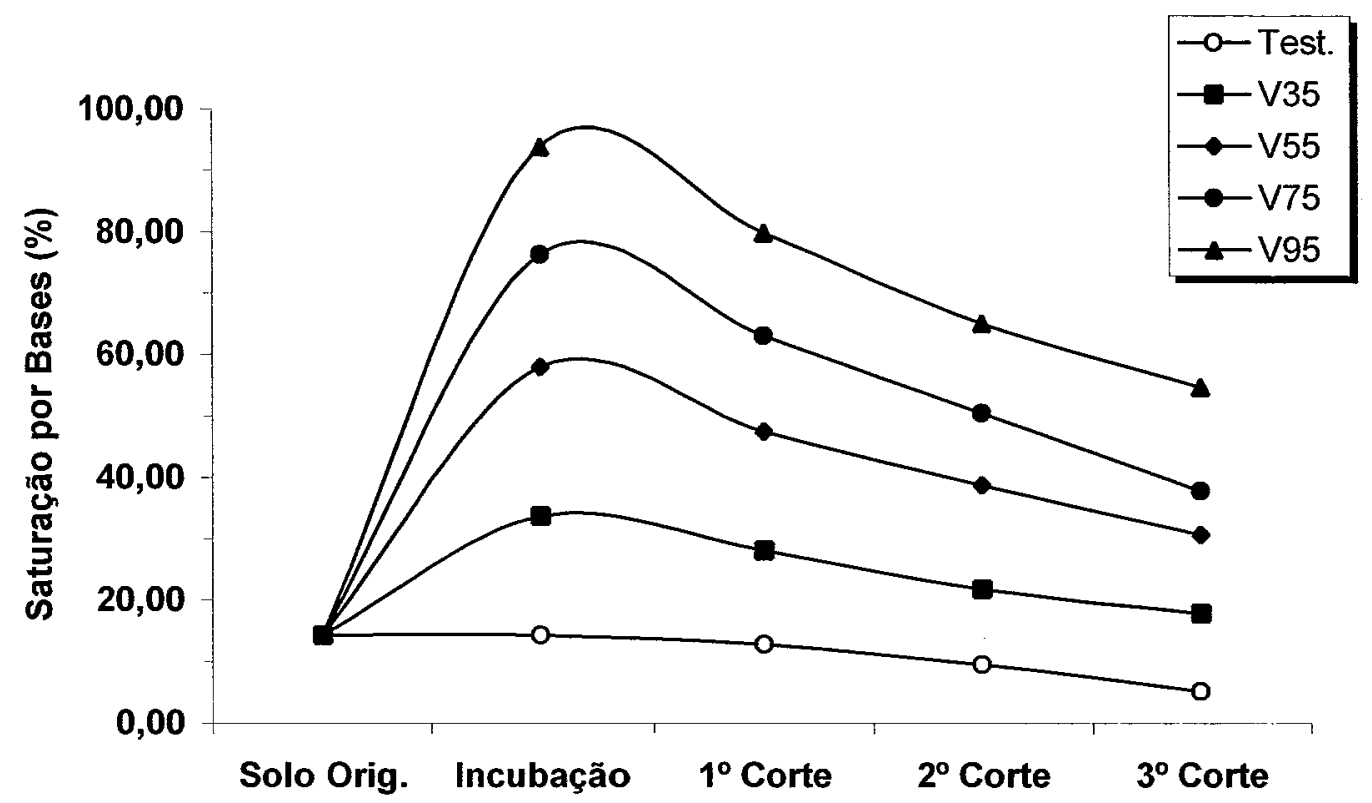

Figura 38- Variação da saturação por bases por tratamento (média das 4 espécies) ao longo do experimento para o solo 2 .

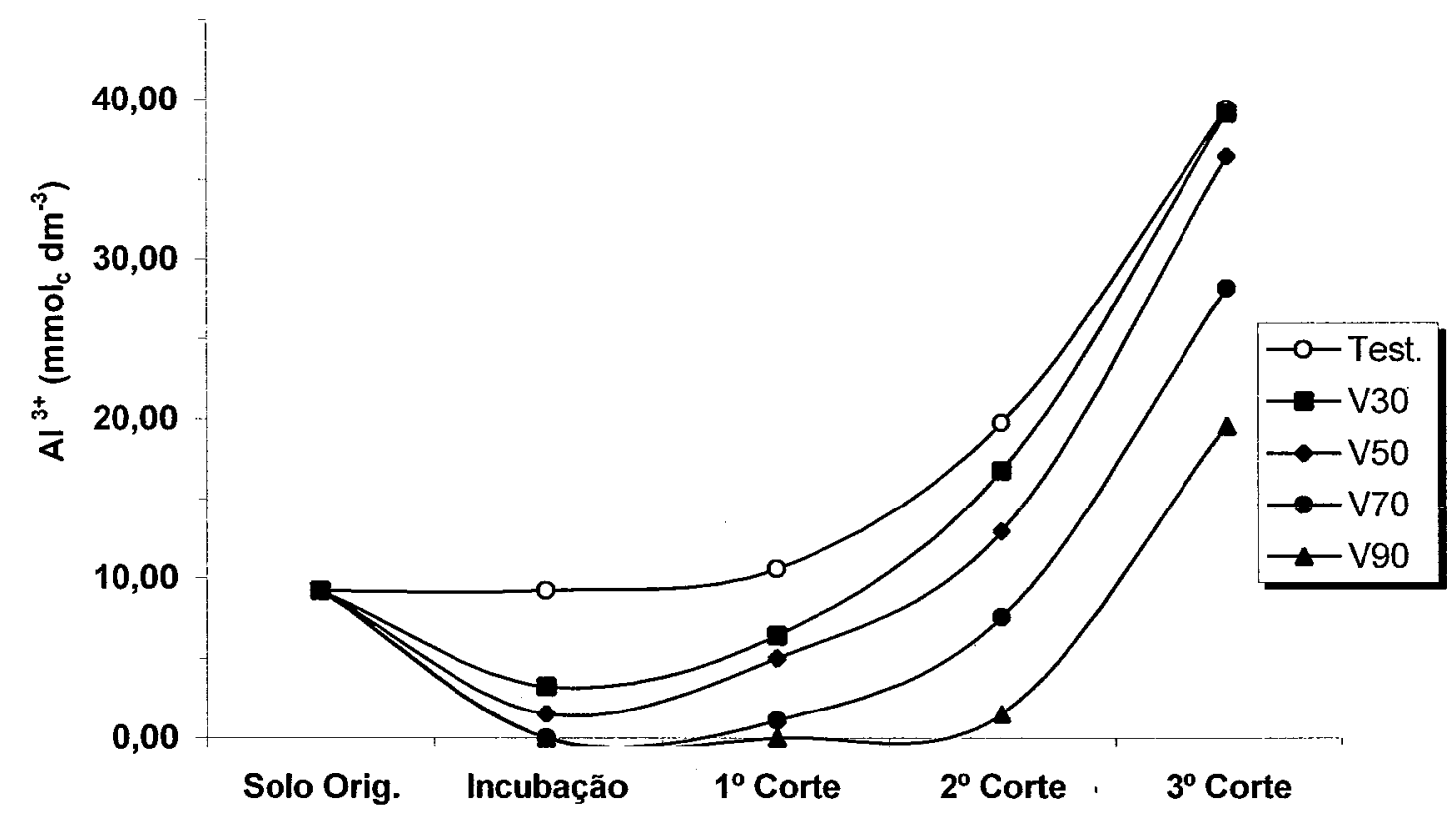

Figura 39- Variação do $\mathrm{Al}^{3+}$ por tratamento (média das 4 espécies) ao longo do experimento para o solo 1. 


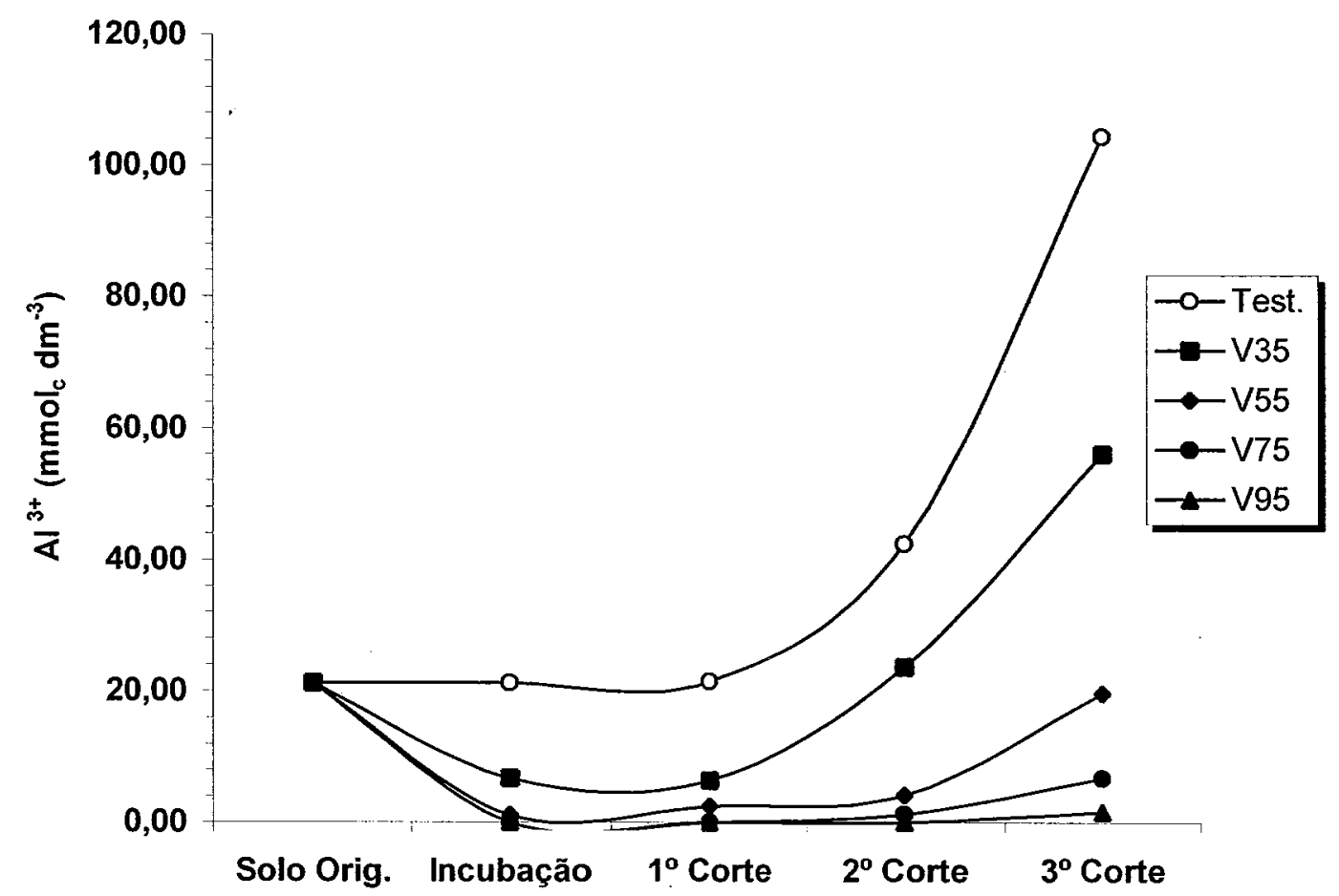

Figura 40- Variação do $\mathrm{Al}^{3+}$ por tratamento (média das 4 espécies) ao longo do experimento para o solo 2.

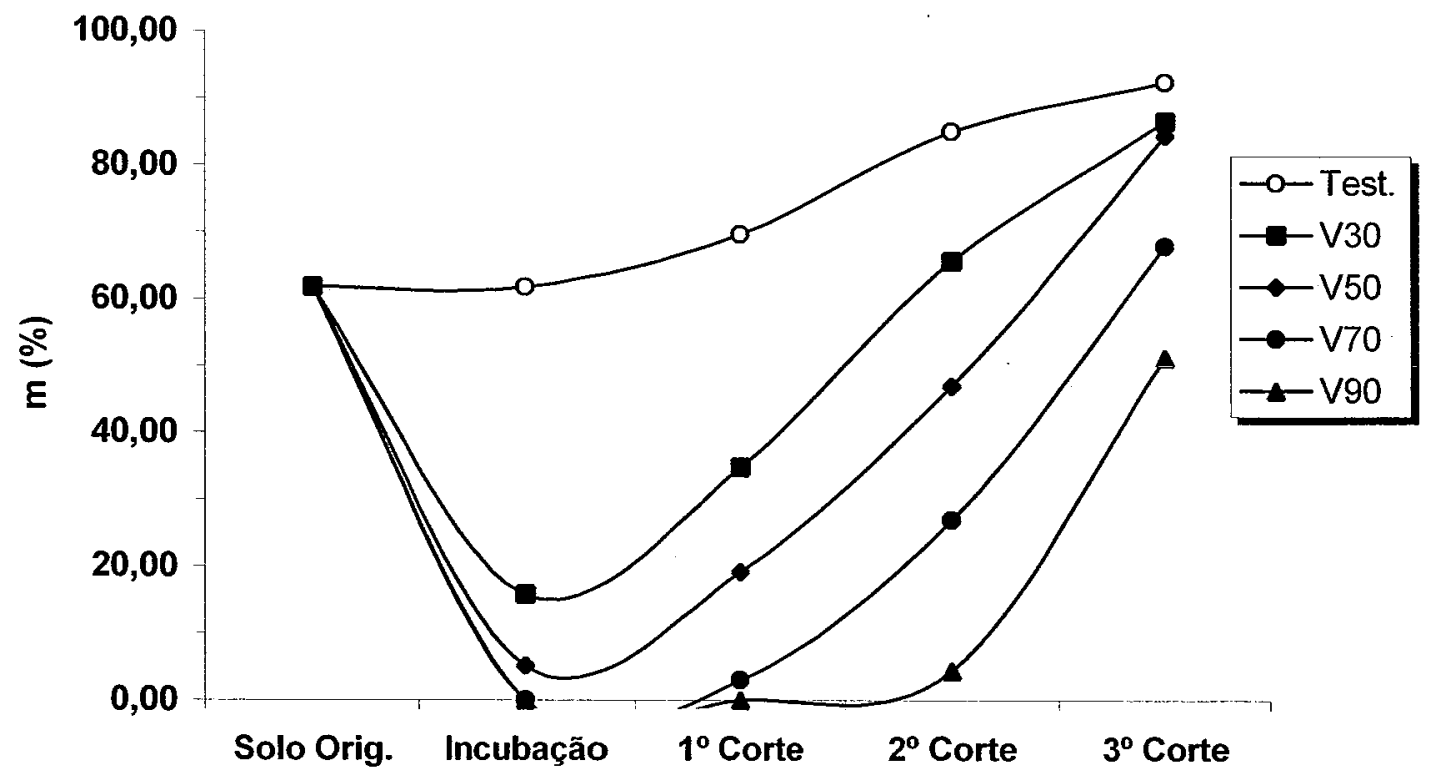

Figura 41- Variação da saturação de Al por tratamento (média das 4 espécies) ao longo do experimento para o solo 1. 


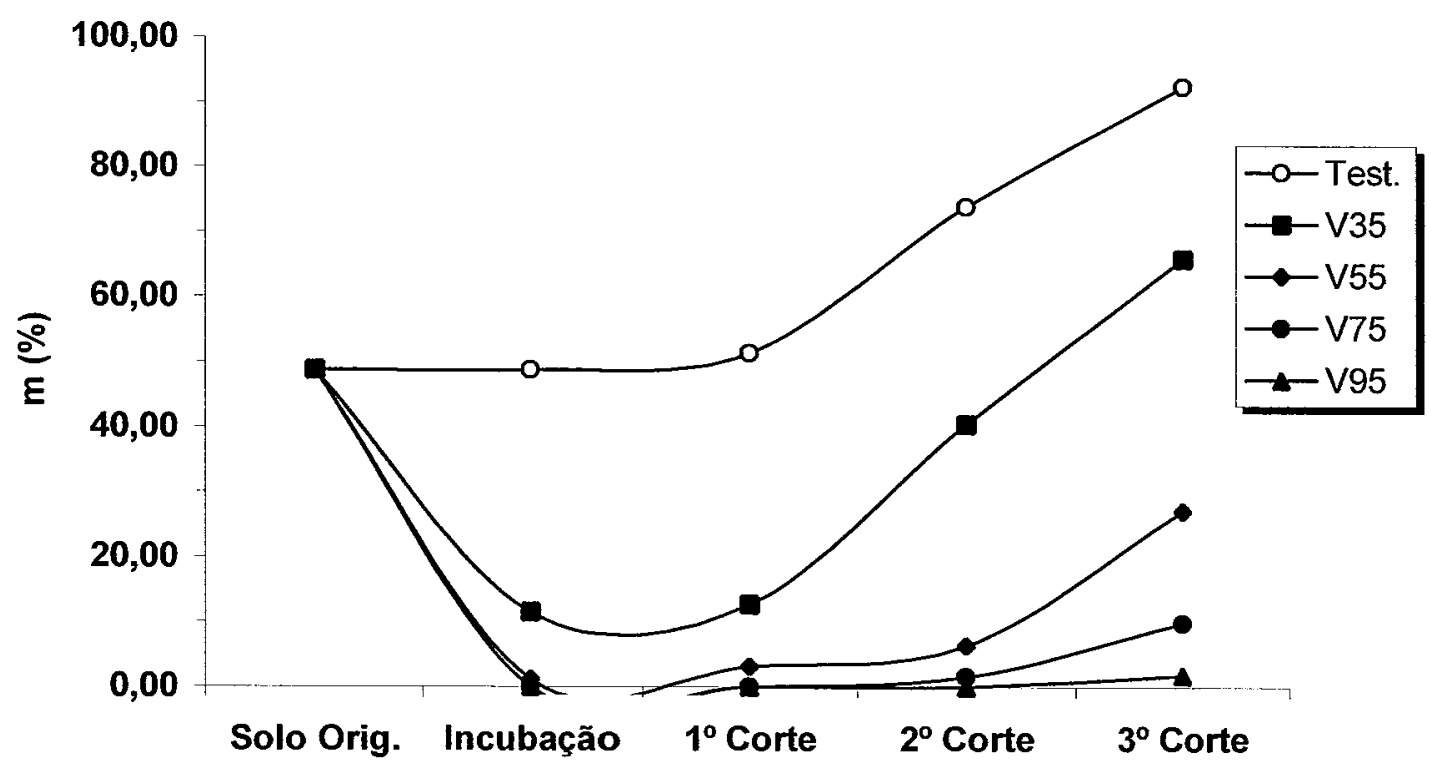

Figura 42- Variação da saturação de Al por tratamento (média das 4 espécies) ao longo do experimento para o solo 2 .

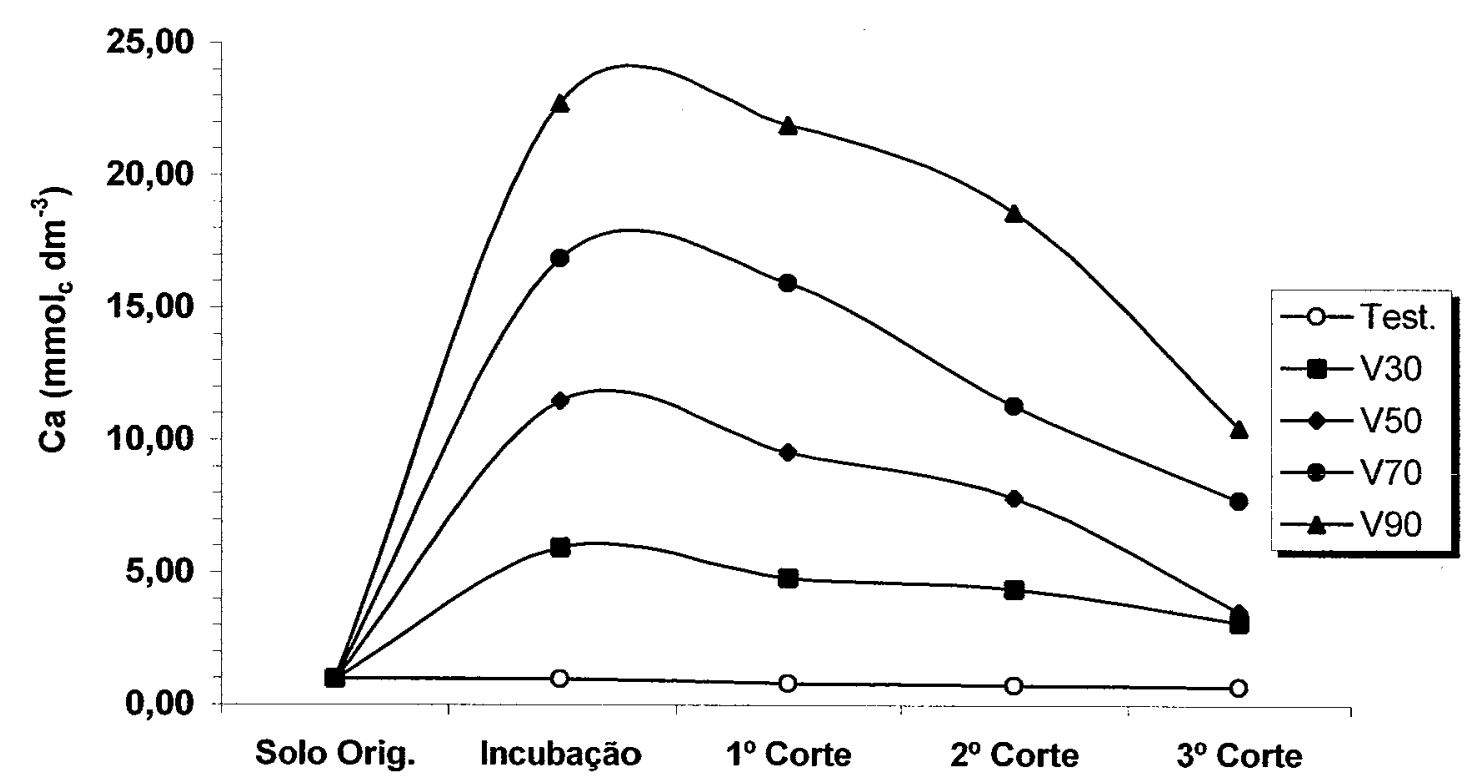

Figura 43- Variação do Ca por tratamento (média das 4 espécies) ao longo do experimento para o solo 1. 


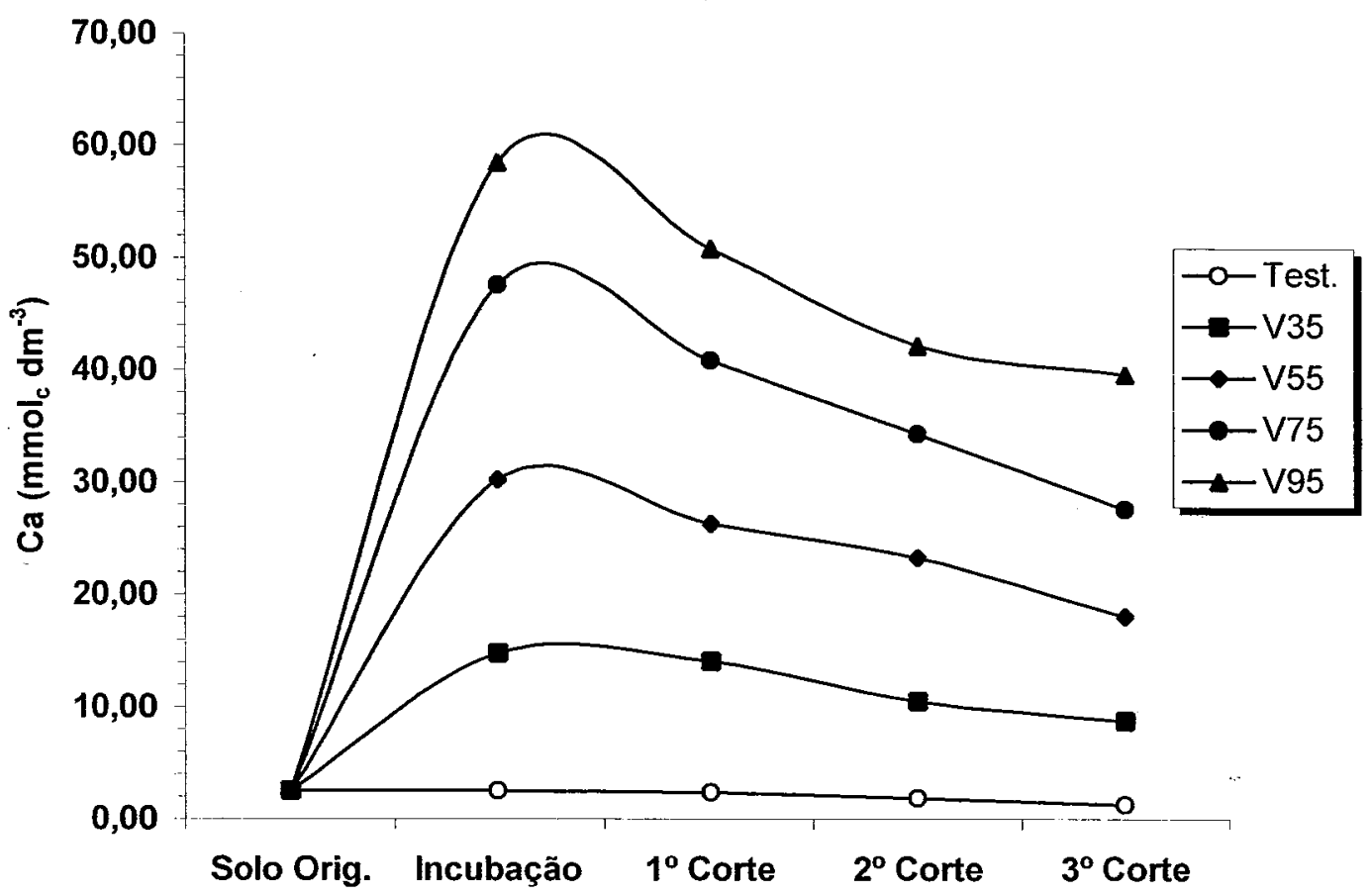

Figura 44- Variação do Ca por tratamento (média das 4 espécies) ao longo do experimento para o solo 2.

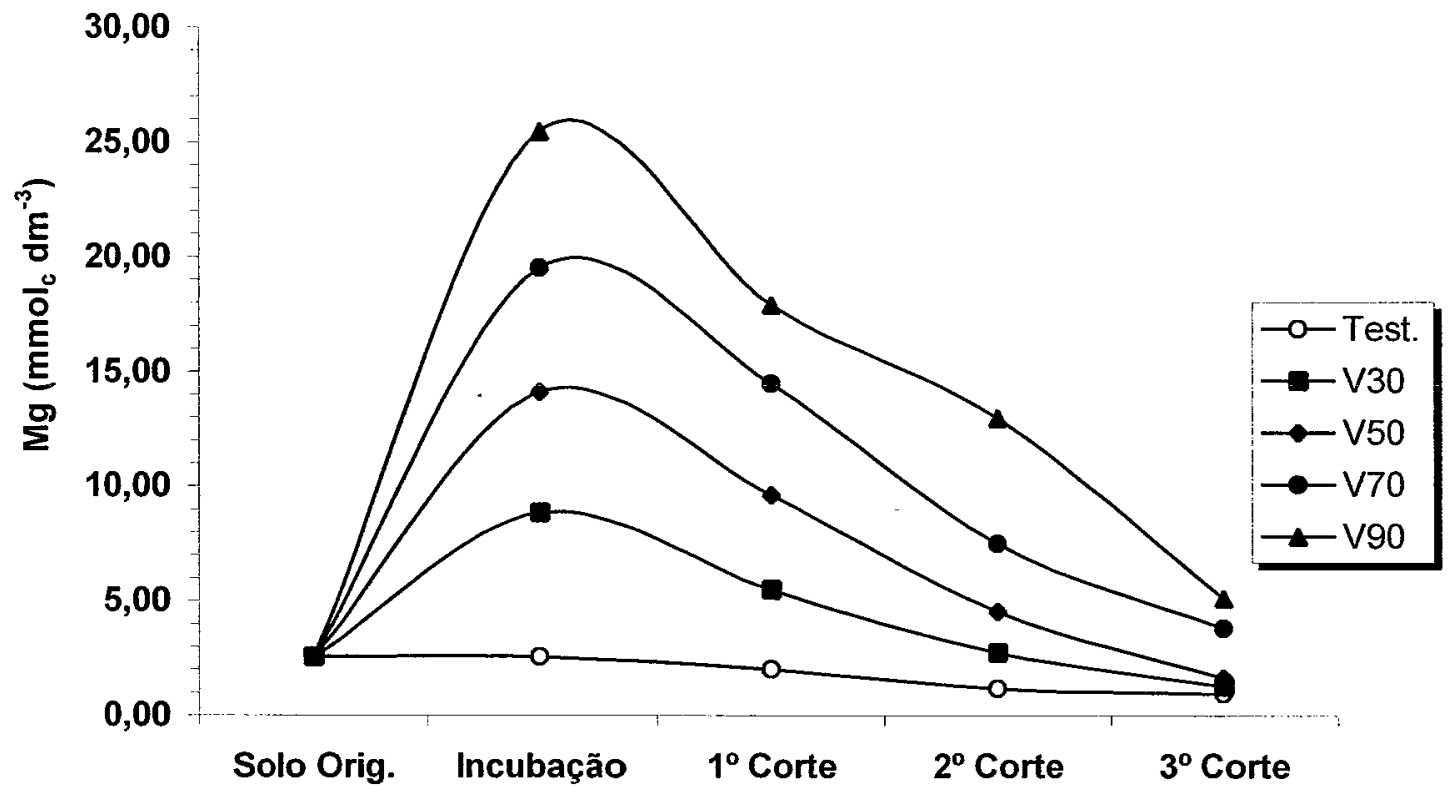

Figura 45- Variação do Mg por tratamento (média das 4 espécies) ao longo do experimento para o solo 1. 


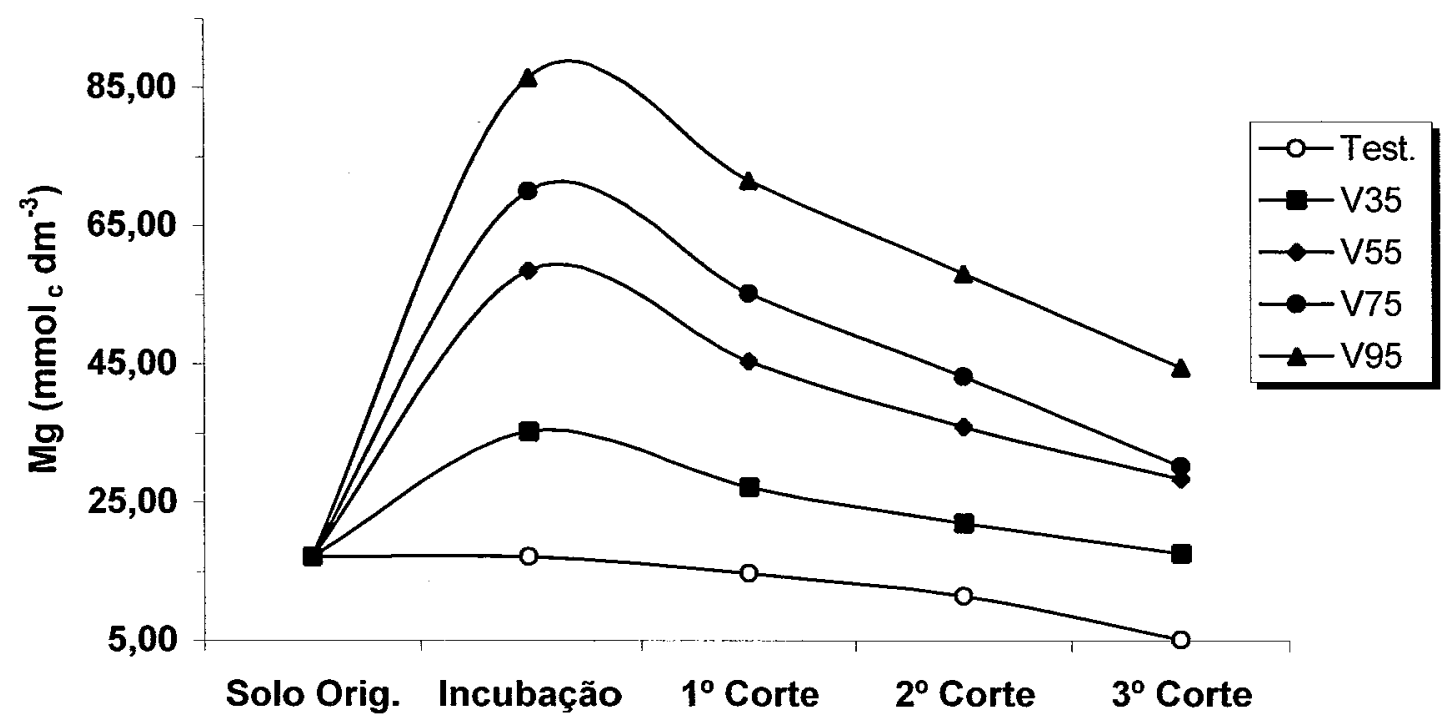

Figura 46- Variação do Mg por tratamento (média das 4 espécies) ao longo do experimento para o solo 2.

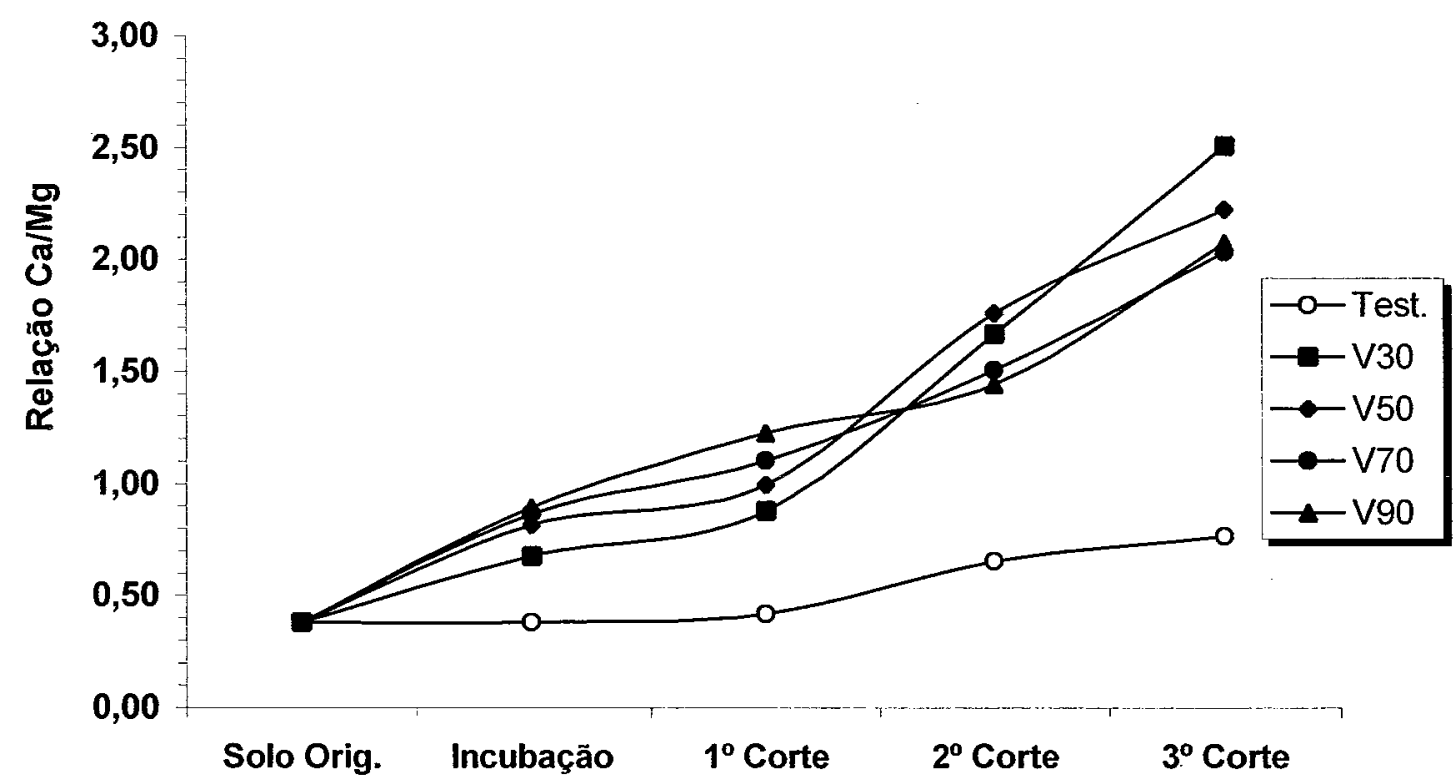

Figura 47- Variação da relação $\mathrm{Ca} / \mathrm{Mg}$ por tratamento (média das 4 espécies) ao longo do experimento para o solo 1. 


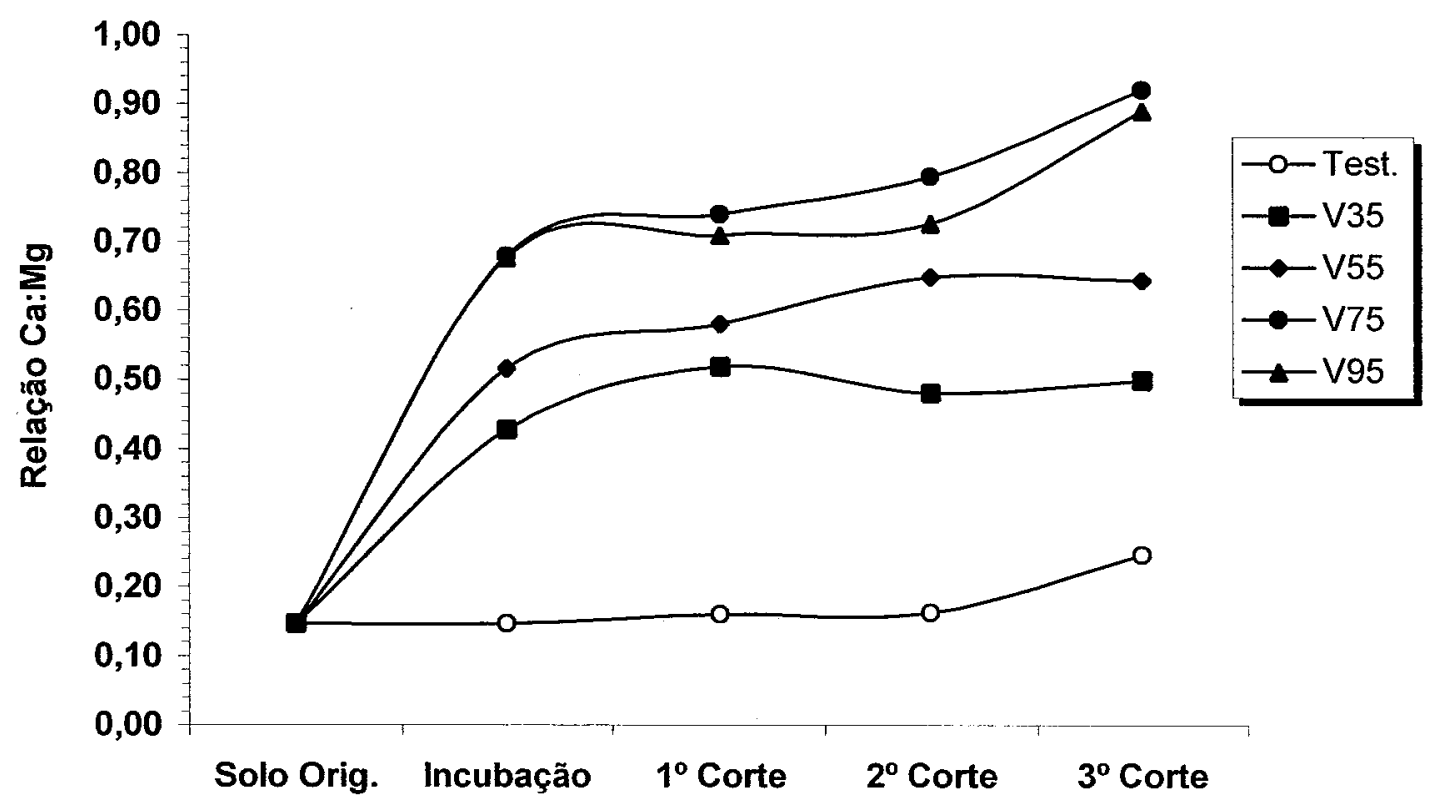

Figura 48- Variação da relação Ca/Mg por tratamento (média das 4 espécies) ao longo do experimento para o solo 2.

Como pode ser observado pelos gráficos acima traçados, houve uma elevada acidificação nos solos ao longo da fase experimental, paralelamente a esta redução de $\mathrm{pH}$, foram verificados aumentos nos teores e saturação de alumínio, associadas a reduções nos teores de Ca e Mg e ainda nas saturações por bases. Resultados estes que estão de acordo com os encontrados por Abruña (1958 e 1964), Vicente-Chandler et al.(1959a, 1959b e 1959c), Premazzi (1991), e que são justificados pela ação acidificante das elevadas aplicações nitrogenadas, aliado a remoção das bases Ca e Mg do sistema, já que as mesmas foram extraídas pelas forrageiras ao longo dos cortes realizados.

Outro aspecto importante que deixa bem evidente as diferenças entre os solos avaliados e a diferença em poder tampão dos mesmos. Isto pode ser notado pela inelinação das curvas, pois para o solo1 as diferenças entre os tratamentos vão diminuído ao longo dos cortes, convergindo todos os tratamentos para patamares bem próximos ao final do terceiro corte, enquanto para o solo2, que possui maior CTC, portanto maior reserva absoluta de bases, as curvas dos tratamentos sequem mais paralelas entre si até o final do experimento. Com isto fica evidente que critérios 
relativos, como a saturação por bases, não são bons indicadores para se prever a estabilidade do sistema solo ao longo do tempo.

E finalmente, outro fenômeno importante que ocorreu ao longo dos cortes foi a mudança na relação $\mathrm{Ca}: \mathrm{Mg}$, apresentando um comportamento crescente ao longo dos cortes. Como será apresentado no momento da discussão dos teores de minerais nas folhas, foram verificados maiores teores de $\mathrm{Mg}$ em relação ao Ca no primeiro corte de todas as espécies cultivadas em ambos os solos, mostrando obviamente relações Ca:Mg menores que 1, mas que foram aumentado ao longo dos cortes, ou seja, a extração diferenciada entre $\mathrm{Ca}$ e $\mathrm{Mg}$ acabou por alterar a relação $\mathrm{Ca} / \mathrm{Mg}$ inicial do solo.

Tabela 22 - Análise de micronutrientes após o período de incubação definitiva

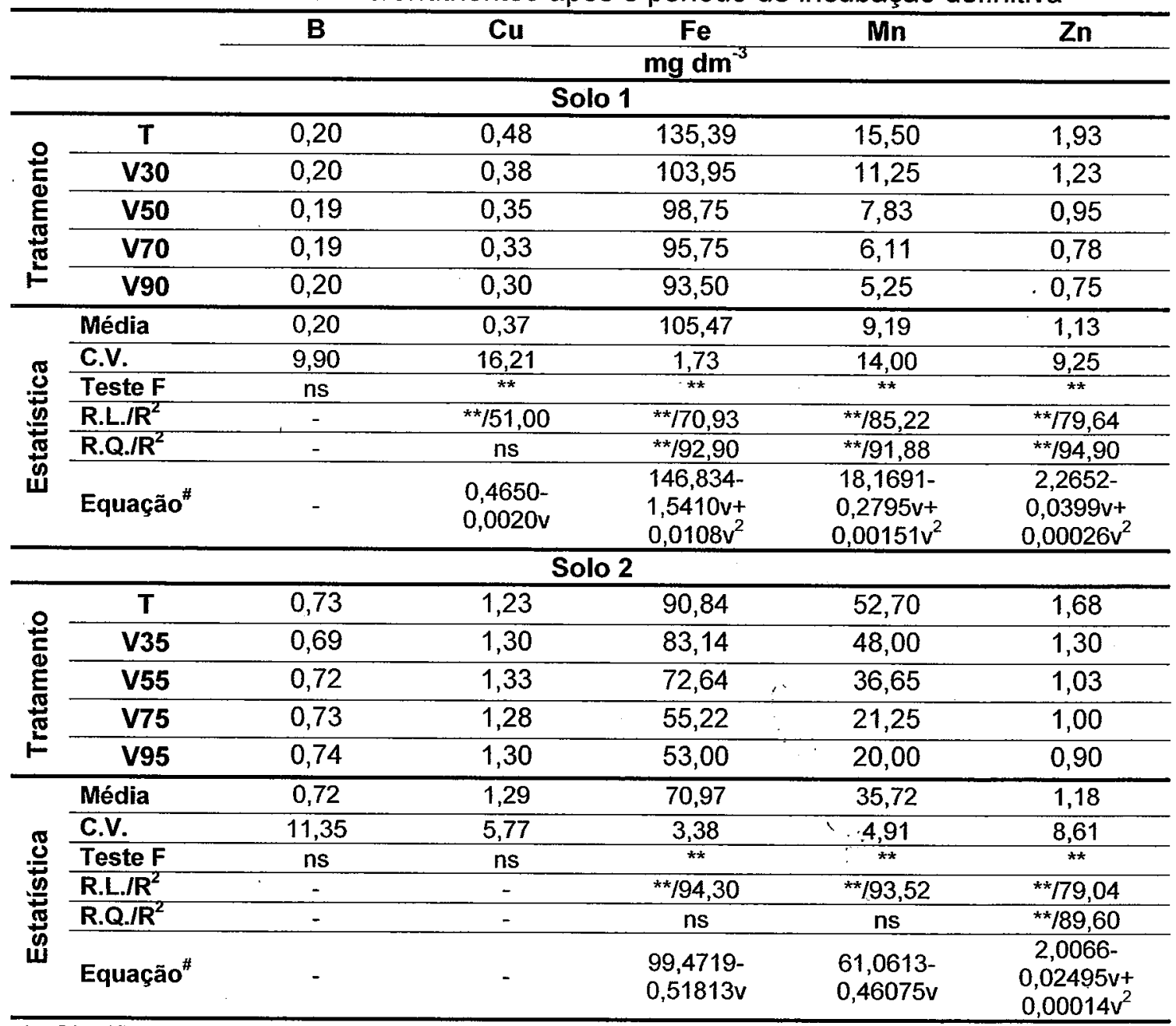

*- Significativo ao nivel de 5\%; **- Significativo ao nivel de 1\%; R.L-regressão linear; R.Qregressão quadrática. "- Refere-se a equação de maior grau que foi significativa. 


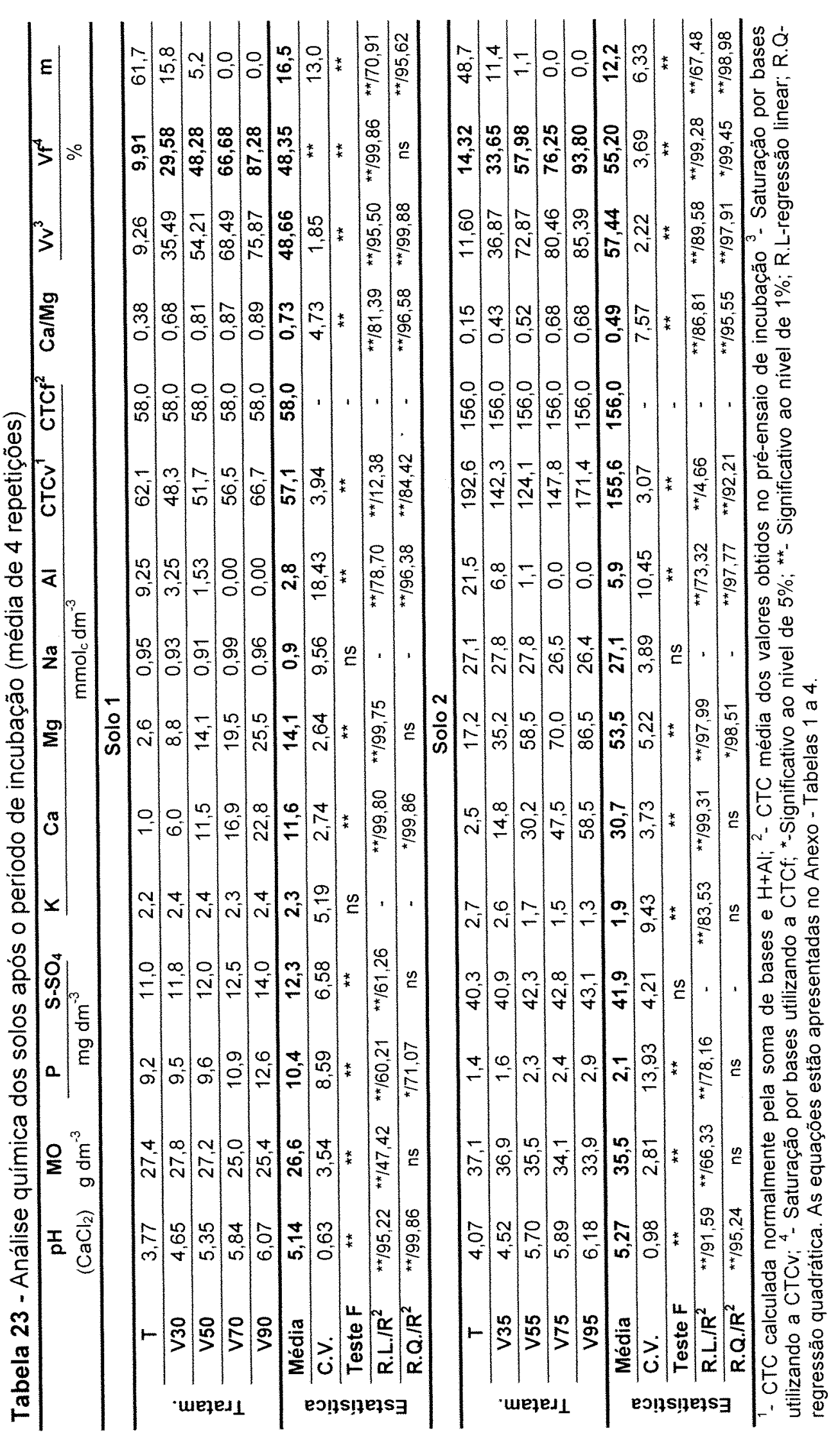




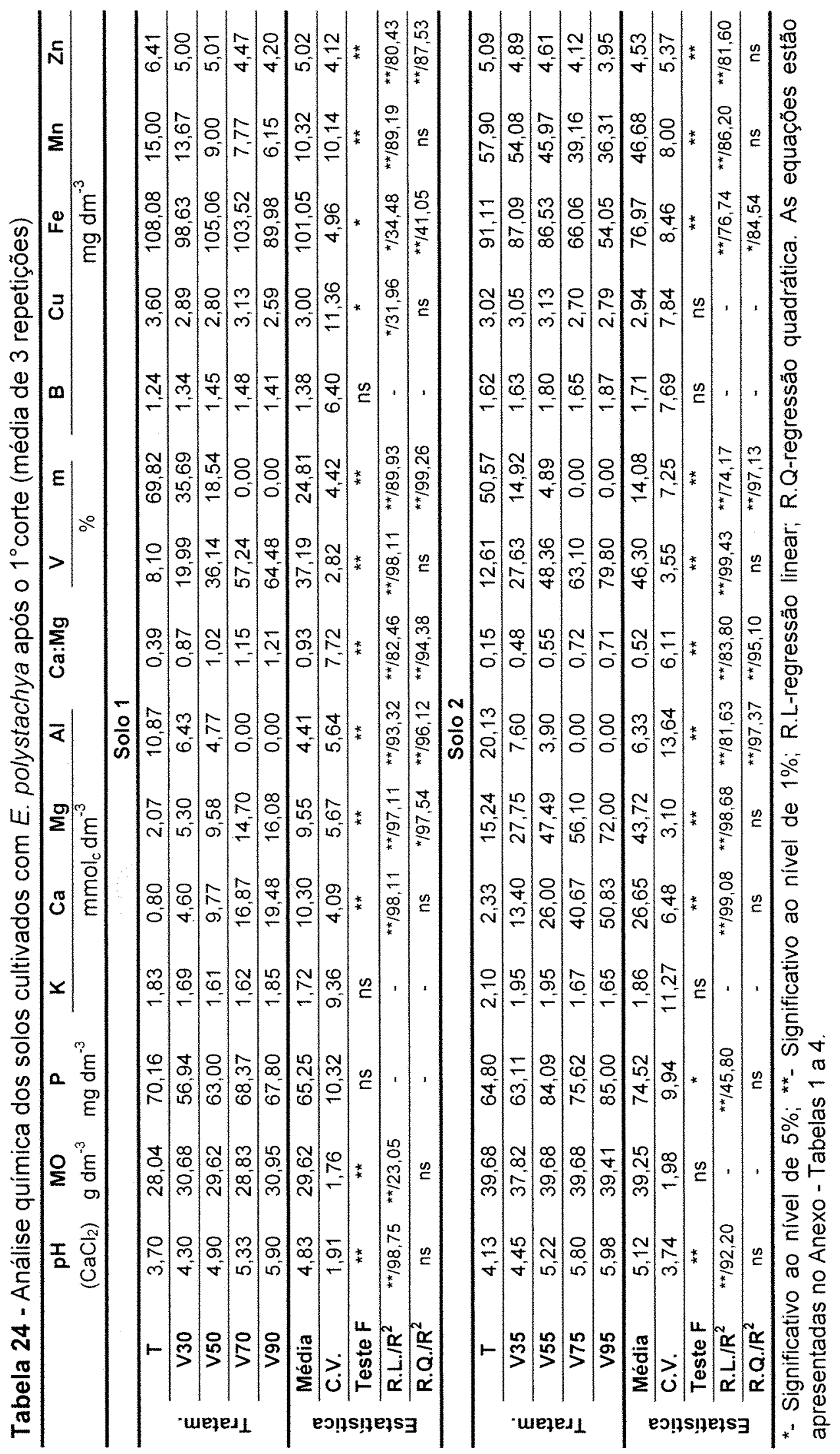




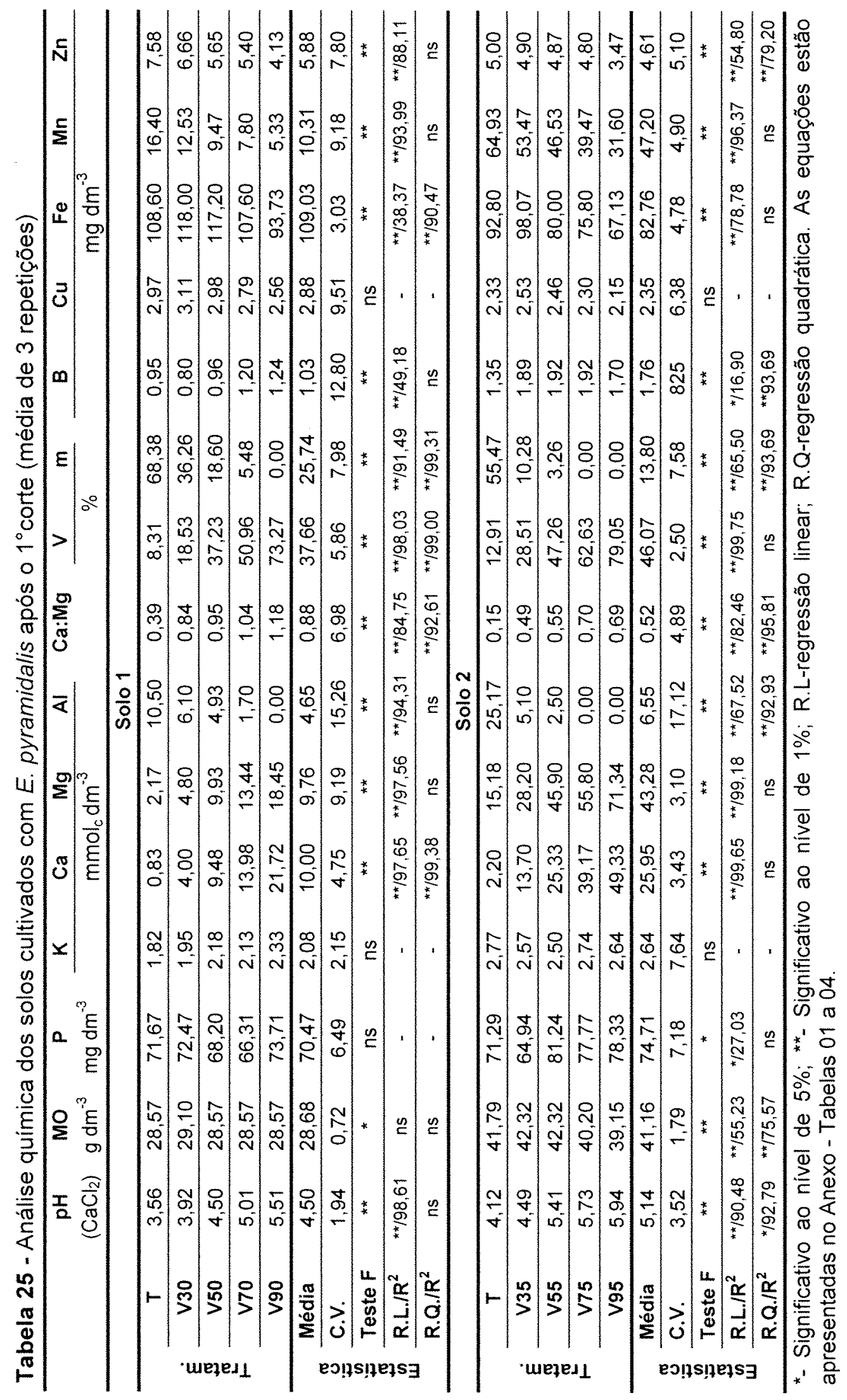




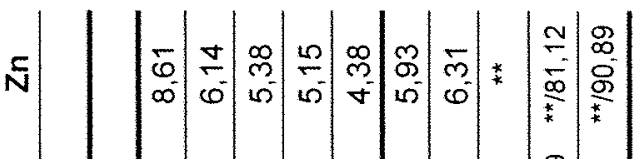

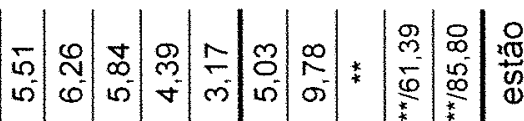

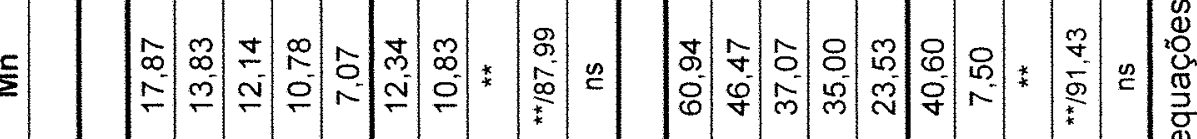

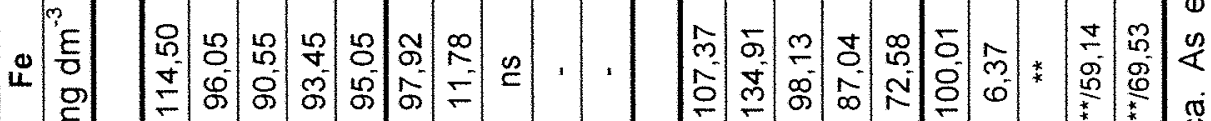

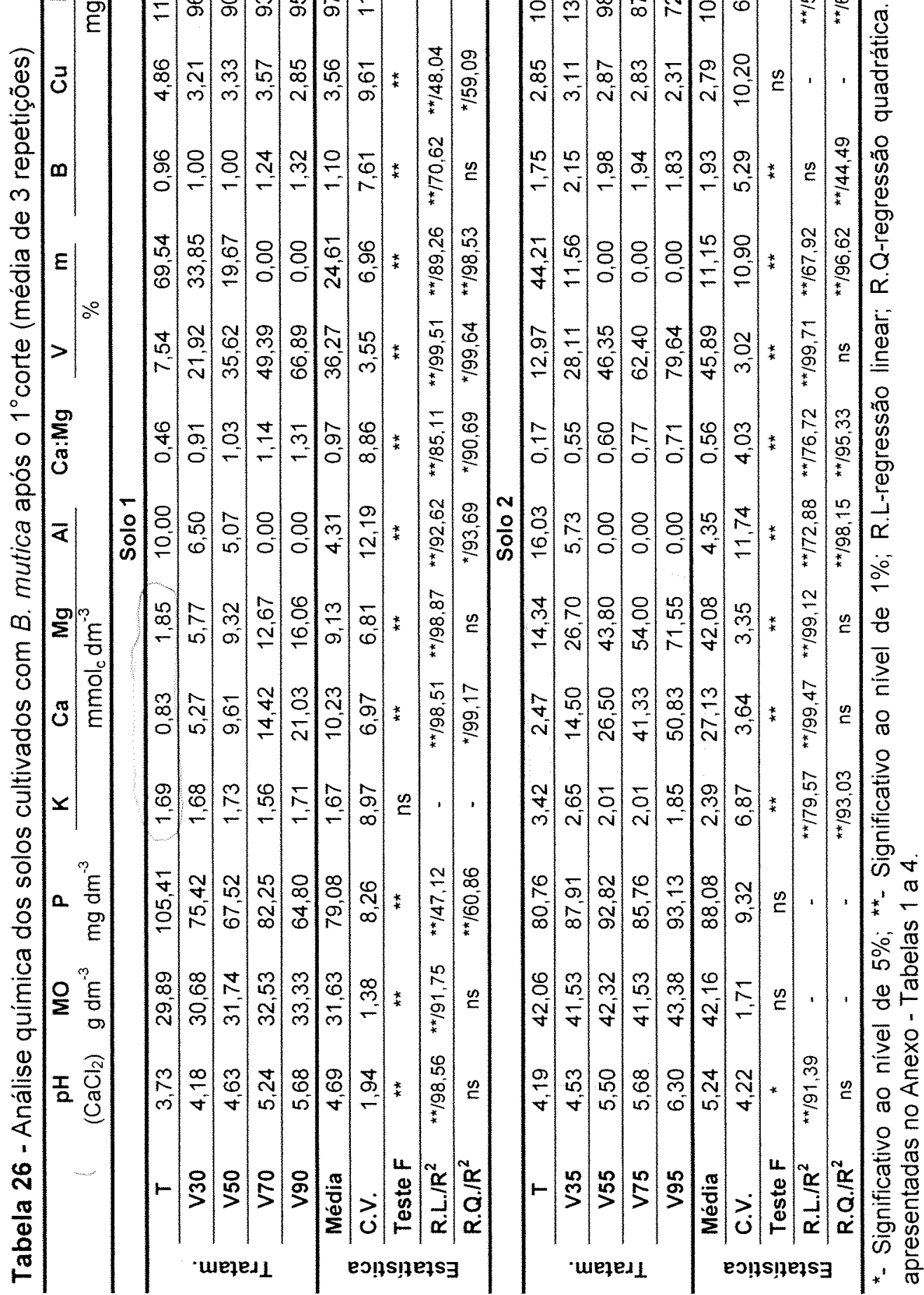




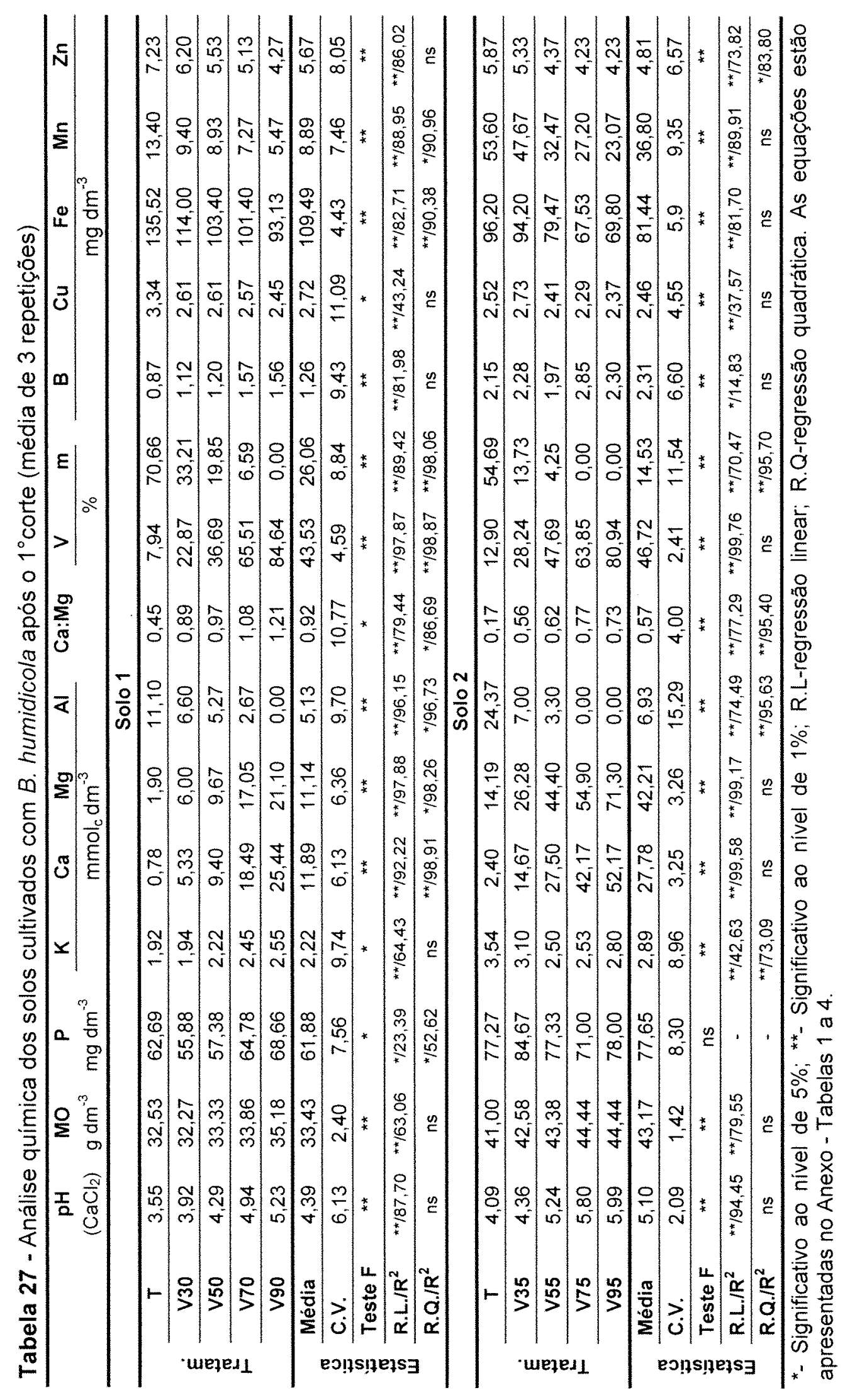




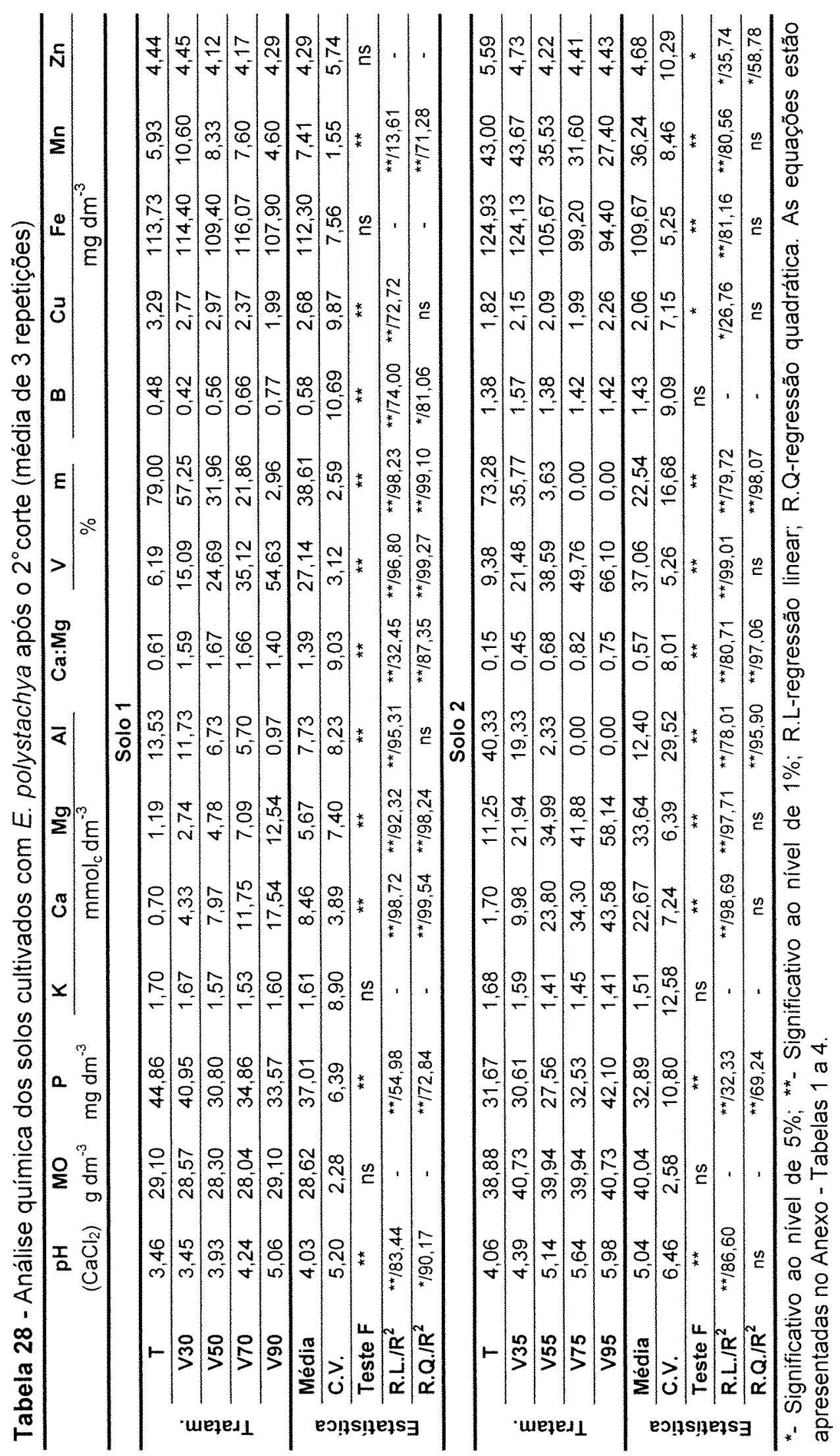




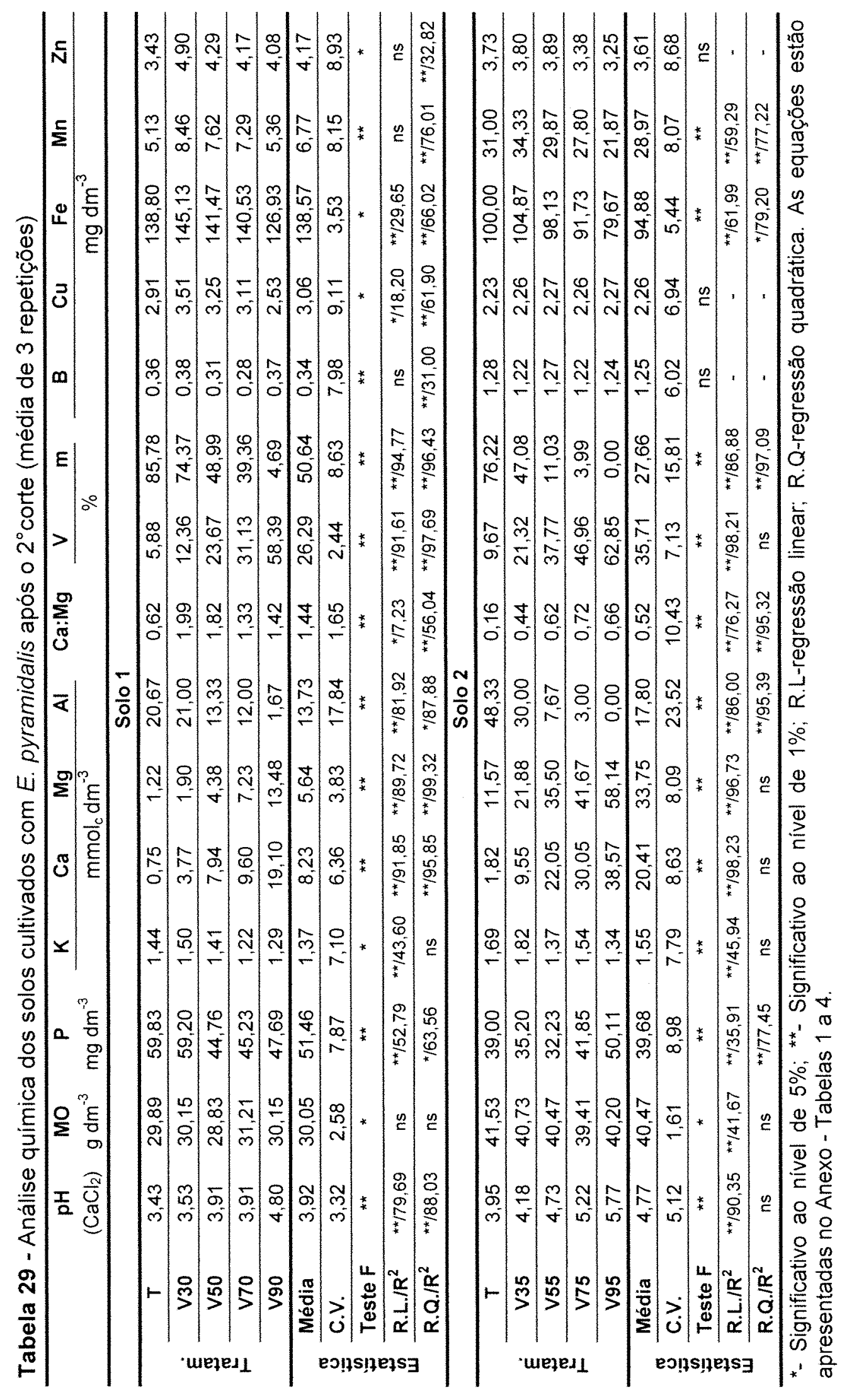




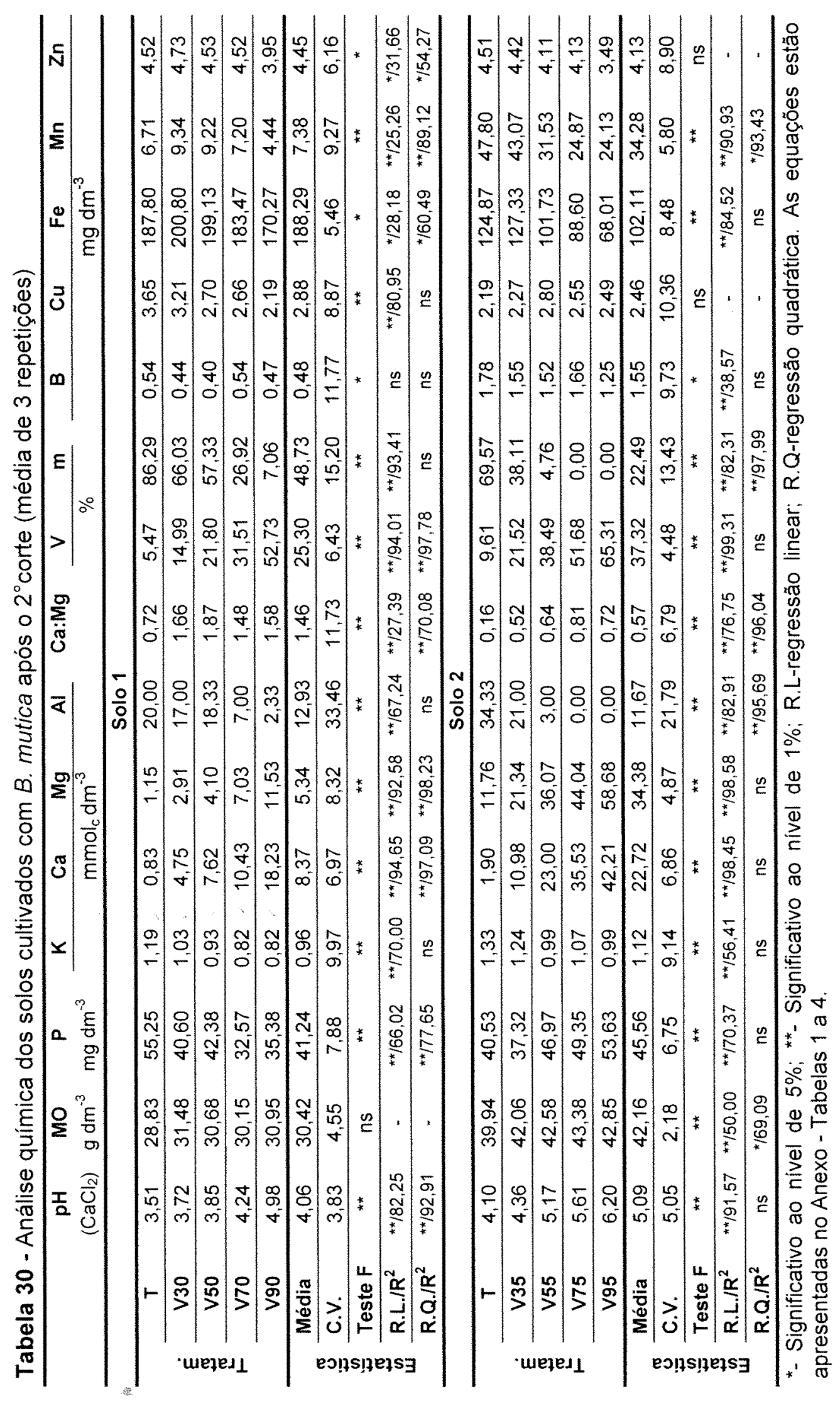




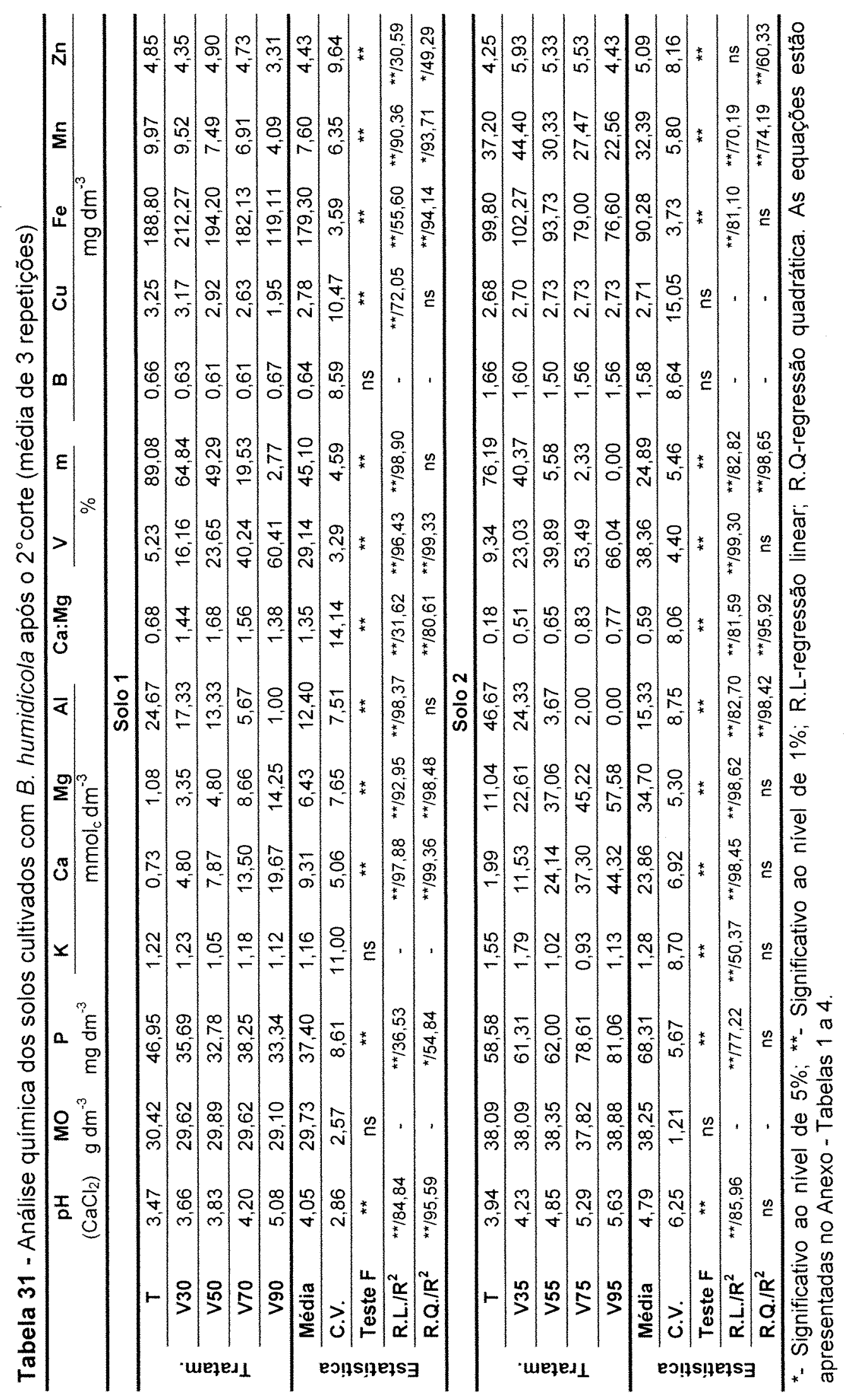




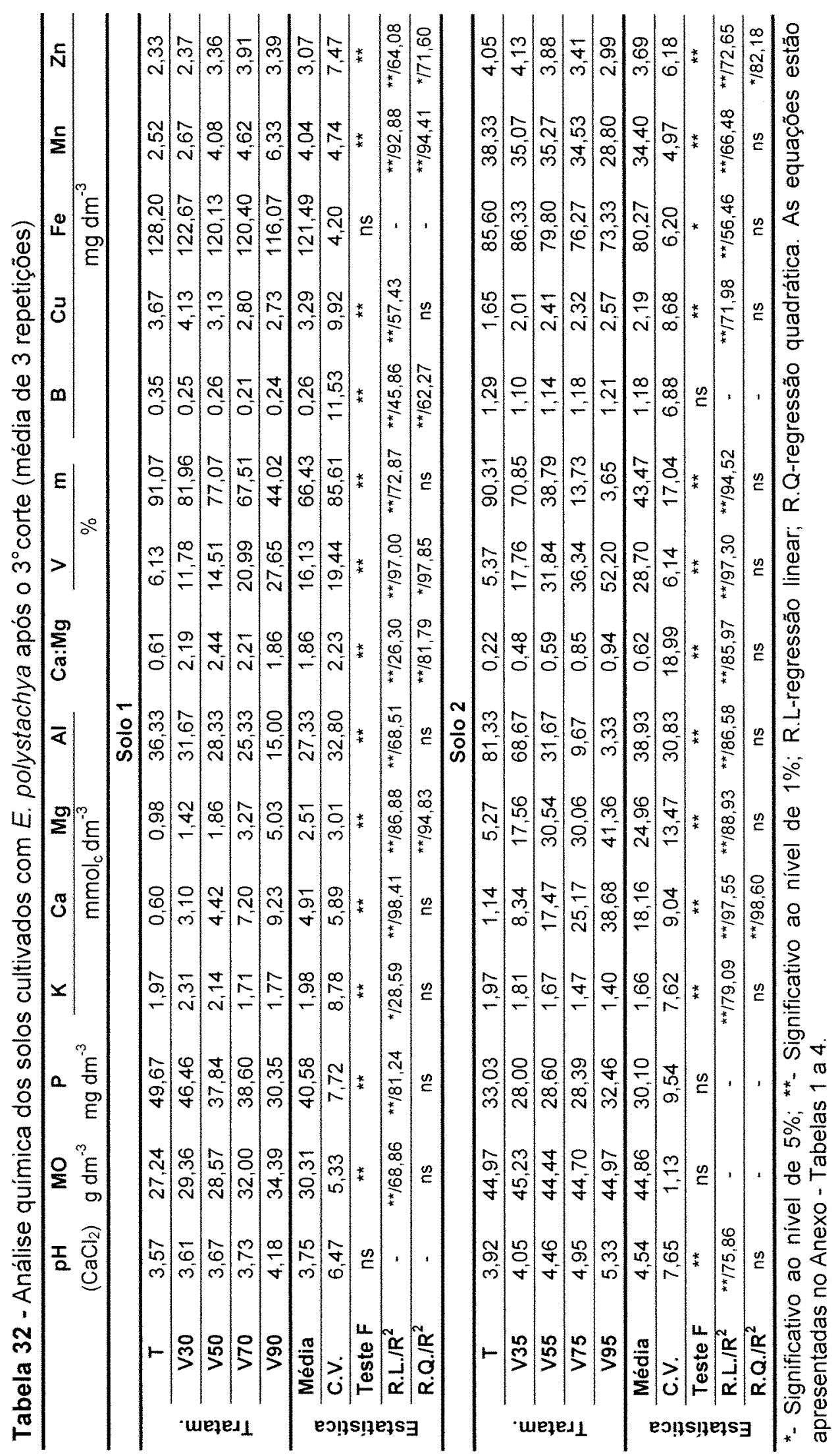




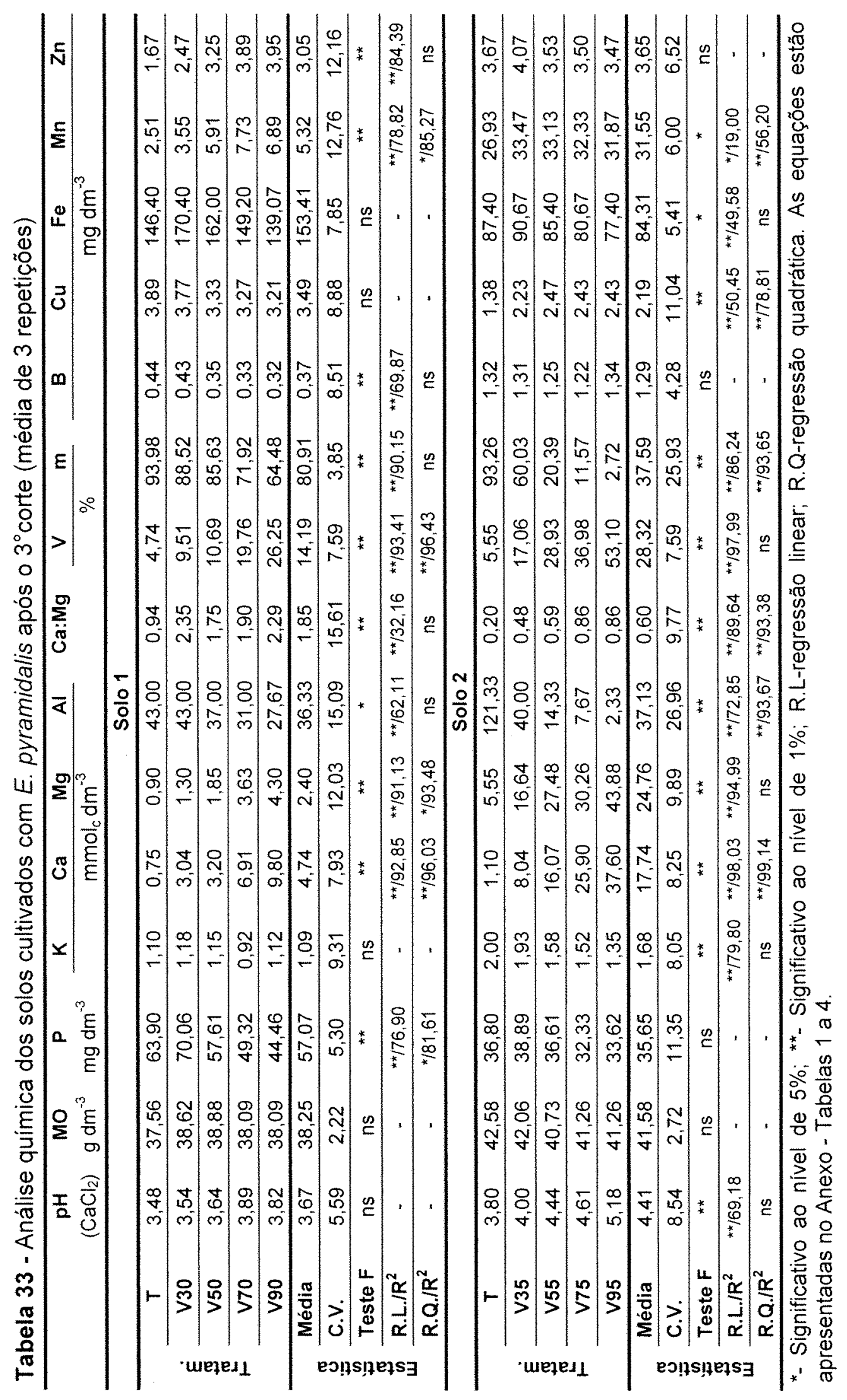




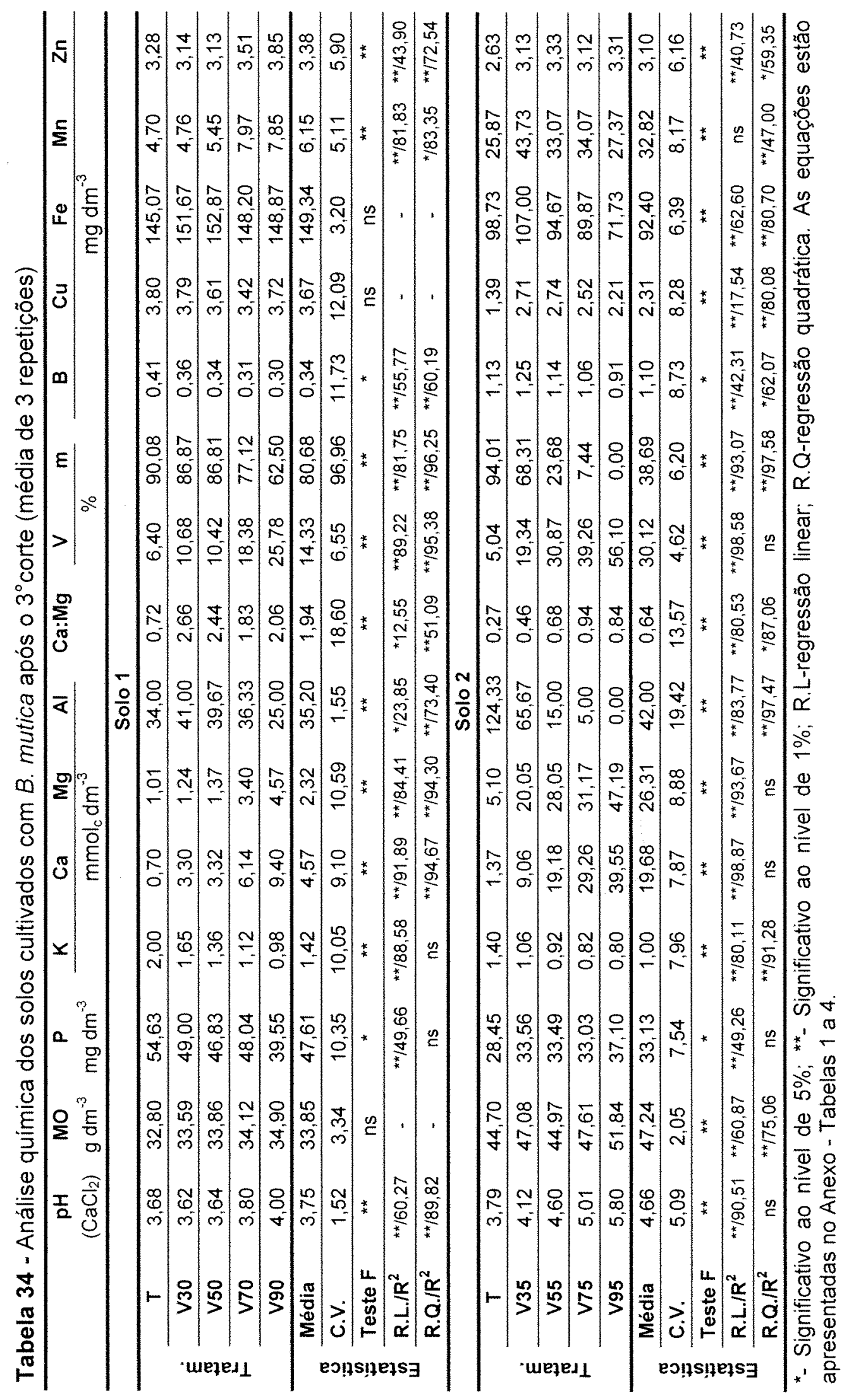




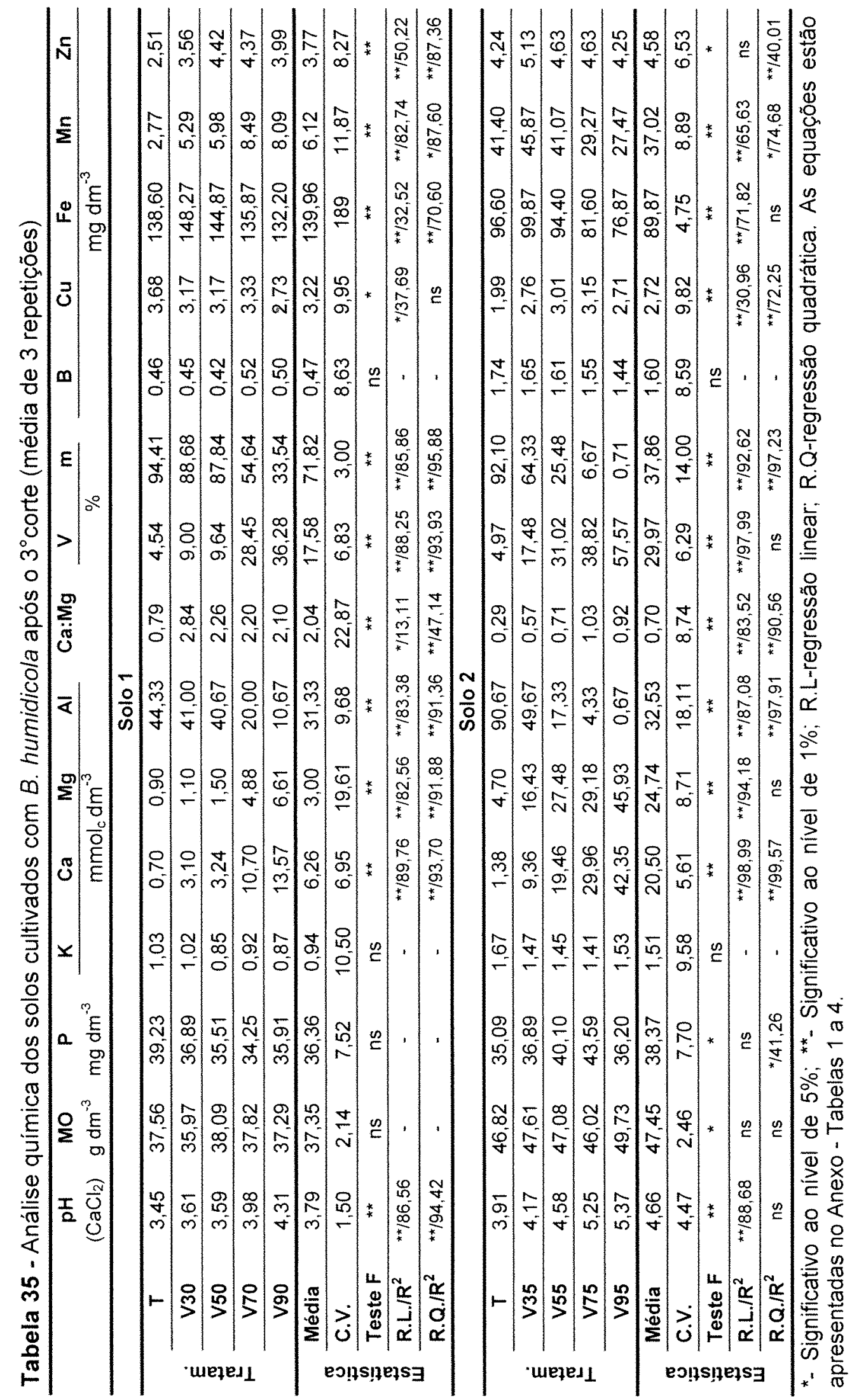




\subsection{PRDDUÇÃ̃ de TECIDD VEGETAL}

Os parâmetros obtidos diretamente, como: produção de matéria natural, produção de matéria seca, composição botânica, perfilhamento, área foliar, produção de raízes, assim como os indiretos: teores de matéria seca e relação folha:haste estão apresentados nas Tabelas 36 a 54. As Figuras 50 a 53; 56 a 59; 65 a 68 e 68 a 71 mostram as forrageiras no momento do $1^{\circ}$ e $3^{\circ}$ corte. Observou-se que todos os parâmetros relativos à produção, independentemente da espécie ou do solo cultivado, tiveram seus valores acrescidos em suas magnitudes ao longo dos 3 cortes realizados, o que mostra a não limitação, pelo menos em espaço físico, para o crescimento das forrageiras até um terceiro corte, quando cultivadas nestas condições. Devido a estes parâmetros terem tido um comportamento bem individualizado entre as espécies, irá se apresentar os resultados obtidos isoladamente para cada espécie em cada solo e ao final da descrição dos resultados da última espécie a discussão será finalizada, agrupando-se os resultado semelhante, e confrontando-os com a literatura. Os parâmetros, taxa de acúmulo diário total e taxa de acúmulo diário de folhas, também estão apresentados nas tabelas mencionadas acima, com o intuito de uma possível comparação apenas numérica entre as espécies e os solos, pois como é sabido, os mesmos têm delineamentos estatísticos independestes.

\subsubsection{E. POLYSTACHYA}

Esta espécie mostrou-se muito pouco responsiva à calagem, sendo que, das oito observações feitas referentes a MST, agrupando-se os dois tipos de solo, somente a MST produzida em todo experimento, cultivada no solo 2 foi significativamente afetada, revelando estatisticamente um modelo matemático linear crescente, porém os incrementos de produção foram pequenos em relação às doses crescentes de calcário, mostrando apenas $5,8 \%$ de aumento entre o máximo produzido no tratamento V75 e a testemunha (Figura 49). Ao realizar-se um teste de comparação de médias, verificou-se que a produção do tratamento testemunha não diferiu estatisticamente do tratamento que 
mais produziu. $E$ ainda ao verificarmos o parâmetro $M S T+R$, que engloba toda a produção de MS da parte aérea mais raízes o efeito significativo da calagem desaparece.

Por outro lado em 5 das 8 observações realizadas, foi verificado um efeito positivo da calagem na produção de MSF $\left(1^{\circ}\right.$ corte no solo1, $2^{\circ}$ corte no solo $2,3^{\circ}$ corte no solo2, Produção Total no solo1 e solo2), apresentando um padrão linear em 4 das 5 vezes que este efeito foi verificado. Porém mais uma vez, ao consideramos a produção total (soma dos 3 cortes), apesar deste padrão linear de resposta, o incremento em produção de folhas para o solo 1 foi de apenas $9,39 \%$ e para o solo 2 de 9,25\% respectivamente para os tratamentos $V 70$ e V75, quando comparados às testemunhas.

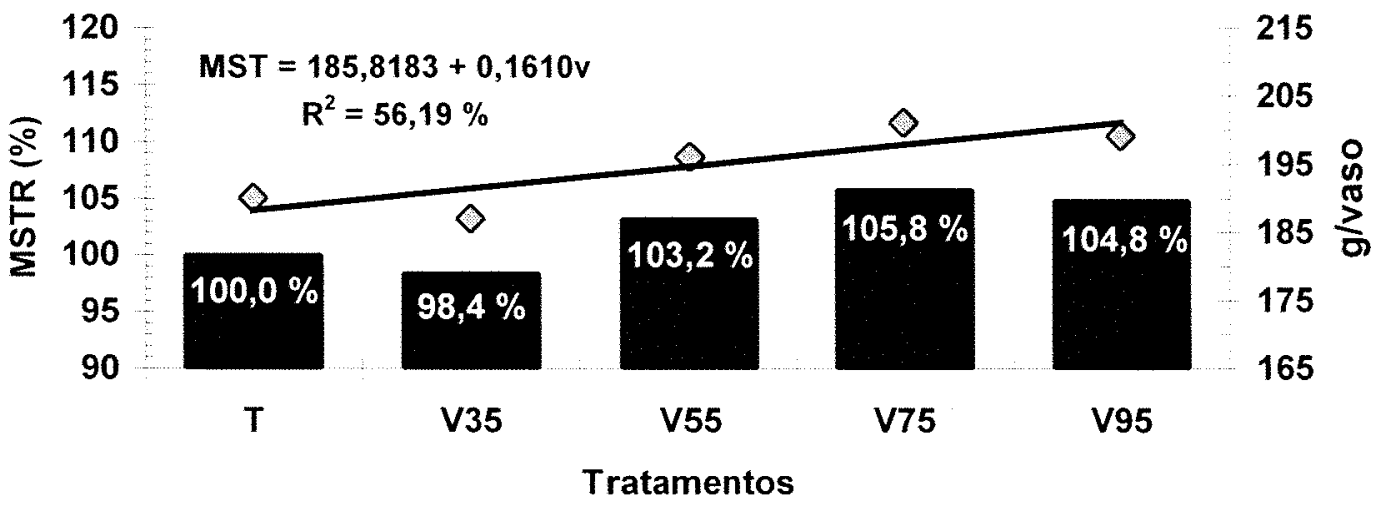

Figura 49- Produção de matéria seca total (parte aérea), somatório das médias dos 3 cortes, da E. polystachya cultivada no solo 2 .

Apesar deste comportamento na produção de folhas, em nenhuma ocasião foi verificado efeito significativo na relação folha:haste. E somente em uma ocasião este efeito na produção de folhas foi acompanhado de resposta na área foliar $\left(3^{\circ}\right.$ corte no solo 2), mostrando um crescimento linear com as doses de calcário, porém mostrando um modelo matemático que pouco explicou o fenômeno $\left(R^{2}=31,61 \%\right)$. O parâmetro número de perfilhos produzidos em ambos os solos também não foi afetado em nenhuma das observações. 


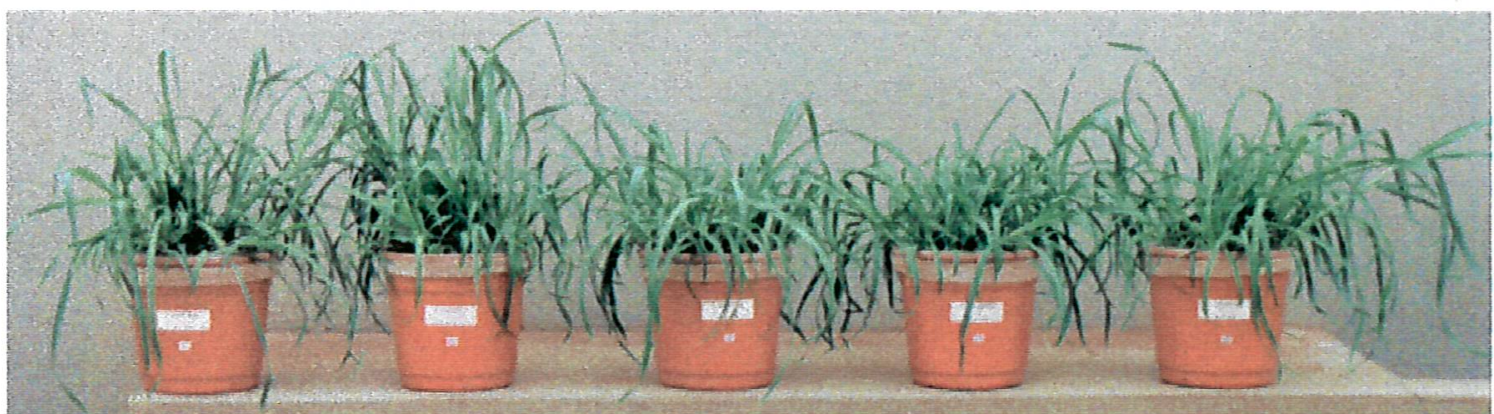

Figura 50- E. polystachya no solo1, ao $1^{\circ}$ Corte. Saturações crescentes da esquerda $p /$ direita.

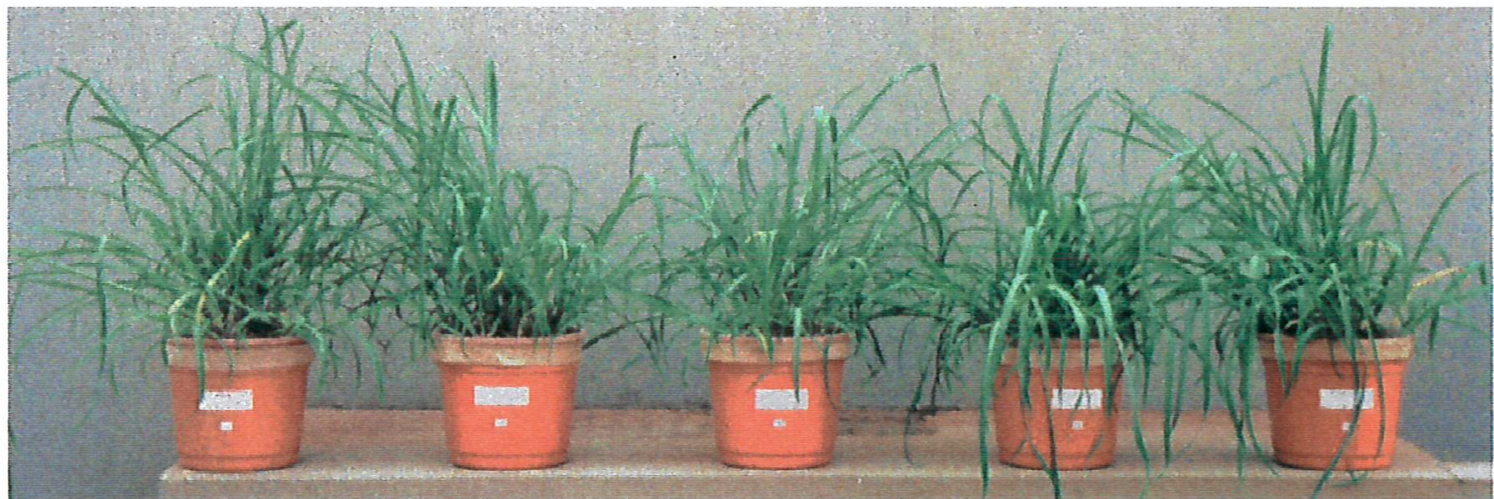

Figura 51- E. polystachya no solo2, ao $1^{\circ}$ Corte. Saturações crescentes da esquerda p/ direita.

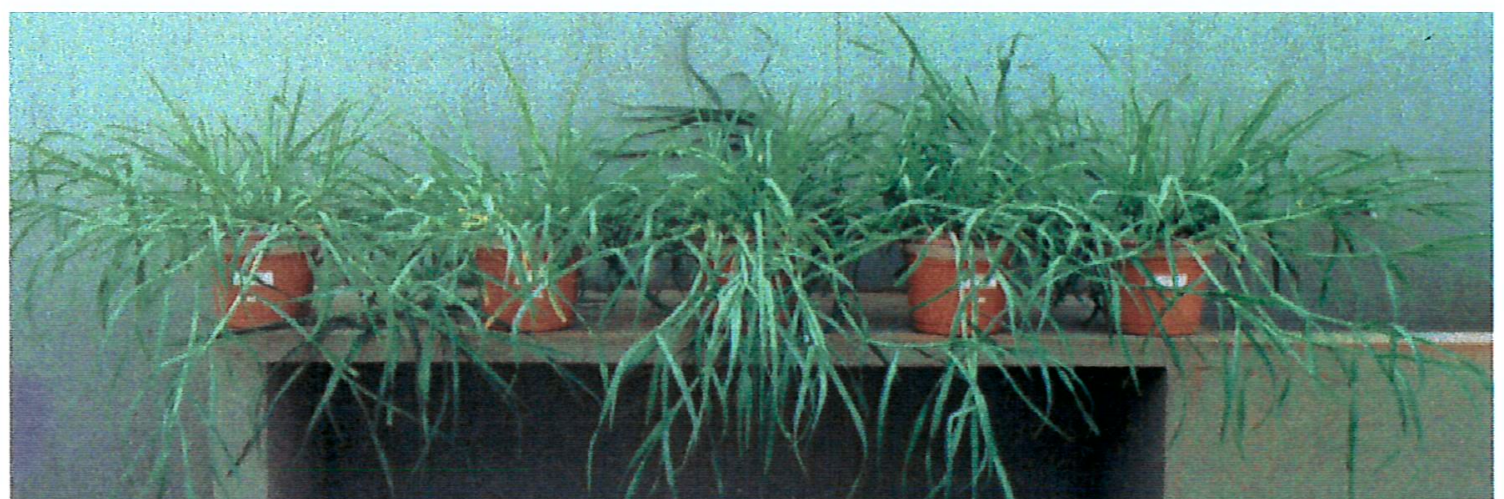

Figura 52- E. polystachya no solo1, ao $3^{\circ}$ Corte. Saturações crescentes da esquerda p/ direita.

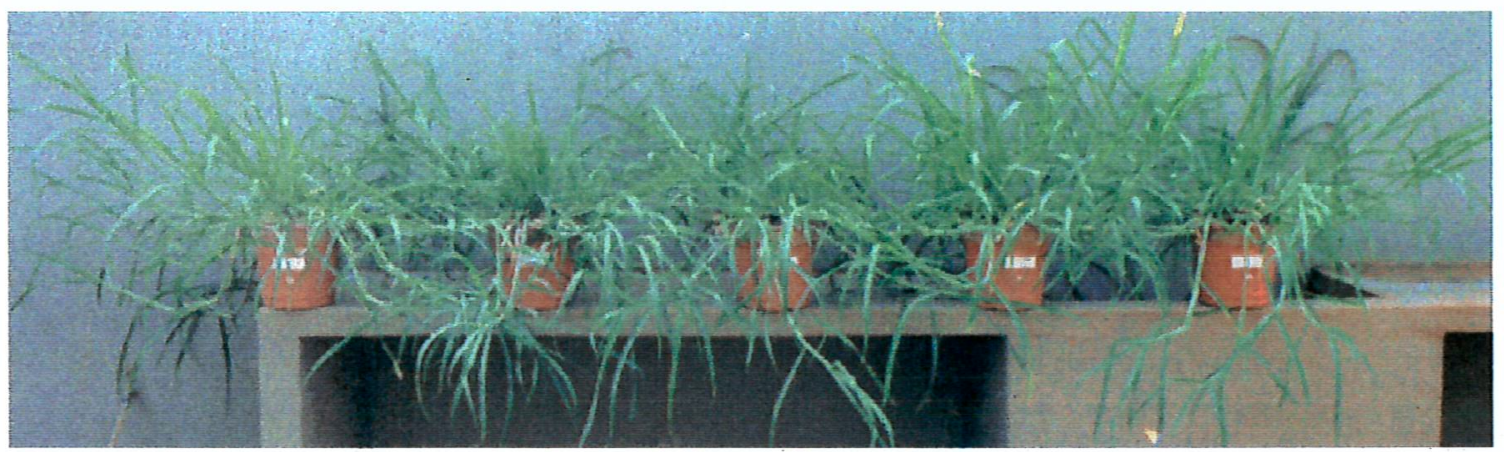

Figura 53- E. polystachya no solo2, ao $3^{\circ}$ Corte. Saturações crescentes da esquerda p/ direita. 


\subsubsection{E. PYRAMIDALIS}

Esta espécie mostrou um comportamento bem diferenciado nos dois solos. Quando cultivada no solo2, no primeiro, segundo e na somatória dos três cortes não houve nenhum efeito benéfico significativo da calagem, havendo inclusive no terceiro corte, um efeito significativo negativo do calcário no parâmetro MNT, mostrando um modelo linear decrescente com o aumento das doses de calcário, que foi acompanhado numericamente pela MST, porém sem significância estatística e também sem interferir significativamente no TMS, apesar ter tido comportamento numericamente inverso.

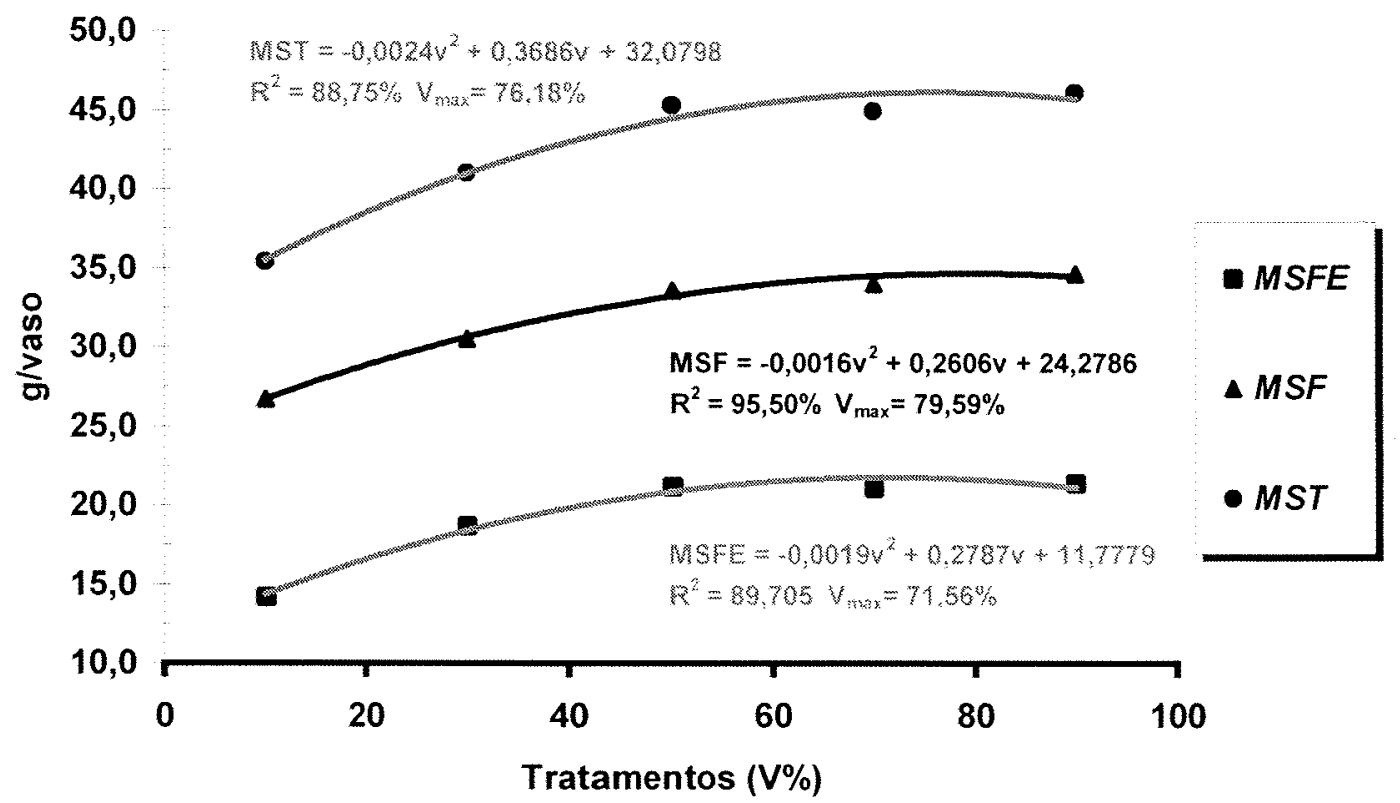

Figura 54- Prarâmetros MST, MSF e MSFE da E. pyramidalis no $3^{\circ}$ corte quando cultivada no solo $1 . V_{\max }$-refere-se a saturação por bases correspondente ao ponto de máxima da curva.

No solo 1, os efeitos da calagem foram acentuado-se ao longo dos cortes, sendo que ao primeiro corte realizado, nenhum efeito foi verificado, porém já no segundo corte houve efeito significativo sobre MSF, explicado por um modelo matemático linear crescente e finalmente no último corte os efeitos foram generalizados em vários 
parâmetros: MNT, MSFE, MSF, MST e AF, todos estes explicadas com modelos quadráticos (Figura 54).

Os efeitos da calagem surgidos no terceiro corte foram tão marcantes que influenciaram na somatória dos 3 cortes nos parâmetros MNT, MSF, MST e ainda na MSR, porém este último parâmetro teve um comportamento completamente inverso ao da parte aérea, de modo que o parâmetro MST $+\mathrm{R}$ não demonstrou efeito significativo, com isto conclui-se que as doses crescentes de calcário influenciaram a alocação de MS entre parte aérea e raízes, favorecendo a parte aérea (Figura 55).

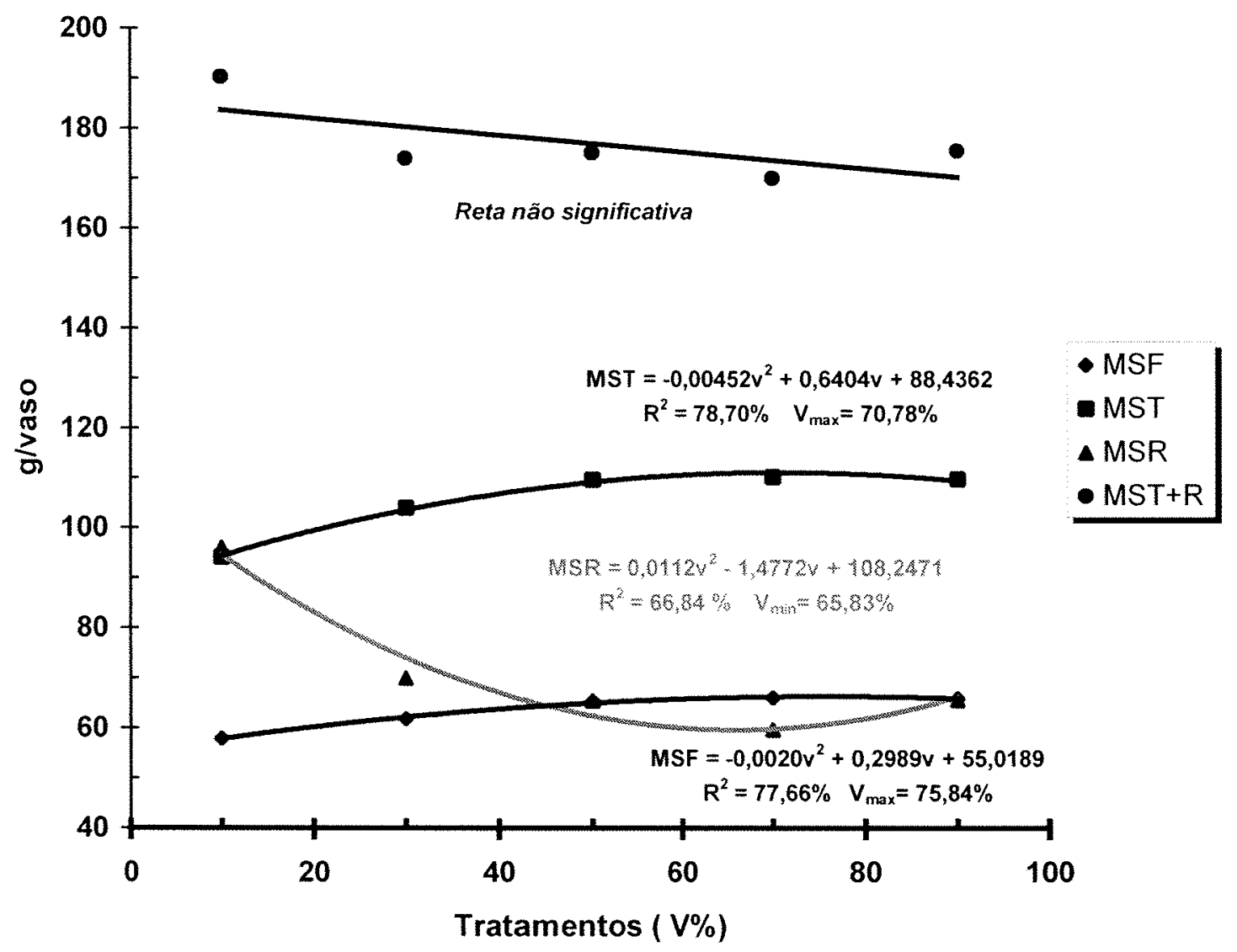

Figura 55- Prarâmetros MST, MSF, MSR e MST+R da E. pyramidalis na somatória das médias dos 3 cortes, quando cultivada no solo $1 . V_{\max }$ refere-se a saturação por bases correspondente ao ponto de máxima da curva. 


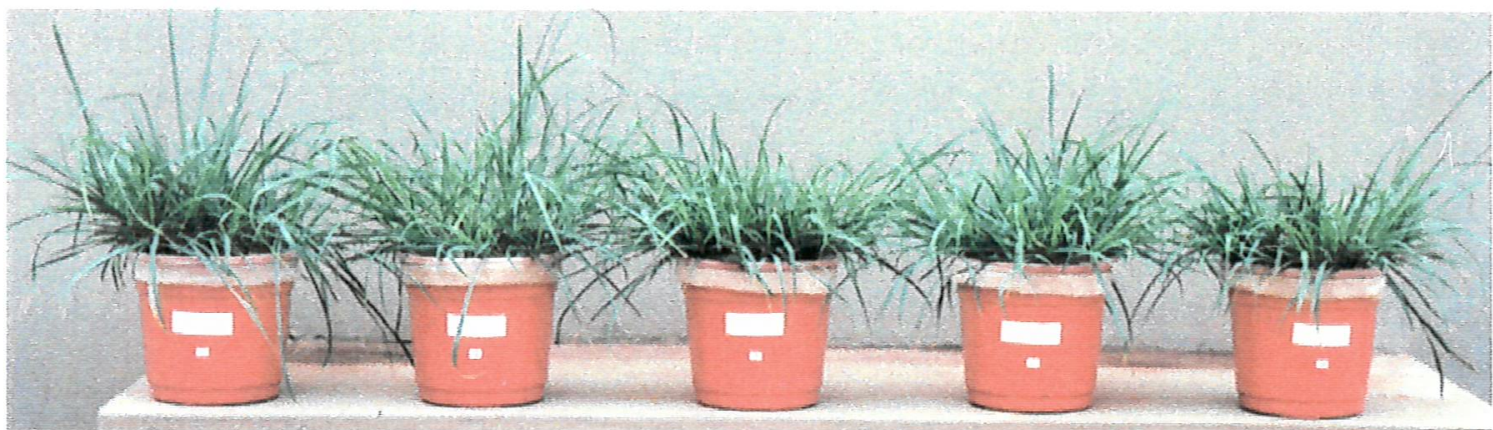

Figura 56- E. pyramidalis no solo1, ao 1ํㅡorte. Saturações crescentes da esquerda p/ direita.

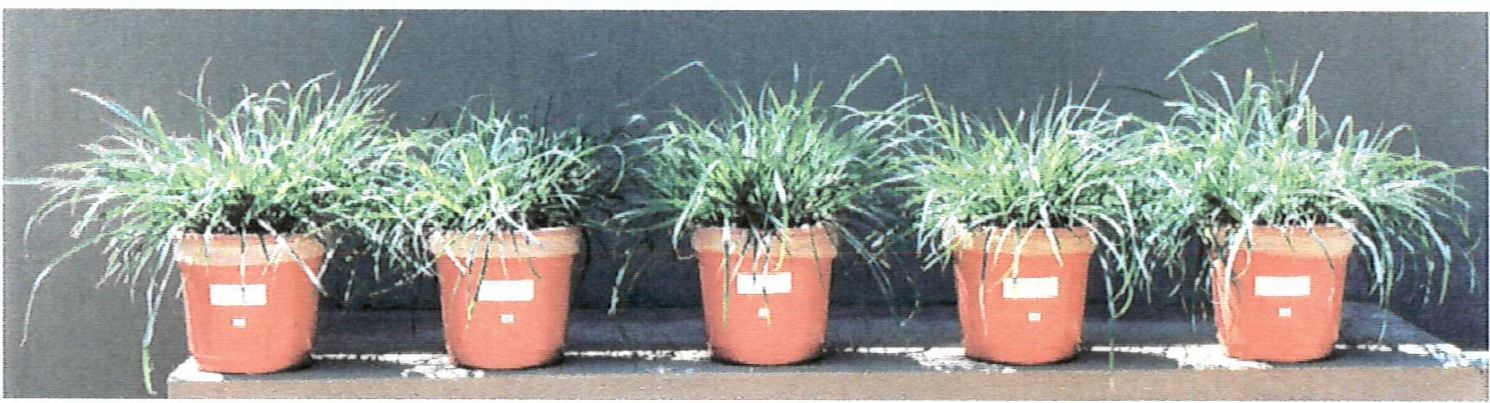

Figura 57- E. pyramidalis no solo2, ao 1ํㅡorte. Saturações crescentes da esquerda p/ direita.

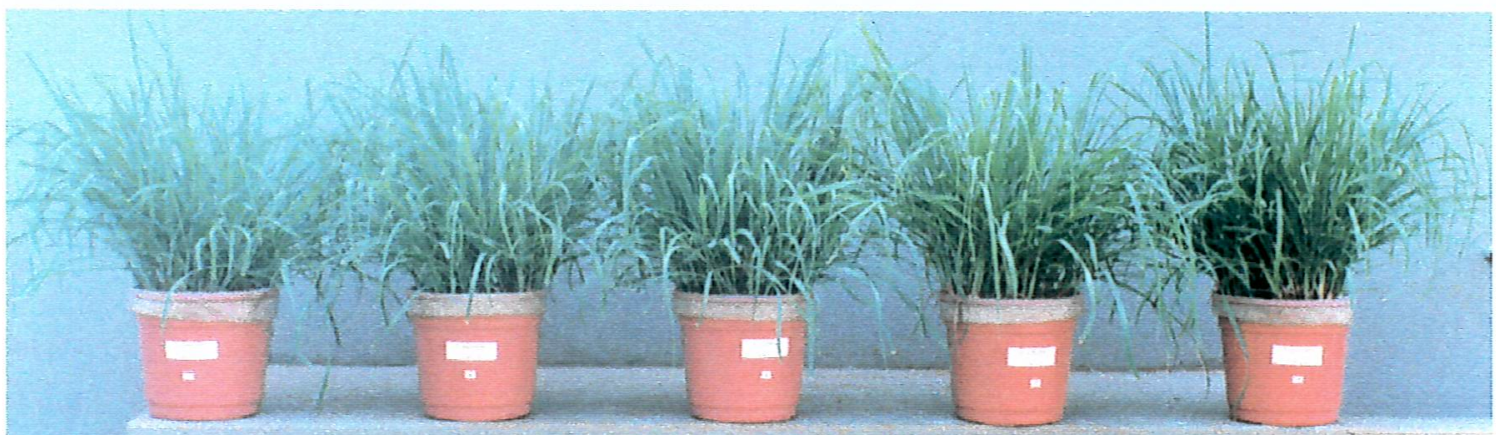

Figura 58- E. pyramidalis no solo1, ao $3^{\circ}$ Corte. Saturações crescentes da esquerda $\mathrm{p} /$ direita.

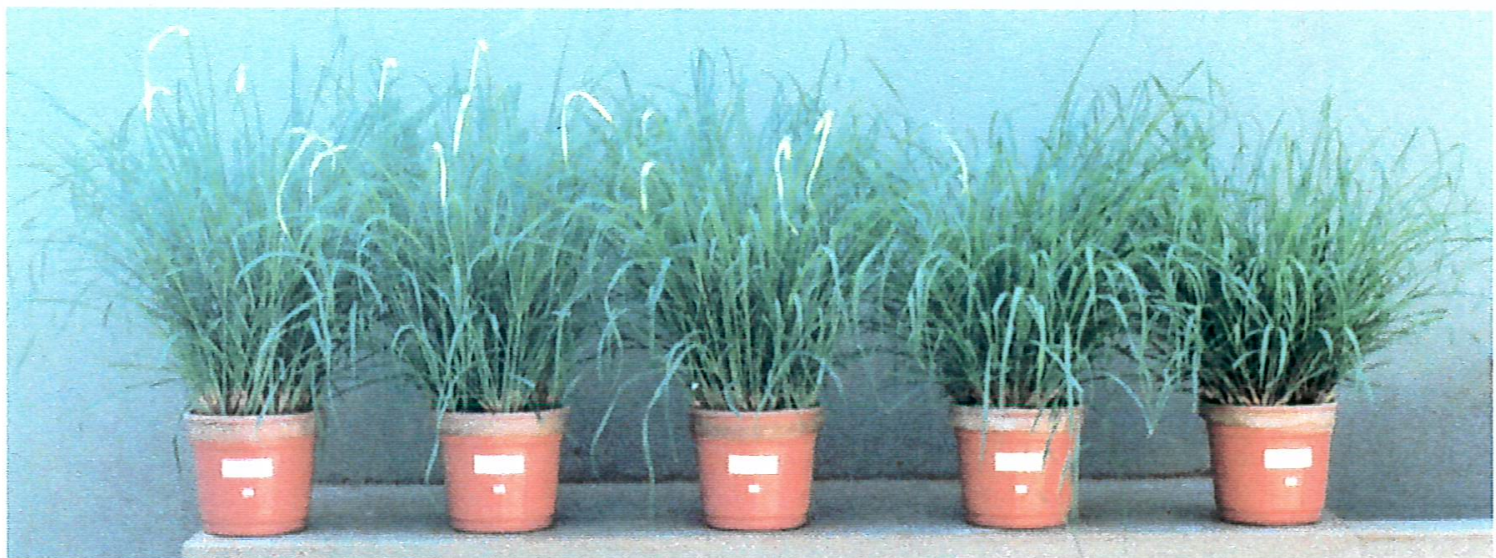

Figura 59- E. pyramidalis no solo2, ao $3^{\circ}$ Corte. Saturações crescentes da esquerda p/ direita. 
Esta distribuição de MS entre parte aérea e raízes, vem a confirmar a adaptação desta espécie a condições de acidez excessiva de solo, ou seja quando a planta teve a sua disposição maior disponibilidade de nutrientes, esta alocou mais fotoassimilados para a parte aérea, por outro lado, quando as condições de solo foram desfavoráveis do ponto de vista de disponibilidade e acidez, a mesma desenvolveu um sistema radicular mais vigoroso na tentativa de melhor extrair os nutrientes limitantes. Este resultado leva a crer que o nível crítico externo de cálcio para o desenvolvimento das raízes desta espécie deva ser bem baixo.

Apesar dos resultados apontados indicarem produções da parte aérea máximas em saturações próximas a $70 \%$, do ponto de vista agronômico, onde mais importante que a produção máxima, deve-se sim buscar a rentabilidade máxima, visualiza-se pelo teste Tukey que a primeira dose de calcário utilizada (V30) já não difere em efeito produtivo das doses maiores, sendo que a maior produção alcançada (V70) foi apenas $6,3 \%$ superior a verificada no tratamento V30. Assim como para a E. polystachya, em nenhum momento foi verificado efeito significativo para o perfilhamento desta espécie.

Outro efeito importante observado para a E. pyramidalis quando cultivada no solo1 foi o efeito significativo no parâmetro TMS ocorrido no terceiro corte. Este efeito pode ser verificado visualmente na última semana antes do corte, pois as plantas das parcelas do tratamento testemunha apresentavam-se murchas nos horários mais quentes do dia entre $11 \mathrm{~h}$ e $15 \mathrm{~h}$ (Figura 81, no item teores de $\mathrm{Ca}$ ). Este comportamento pode ser atribuído a uma deficiência de cálcio, visto que o mesmo está intimamente relacionado com o fechamento estomático (Karp, 1996), deficiências neste elemento poderão causar retardamento no mecanismo de fechamento estomático o que levará a uma condição de perda excessiva de água nas horas mais quentes do dia pelo vegetal.

\subsubsection{B. MUTICA}

Foi sem dúvida a espécie que mais se beneficiou da calagem e assim como a $E$. pyramidalis mostrou um comportamento bem diferenciado entre os dois solos utilizados. Cultivada no solo1, teve um comportamento bem semelhante a E. pyramidalis, quando 
cultivada neste mesmo solo, ou seja, mostrou efeitos positivos da calagem, que formam acentuando-se ao longo dos corte. No primeiro corte, ocorreram efeitos significativos nos parâmetros MSFEE e MSF, porém nenhum modelo, linear ou quadrático foi significativo para explicar o fenômeno, sendo que numericamente o melhor tratamento para estes dois parâmetros foi o V30. No segundo corte a MNT obedeceu a um modelo matemático linear crescente. No terceiro e último corte, os efeitos foram generalizados em vários parâmetros: MNT, MSH, MST e AF, que apresentaram modelos quadráticos significativos com pontos de máxima e ainda tendo os parâmetros: MSF e MSFE explicados por modelos lineares crescentes, sendo que o comportamento de alguns destes podem ser visualizados na Figura 60, neste corte foi possível visualizar incrementos na MST de 52,4\% para o tratamento V70 em relação à testemunha. E ainda neste mesmo corte foi verificado efeito significativo no perfilhamento.

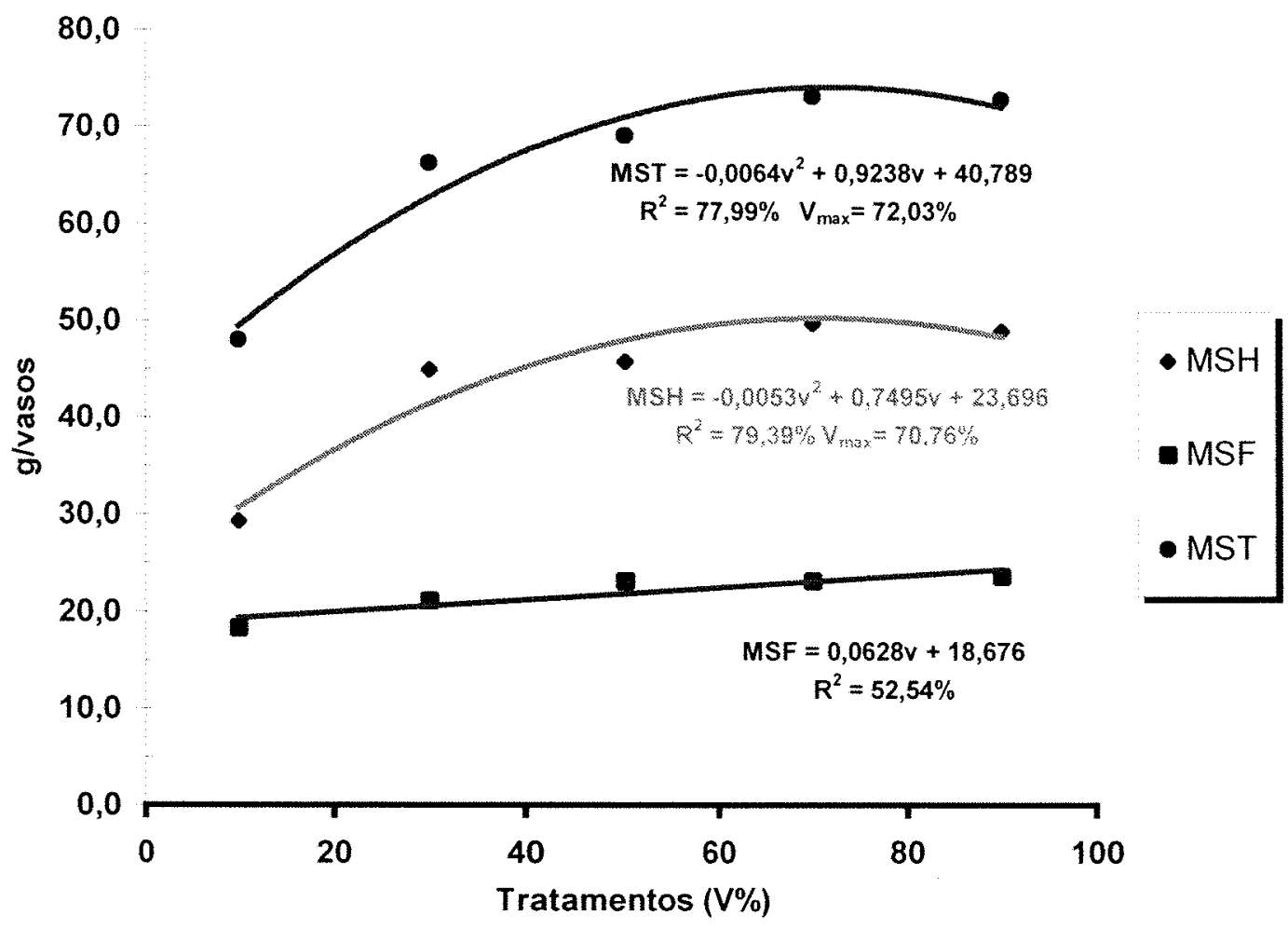

Figura 60- Prarâmetros MST, MSH e MSF da B. mutica no $3^{\circ}$ corte, quando cultivada no solo 1. $V_{\max }-$ refere-se a saturação por bases correspondente ao ponto de máxima da curva. 
Os efeitos verificados no último corte acabaram por refletir na produção total dos 3 cortes nos parâmetros: MNT, MSF, MSH, MST e MST $+R$, todos este explicados por equações quadráticas com ponto de máxima próximo a $70 \%$ de saturação por bases (Figura 61). Porém, mais uma vez lançou-se mão de um teste de comparação de média (Tukey), que mostrou assim como ocorrido para espécie E. pyramidalis, apenas diferença estatística entre a testemunha e os demais tratamentos, que foram igualmente superiores, com isto verifica-se não ser vantajoso para a produção desta espécie, quando cultivada no solo1, saturações por bases acima de 30\%. Tendo ocorrido um aumento numérico de apenas $10 \%$ entre o tratamento V30 e a máxima produção obtida (V70).

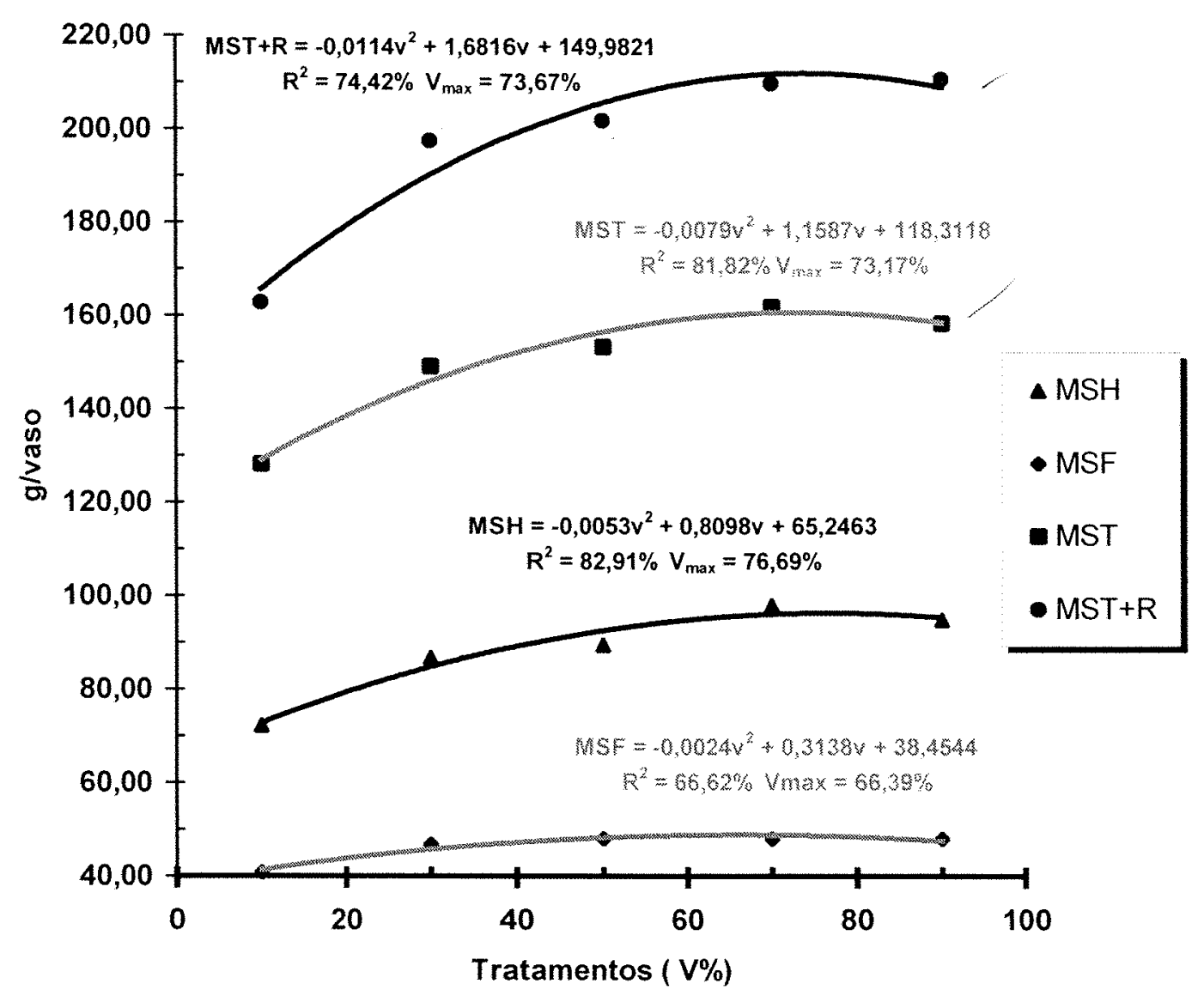

Figura 61- Prarâmetros MST, MSH, MSF e MST+R da $B$. mutica, no somatório das médias dos 3 cortes, quando cultivada no solo 1 . $V_{\max }$ refere-se a saturação por bases correspondente ao ponto de máxima da curva. 
Na somatória dos 3 cortes, o parâmetro folha:haste foi reduzindo-se com as doses crescentes de calcário (Figura 62). Isto pode ser explicado, já que aumentos na produção total estiveram associados ao desenvolvimento de perfilhos visivelmente maiores (aumento de produção sem contudo existir reflexo significativo no número de perfilhos produzidos), mostrando um comportamento de maior elongação de haste (hastes mais longas e também com maior diâmetro), o que acaba por traduzir em uma pior relação folha:haste concomitante com os aumentos nas doses de calcário.

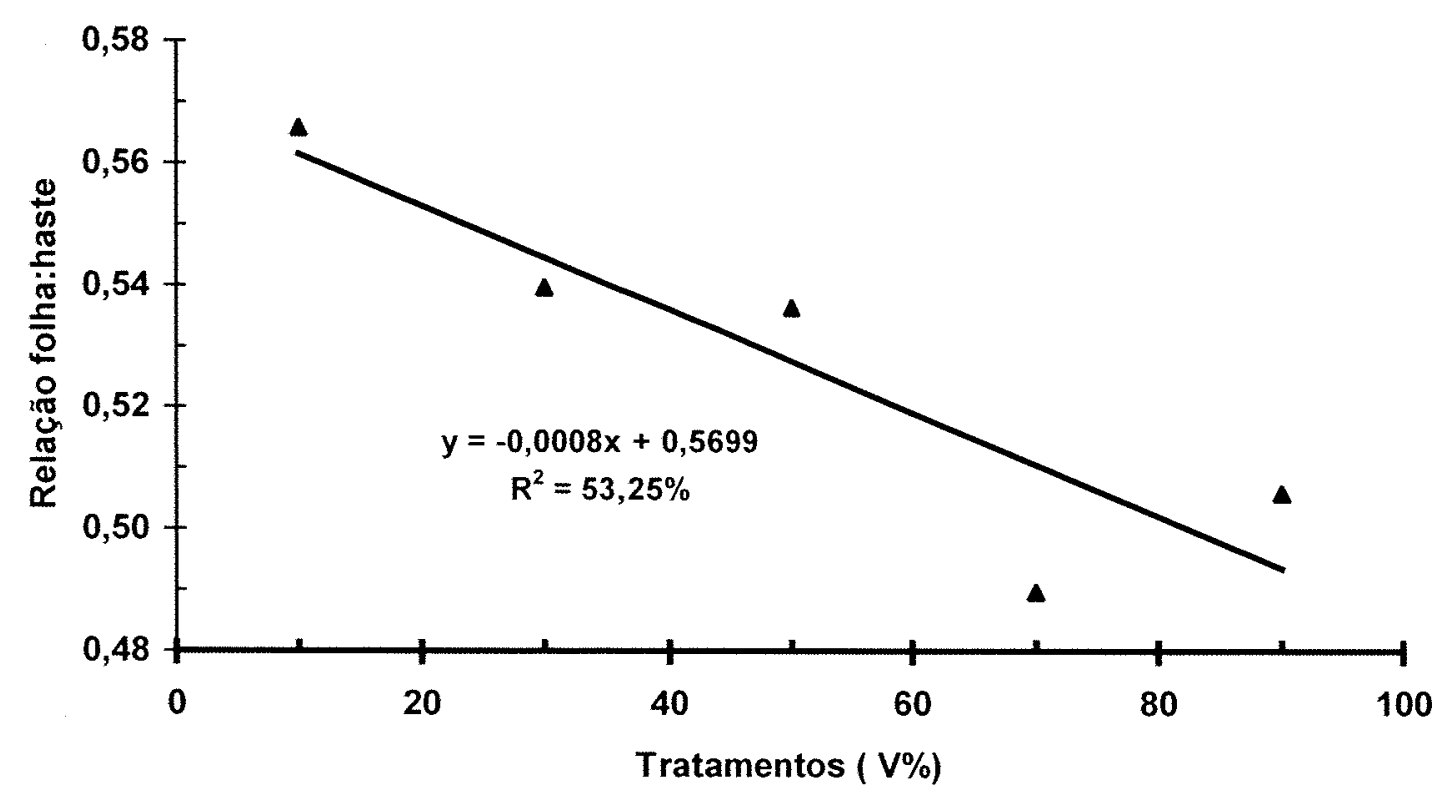

Figura 62- Realção folha:haste da B. mutica no $3^{\circ}$ corte, quando cultivada no solo 1.

Cultivada no solo 2, a Brachiaria mutica, demonstrou um comportamento bem diferenciado das outras espécies, mostrando fortes efeitos benéficos da calagem já no 1 corte para todos os parâmetros, com exceção da RFH e do TMS (Figura 63), que praticamente desapareceram no segundo corte, mostrando apenas efeito no parâmetro NP. No terceiro corte houve novamente efeito significativo no parâmetro MST, porém com bem menor intensidade que o observado no $1^{\circ}$ corte. E finalmente, na produção total existiu efeitos para os parâmetros MNT, MSF, MSH, MST, MSR e MST+R (Figura 64). 
A possível explicação para o comportamento diferenciado desta espécie em relação às demais, quando cultivada no solo 2 , ou seja, mostrando um grande efeito da calagem no primeiro corte (tratamento V75 produziu $161,2 \%$ a mais que a testemunha) e menor efeito nos cortes subseqüente, pode ser explicado pela menor capacidade desta espécie em lidar com grandes diferenças na relação $\mathrm{Ca}: \mathrm{Mg}$ do solo, como é o caso do solo2, aonde o $\mathrm{Mg}$ chega a estar em concentrações superiores a 6,8 vezes o teor de cálcio. Maiores discussões sobre esta possível causa serão traçadas na discussão dos resultados dos teores de $\mathrm{Ca}$ e $\mathrm{Mg}$ encontrados nas folhas, bem como a relação existente entre os mesmos, alem da apresentação de sintomas de deficiência de cálcio.

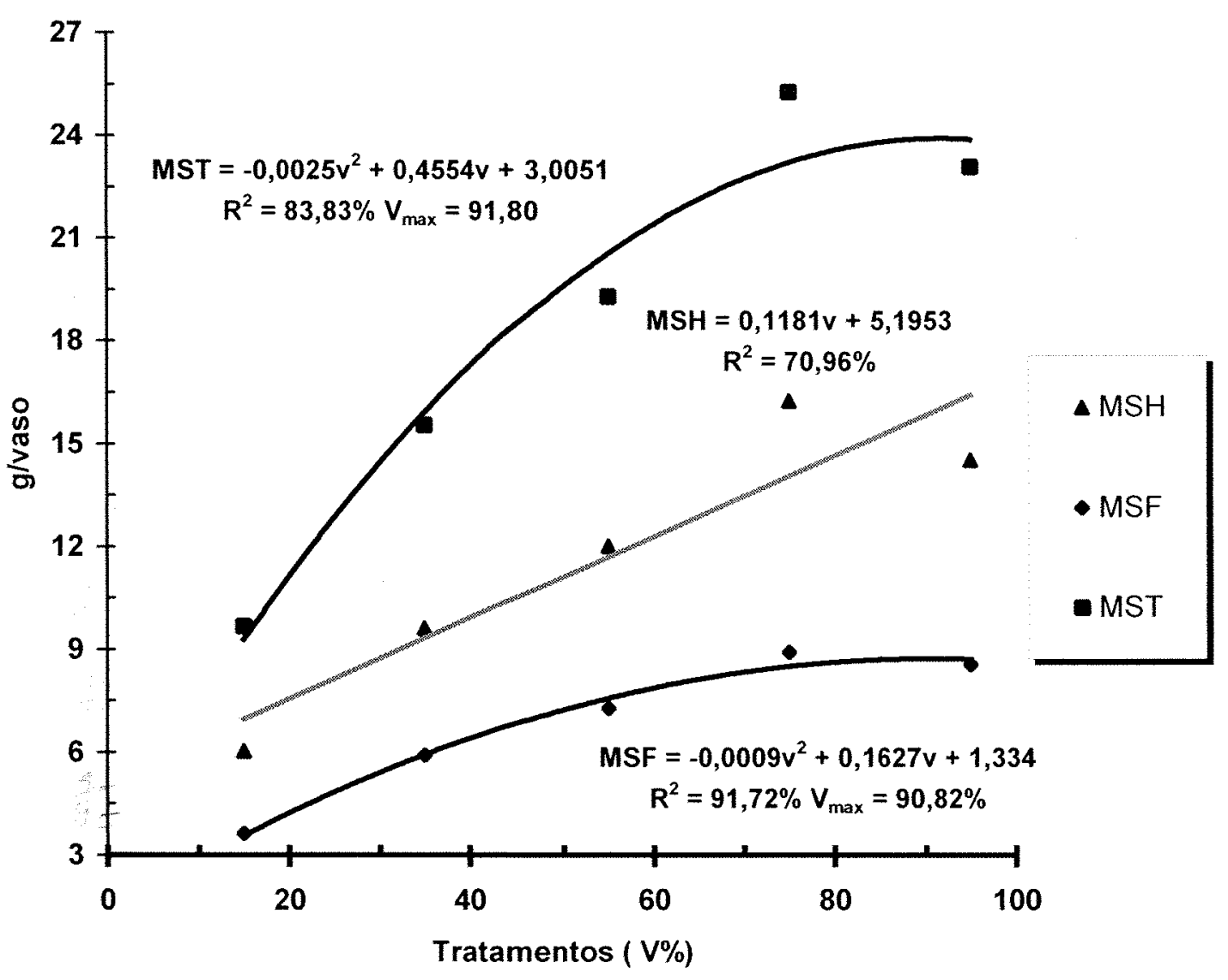

Figura 63- Prarâmetros MSF, MSH e MST da B. mutica, no $1^{\circ}$ corte, quando cultivada no solo $1 . V_{\max }$-refere-se a saturação por bases corespondente ao ponto de máxima da curva. 
Mas uma vez, apesar do modelo linear crescente explicar melhor muitos dos parâmetros da produção total (soma dos 3 cortes) no solo 2, os incremento para MST foram pequenos com o aumento das doses de calcário (Figura 64). E ao analisar os dados com auxílio teste Tukey, novamente se verifica uma diferença estatística somente entre o tratamento testemunha que foi inferior aos demais, sendo os demais iguais entre si. Não sendo provavelmente, do ponto de vista econômico, vantajoso elevar a saturação de bases acima de $35 \%$, já que acima deste valor o máximo que se conseguiu em aumento de produção foi de $6,2 \%$.

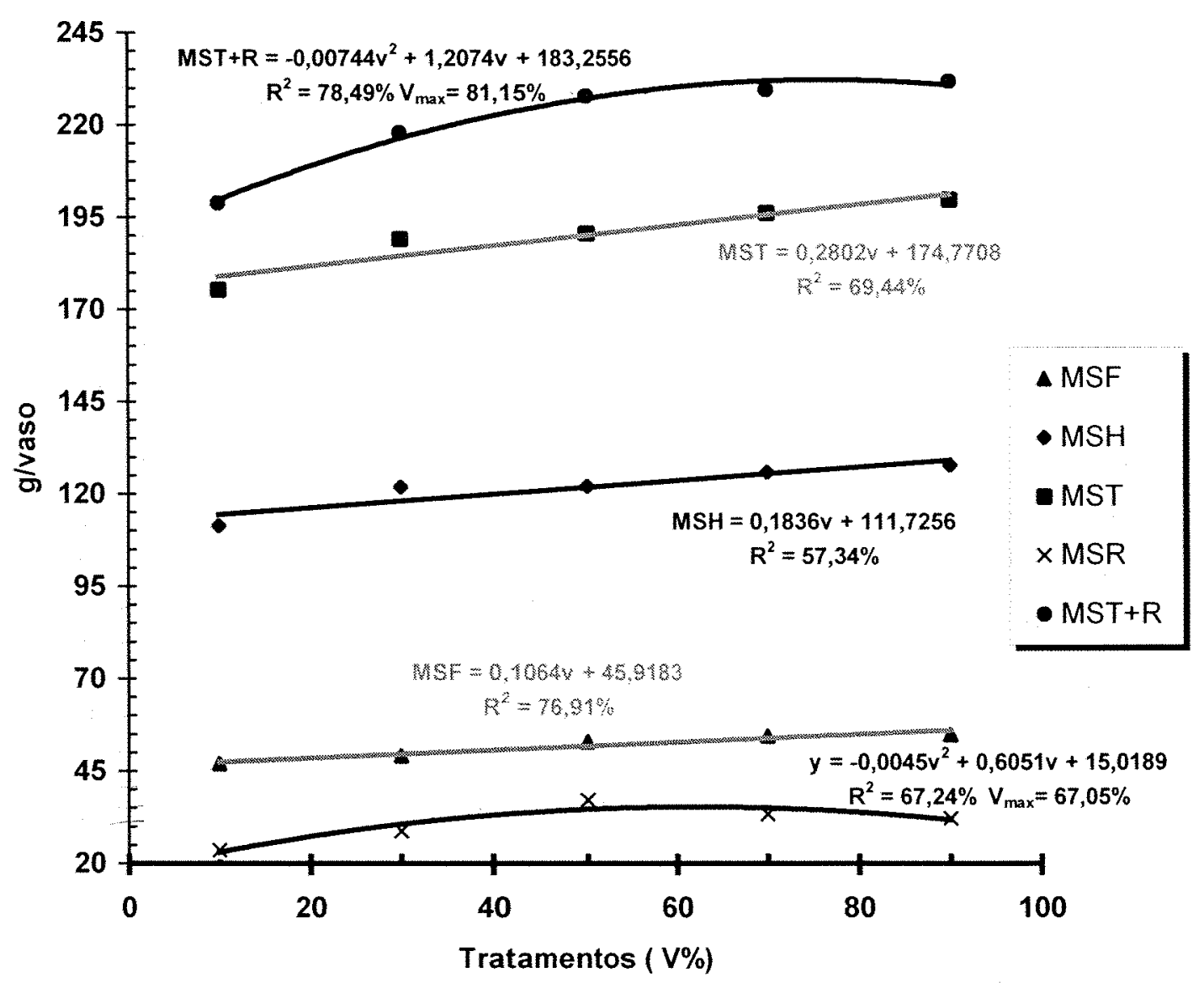

Figura 64- Prarâmetros MST, MSH, MSF, MSR e MST+R da B. mutica, somatório das médøas dos 3 cortes, quando cultivada no solo 2 . $V_{\max }$-refere-se a saturação por bases correspondente ao ponto de máxima da curva. 


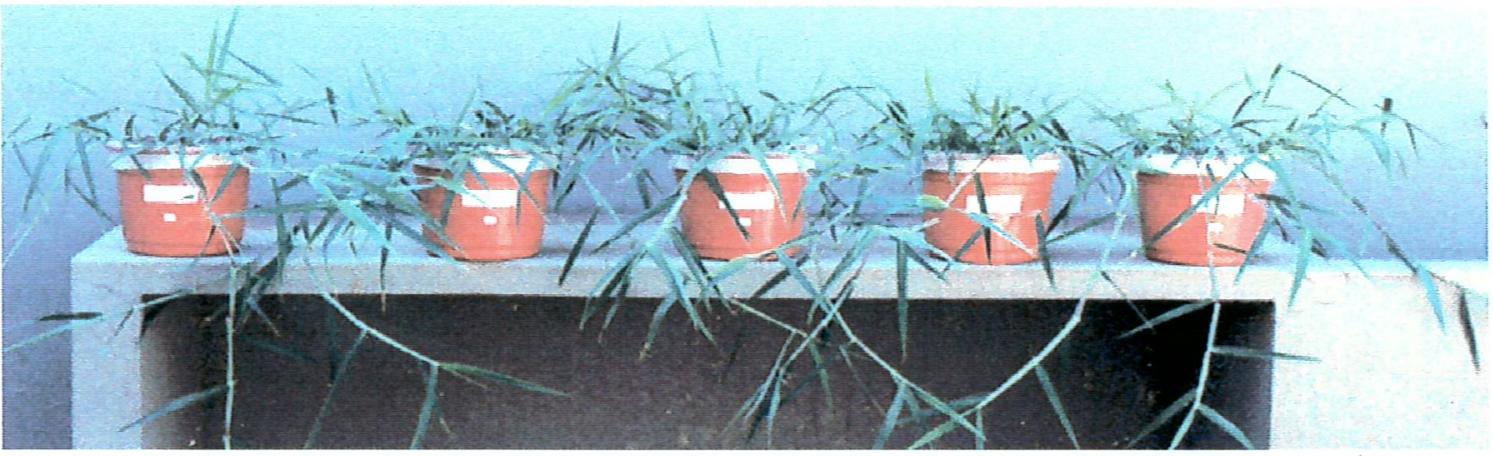

Figura 65- B. mutica no solo1, ao 1ํCorte. Saturações crescentes da esquerda p/ direita.

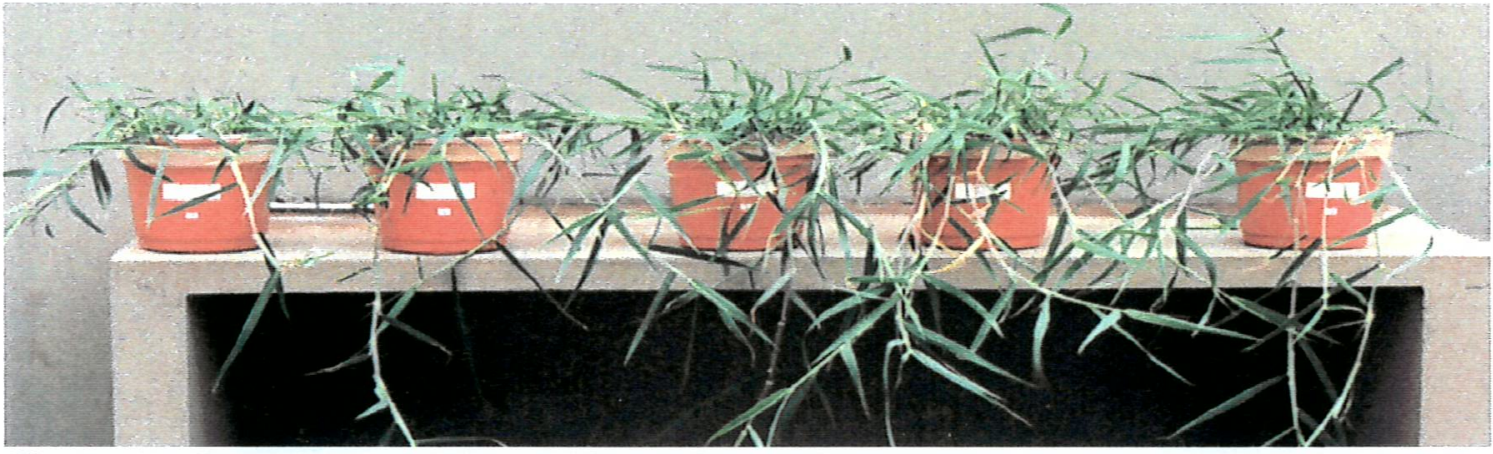

Figura 66- B. mutica no solo2, ao 1ํCorte. Saturações crescentes da esquerda p/ direita.

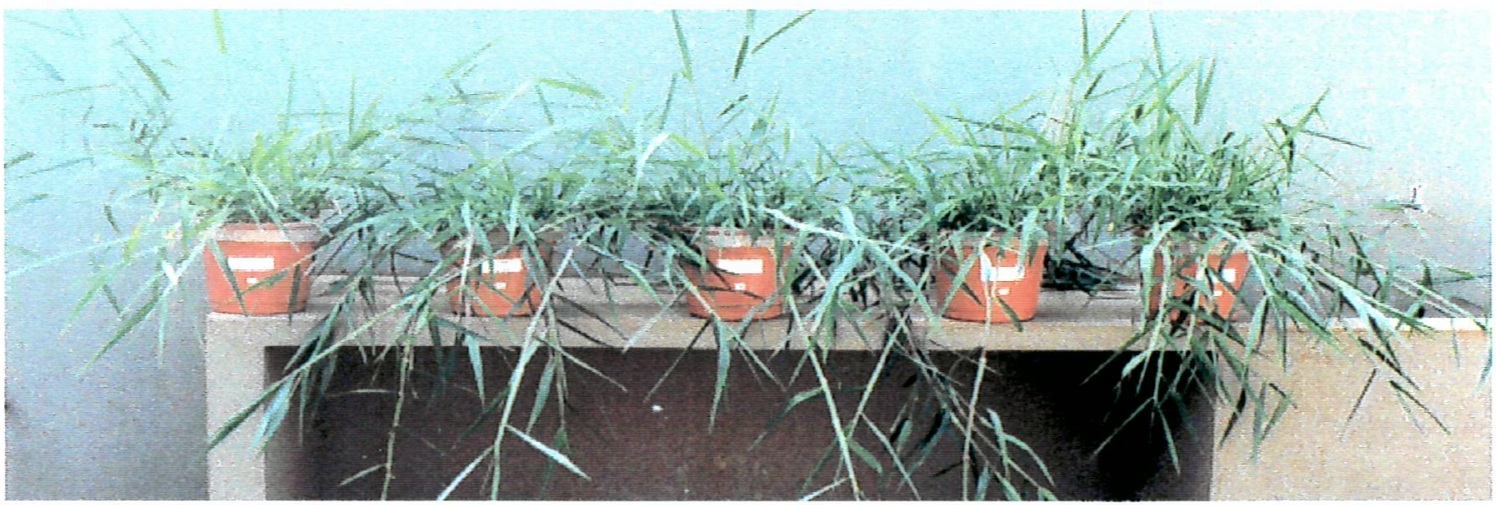

Figura 67- B. mutica no solo1, ao 3Corte. Saturações crescentes da esquerda $\mathrm{p} /$ direita..

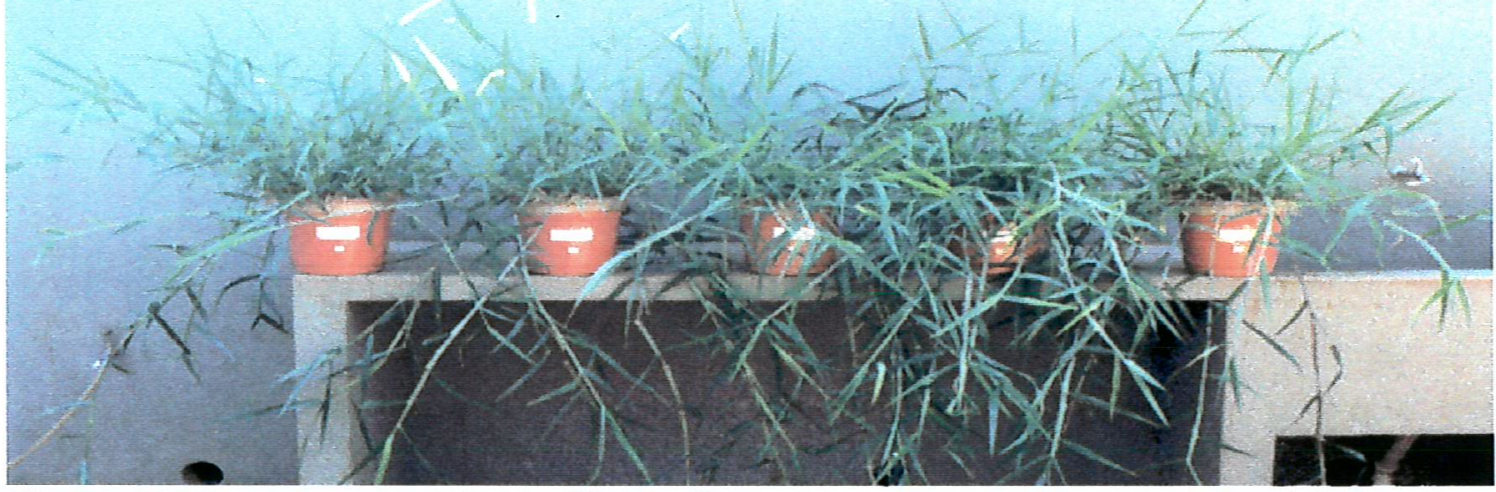

Figura 68- B. mutica no solo2, ao $3^{\circ}$ Corte. Saturações crescentes da esquerda p/ direita. 
Esta foi a única espécie que foi favorecida pela calagem, com aumentos numéricos crescentes na produção de raízes quando cultivada no solol e aumentos estatisticamente significativos no solo2, neste último, explicado por um reta crescente em função de doses crescentes de calcário (Figura 64). Isto demonstra claramente que esta espécie é mais sensível à acidez (Al e possivelmente $\mathrm{Mn}$ ) e a deficiência de Ca no solo (ou ainda competição deste com outras bases) quando comparada às demais.

O parâmetro NP foi aparentemente (já que não houve confronto estatístico entre solos) influenciado pelo tipo de solo, já que no solo2 tivemos 3 ocorrências significativas, contra apenas uma no solo1 e com comportamento totalmente inverso. No solo 2 houve um maior número de perfilhos no tratamento testemunha, possivelmente devido a morte do meristema apical de muitos perfilhos causada pela deficiência de cálcio apresentada por esta espécie, quando cultivada neste solo (Figura $\mathbf{8 0}$, no item composição mineral - Ca), esta morte do meristema, quebra a dominância apical, e permite que gemas basilares saiam do estádio de dormência, produzindo novos perfilhos e assim causando maiores perfilhamento justamente nas parcelas com menor disponibilidade de Ca para a planta. De modo inverso no solol o tratamento testemunha teve um menor número significativos de perfilhos, possivelmente, associado a menor produção de MS em todos os parâmetros, ocorrido justamente no terceiro corte, onde o solo já se encontrava excessivamente acidificado, exaurido de $\mathrm{Ca}$ e $\mathrm{Mg}$ e ainda possuindo elevados teores de $\mathrm{Al}$. Fotos e maiores discussões sobre estas deficiências e/ou toxidez serão apresentadas no item composição mineral.

\subsubsection{B. HUMIDICDLA}

Esta espécie apesar de pertencer ao mesmo gênero da B. mutica teve um comportamento completamente oposto, mostrando mais efeito negativos da calagem do que favoráveis. Quando cultivada no solo 2, teve como único efeito estatisticamente significativo ocorrido na área foliar medida no segundo corte, tendo apresentado decréscimos com as doses crescentes de calcário, resultado que foi acompanhado 
numericamente com pelas MSFE, MSFEE e MSF, porém sem significância estatística. (Figura 65).

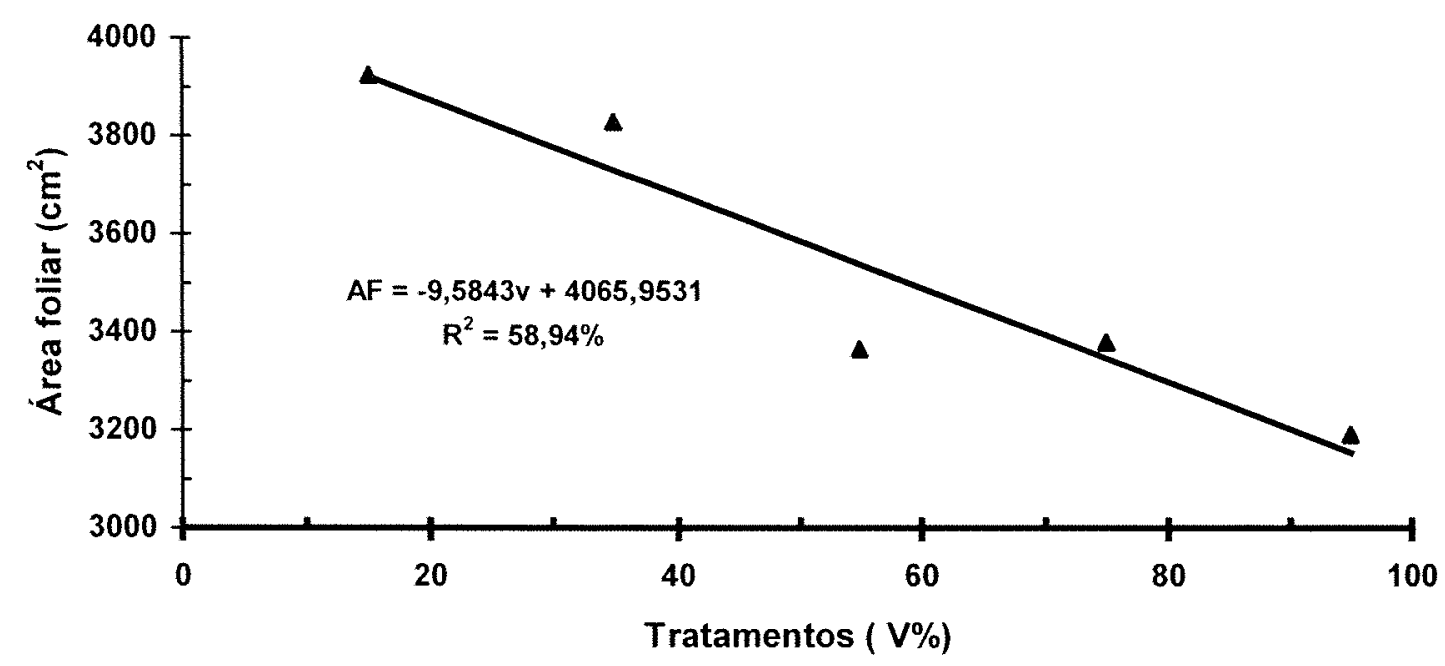

Figura 65- Área foliar da B. humidicola no $2^{\circ}$ corte, quando cultivada no solo 2.

No solol a calagem foi prejudicial à produção no primeiro corte, mostrando para todos os parâmetros diretamente determinados reduções lineares (Figura 66). No segundo corte, os parâmetros MNT e MST tiveram um comportamento explicado por modelos quadráticos com pontos de máxima, contudo apesar da MST ter apresentado valor máximo de produção na saturação de $52,41 \%$, teve um péssimo modelo para explicar tal comportamento $\left(R^{2}=19,93 \%\right)$.

E finalmente na somatória de todos os cortes, mostrou novamente efeitos significativos negativos para perfilhamento (Figura 67). Quanto ao desenvolvimento radicular foram observados decréscimos lineares para a MSR com o aumento das doses de calcário, sendo que a produção de raízes do tratamento testemunha foi quase o dobro daquela observada para o tratamento V90 (Figura 72). Fenômeno este que confirma, o já observado na espécie E. pyramidalis, ou seja, a grande capacidade que muitas forrageiras tropicais possuem em desenvolver sistema radicular abundante mesmo em condições ditas desfavoráveis para a maioria das espécies vegetais. 


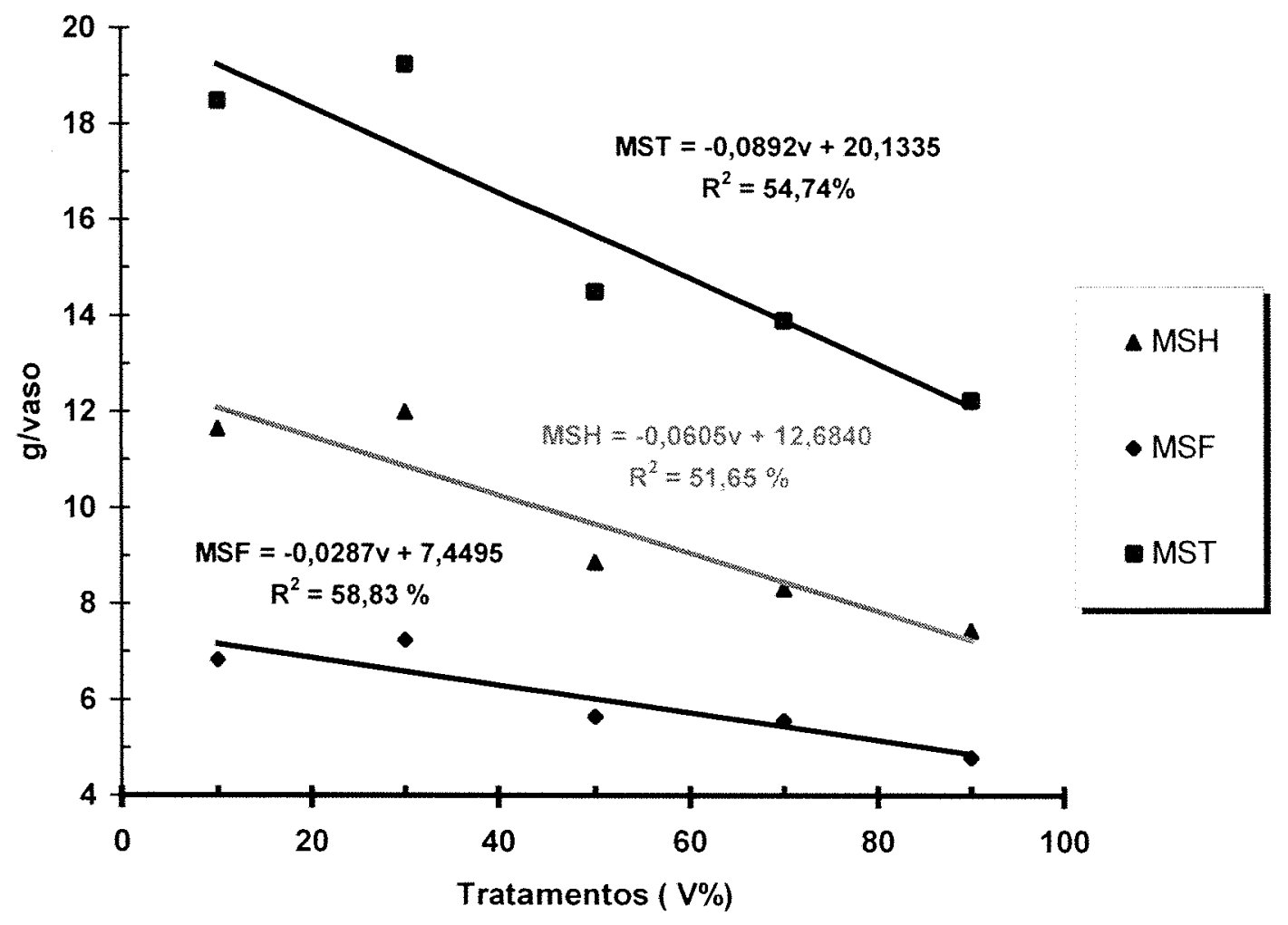

Figura 66- Produçãoda $B$. humidicola no $1^{\circ}$ corte, quando cultivada no solo 1.

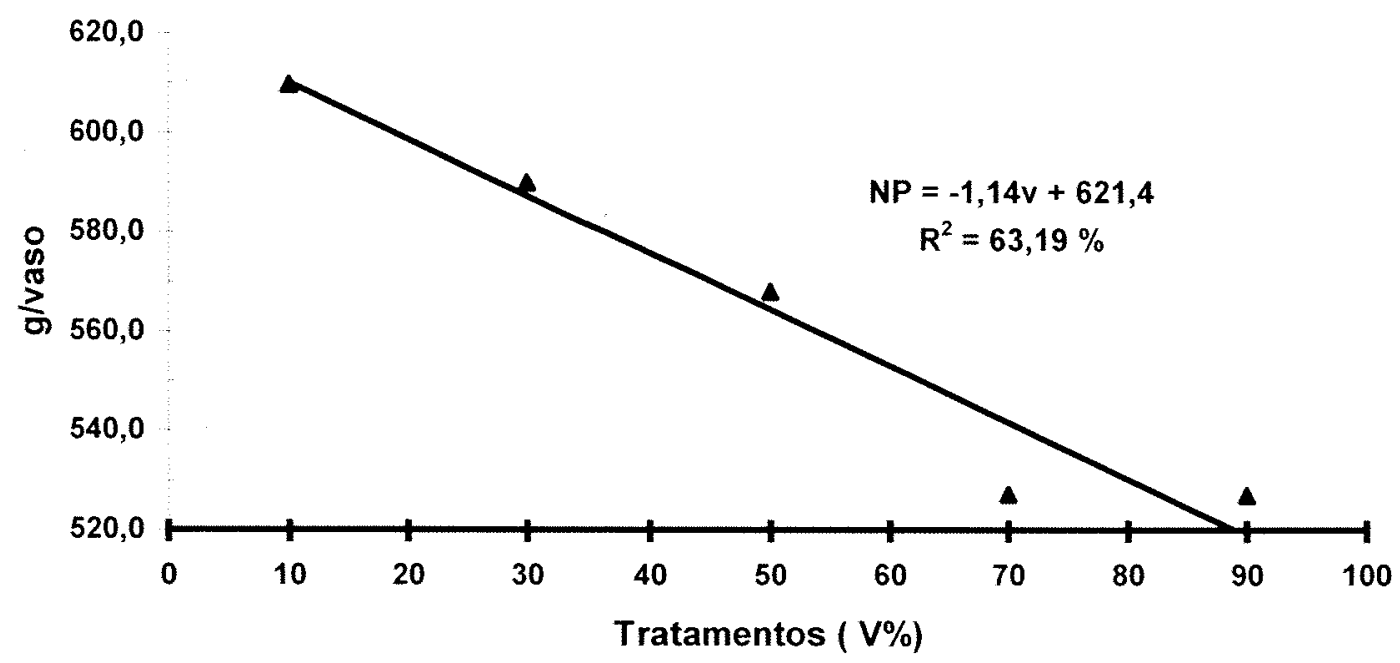

Figura 67- Número de perfilhos da B. humidicola na somatória dos 3 cortes, quando cultivada no solo 1. 


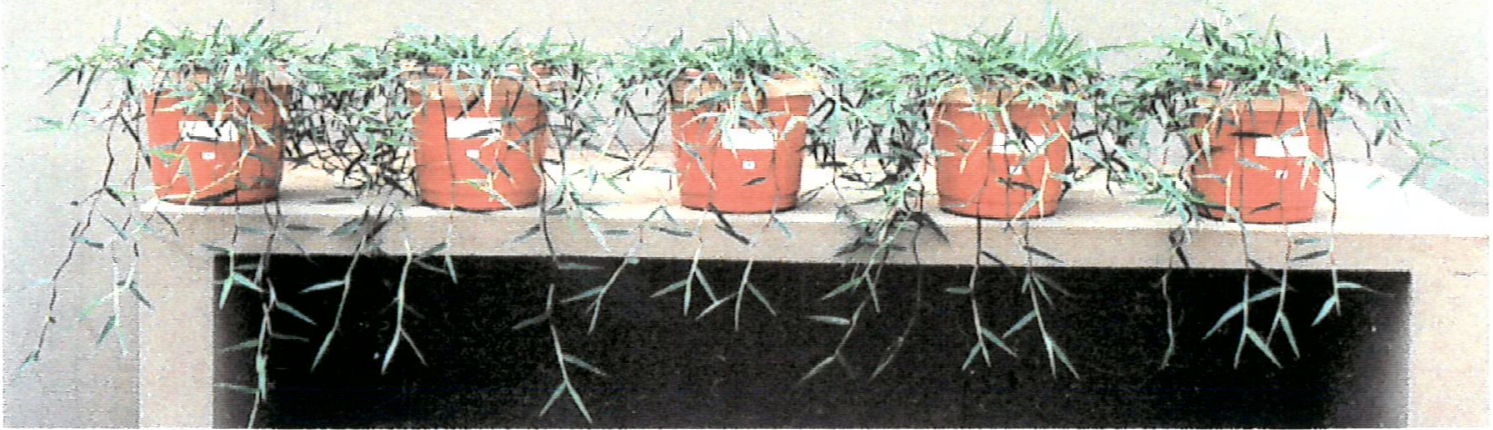

Figura 68- B. humidicola no solo1, ao 1ํCorte. Saturações crescentes da esquerda p/ direita.

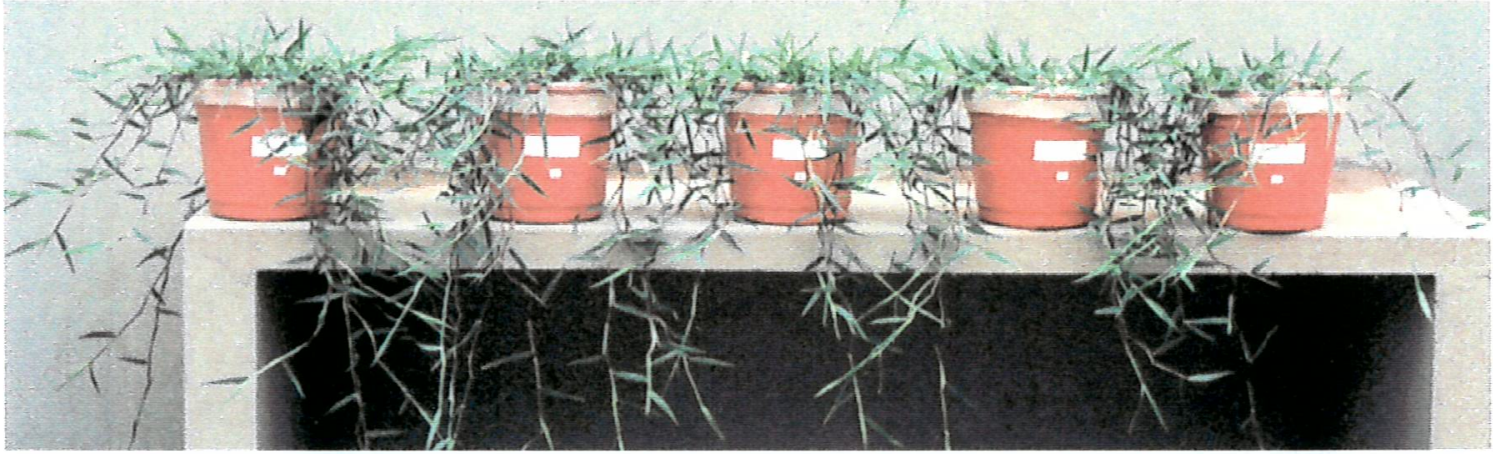

Figura 69- B. humidicola no solo2, ao $1^{\circ}$ Corte. Saturações crescentes da esquerda p/ direita.

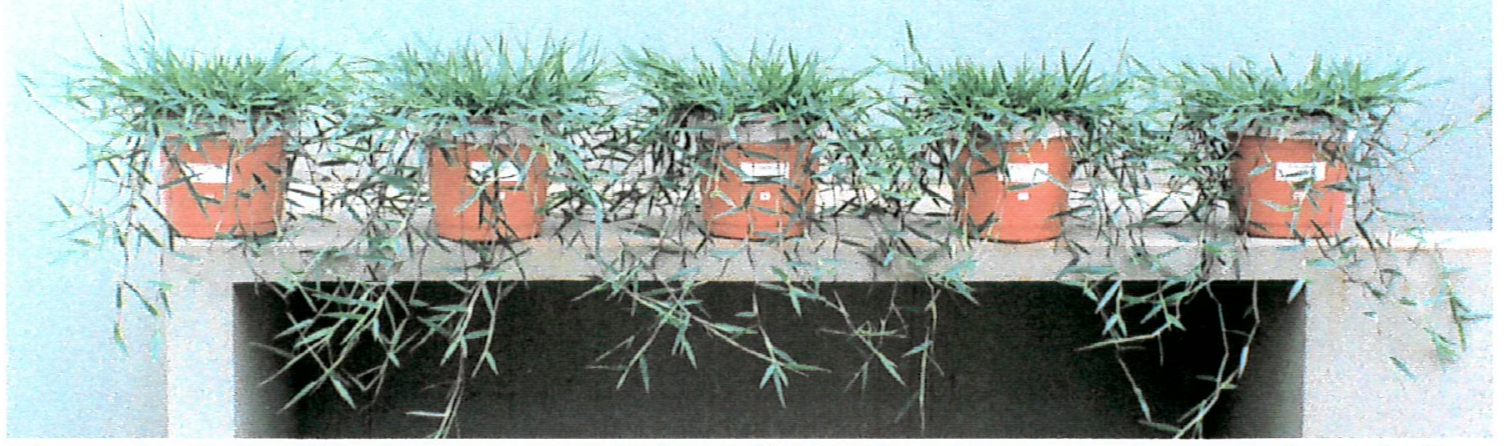

Figura 70- B. humidicola no solo1, ao $3^{\circ}$ Corte. Saturações crescentes da esquerda p/ direita.

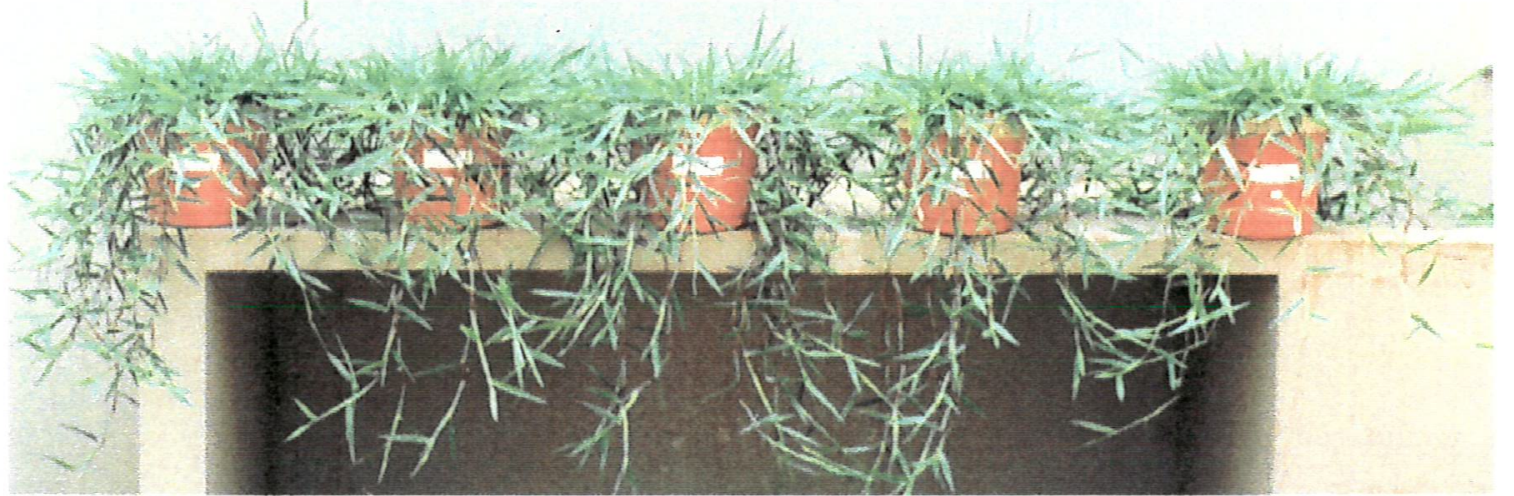

Figura 71- B. humidicola no solo2, ao $3^{\circ}$ Corte. Saturações crescentes da esquerda $p /$ direita. 


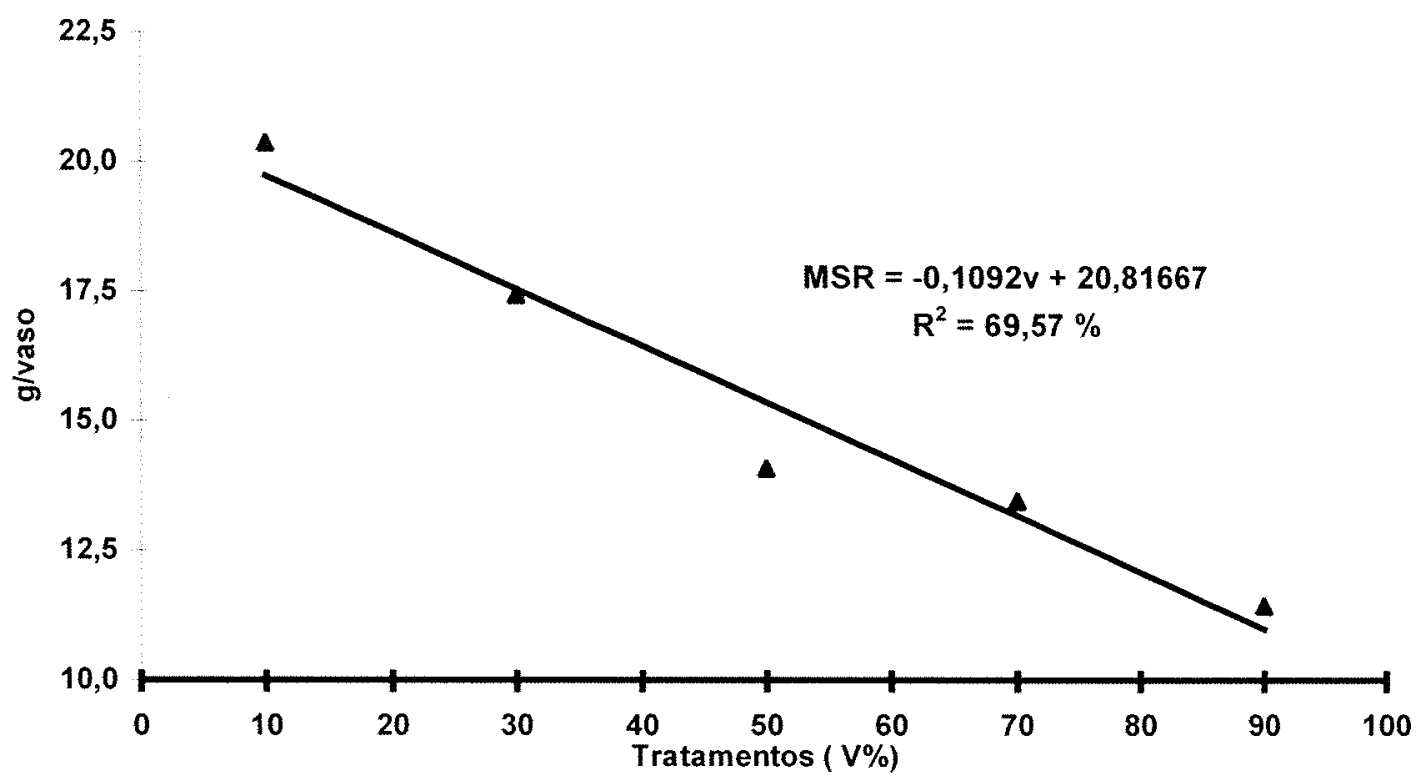

Figura 72- Produção de raizes da B. humidicola, quando cultivada no solo 1.

\subsubsection{CINSIDERAÇÕES FINAIS SLBRE A PRIDUÇÃa}

O primeiro aspecto geral dos resultados obtidos para produção de matéria seca revela a clara diferença entre espécies quanto à exigência em necessidade de calagem, não sendo possível sequer agrupar espécies do mesmo gênero, com a mesma recomendação. Visto que a $B$. mutica foi a espécie que mais se beneficiou da calagem, ao contrário de $B$. humidicola que apesar de pertencer ao mesmo gênero, teve um comportamento completamente oposto, ou seja, na maioria das ocasiões foi prejudicada pelas crescentes doses de calcário empregadas.

Esta diferença entre espécies e até mesmo entre cultivares à condições de acidez do solo é amplamente reconhecida na literatura (Lotero et al., 1971; Spain \& Andrew, 1976; Siquira, 1986; Premazzi, 1991; Mitidieri, 1995). Existindo na literatura inclusive algumas tentativas de classificação de forrageiras quanto à exigência em calagem (Siquira, 1986; Werner, 1986; Werner et al., 1996). Os padrões de resposta para 
produção, encontrados neste experimento permitem classificar as espécies avaliadas na seguinte ordem crescente de tolerância à acidez do solo:

\section{B. mutica $<$ E. Pyramidalis $<$ E. polystachya $<$ B. humidicola}

- Independente da espécie ou do solo, em todas as ocasiões em que a calagem se mostrou benéfica à produção total da parte aérea, tenha o fenômeno, sido explicado por modelos lineares ou quadráticos, em todas as ocasiões $90 \%$ ou mais da produção máxima alcançada pelas forrageiras foi obtida na primeira dosagem de calcário, ou seja, na saturação de $30 \%$ para o solol e $35 \%$ para o solo2. Estes resultados fortificam os já encontrados por vários autores, de que a calagem em muitas forrageiras esta intimamente relacionada ao fornecimento de Ca e Mg como nutriente (Sánchęez, 1976; Werner et al., 1979; Siqueira, 1986; Humpreys, d980, Mitidieri, 1995; Luz et al, 1998; Gonçalves et al., 2000).

Efeitos negativos da calagem que foram verificadas principalmente para a $B$. humidicola em algumas observações também tem sido amplamente relatado na literatura* em estudo de várias outras espécies (Lotero et al., 1971; CIAT, 1987; Humpreys, 1980, Mitidieri, 1995).

A produção de raízes na maioria das observações não foi reduzida pela acidez excessiva do solo, concordando com os resultados obtidos por Goedert et al., 1985; Premazzi, 1991 e Mitidieri, 1995. Tendo é claro assim como ocorrido na parte aérea um comportamento diferenciado entre as espécies, sendo novamente a $B$. humidicola mais tolerante a acidez e a $B$. mutica a mais sensível. E finalmente outro aspecto que deve ser considerado é a relação $\mathrm{Ca} / \mathrm{Mg}$ do solo, que será discutida adiante como fator importante para a nutrição de cálcio pela planta e que possivelmente foi responsável por efeitos no perfilhamento e possivelmente também na produção de materia seca total. 


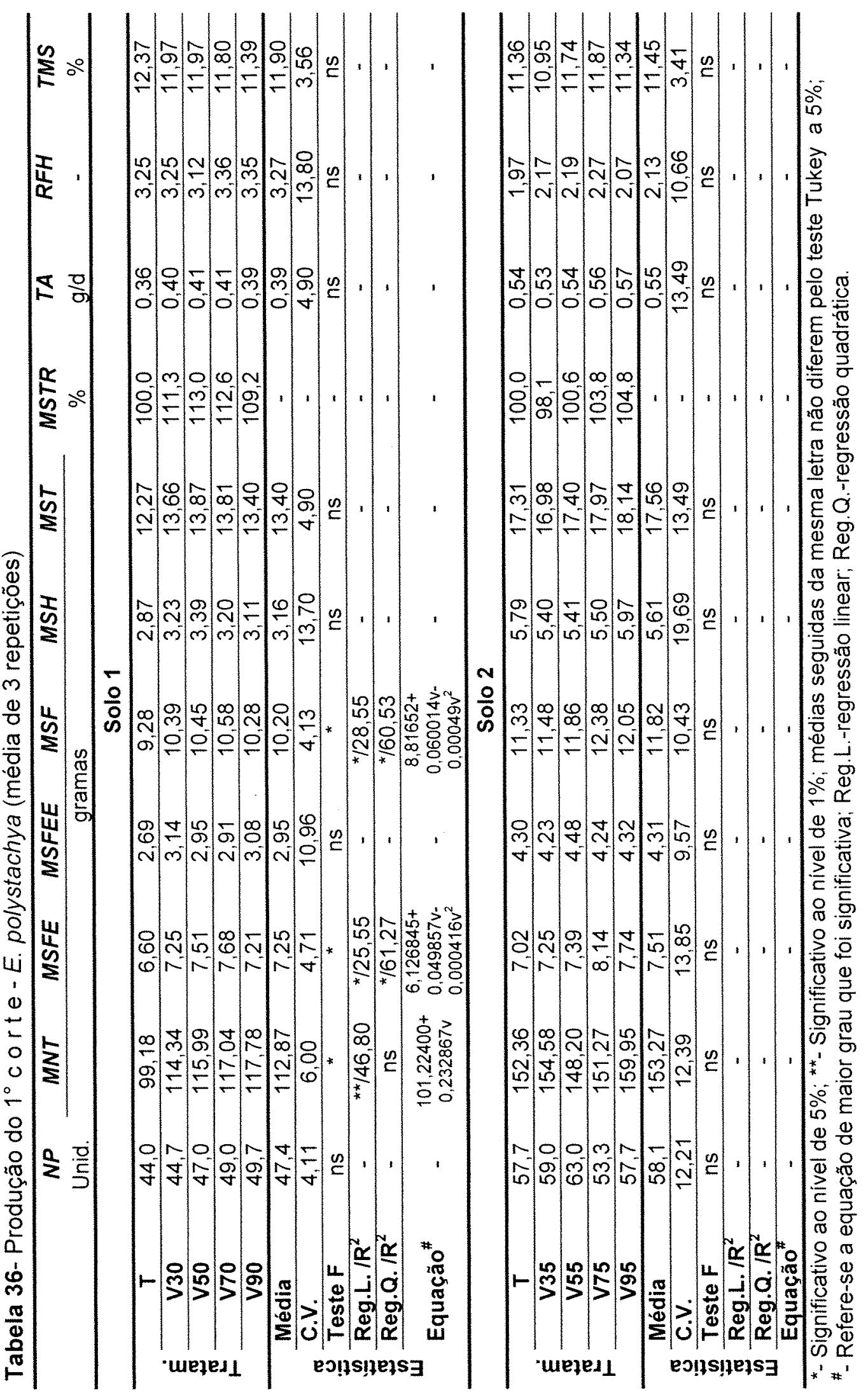




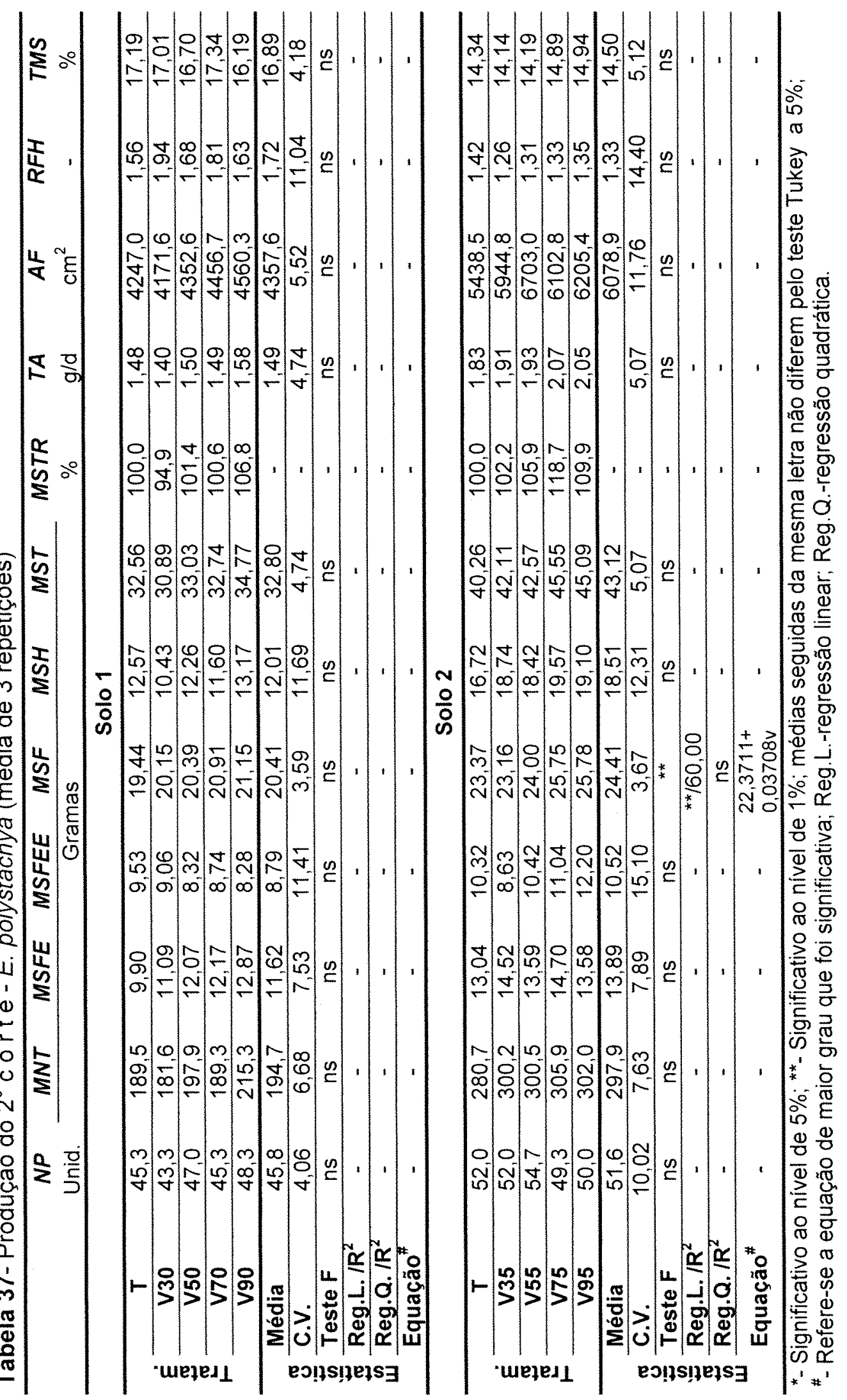




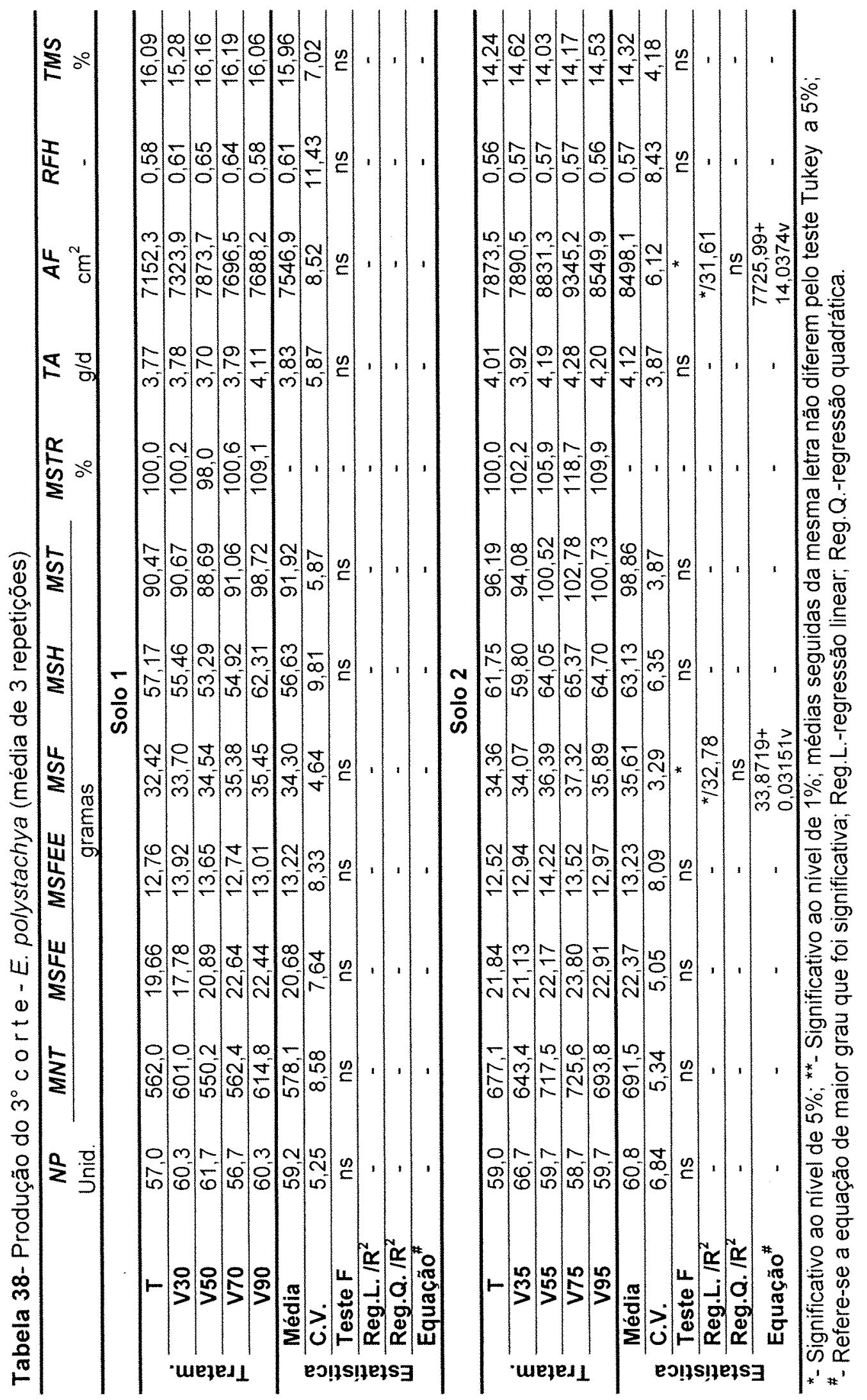




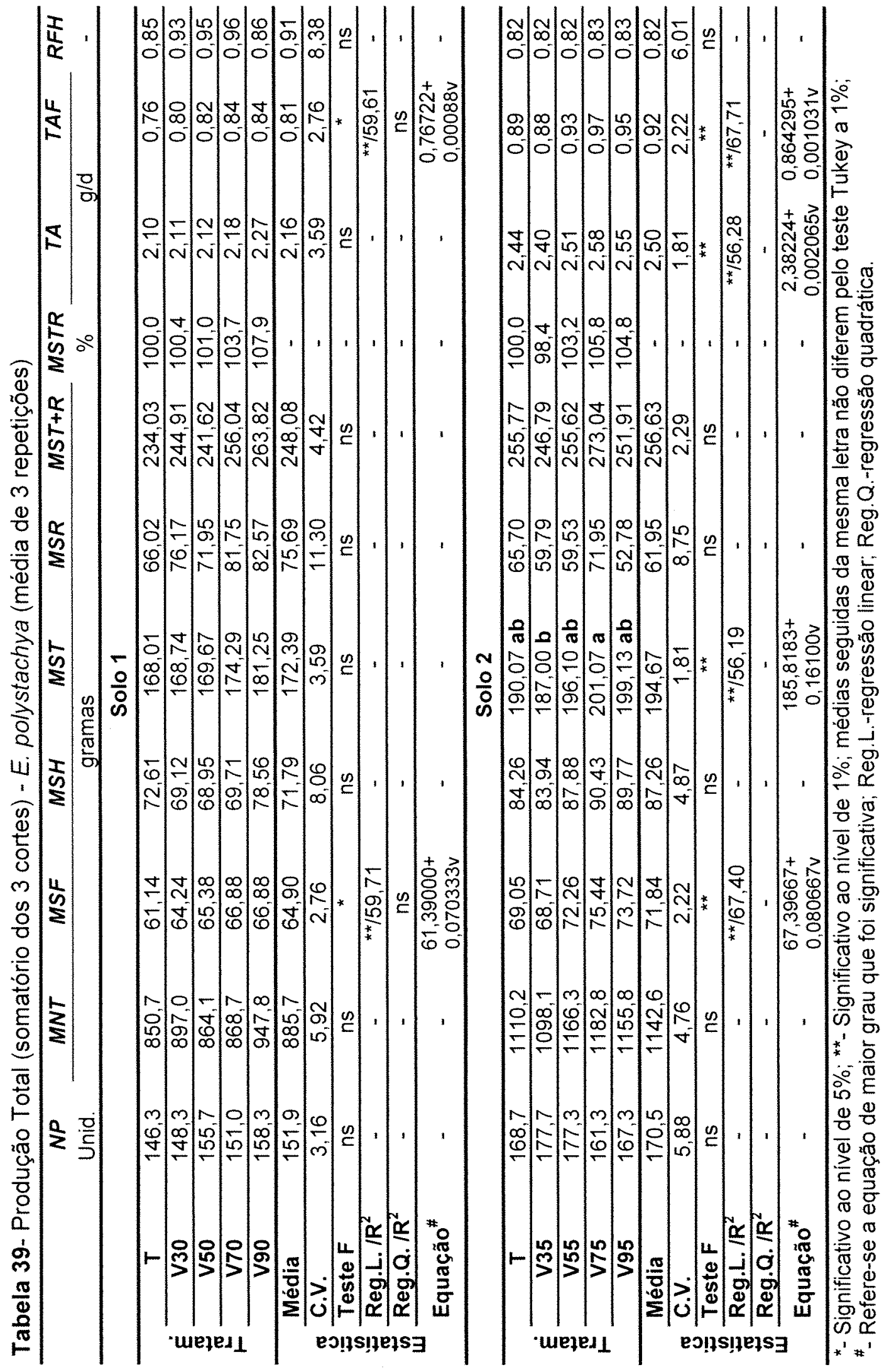




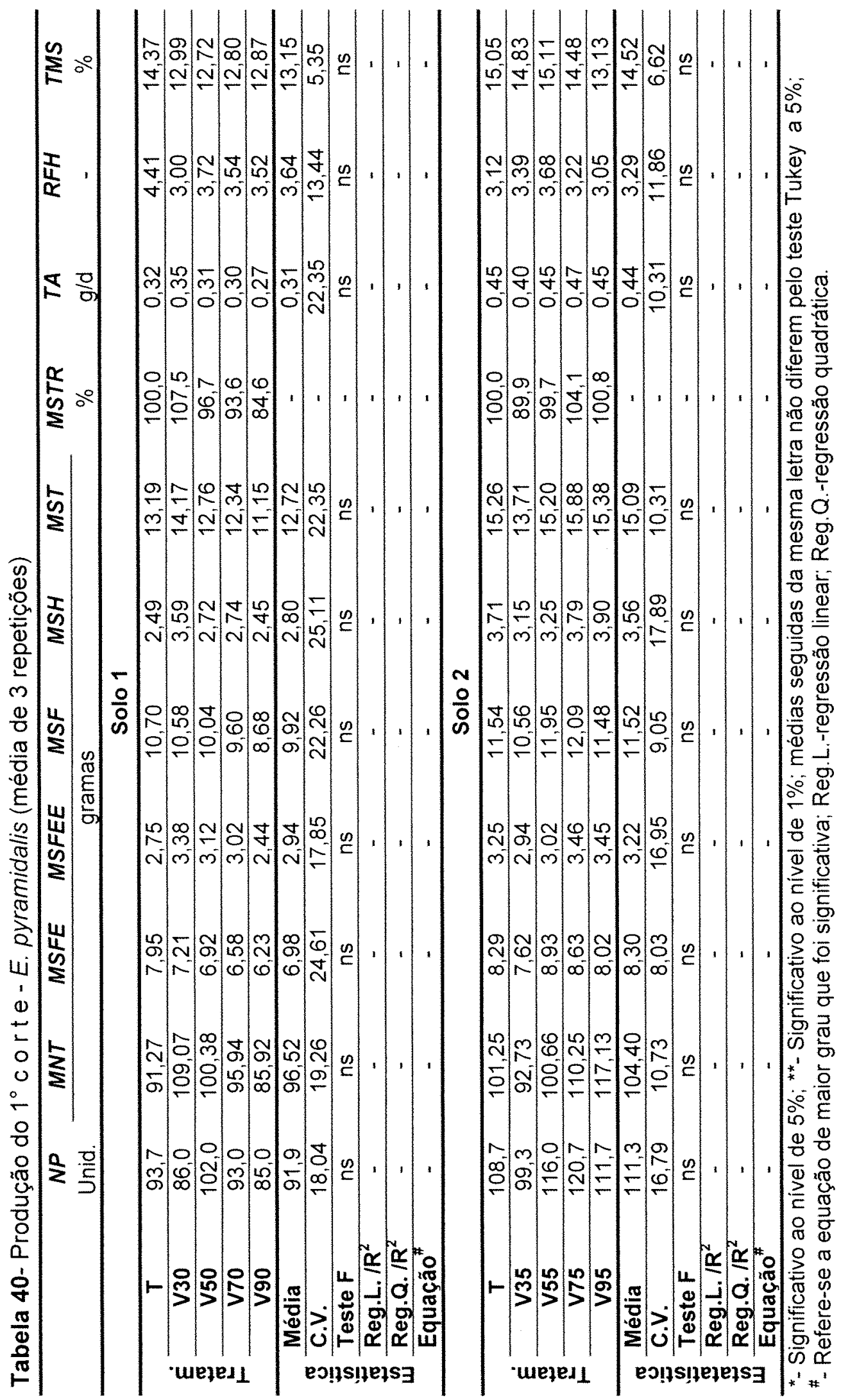




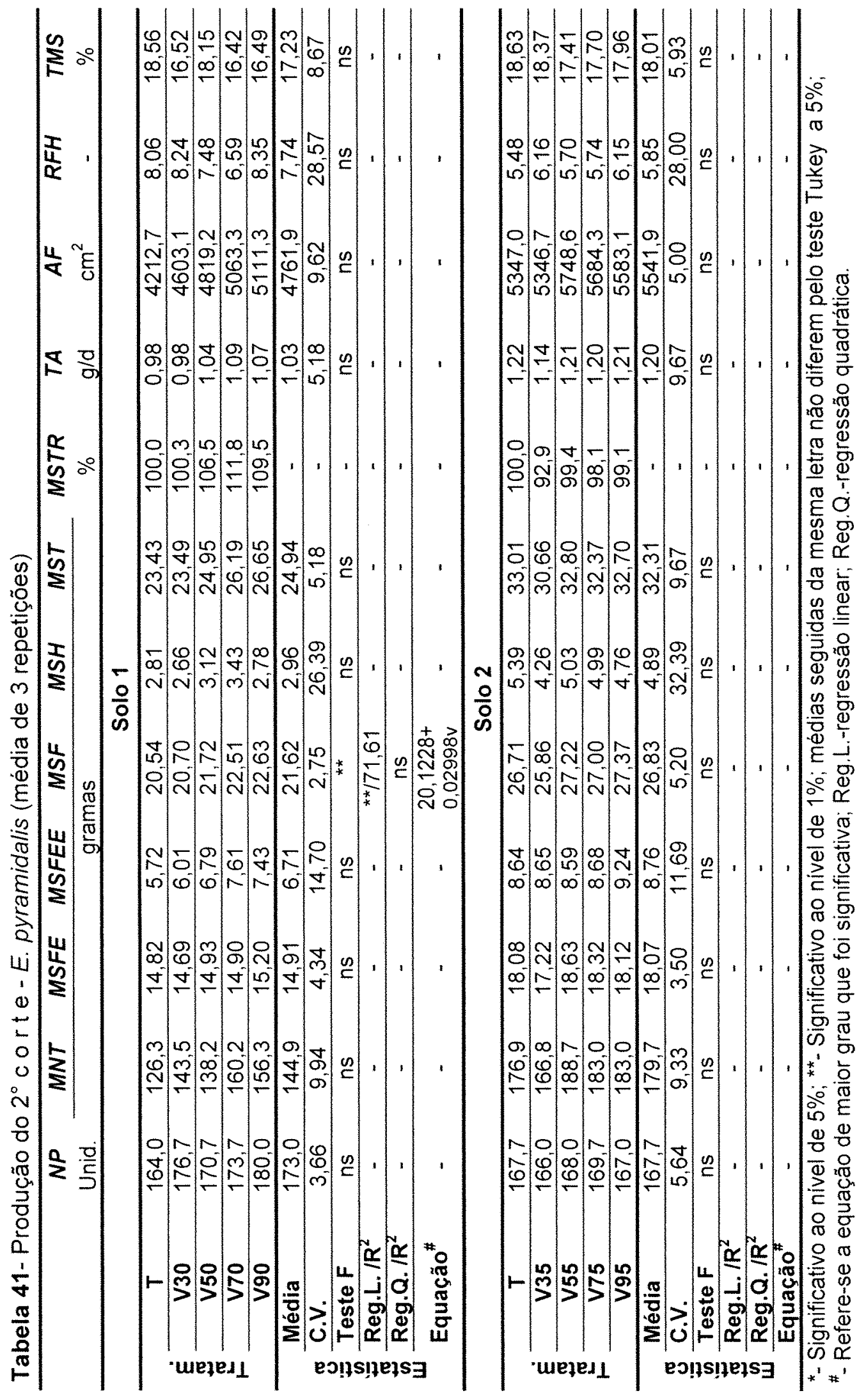



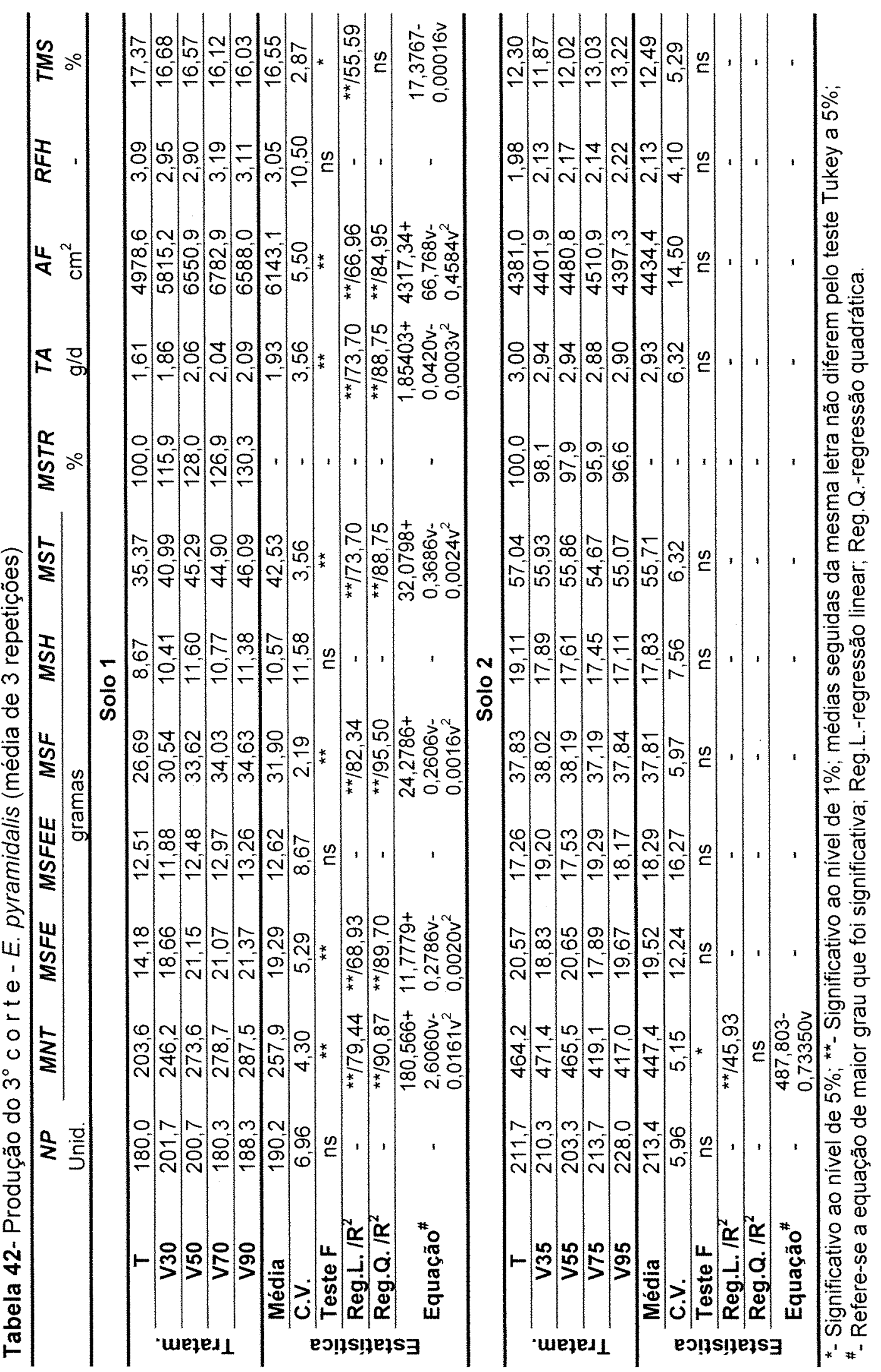


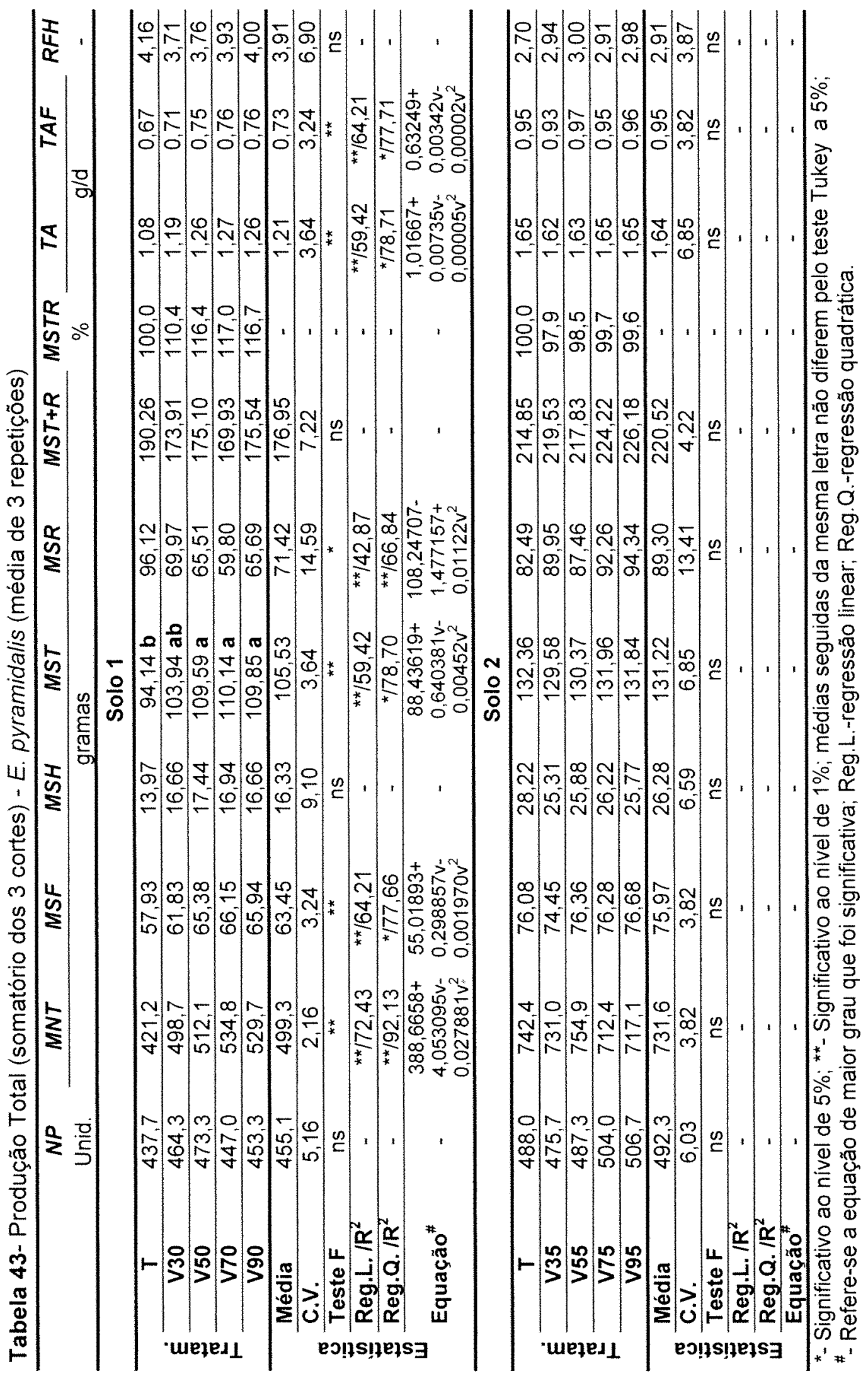




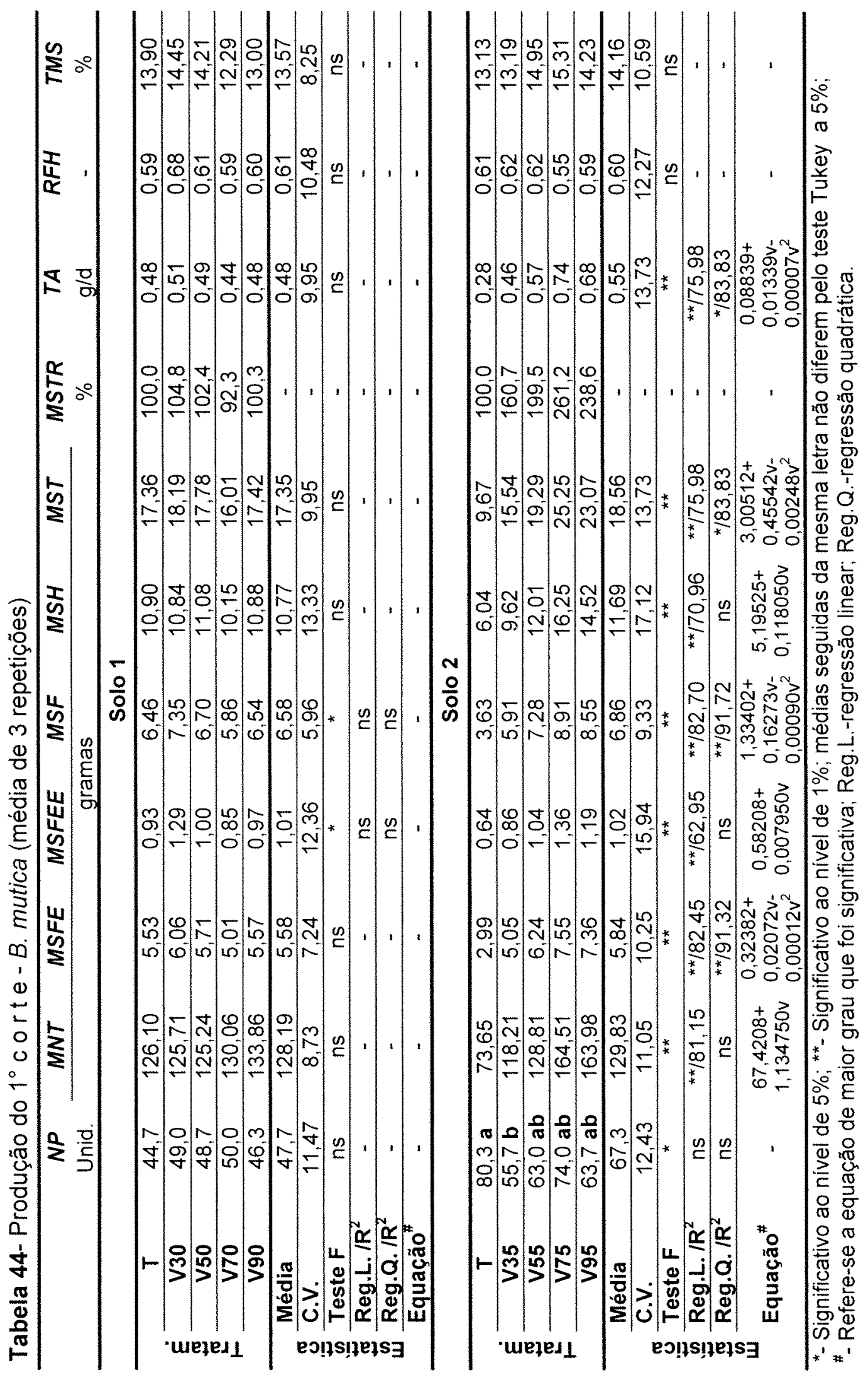




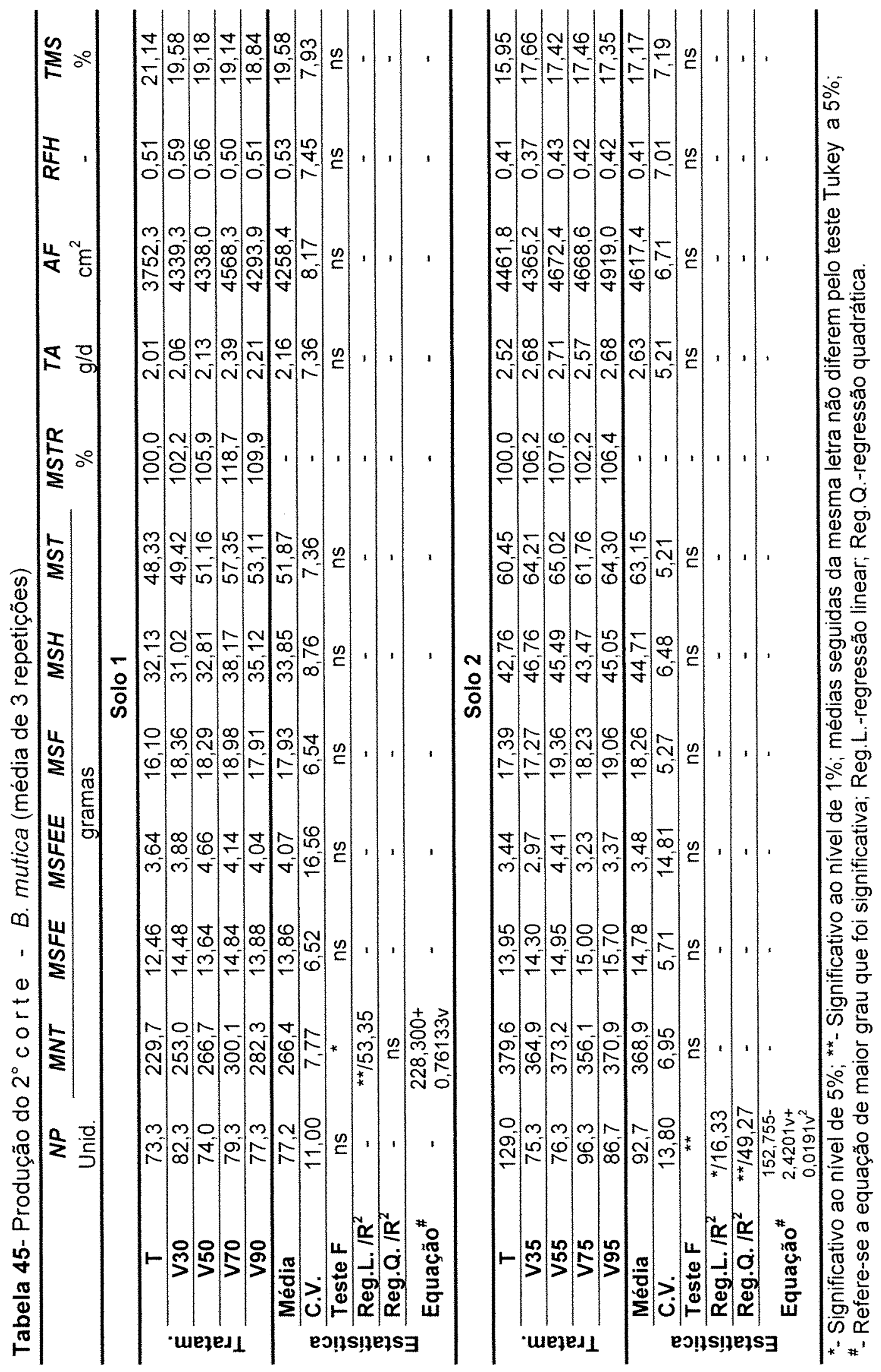




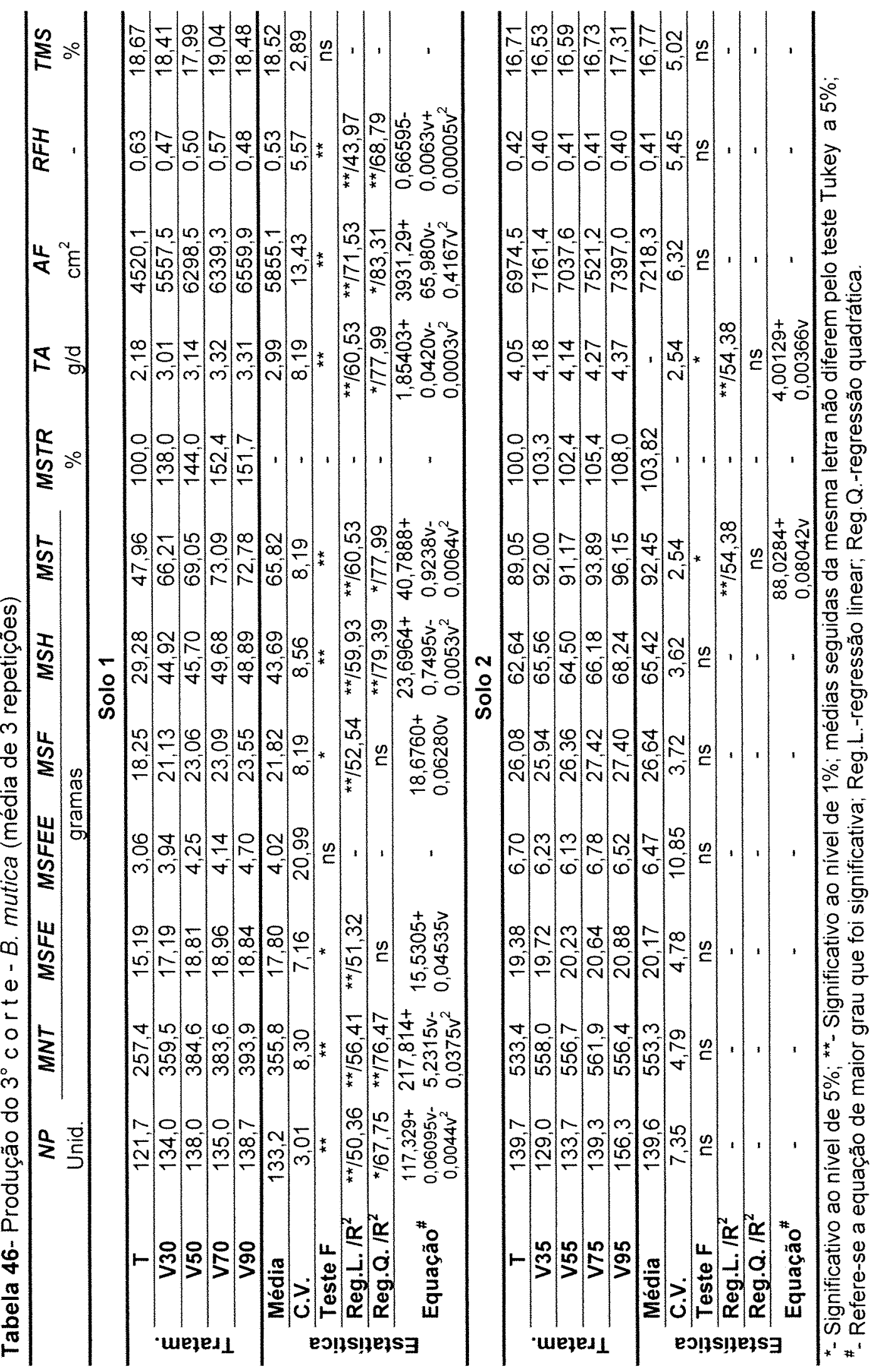




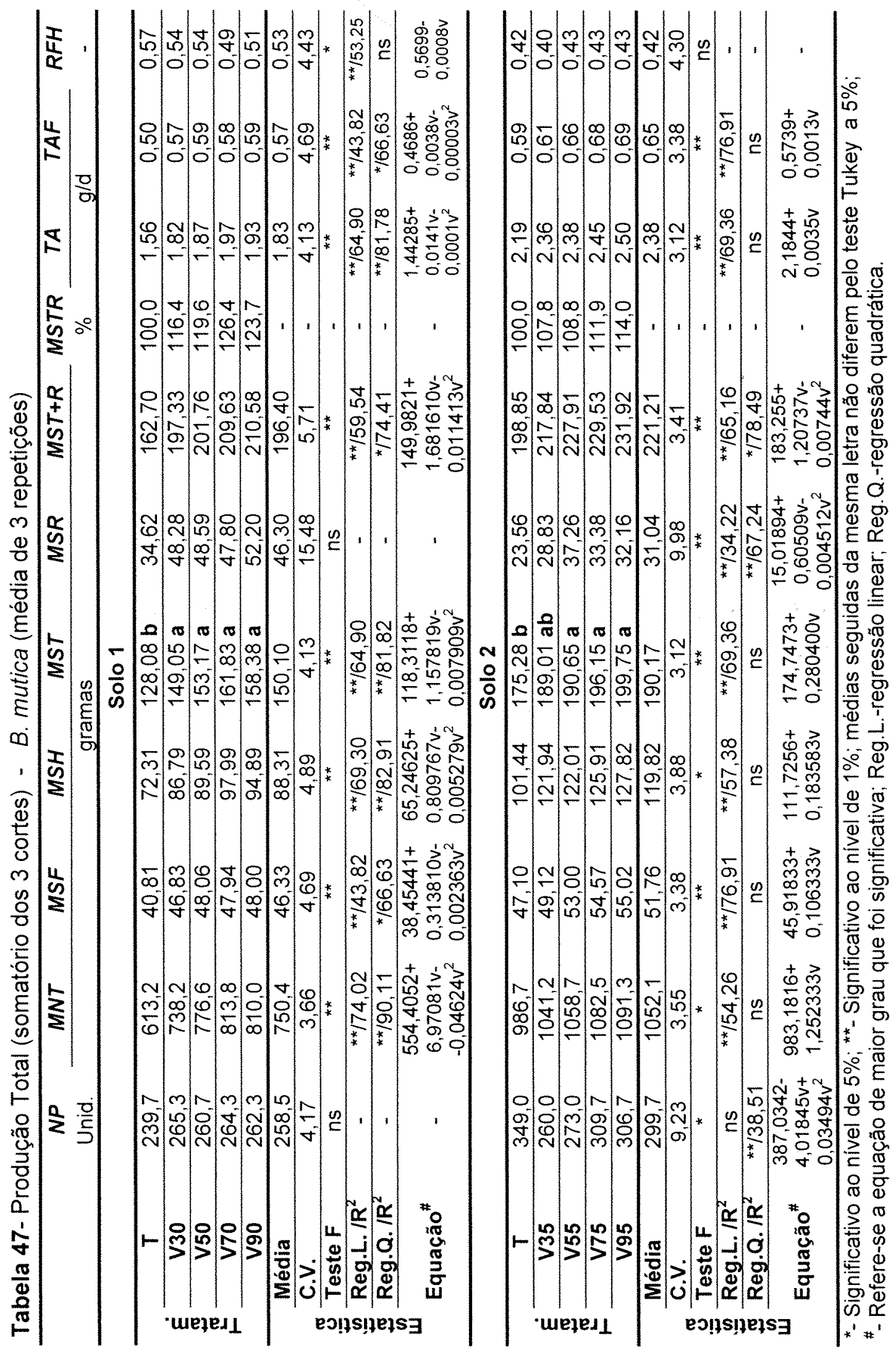




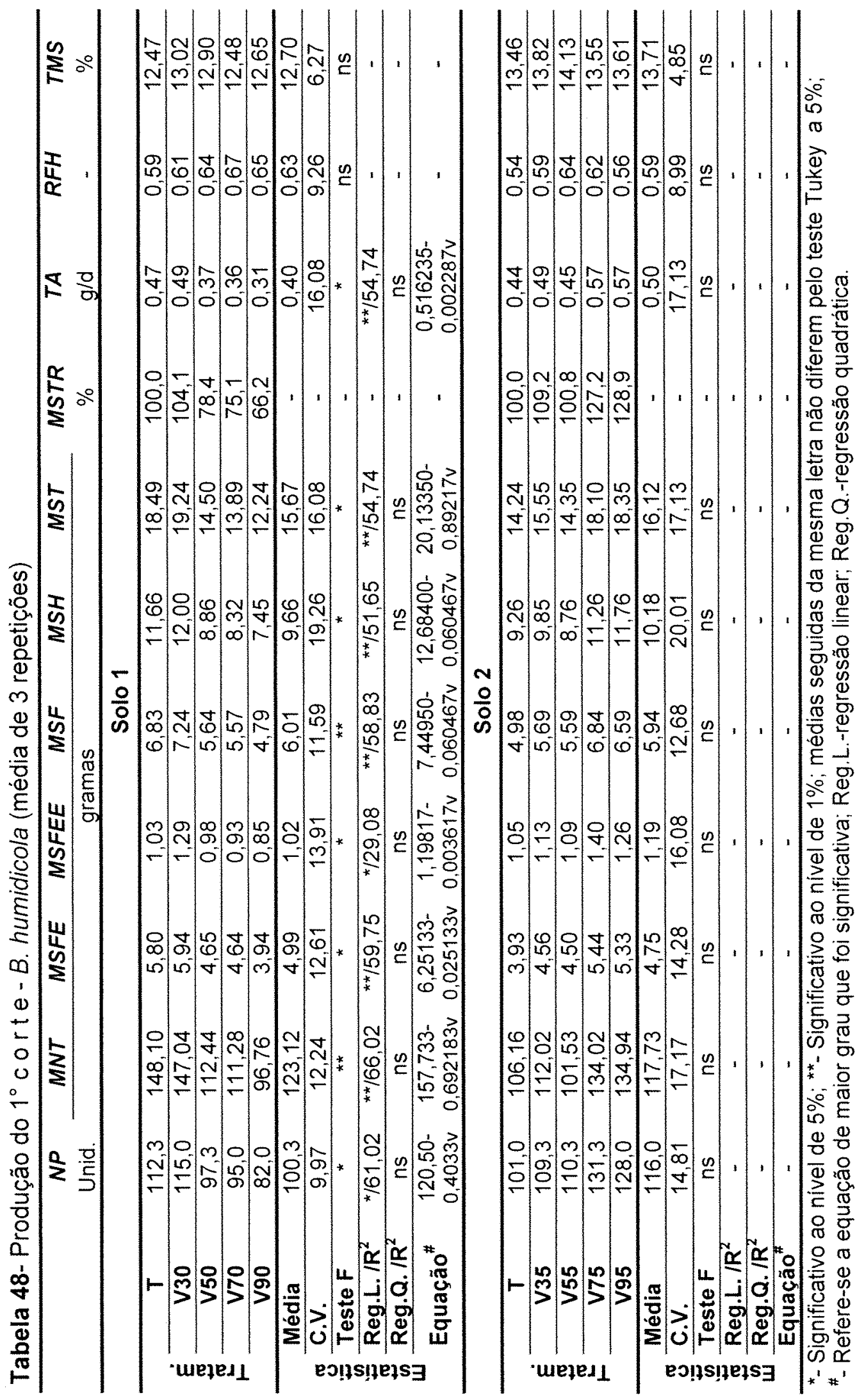




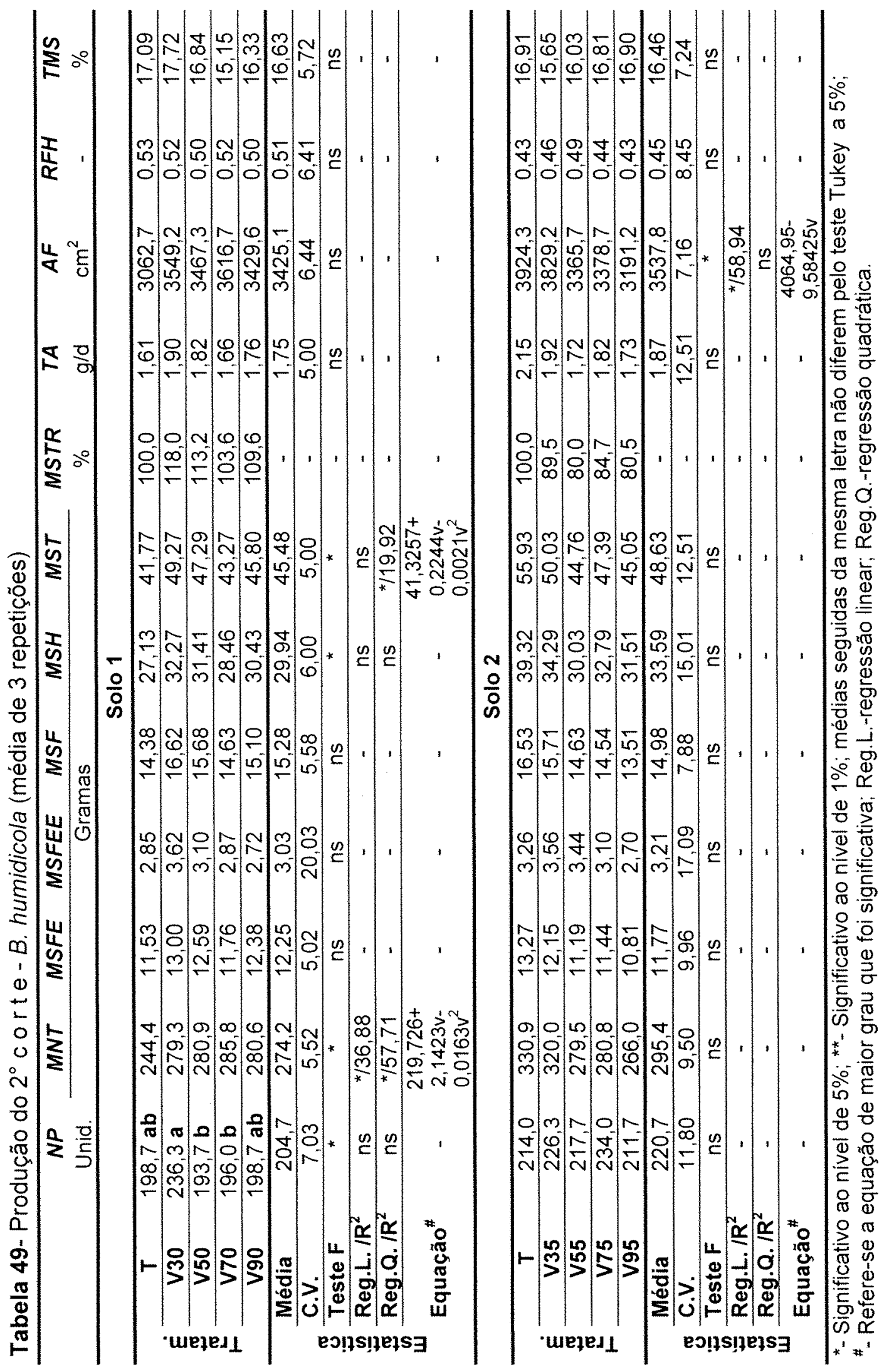




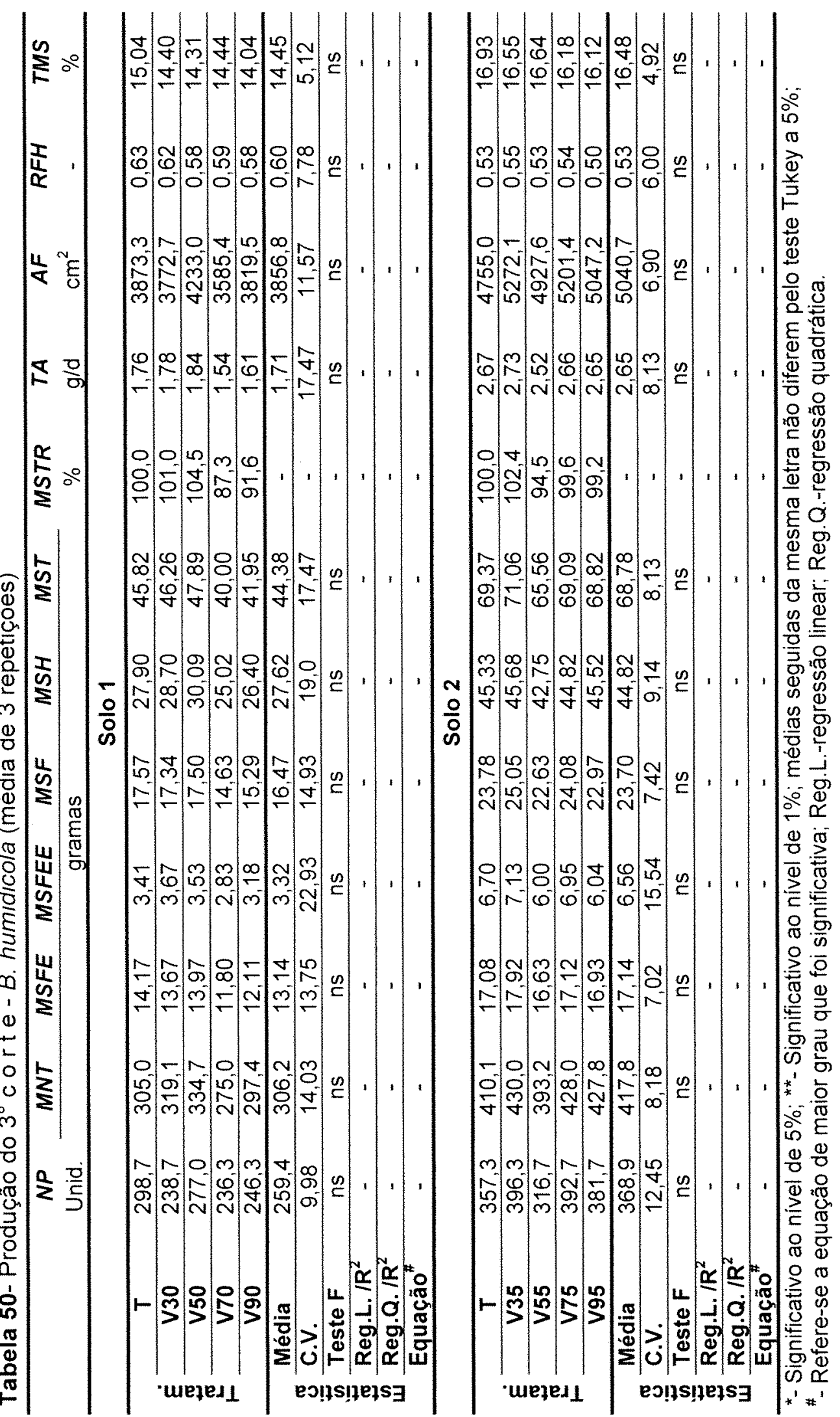




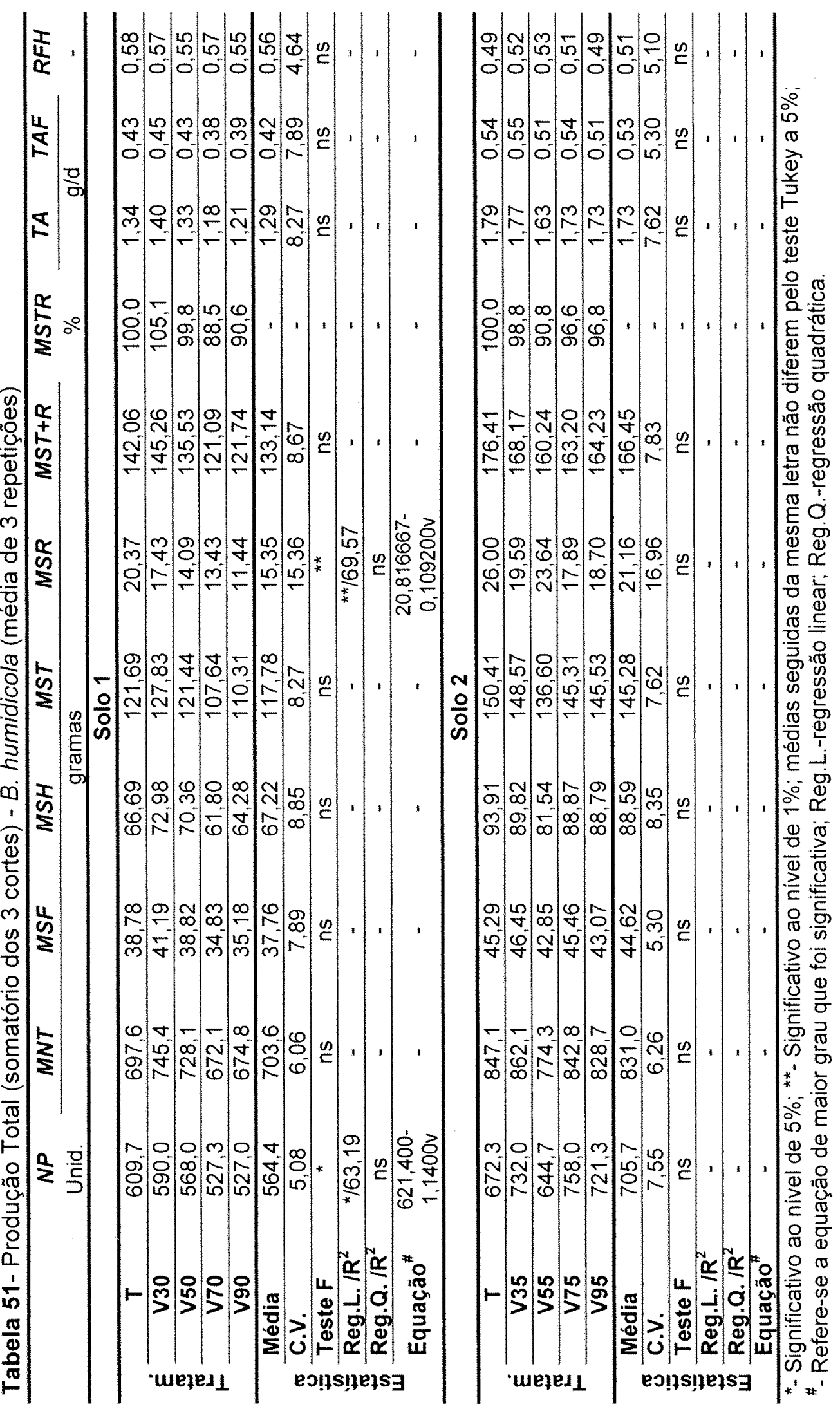




\subsection{COMPOSIÇÃO QUÍMICA DAS FOLHAS}

Os teores encontrados dos macronutrientes ( $\mathrm{P}, \mathrm{K}, \mathrm{Ca}, \mathrm{Mg}, \mathrm{S}$ e $\mathrm{Na}$ ) e micronutrientes $(\mathrm{Cu}, \mathrm{Fe}, \mathrm{Mn}, \mathrm{Zn}$ e B), bem como da relação $\mathrm{Ca} / \mathrm{Mg}$, determinados no tecido foliar das forrageiras, estão apresentados nas Tabelas 52 a 63 . A seguir discutese o comportamento geral para cada elemento. Ao confrontar os resultados aqui obtidos com os encontrados na literatura, optou-se em comparar apenas com resultados obtidos com gramíneas tropicais, sem ficar a toda hora referenciando com qual gramínea o citado autor trabalhou, mas apenas comparando com o modelo de comportamento de cada mineral com os obtidos na literatura. Até mesmo porque, não foi encontrado nenhum trabalho na literatura para as espécies estudadas, que tenha sido avaliado todos estes minerais em função de doses crescentes de calcário.

\subsubsection{FóSFIRD}

O fósforo foi o elemento que teve comportamento mais variável, apresentando efeito significativo em 8 dos 24 cortes realizados (Figuras 73 e 74), ou seja, na maioria das observações não houve efeito da calagem para os teores de $\mathrm{P}$ nas forrageiras, o que está de acordo com o encontrado por Abruña et al.(1964), Werner et al.(1979), Premazzi (1991), Colozza (1993), Mitidieri (1995). Para a E. polystachya não foi verificado em nenhuma oportunidade efeito significativo para ambos os solos. Para a E. pyramidalis em duas ocasiões o efeito no teor de $\mathrm{P}$ foi explicado por curvas quadráticas com ponto de mínimo próximo a primeira dose de calcário, crescendo suavemente até a última dose. A B. mutica teve os teores de $\mathrm{P}$ alterados em 3 oportunidades pela calagem, mostrando de forma geral diminuição dos teores. A $B$. humidicola teve comportamento inverso a sua companheira de gênero, ou seja, tendo os teores de $\mathrm{P}$ aumentados linearmente com a calagem em 3 oportunidades. $\mathrm{O}$ comportamento dos teores de $\mathrm{P}$ quando significativo para as espécies do gênero Brachiaria, tiveram comportamento na 
maioria das vezes inverso ao ocorrido com a MSF, revelando possível efeito concentração e diluição do fósforo para produções menores e maiores respectivamente.

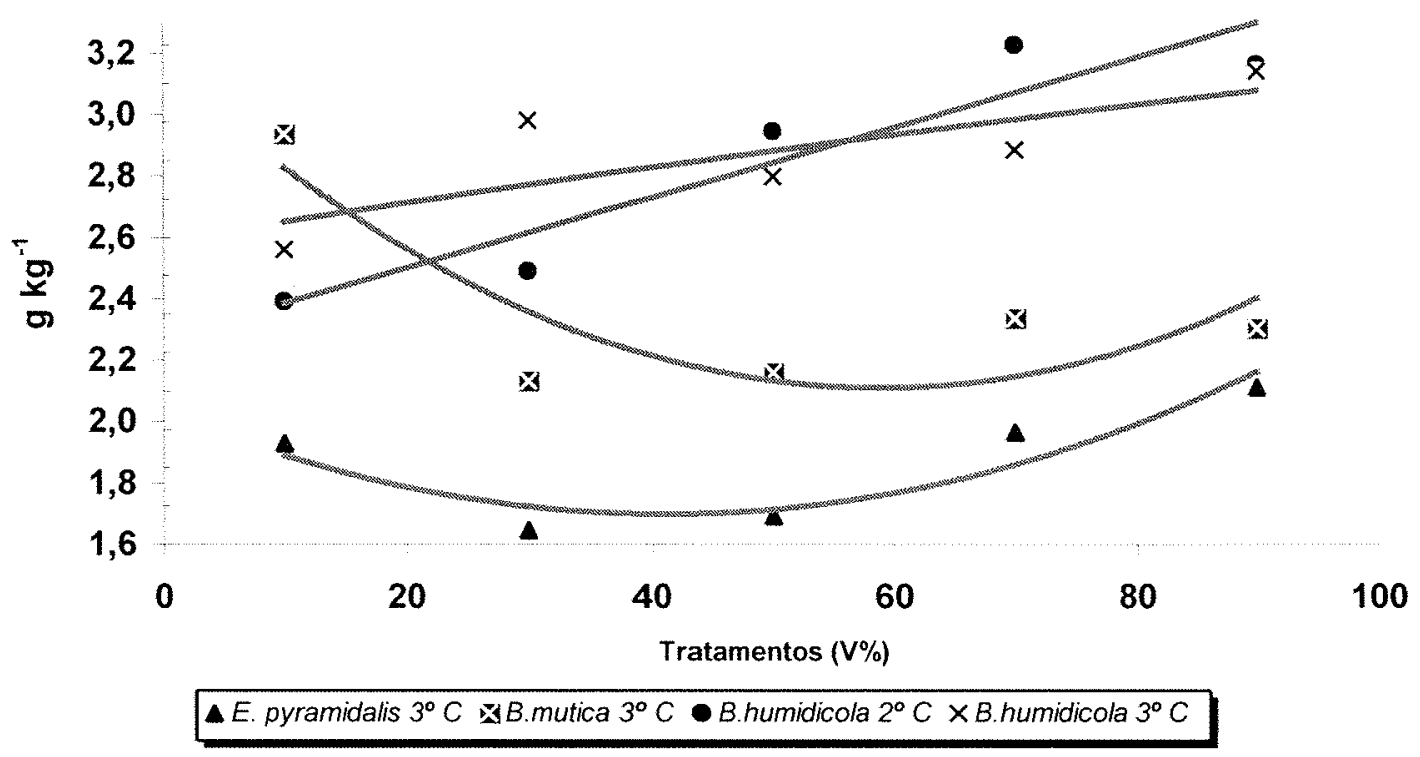

Figura 73- Teores de fósforo nas folhas das forrageiras, quando cultivadas no solo 1.

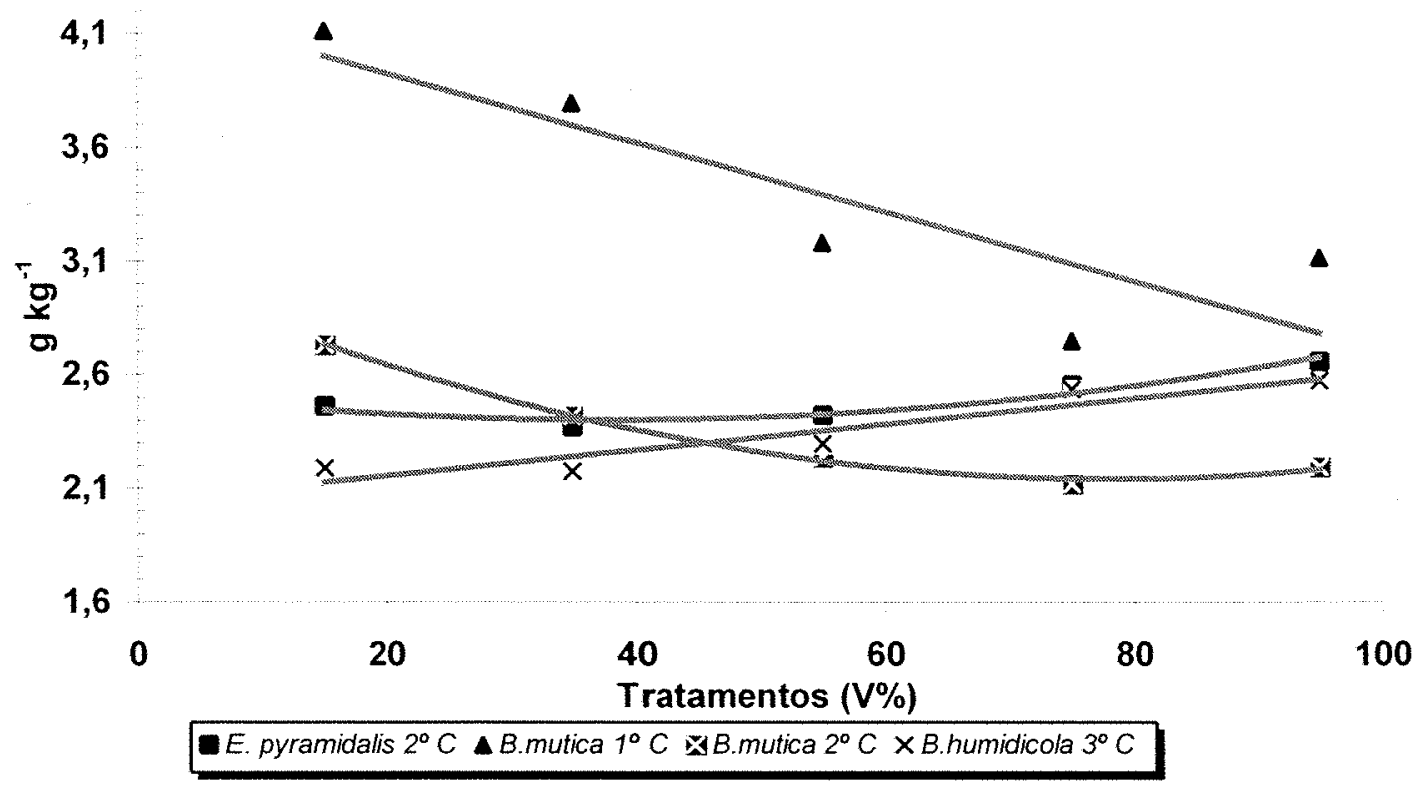

Figura 74- Teores de fósforo nas folhas das forrageiras, quando cultivadas no solo 2. 


\subsubsection{PDTÁsSID}

Os teores de potássio nas folhas não foram significativamente alterados em 17 dos 24 cortes realizados, e nos 7 casos em que foi significativamente afetado, este mostrou declínio dos teores em relação às doses crescentes de calcário aplicadas ao solo (Figuras 75 e 76). Este declínio dos teores de K, com o aumento da dose de calcário, pode ser explicado pela competição com outros cátions introduzidos no sistema pela calagem ( $\mathrm{Ca}$ e $\mathrm{Mg}$ ). Os teores médios totais de potássio na folhas das forrageiras cultivadas no solol sempre foram em média maiores que no solo2, o que reforça a hipótese de competição, já que o solo2 possui maiores valores absolutos de outras bases (Ca, Mg e Na). Este efeito na redução do K foi também verificado por Premazzi (1991) e apenas como tendência por Werner et al.(1979). Pelos resultados obtidos por Silva (1992) avaliando a interação Ca, K e Na para a nutrição de duas forrageiras, esta competição do $\mathrm{K}$ parece estar mais ligada ao $\mathrm{Mg}$ e ao $\mathrm{Ca}$ do que ao $\mathrm{Na}$, já que esta autora não verificou interação K e Na. Malavota (1980) afirma que a interação Ca versus Mg apresenta uma inibição competitiva na região da membrana plasmática.

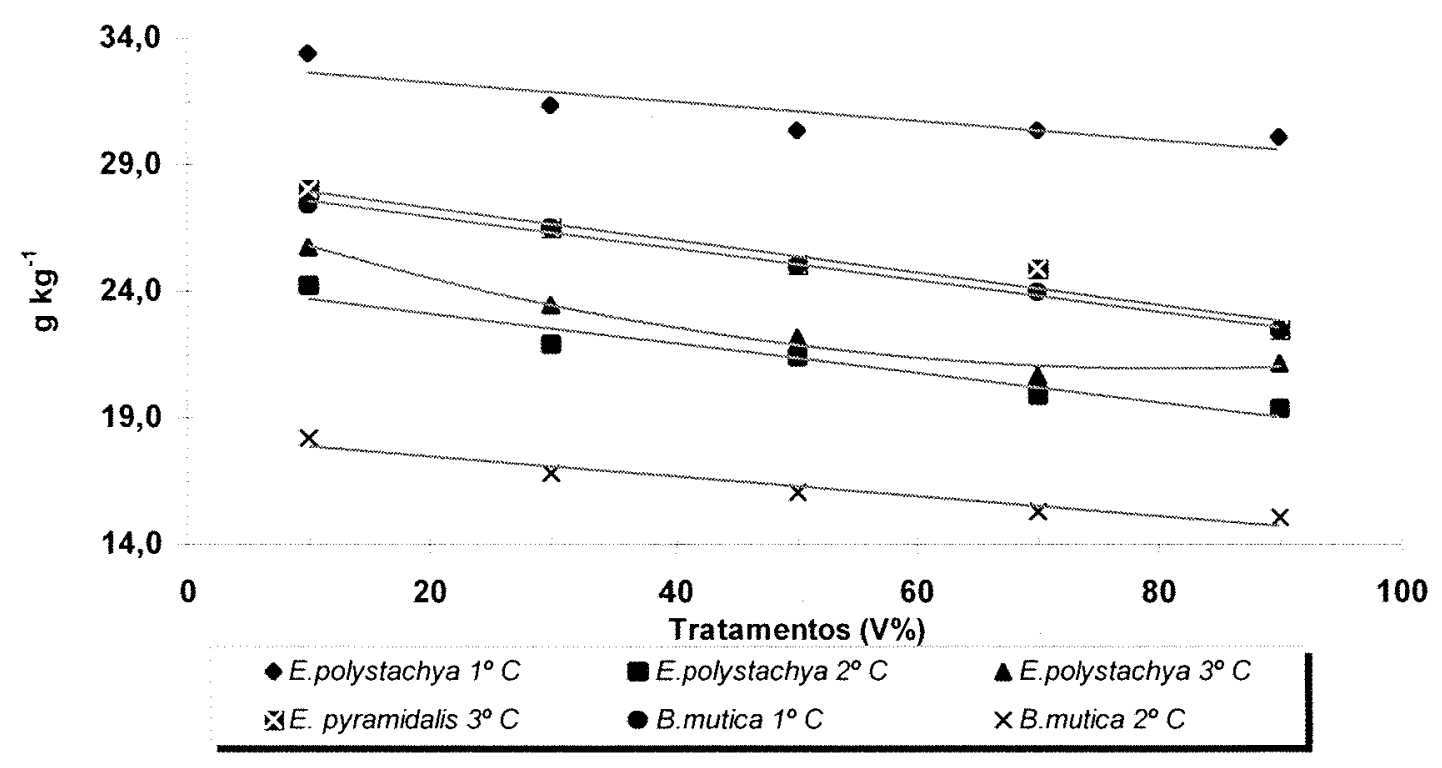

Figura 75- Teores de potássio nas folhas das forrageiras, quando cultivadas no solo 1. 


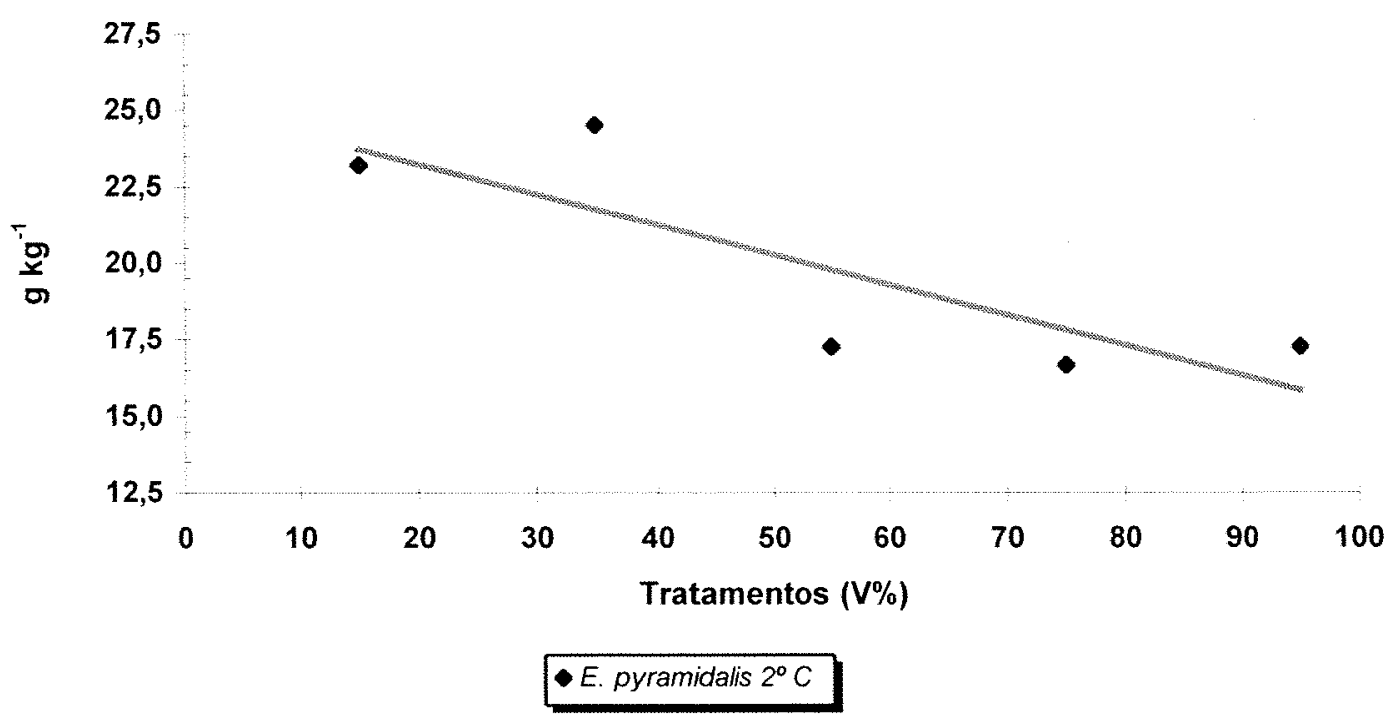

Figura 76- Teores de potássio nas folhas das forrageiras, quando cultivadas no solo 2.

\subsubsection{CÁlCII}

Os teores de cálcio na folhas, em todos os cortes, para qualquer uma das forrageiras avaliadas e em ambos os solos cultivados, foram sempre significativamente afetados pelas doses crescentes de calcário. Fenômeno explicado, na maioria das vezes, por funções quadráticas, com pontos de máxima (Figuras 82 e 83), e em alguns cortes por modelos lineares crescentes (resultados que estão de acordo com os obtidos por Abruña et al.,1964; Werner et al., 1979; Gomide et al., 1986; Carriel et al.,1989; Premazzi, 1991; Colozza, 1993; Mitidieri,1995 e Gonçalves et al. 2000).

Assim como ocorrido com o potássio, os teores de cálcio das folhas das forrageiras cultivadas no solol sempre foram maiores do que para as cultivadas no solo2, apesar deste solo sempre apresentar maiores concentrações de cálcio e ambos terem valores aproximados de K. Mostrando mais uma vez a competição entre bases, neste caso mais especificamente entre $\mathrm{Ca}$ e $\mathrm{Mg}$, já que o solo 2 sempre mostrou maiores teores de $\mathrm{Mg}$ e menores relações $\mathrm{Ca}: \mathrm{Mg}$. 
Foram verificados durante a condução do experimento sintomas de deficiência de cálcio. As espécies do gênero Brachiaria foram as mais afetadas, porém com bem maior intensidade para a espécie $B$. mutica. Os sintomas foram verificas em várias intensidades desde rachaduras nos bordos das lâminas foliares mais novas, passando por necroses parciais da folhas mais jovens até necrose total com morte do meristema apical (Figuras 77 a 80). A intensidade dos sintomas foi mais freqüente nos dois primeiros períodos de crescimento para a $B$. mutica e somente no primeiro período para a $B$. humidicola, sendo que os sintomas praticamente desapareceram no último período. A maior incidência ocorreu no solo2 nas primeiras doses de calcário. Estes sintomas parecem estar muito mais relacionados com a relação $\mathrm{Ca} / \mathrm{Mg}$ do que simplesmente com o teor absoluto de Ca. Como será discutido no item relação $\mathrm{Ca} / \mathrm{Mg}$ o solo2 sempre possuiu mais $\mathrm{Ca}$ que o solo1 porém também menores relações $\mathrm{Ca} / \mathrm{Mg}$, contudo esta relação foi aumentado ao longo dos cortes o que possibilitou uma melhor nutrição de Ca pela planta, com desaparecimento quase total dos sintomas de deficiência no último corte, mesmo com os teores de cálcio diminuído no solo.

Outro possível sintoma de deficiência de cálcio está relacionado ao mecanismo de fechamento estomático em resposta a condições ambientais (Karp, 1996). Pois a espécie E. pyramidalis na última semana de crescimento antes do terceiro corte mostrouse murcha nas horas mais quentes do dia para o tratamento testemunha, quando cultivada no solol(Figura 81). Com menor intensidade este fenômeno também foi verificado para as espécies B. mutica e E. polystachya. Porém este sintoma de murchamento só interferiu significativamente, como visto no item sobre produção, no teor de matéria seca da E. pyramidalis. O efeito no teor de matéria seca provavelmente não foi detectado nas outras espécies devido ao procedimento no dia do corte, ou seja, por volta de 6:00 h todos os vasos que seriam cortados naquele dia eram retirados da casa de vegetação e levados para dentro do laboratório, onde eram cortados. Neste horário as plantas não apresentavam o sintoma de murchamento. Sendo detectado então somente na espécie E. pyramidalis aonde este fenômeno ocorreu com mais intensidade. Não se descarta porém que este sintoma de murchamento possa ter sido causado por uma possivel toxidez de elementos como o $\mathrm{Al}$ ou $\mathrm{Mn}$, já que as parcelas testemunhas ao 
final do último corte se encontravam extremamente acidificadas com pH próximo 3,5, ou seja, não podendo-se isolar a causa deste efeito apenas como deficiência de cálcio, mais sim causada possivelmente por uma combinação de fatores.

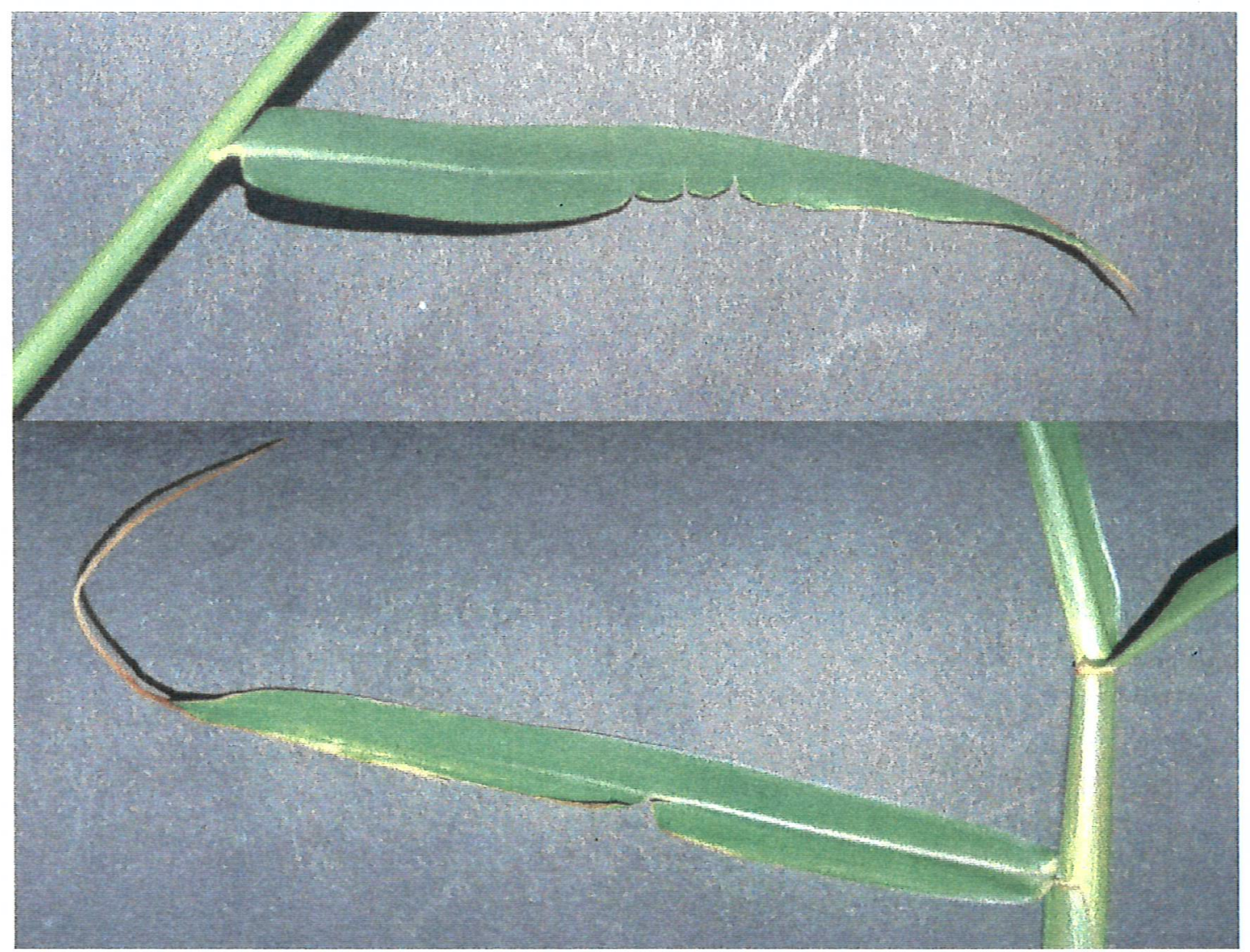

Figura 77- Sintoma de deficiência de $\mathrm{Ca}$, caracterizado por rachaduras nos borados das folhas novas da $B$ muitca.
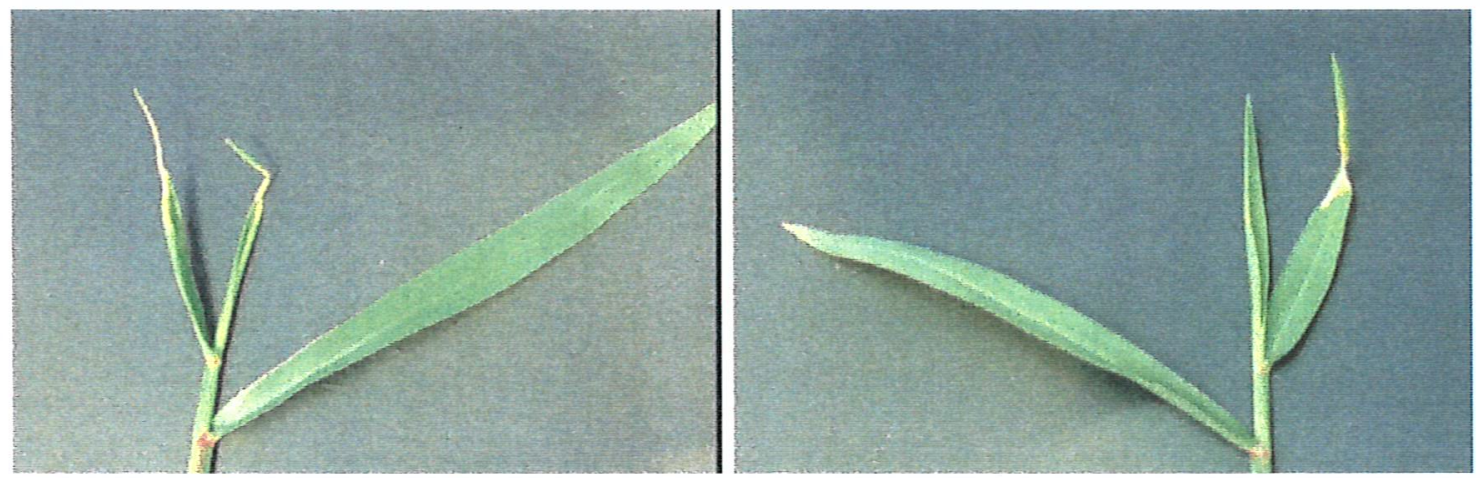

Figura 78- Sintoma de deficiência de $\mathrm{Ca}$, caracterizado por rachaduras nos borados das folhas novas da $B$. humidicola. 


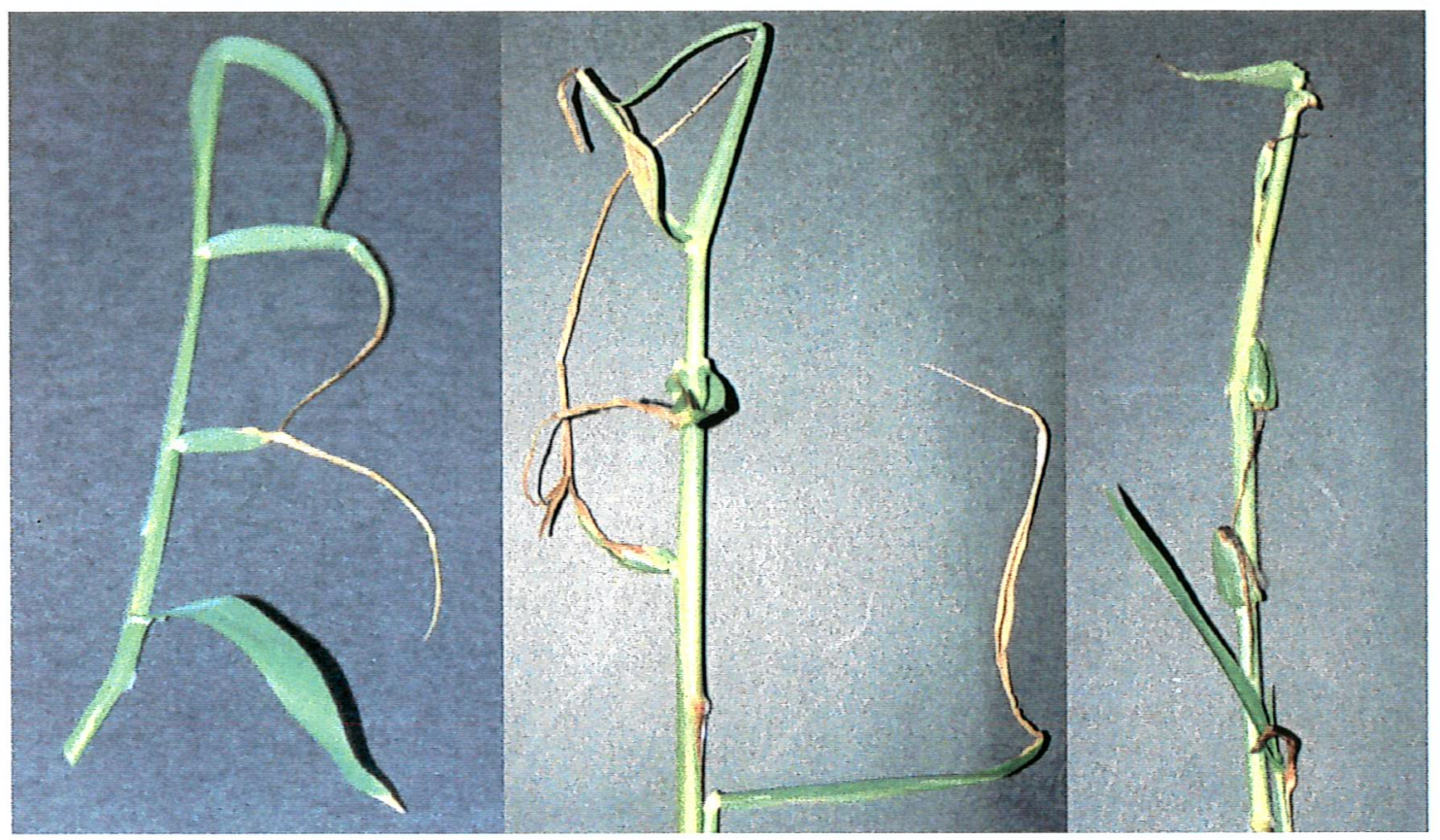

Figura 79- Sintoma de deficiência de $\mathrm{Ca}$, caracterizado por necrose parcial a total das folhas mais novas da $B$ muitca.

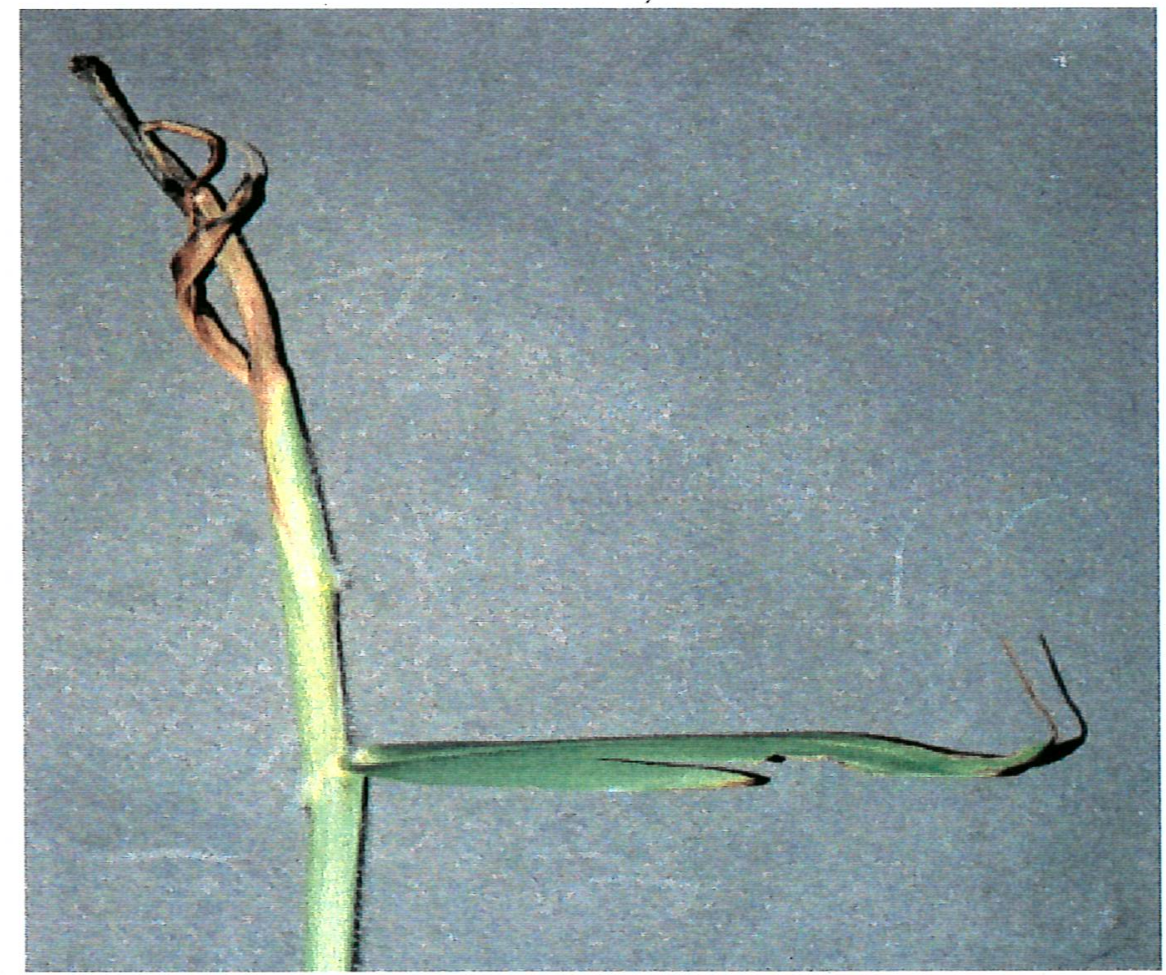

Figura 80- Sintoma de deficiência de $\mathrm{Ca}$, na sua forma mais severa caracterizando morte do meristema apical da $B$. mutica. 


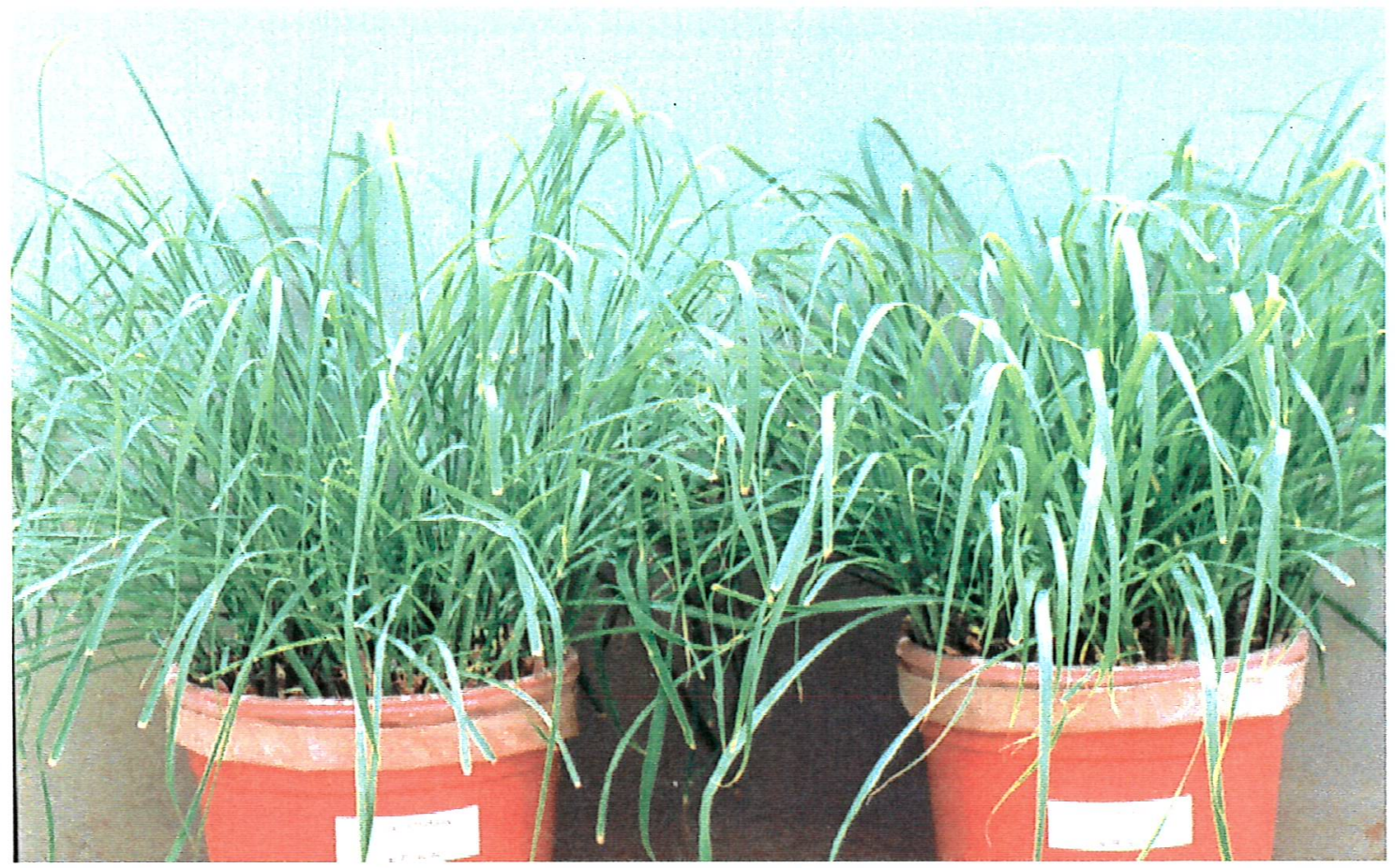

Figura 81- Possível deficiência de Ca na espécie E. pyramidalis, causando murchamento das folhas das parcelas testemunha por volta do meio dia. À esquerada temos um vaso da parcela testemunha, sem calagem (V10) e à direta um vaso na dose máxima de calcário (V90) cultivadas no solo1. Foto tirada poucos dias antes do terceiro e último corte realizado

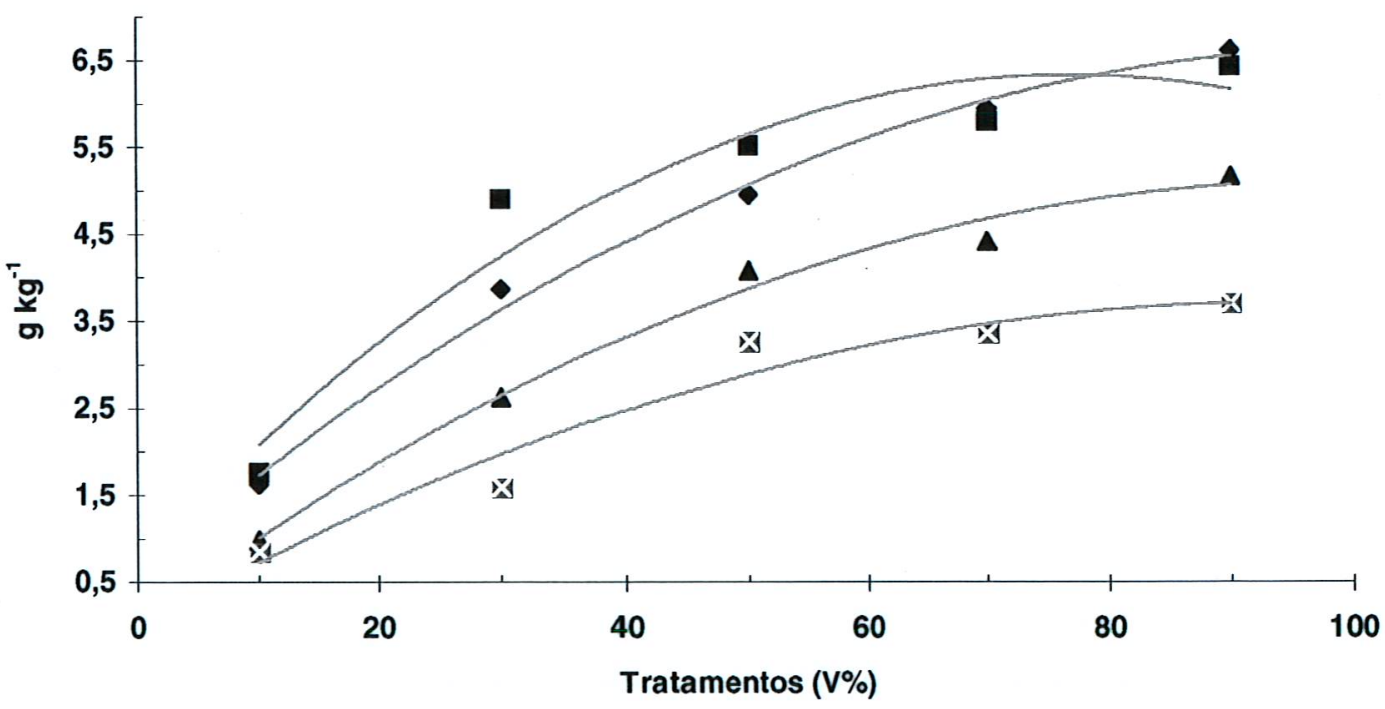

E.polystachya $1^{\circ} \mathrm{C}$ E. pyramidalis $3^{\circ} \mathrm{C} \Delta$ B.mutica $1^{\circ} \mathrm{C}$ ⿶B.humidicola $1^{\circ} \mathrm{C}$

Figura 82- Teores de cálcio nas folhas das forrageiras, quando cultivadas no solo 1. 


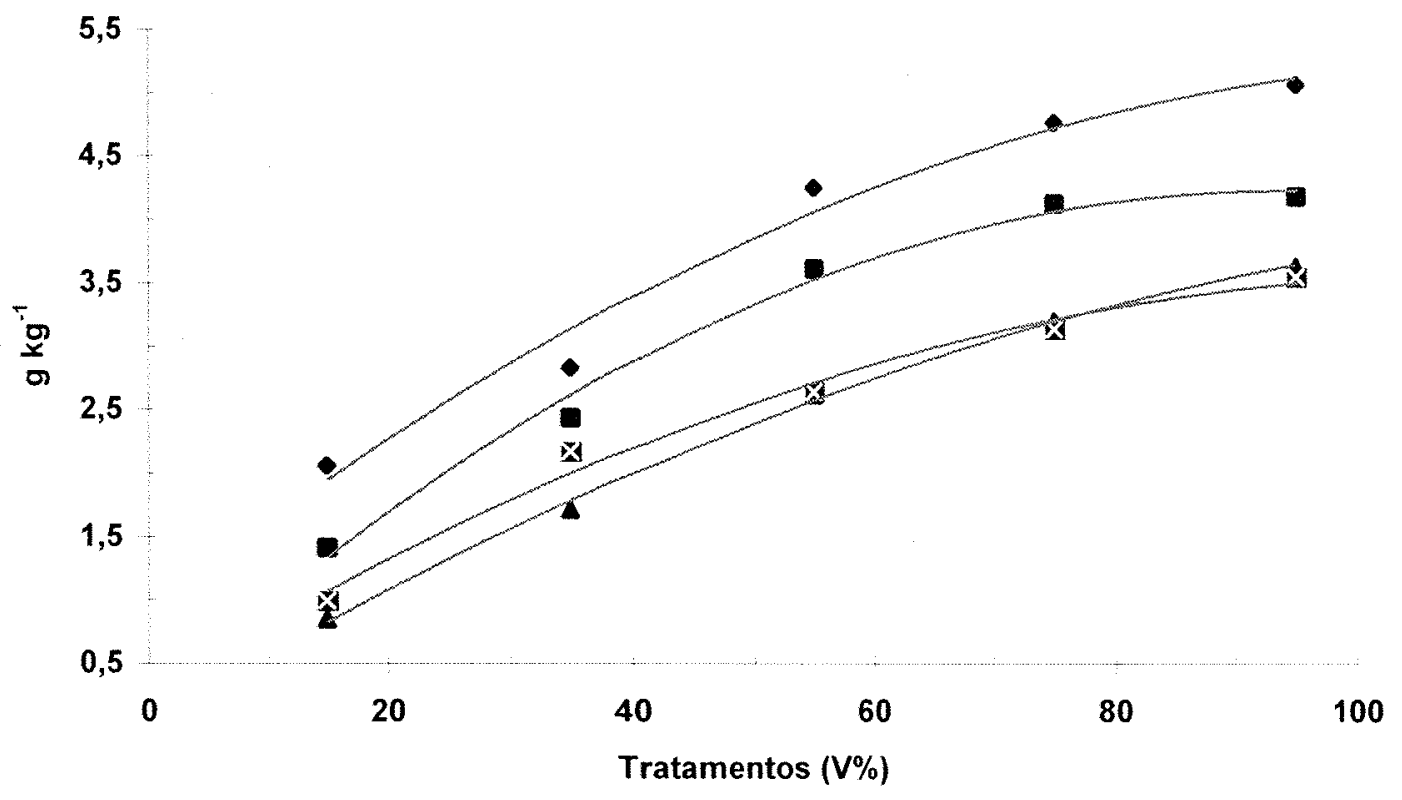

- E.polystachya $2^{\circ} \mathrm{C} \mathbf{E}$. pyramidalis $1^{\circ} \mathrm{C} \triangle$ B.mutica $2^{\circ} \mathrm{C} \bowtie$ B.humidicola $2^{\circ} \mathrm{C}$

Figura 83- Teores de cálcio nas folhas das forrageiras, quando cultivadas no solo 2.

\subsubsection{MAgNÉSIO}

Os teores de magnésio tiveram comportamento estatístico bem semelhante ao ocorrido com o cálcio, ou seja, tendo seus valores acrescidos pela calagem (Figuras 84 e 85), resultados estes também encontradas por Gomide et al. (1986), Carriel et al.(1989), Premazzi (1991), Colozza (1993), Mitidieri (1995) e Gonçalves et al. (2000). Porém em duas oportunidades ( $1^{\circ}$ e $2^{\circ}$ corte da $E$. polystachya cultivada no solo 2$)$ os teores de $\mathrm{Mg}$ não foram afetados significativamente, possivelmente justificado pela quantidade natural de $\mathrm{Mg}$ já encontrada neste solo, possibilitando a planta extrair o máximo de magnésio possível nas primeiras doses de calcário aplicada, não se beneficiando de maiores concentrações de Mg no solo. Porém, ao contrário dos teores de cálcio que estavam em maior concentrações nas folhas das forrageiras cultivadas no solo1, as plantas cultivadas no solo 2 sempre possuíram maiores concentrações de magnésio, sendo um reflexo direto da maior concentração de $\mathrm{Mg}$ no solo, bem como da menor relação Ca:Mg. 


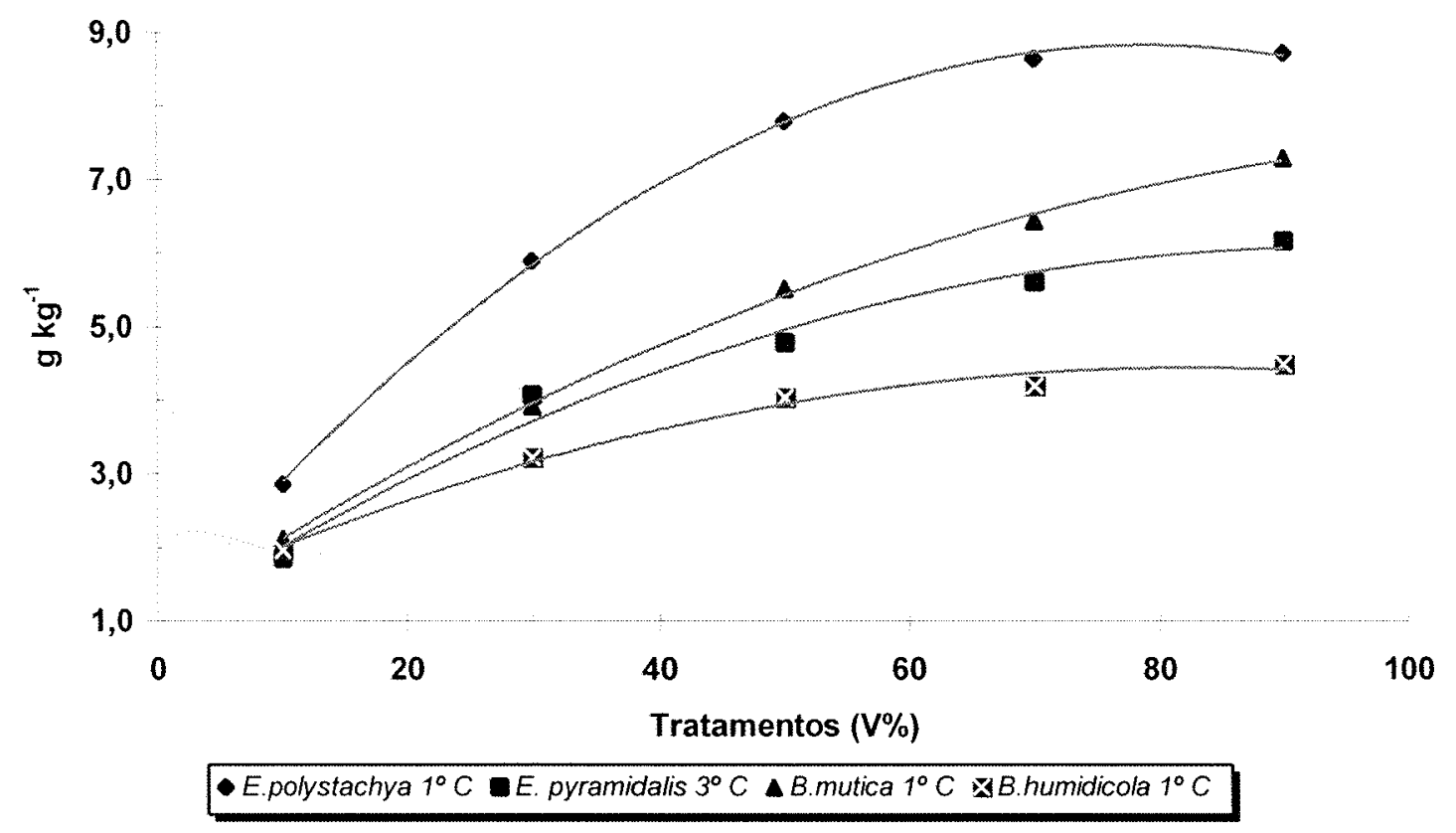

Figura 84- Teores de magnésio nas folhas das forrageiras, quando cultivadas no solo 1.

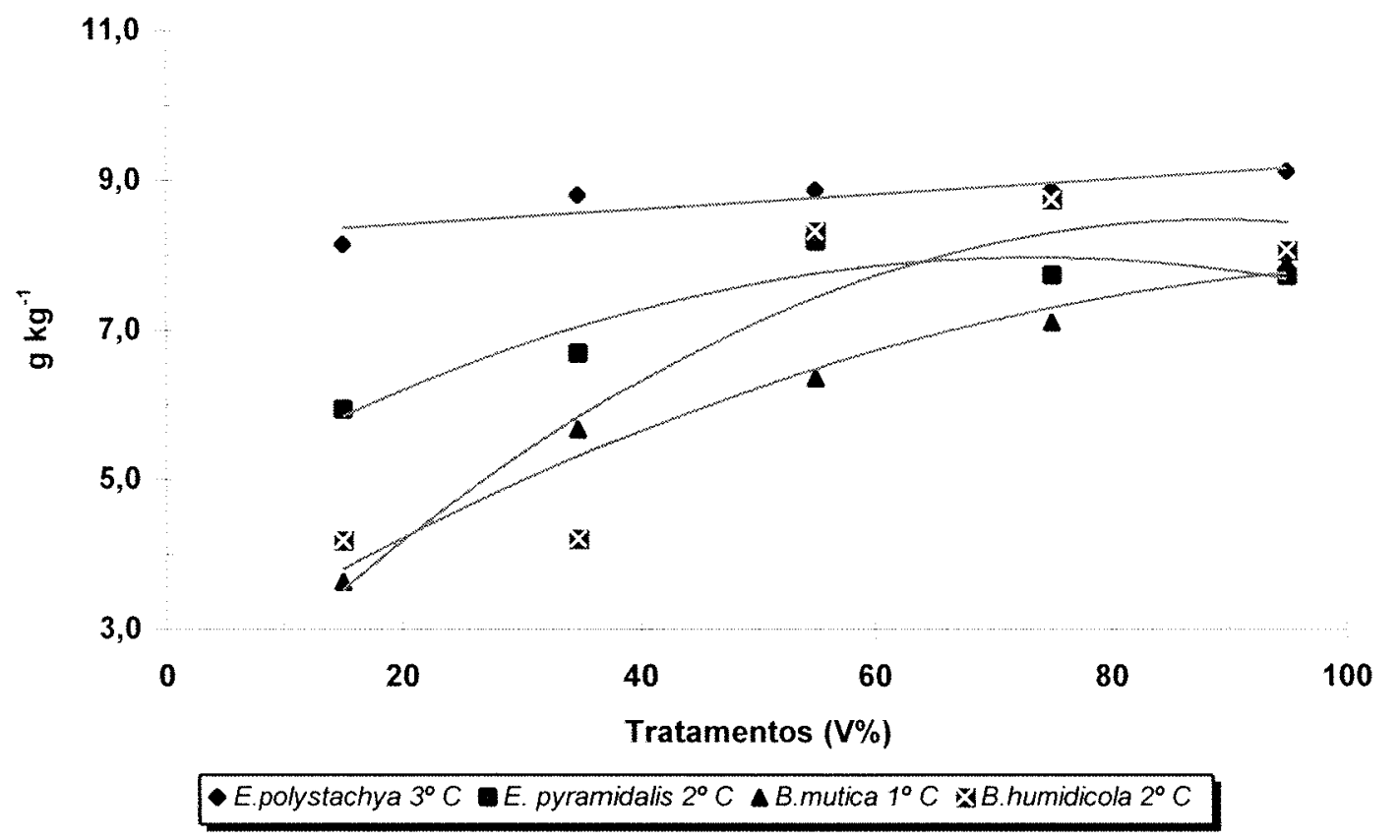

Figura 85- Teores de magnésio nas folhas das forrageiras, quando cultivadas no solo 2. 


\subsubsection{RELAÇÃ̃ CÁLCIO/MAGNÉSIO}

A relação $\mathrm{Ca}: \mathrm{Mg}$ encontrada nas folhas das forrageiras foram significativamente alteradas pelos tratamentos em 23 dos 24 cortes realizados, mostrando de forma geral no solol um comportamento de crescimento desta relação, atingindo pontos de máxima entre os tratamento V50 e V70 com queda subseqüente (Figura 86) e no solo2, as curvas mostraram crescimento até próximo ao tratamento V70, e certa estabilização posterior na maioria dos casos (Figura 87). As plantas cultivadas no solo2, o qual possuía menor relação $\mathrm{Ca} / \mathrm{Mg}$, também sempre apresentaram uma menor relação numérica $\mathrm{Ca} / \mathrm{Mg}$ nas folhas para todos os cortes, quando comparadas as cultivadas no solo1 (Figura 88). E ainda para confirmar este comportamento de influência preponderante do solo, com o avanço dos cortes e extração maior de $\mathrm{Mg}$ a cada corte, fez com que a relação aumentasse no solo e com isto também se elevasse nos tecidos foliares em quase todas as espécies avaliadas, com exceção da E. pyramidalis cultivada no solol que teve maior relação no 2 corte (Figura 88). Estes resultados mostram que as plantas apresentaram uma relação $\mathrm{Ca}: \mathrm{Mg}$ que refletiam as condições de solo.

Devido a grande maioria dos solos brasileiros apresentarem uma relação justamente oposta a estes em estudo, ou seja, sempre apresentarem relações onde o cálcio é predominante e muitas vezes precisando-se fazer uso de calcário calcítico, faz com que a grande maioria dos trabalhos publicados estudando a relação $\mathrm{Ca} / \mathrm{Mg}$ estivessem preocupados em como as forrageiras se comportariam em relações muito elevadas com vantagem para o cálcio. Neste enfoque trabalhos como de Marun (1990) e de Nogueira et al. (1997) verificaram reduções na absorção de $\mathrm{Mg}$ com elevação da relação $\mathrm{Ca} / \mathrm{Mg}$ do solo, tendo o primeiro autor verificado diminuição de produção da $B$. decumbens, B. brizantha e $P$. maximum com aumentos da relação $\mathrm{Ca} / \mathrm{Mg}$ presente no solo. Nogueira et al. (1997) testando relações $\mathrm{CaCO}_{3} / \mathrm{MgCO}_{3}$ (entre 1:0 até 20:1) aplicadas ao solo, verificaram que a máxima produção do $P$. purpureum foi obtida na relação 2:1, ocorrendo reduções de $23 \%$ na produção para a relação $20: 1$ e de $53 \%$ para a relação 1:0. Os resultados aqui obtidos também mostram que um excesso de $\mathrm{Mg}$ também interfere na absorção de Ca. Este comportamento da relação cálcio magnésio 
pode explicar o motivo de ter-se encontrado aumentos lineares na produção em algumas das forrageiras aqui estudadas, mostrando que possivelmente a planta tenha sido mais beneficiada devido a um aumento da relação $\mathrm{Ca} / \mathrm{Mg}$ a propriamente da elevação de saturação por bases do solo.

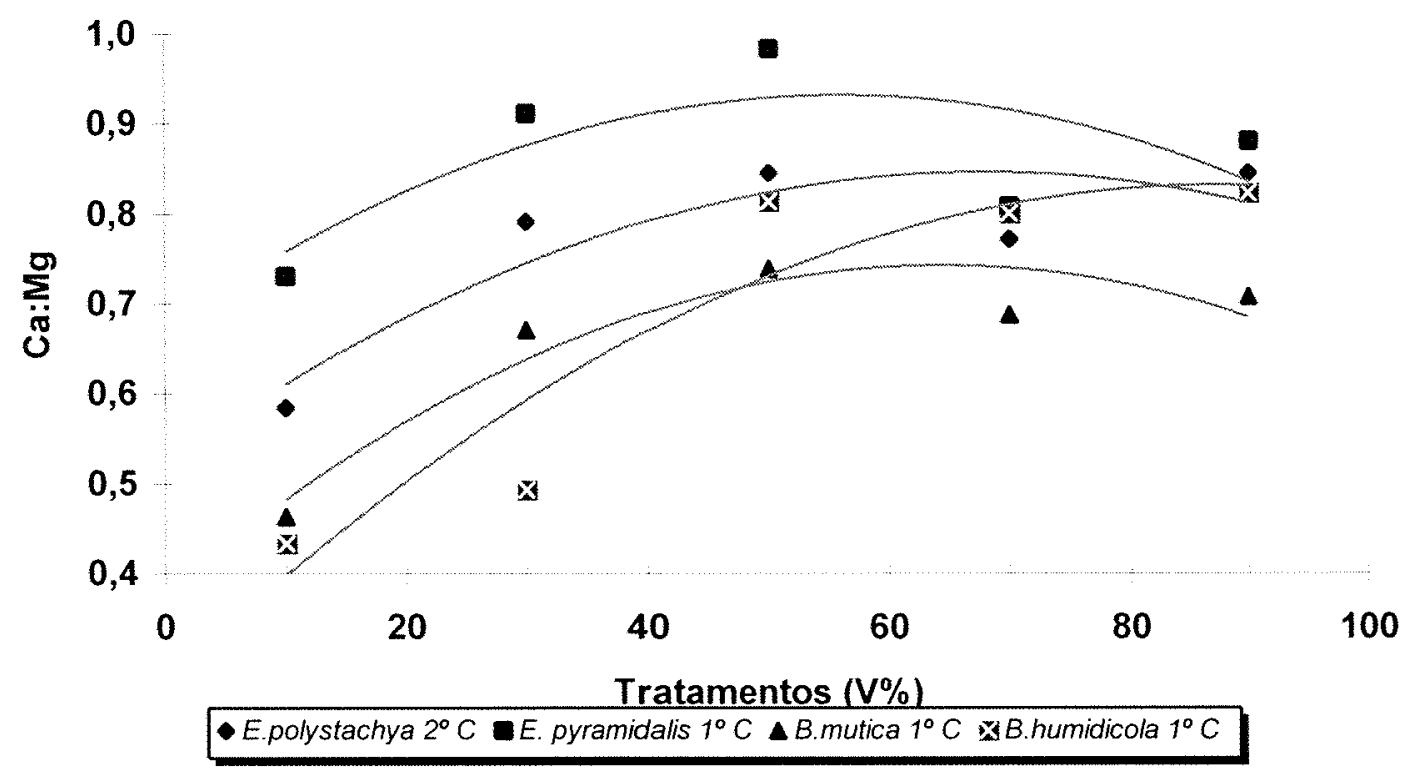

Figura 86- Relação Ca:Mg nas folhas das forrageiras, quando cultivadas no solo 1.

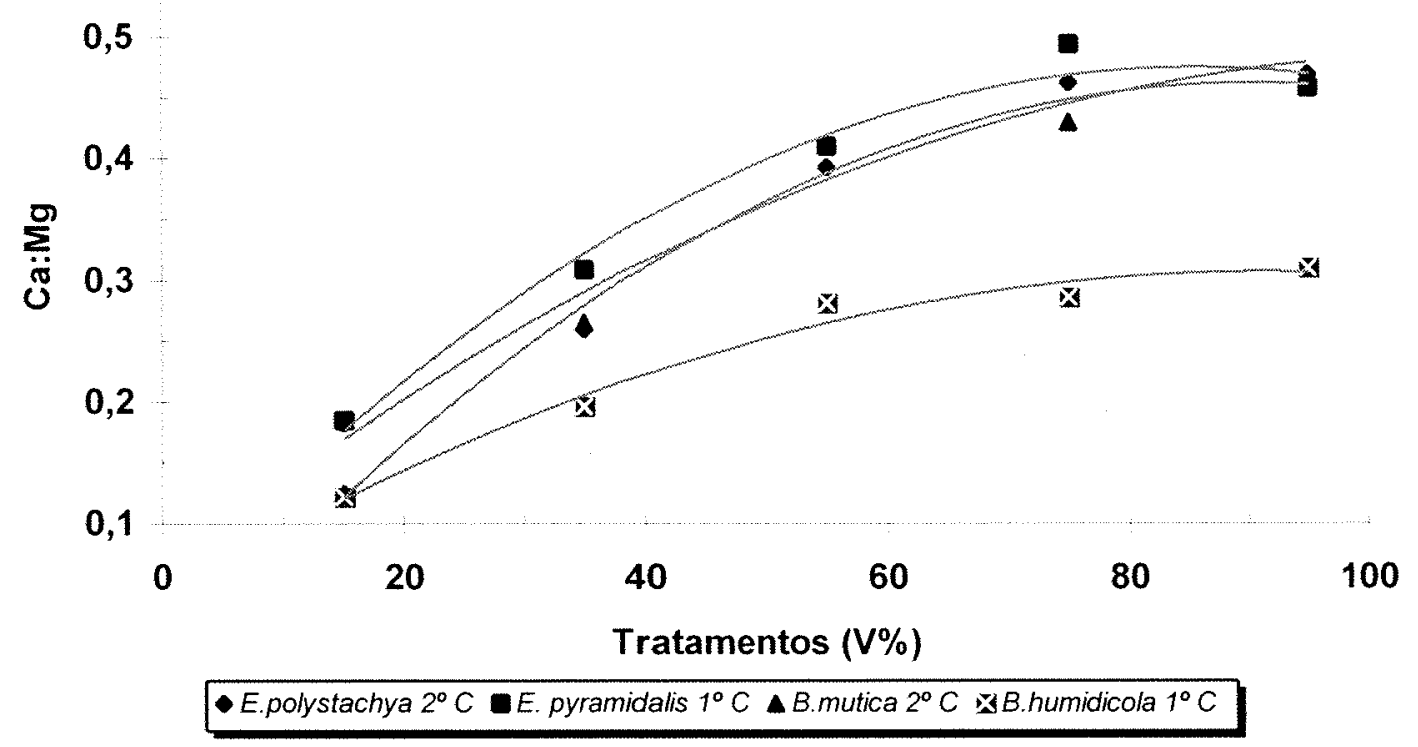

Figura 87- Relação Ca:Mg nas folhas das forrageiras, quando cultivadas no solo 2. 


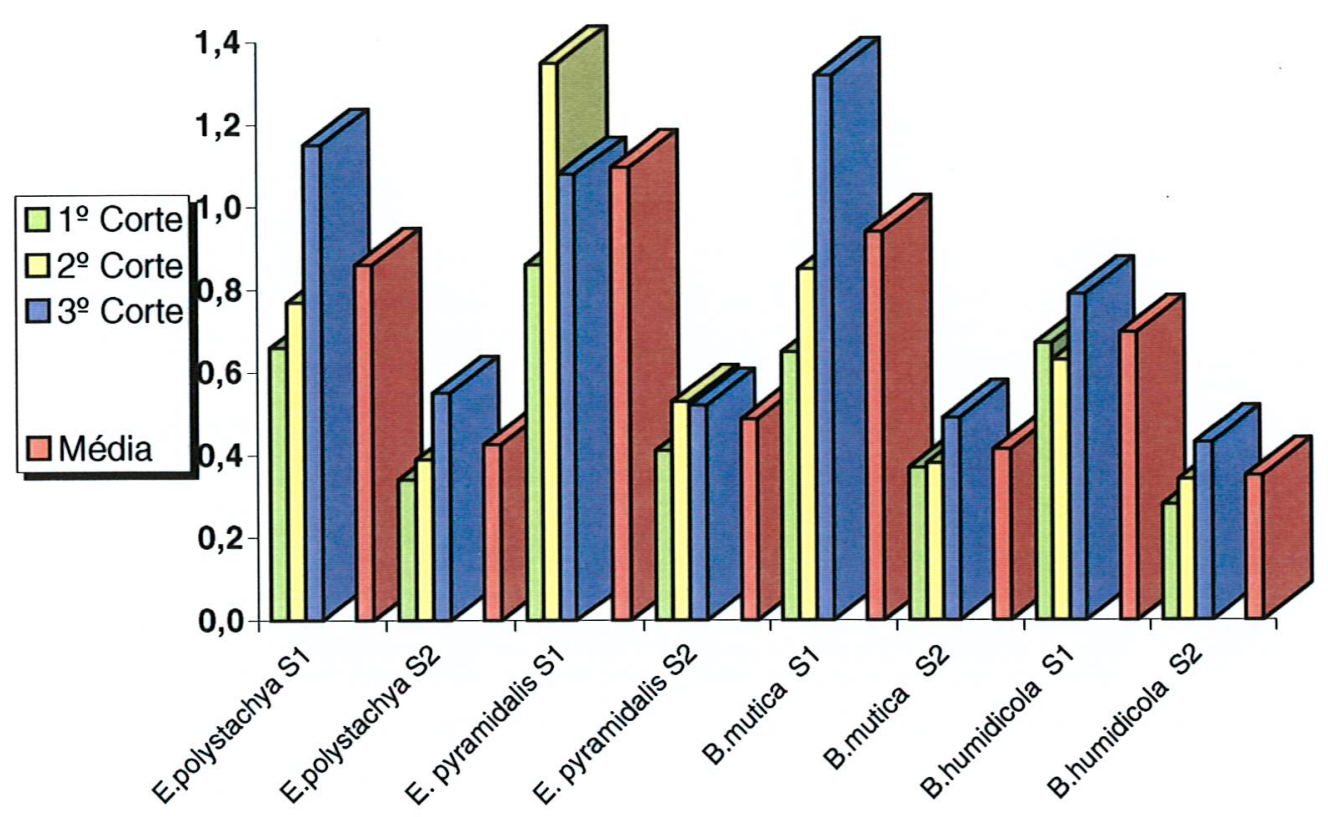

Figura 88- Relação Ca:Mg nas folhas das forrageiras ao longo dos cortes realizados.

\subsubsection{5́́}

Os teores de sódio tiveram comportamento semelhante ao potássio, porém o sódio mostrou-se com menor capacidade de competir com as demais bases do solo, já que dos 24 cortes realizados, em 14 teve sua concentração reduzida pelas doses crescentes de calcário (Figuras 89 e 90). Assim como o magnésio, os teores de sódio das plantas cultivadas no solo 2 sempre apresentaram maiores concentrações deste elemento, mostrando mais uma vez um reflexo das concentrações encontradas no solo, resultado este que está de acordo com Silva (1992), que observou aumentos dos teores de sódio nas forrageiras avaliadas com o aumento deste elemento na solução nutritiva. E ainda, esta mesma autora observou aumentos nos teores de sódio com o aumento de $\mathrm{Ca}$ na solução nutritiva, sendo assim estes resultados de redução de $\mathrm{Na}$ com aumento das doses de calcário que introduziram $\mathrm{Ca}$ e Mg no sistema podem estar mais ligadas a uma competição com o magnésio. 


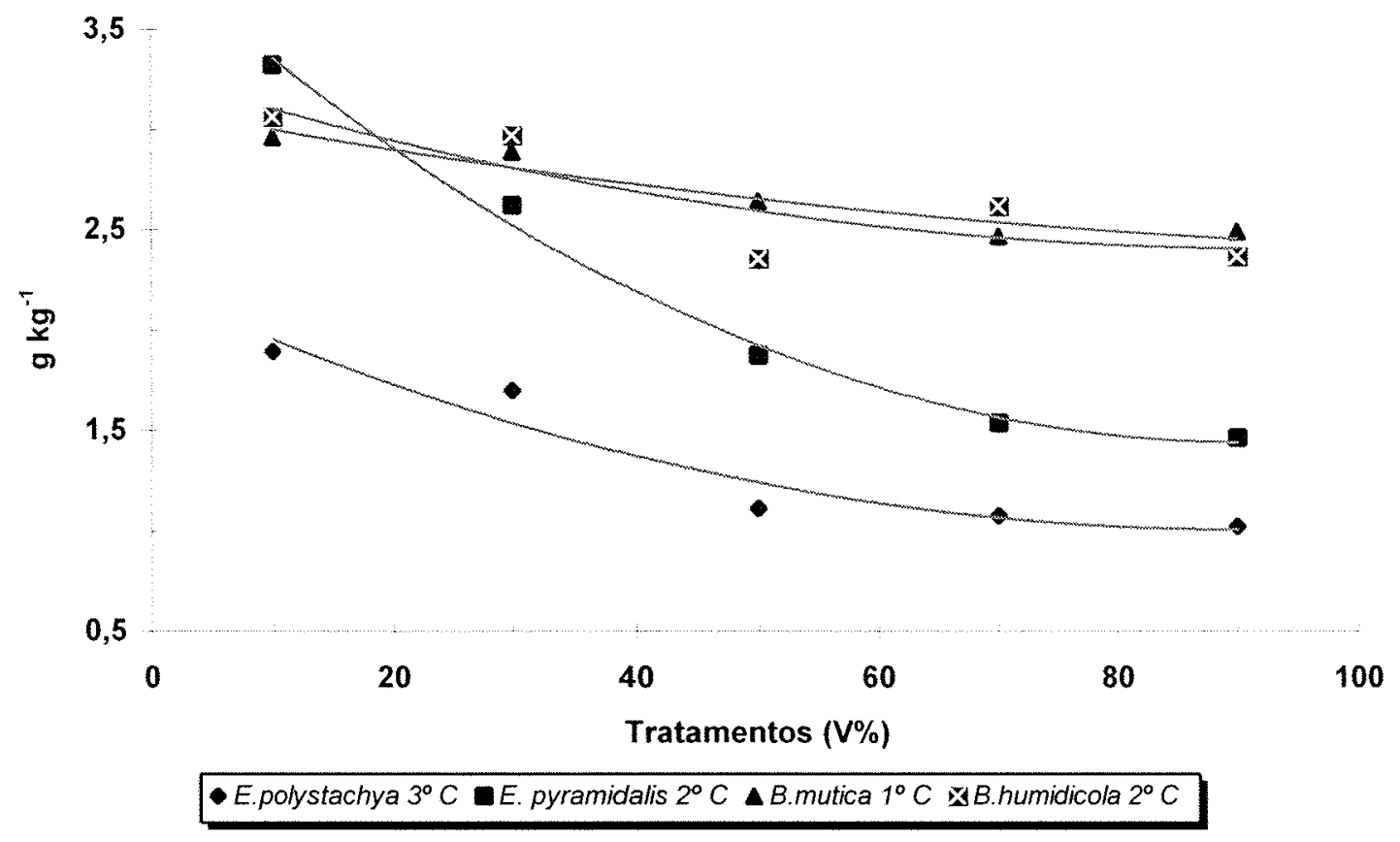

Figura 89- Teores de sódio nas folhas das forrageiras, quando cultivadas no solo 1.

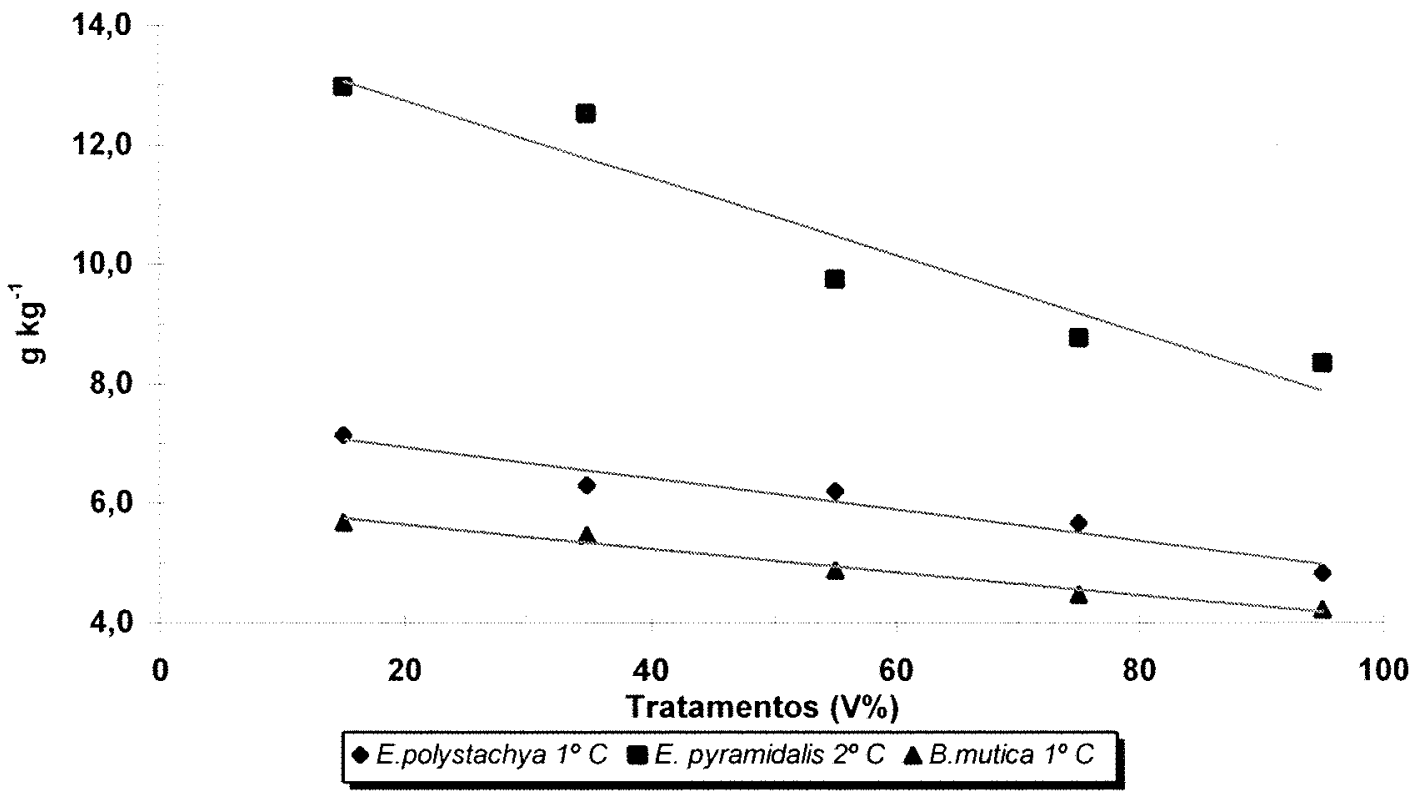

Figura 90- Teores de sódio nas folhas das forrageiras, quando cultivadas no solo 2 . 


\subsubsection{ENXOFRE}

Os teores de enxofre tiveram comportamento significativo em 9 dos 24 cortes realizados mostrando de forma geral, aumentos com a elevação da saturação por bases (Figuras 91 e 92), comportamento também registrado por Mitidieri (1995). Para gênero Echinochloa foram verificadas 7 das 9 ocorrências em que o teor de enxofre foi significativo. As plantas cultivadas no solo2, o qual possuía maiores teores deste elemento sempre tiveram maiores concentrações de $\mathrm{S}$ nas folhas, e esta diferença foi mais acentuada para o gênero Echinochloa, mostrando ser este gênero mais influenciado pelo S disponível no solo.

$\mathrm{O}$ aumento dos teores de enxofre com crescentes de saturações por bases no solo podem ser explicados pelo aumento do $\mathrm{pH}$ do solo, promovendo a liberação de sulfatos ligados a $\mathrm{Fe}$ e $\mathrm{Al}$ e ao favorecimento da mineralização da matéria orgânica existente no solo (Defilipo, 1990), transformando formas de S orgânico em formas que possam ser assimiladas pela planta, aumentando portanto a disponibilidade do mesmo para as forrageiras. Em 6 das 9 vezes em que o teor de enxofre se mostrou significativo, este ocorreu no solo2, justamente o solo com maior quantidade de mátria orgânica.

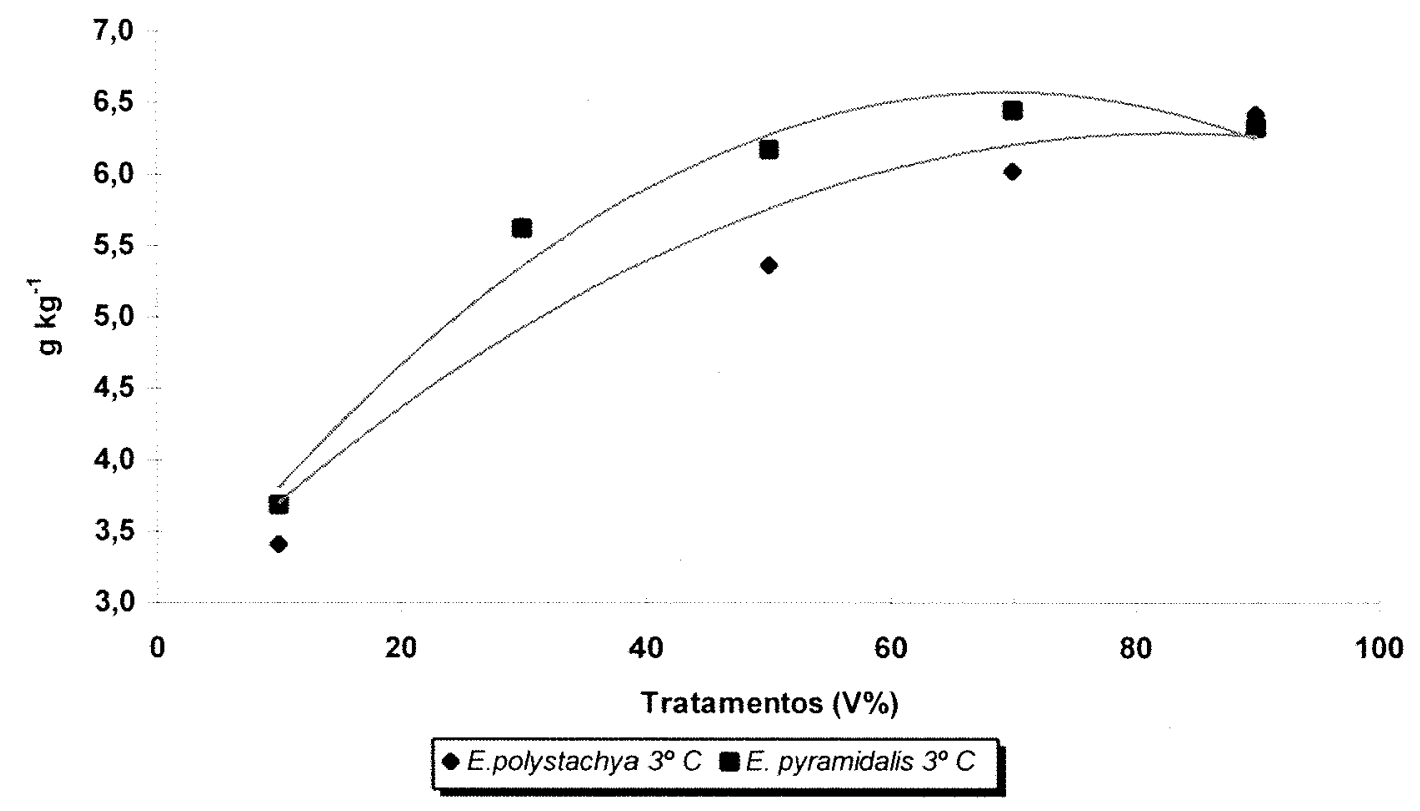

Figura 91- Teores de enxofe nas folhas das forrageiras, quando cultivadas no solo 1. 


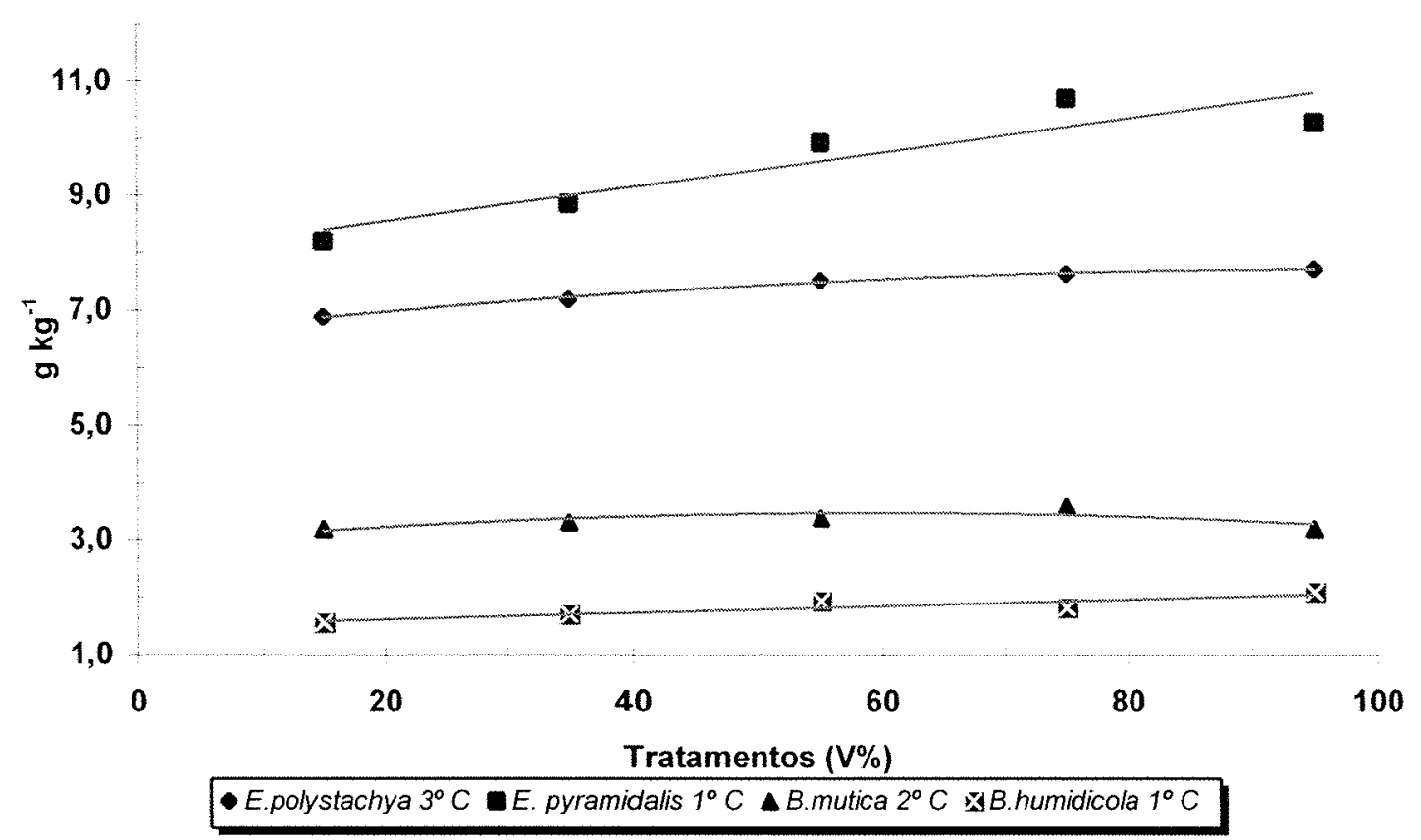

Figura 92- Teores de enxofre nas folhas das forrageiras, quando cultivadas no solo 2.

\subsubsection{CIBRE, FERRI, MANGANẾ E ZINCD}

Os teores de cobre, ferro, manganês e zinco, quando significativos, tiveram de forma geral um comportamento de redução em relação as crescentes doses de calcário utilizadas. A diminuição da disponibilidade destes micronutrientes com o aumento do $\mathrm{pH}$, é um comportamento clássico para quase todas as espécies vegetais sendo reportado como característica dos efeitos da calagem ou da elevação de ph do solo, por diversos autores como: Malavolta et al. (1989), Defelipo (1990), Raij (1991) e Jorge (1993). Contudo como será apresentado, devido ao solo ter recebido adubações de alguns destes micronutrientes, quando a análise de solo revelou valores baixos, portanto, as esperadas reduções no teor destes elementos no tecido vegetal não ocorreram em todos os casos.

Os teores de cobre nas folhas tiveram efeito significativo em 9 cortes dos 24 realizados (Figuras 94 e 95), sendo explicados por retas decrescentes (6 observações) ou por curvas quadráticas com ponto de mínima em relação às doses crescentes de 
calcário nos demais casos em que foi significativo, concordando com alguns resultados obtidos por Premazzi (1991) e Mitidieri (1995).

Os teores de ferro foram estatisticamente significativos em 13 dos 24 cortes efetuados (Figuras 96 e 97), sendo explicados por retas decrescentes em 5 observações ou ainda por curvas quadráticas com ponto de mínima em relação às doses crescentes de calcário nos outros 8 cortes em que foi significativo. Esta redução está de acordo com alguns resultados obtidos também por Colozza (1993) e discordando de resultados obtidos por Mitidieri (1995) que em algumas situações registrou aumento dos teores de Fe com a calagem.

Os teores de manganês foram significativos em 23 dos 24 corte (Figuras 98 e 99), confirmando o papel da calagem como eficiente redutora dos teores de $\mathrm{Mn}$, elemento este que muitas vezes se torna tóxicos para as planta. Em 8 ocasiões valores foram decrescentes explicados por retas lineares em função das crescentes saturações por bases. Sendo explicado nas demais ocasiões por curvas quadráticas, nas quais 13 vezes apresentaram pontos de mínima com certa estabilização após este ponto, e em outras 2 oportunidades apresentando ponto de máxima próximo a primeira dose aplicada do corretivo com posterior declínio das concentrações, sendo tal comportamento verificado par a $B$. humidicola no segundo corte para ambos os solos. Reduções nos teores de Mn também foram verificados por Abruña et al.(1964), Premazzi (1991), Colozza (1993), Mitidieri (1995). Segundo Malavota et al. (1989) os sintomas de Mn em gramíneas são caracterizados por pontos necróticos nas folhas mais velhas, sintoma este verificado para as espécies do gênero Echinochloa, com maior incidência para a $E$. polystachya nas parcelas testemunha de ambos os solos no $2^{\circ}$ e $3^{\circ}$ corte (Figura 93).

Os teores de zinco foram significativos em 16 dos 24 cortes realizados (Figuras 100 e 101), apresentando um comportamento linear decrescente em 5 oportunidades, e em 6 oportunidades foi explicado por equações quadráticas com ponto de mínima, mostrando redução dos teores com aumento das doses de calcário, seguindo de certa estabilização e finalmente nas outras 5 vezes em que foi significativo, foi também explicado por equações quadráticas porém atingindo pontos de máxima próximos a 
primeira dosagem de corretivo, reduzindo-se em diante. Resultados de redução nos teores de Zn em forrageiras, também foram obtidos por Premazzi (1991) e Mitidieri (1995).

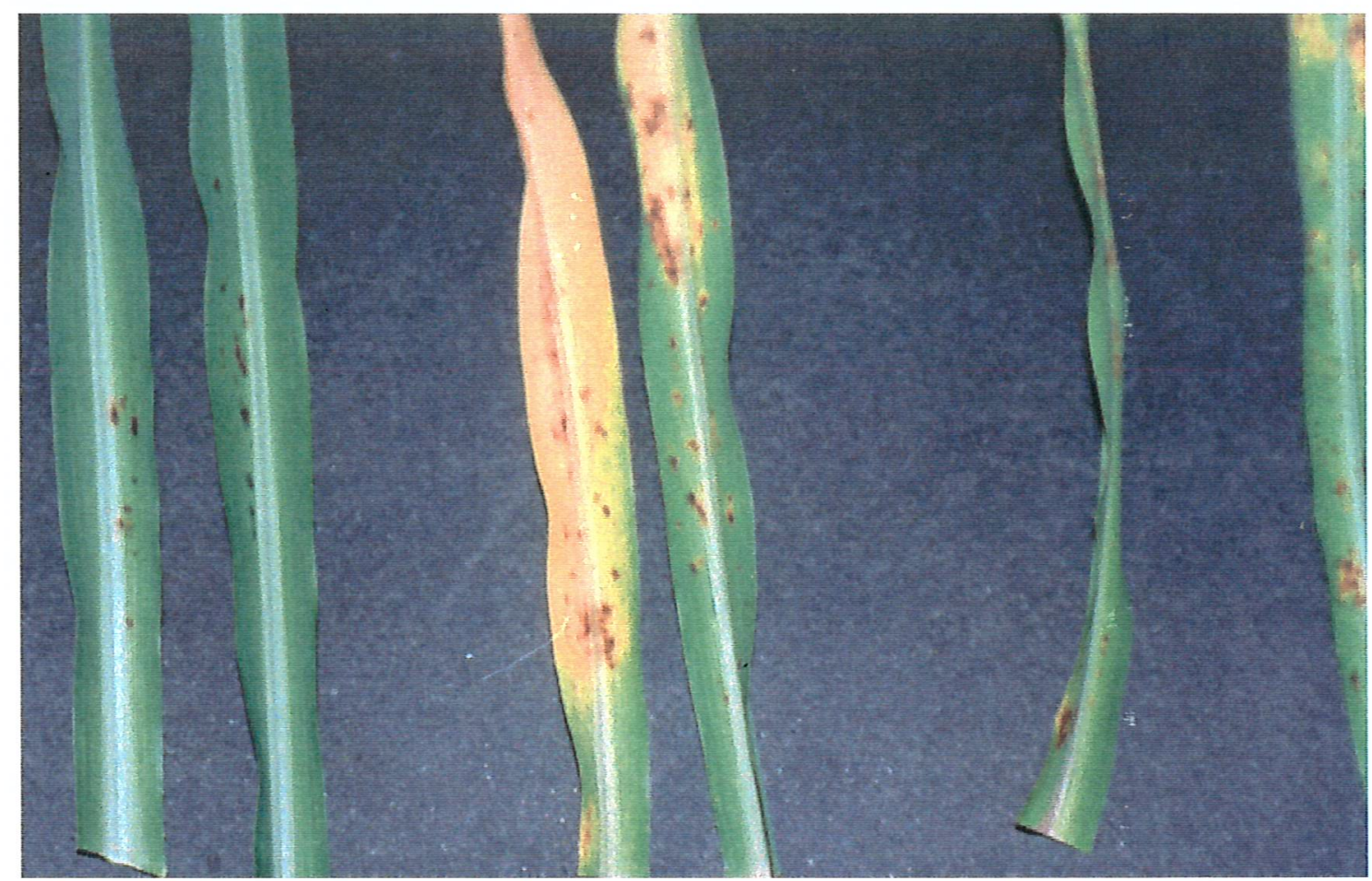

Figura 93- Possível Toxidez de Manganês, verificada na espécie E. polystachya. O sintoma se caracterizou pelo surgimento inicial de pontos necróticos nas folhas mais velhas, sequido de amarelecimento em volta destes pontos, até o total amarelecimento das folhas.

\subsubsection{BRRD}

Os teores de boro apresentaram comportamento significativo em 18 dos 24 cortes realizados (Figuras 102 e 103), apresentando um comportamento linear crescente em 7 oportunidades e explicado nas demais situações por equações quadráticas com ponto de máxima. Este comportamento dos teores de $\mathrm{B}$ em função de doses crescentes de calcário em forrageiras também foi verificado nos trabalhos de Premazzi (1991) e Mitidieri (1995). 


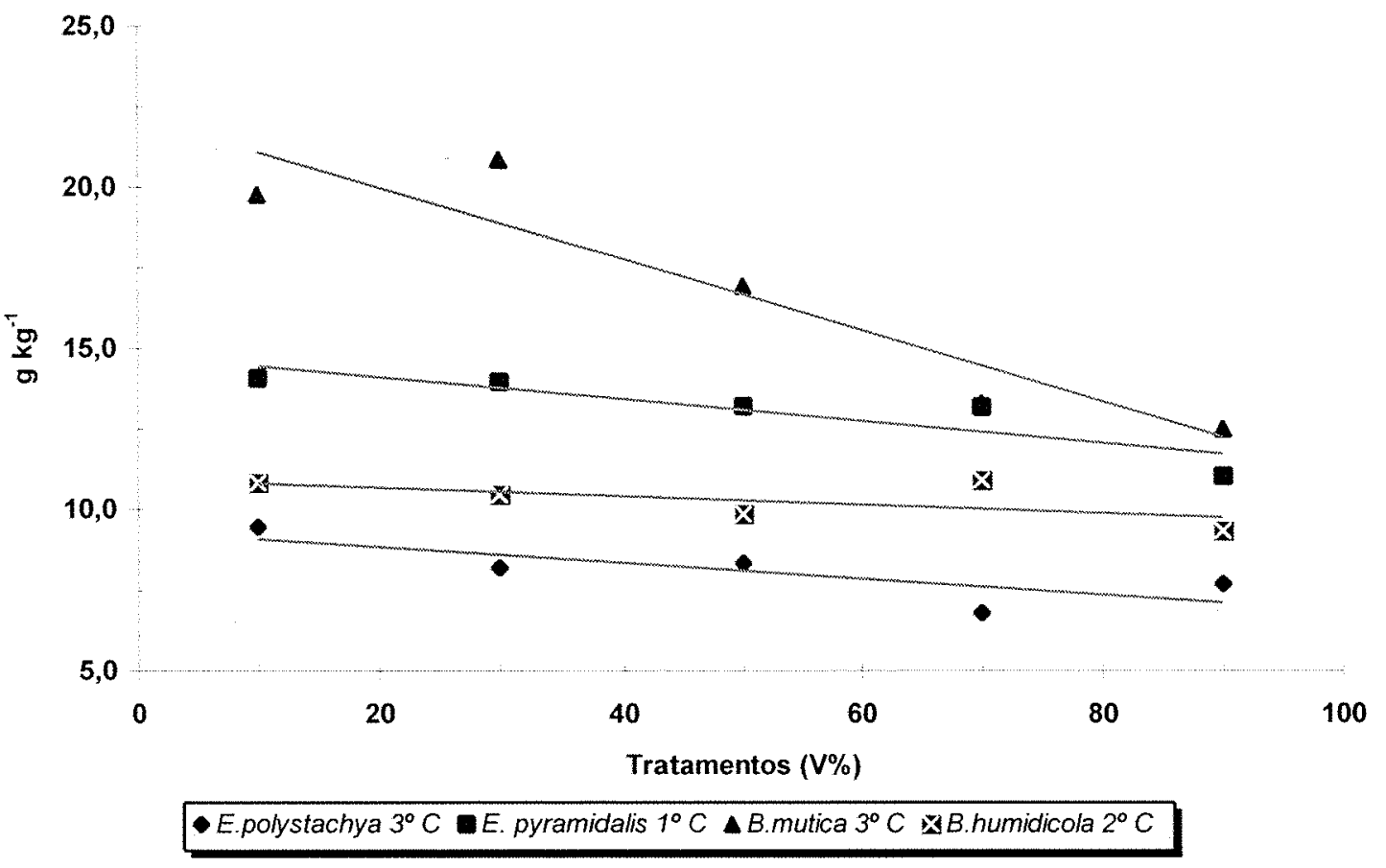

Figura 94- Teores de cobre nas folhas das forrageiras, quando cultivadas no solo 1.

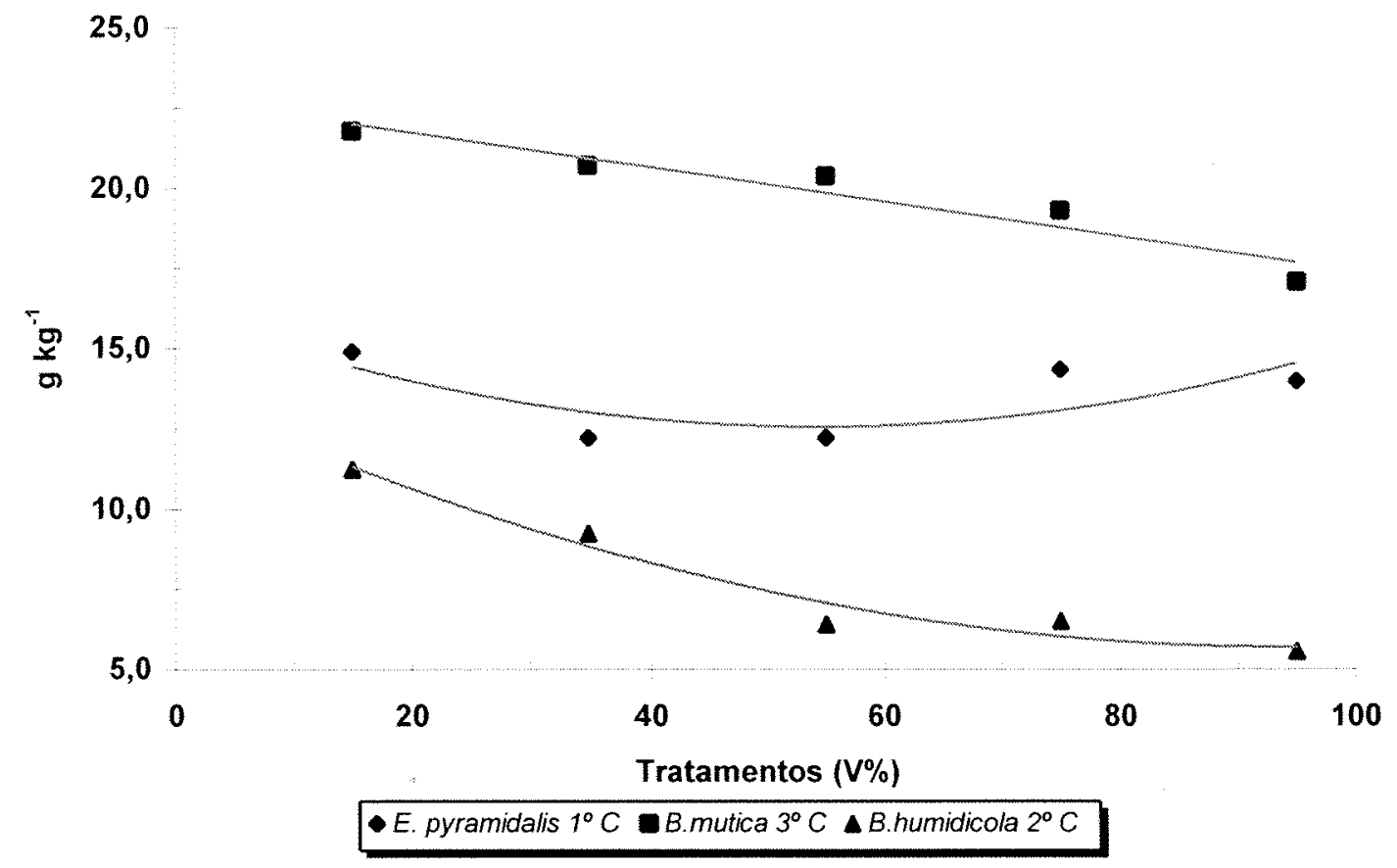

Figura 95- Teores de cobre nas folhas das forrageiras, quando cultivadas no solo 2. 


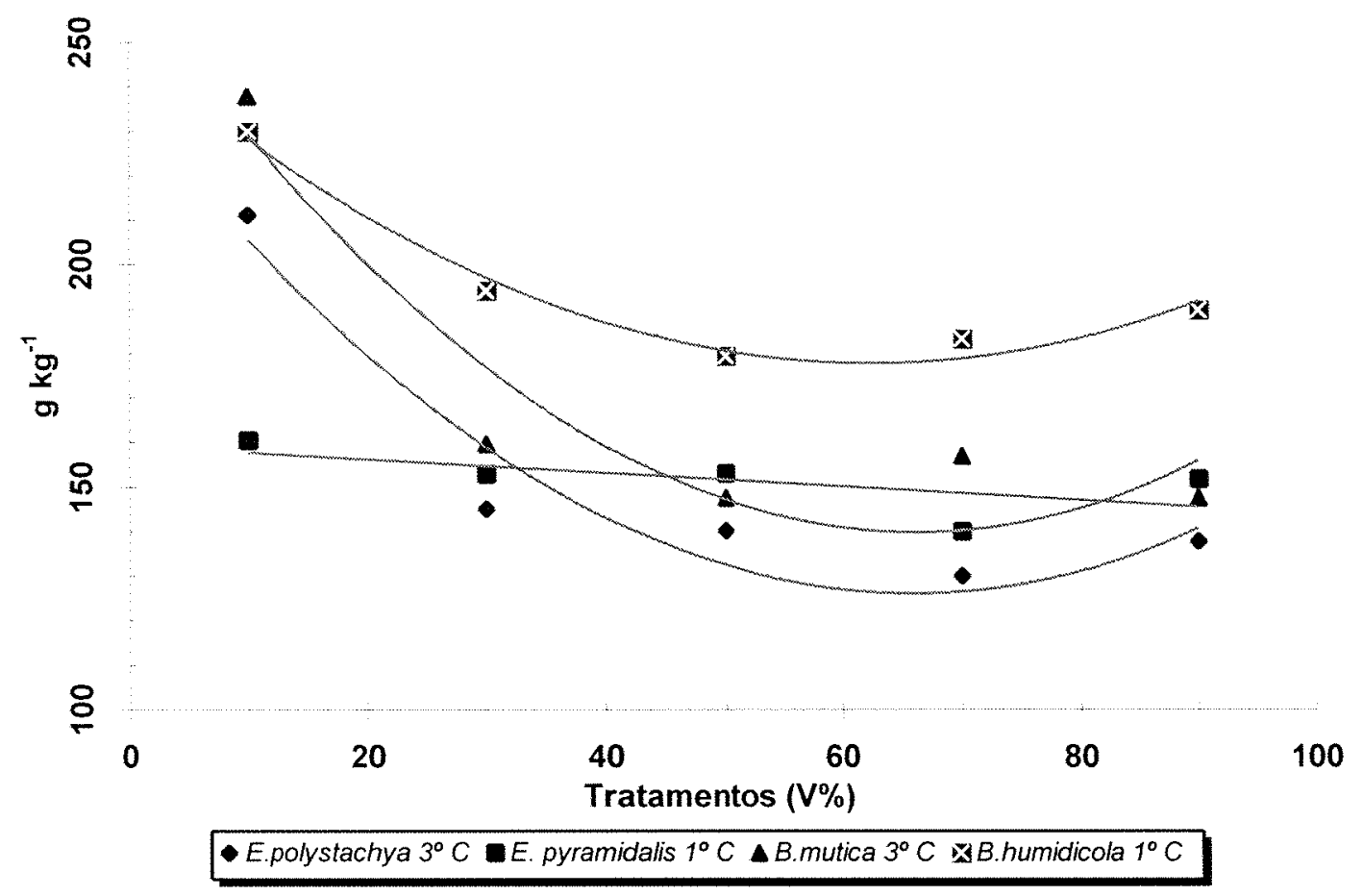

Figura 96- Teores de ferro nas folhas das forrageiras, quando cultivadas no solo 1.

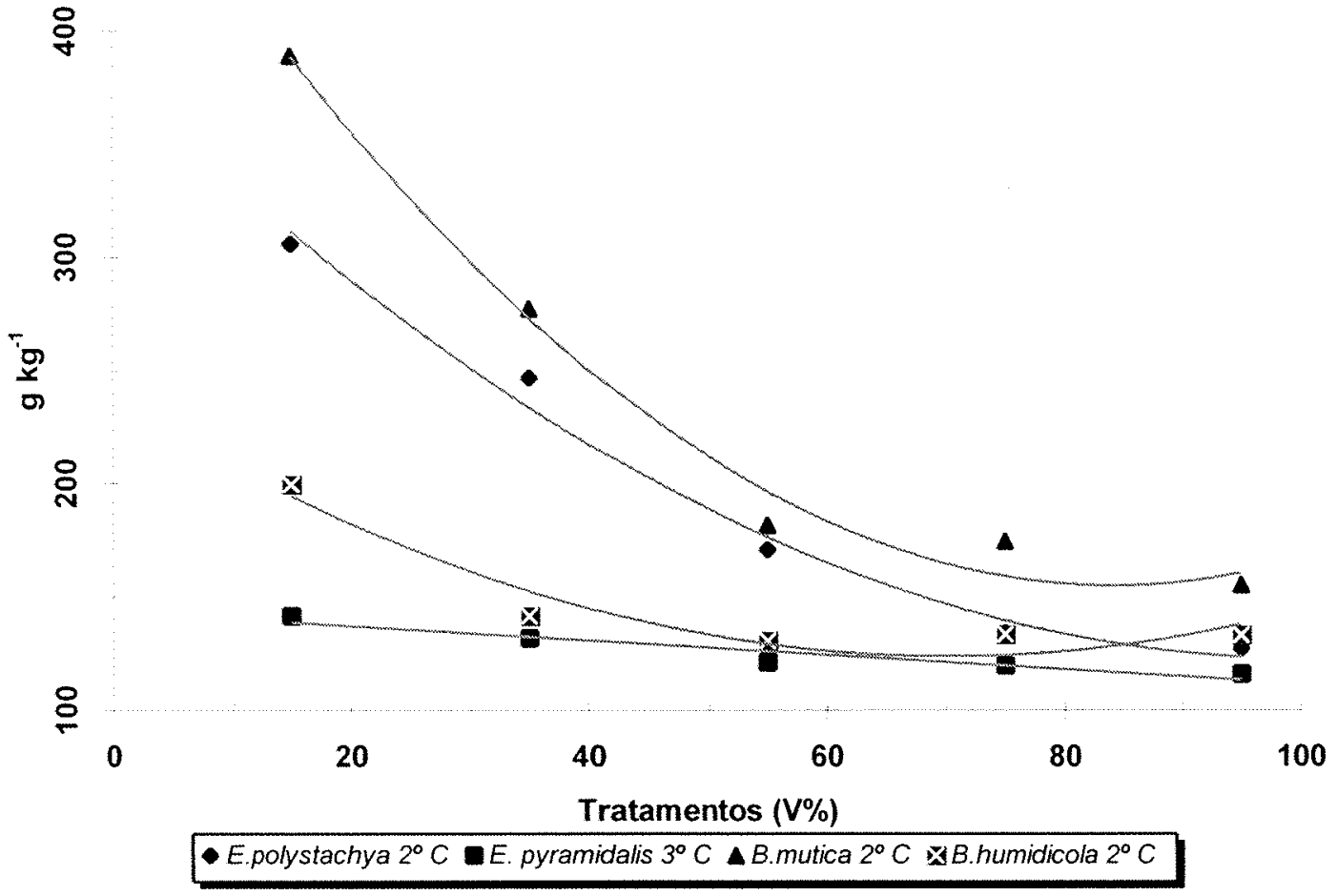

Figura 97- Teores de ferro nas folhas das forrageiras, quando cultivadas no solo 2. 


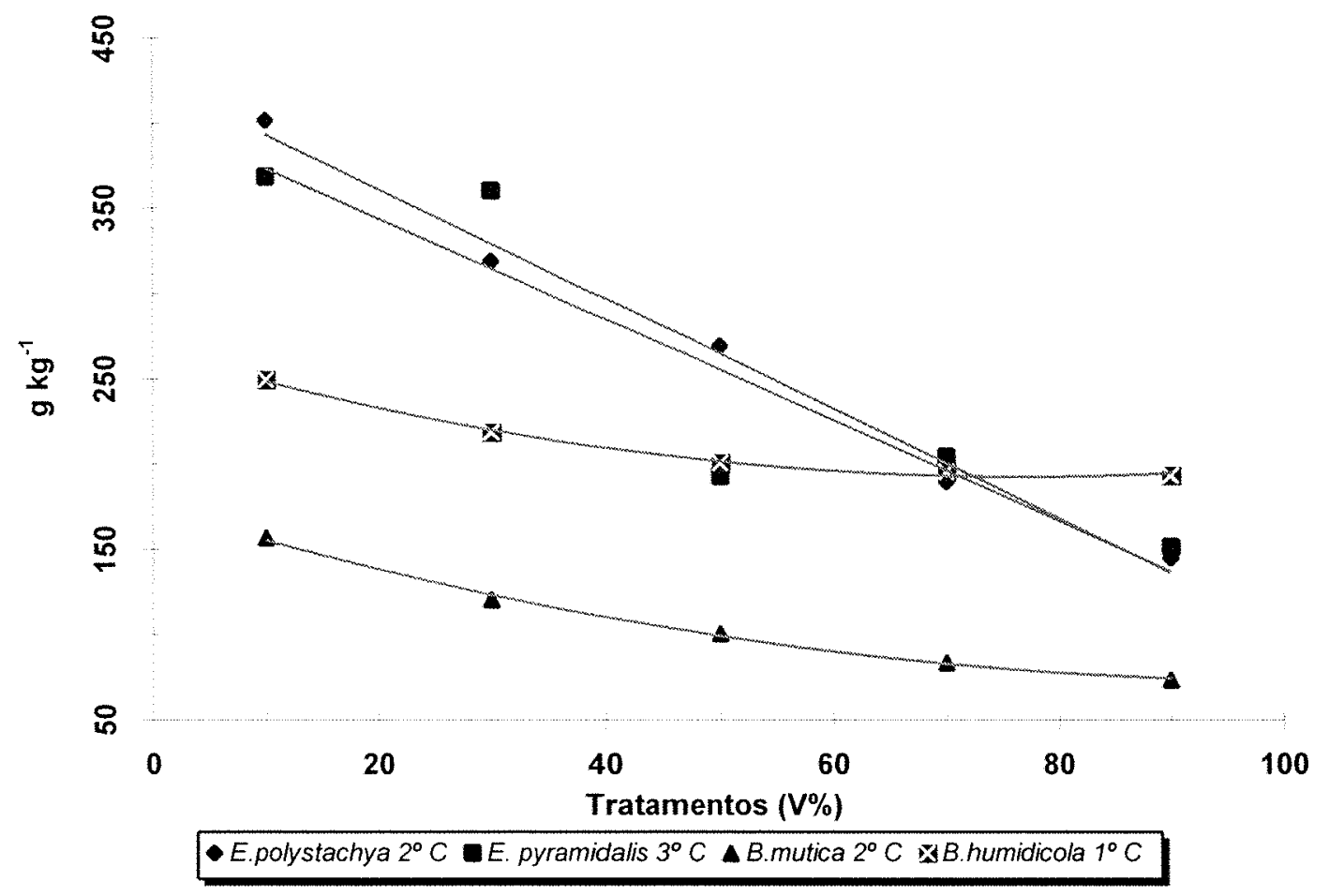

Figura 98- Teores de manganês nas folhas das forrageiras, quando cultivadas no solo 1.

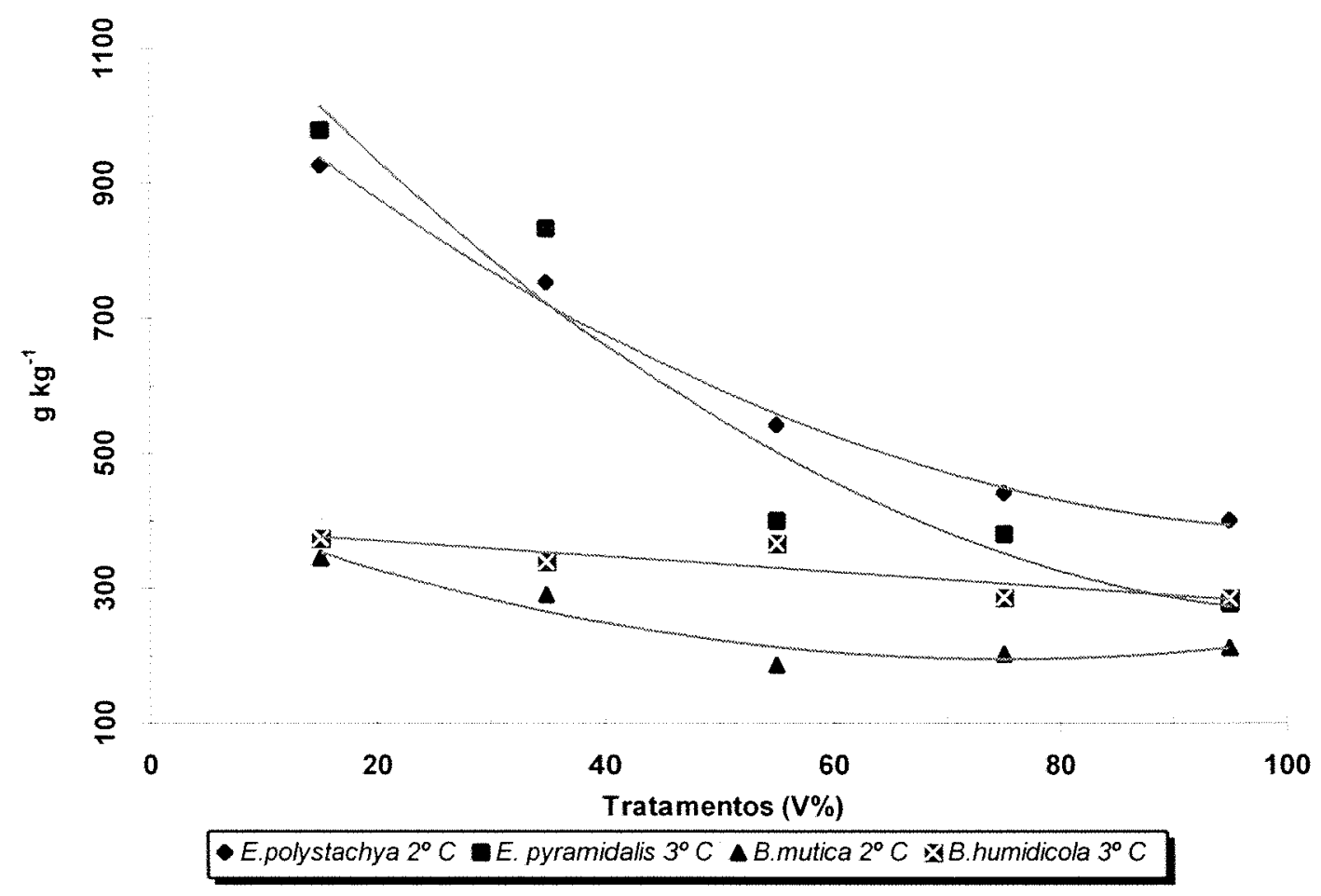

Figura 99- Teores de manganês nas folhas das forrageiras, quando cultivadas no solo 2. 


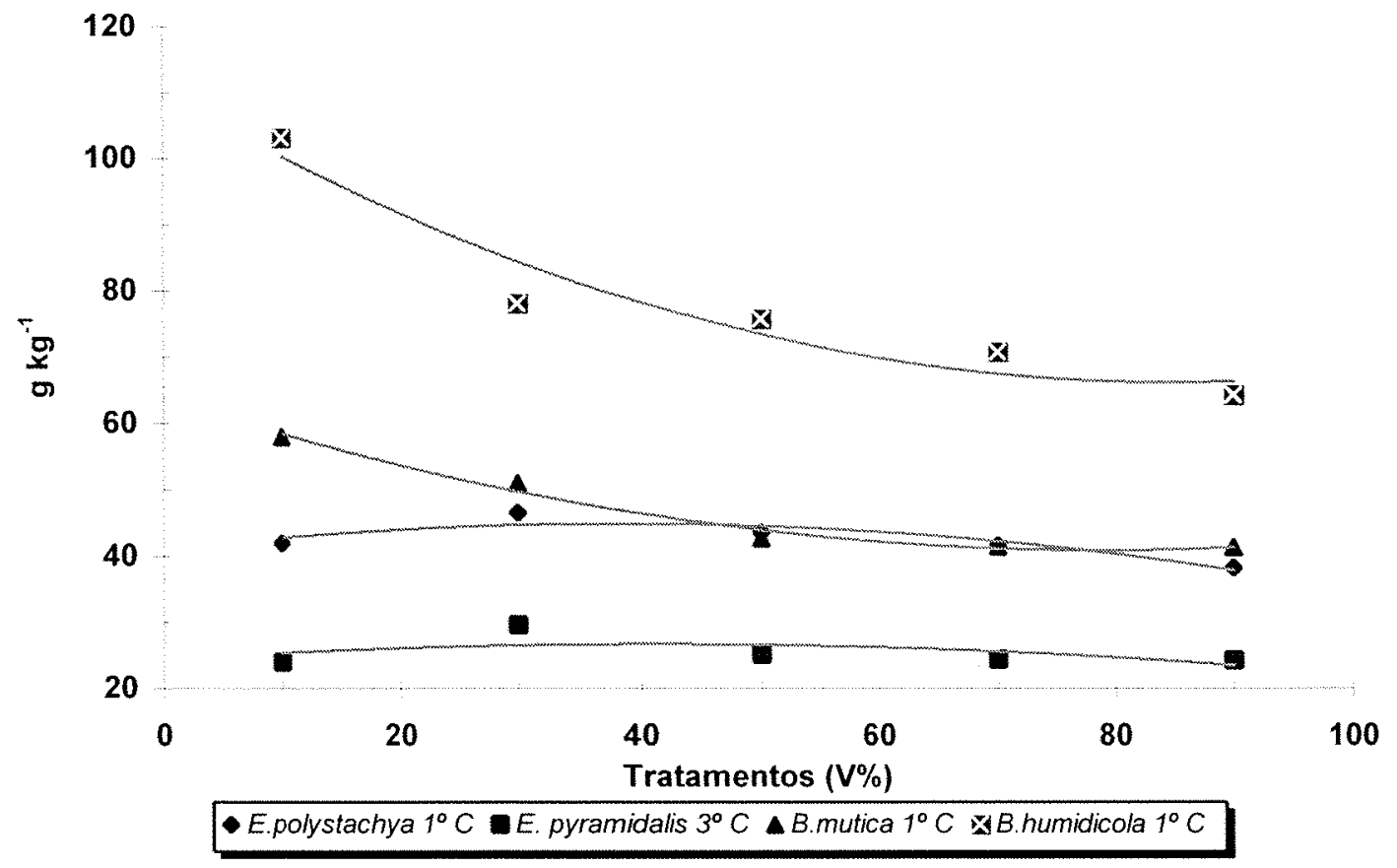

Figura 100-Teores de zinco nas folhas das forrageiras, quando cultivadas no solo 1.

70

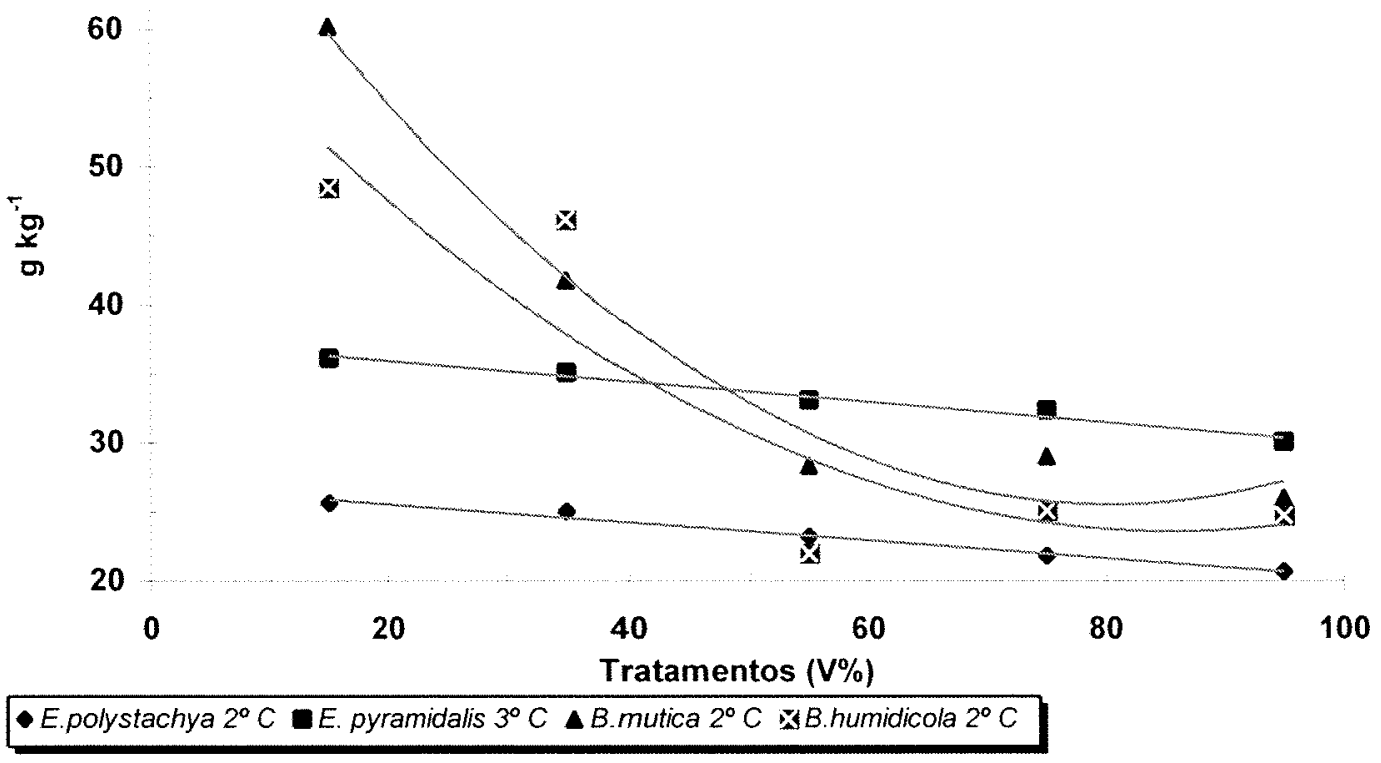

Figura 101- Teores de zinco nas folhas das forrageiras, quando cultivadas no solo 2. 


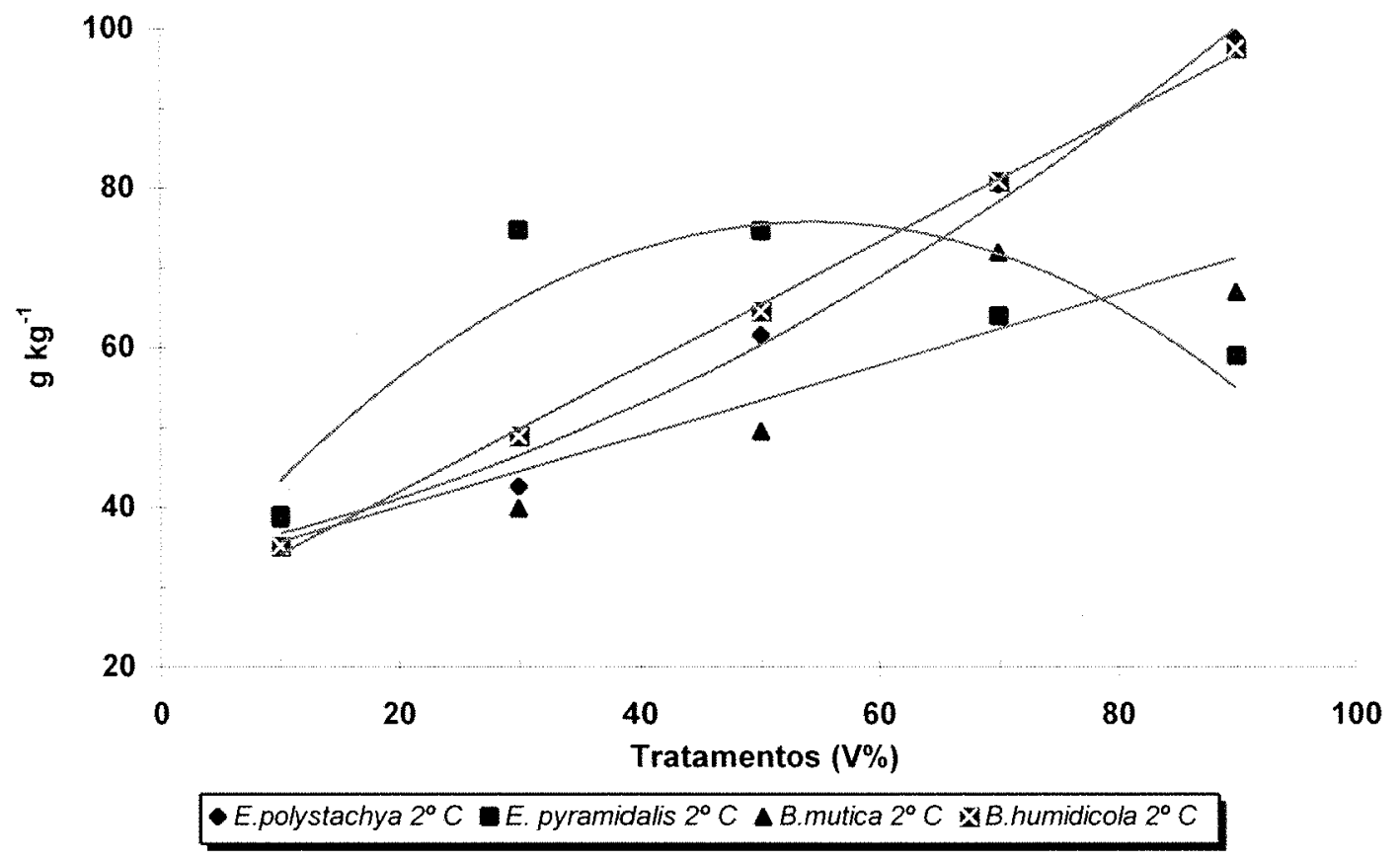

Figura 102- Teores de boro nas folhas das forrageiras, quando cultivadas no solo 1.

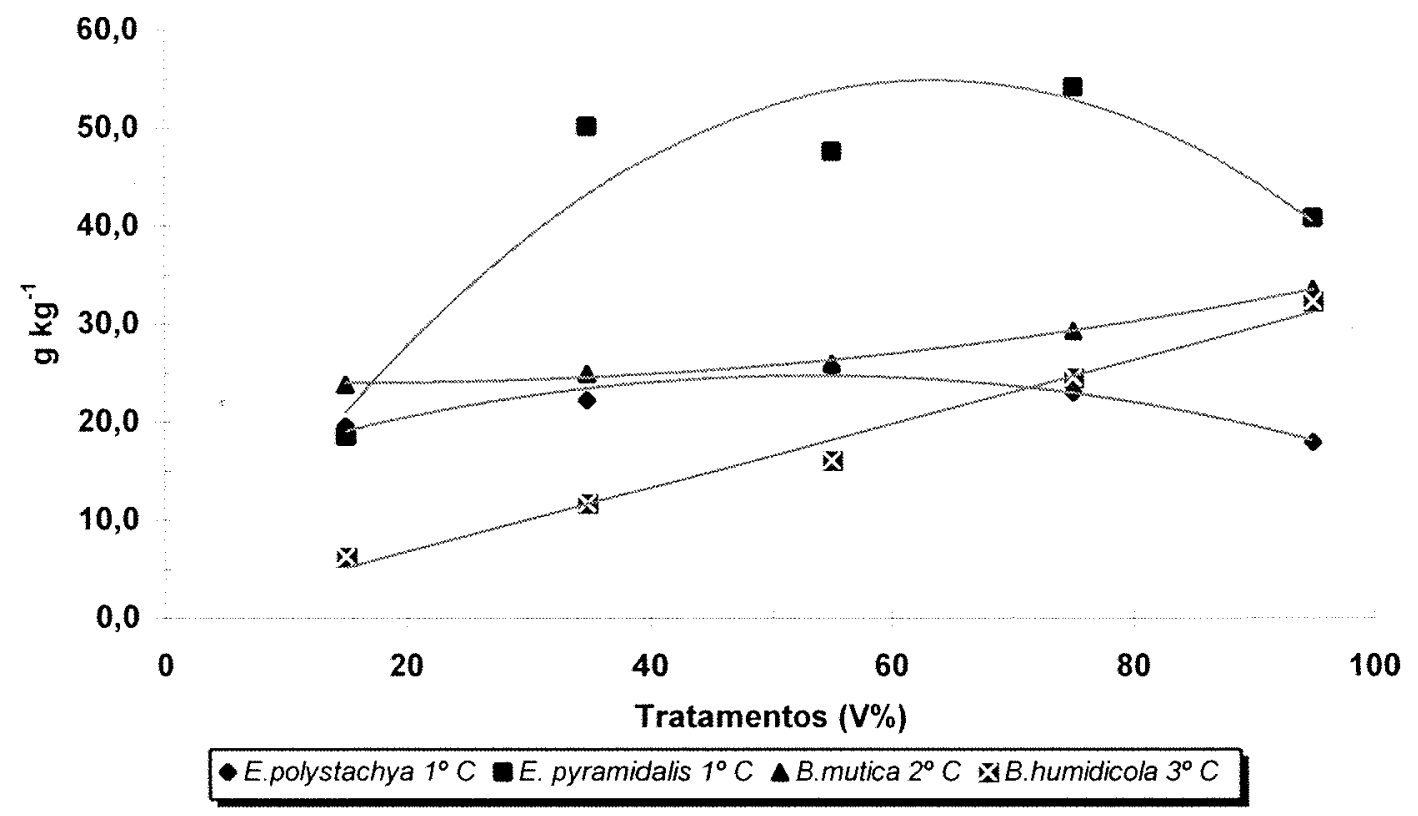

Figura 103- Teores de boro nas folhas das forrageiras, quando cultivadas no solo 2. 


\subsubsection{CINSIDERAÇãES FINAIS SOBRE COMPOSIÇÃa qUÍMICA}

Se confrontarmos os teores médios encontrados para os minerais hora avaliados com a faixa de normalidade citada no Boletim Técnico 100 (Raij et al.,1996) para espécies de gramíneas do grupol (grupo de maior exigência), verifica-se que o cálcio foi o único macronutriente que ficou abaixo da faixa de normalidade em algumas situações, principalmente nos tratamentos testemunha e na primeira dosagem de calcário aplicada, e ainda para as espécies do gênero Braquiária em outros tratamentos.

Quanto aos micronutrientes, o boro em algumas oportunidades no solo 2 se encontrou abaixo e no solo 1 acima da faixa de normalidade respectivamente e ainda o $\mathrm{Mn}$, principalmente com o avanço da acidificação do solo chegou a apresentar valores de 3 a 4 vezes maiores que o valor superior da faixa de normalidade.

Coincidentemente estes resultados refletem os sintomas visuais verificados durante a condução do experimento que foram justamente deficiências de cálcio e toxidez de Manganês, e ainda atribui como benefício da calagem o fornecimento de cálcio e a neutralização de $\mathrm{Mn}$, resultados estes, que possivelmente foram responsáveis pelo aumento de produção verificado em algumas espécies diante das doses crescentes de calcário aplicadas ao solo. O que confirma o resultados amplamente verificados na literatura do papel da calagem como fornecedora de $\mathrm{Ca}$ e $\mathrm{Mg}$, e no caso específico destes solos avaliados por terem uma riqueza natural de $\mathrm{Mg}$, a função da calagem foi mais específica em fornecer o cálcio. E ainda confirma o benefício da calagem em reduzir elementos tóxicos como o $\mathrm{Mn}$, que se tornam extremante elevados, quando se pratica elevadas fertilizações nitrogenadas. 


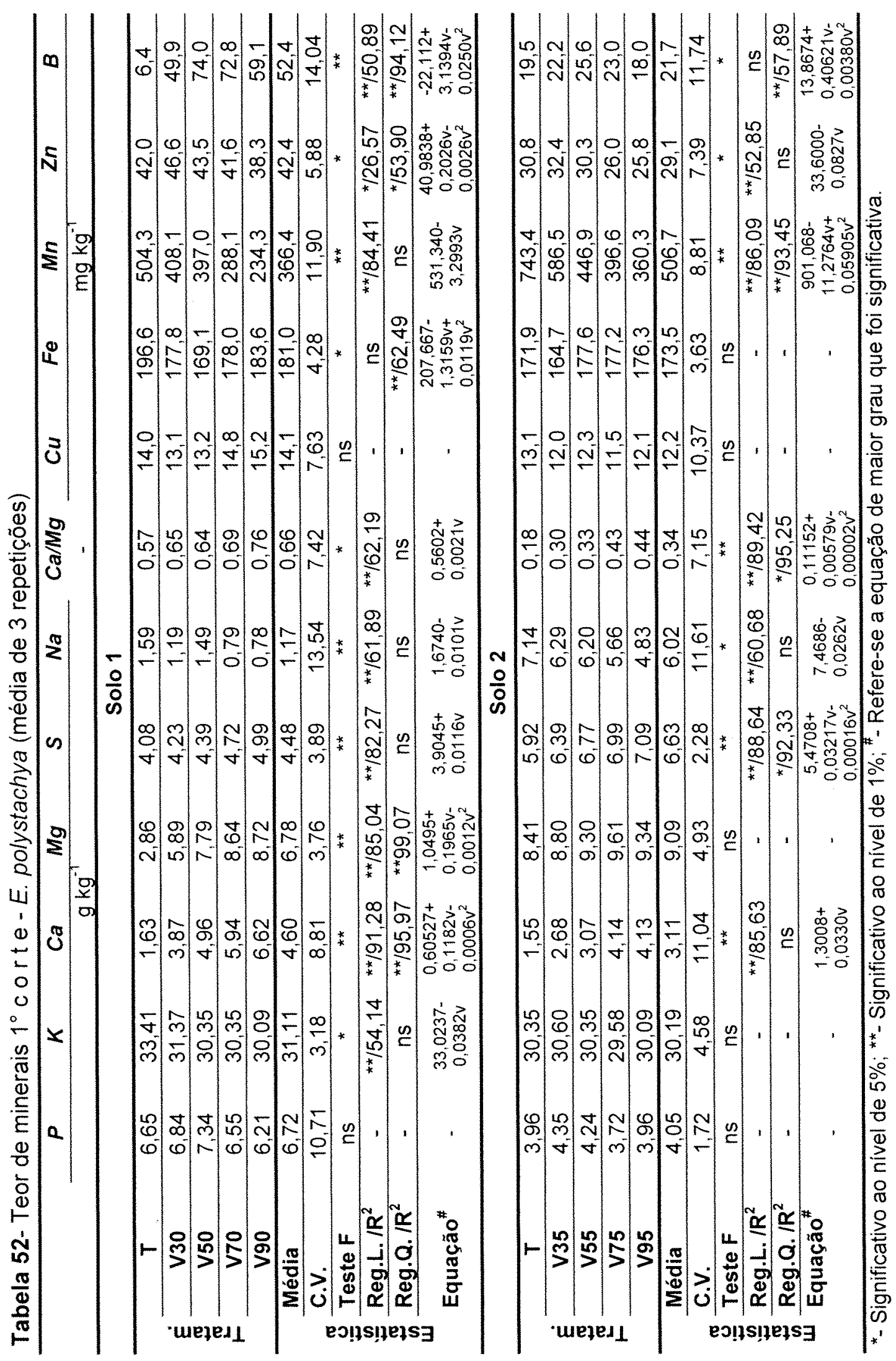




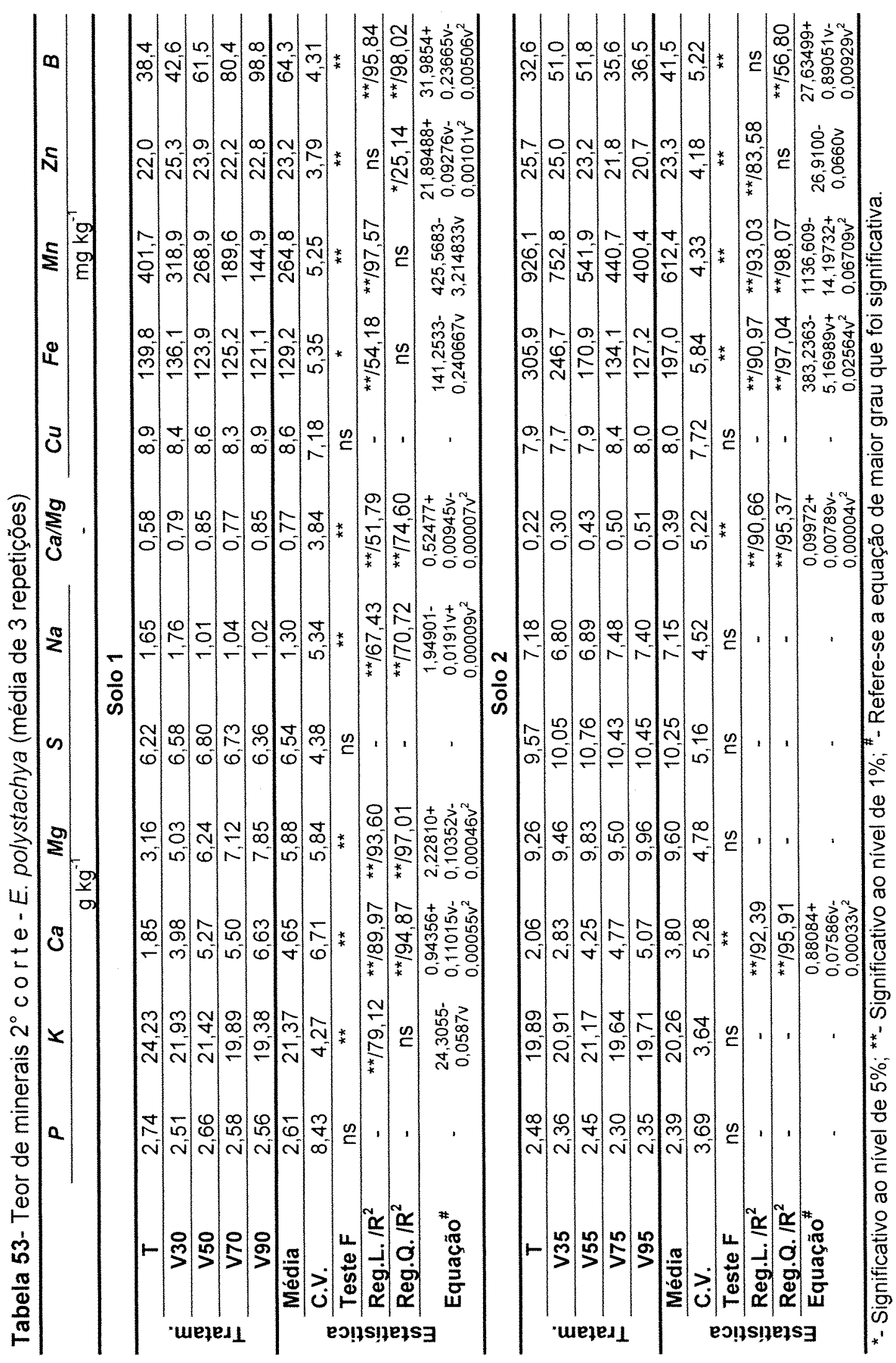




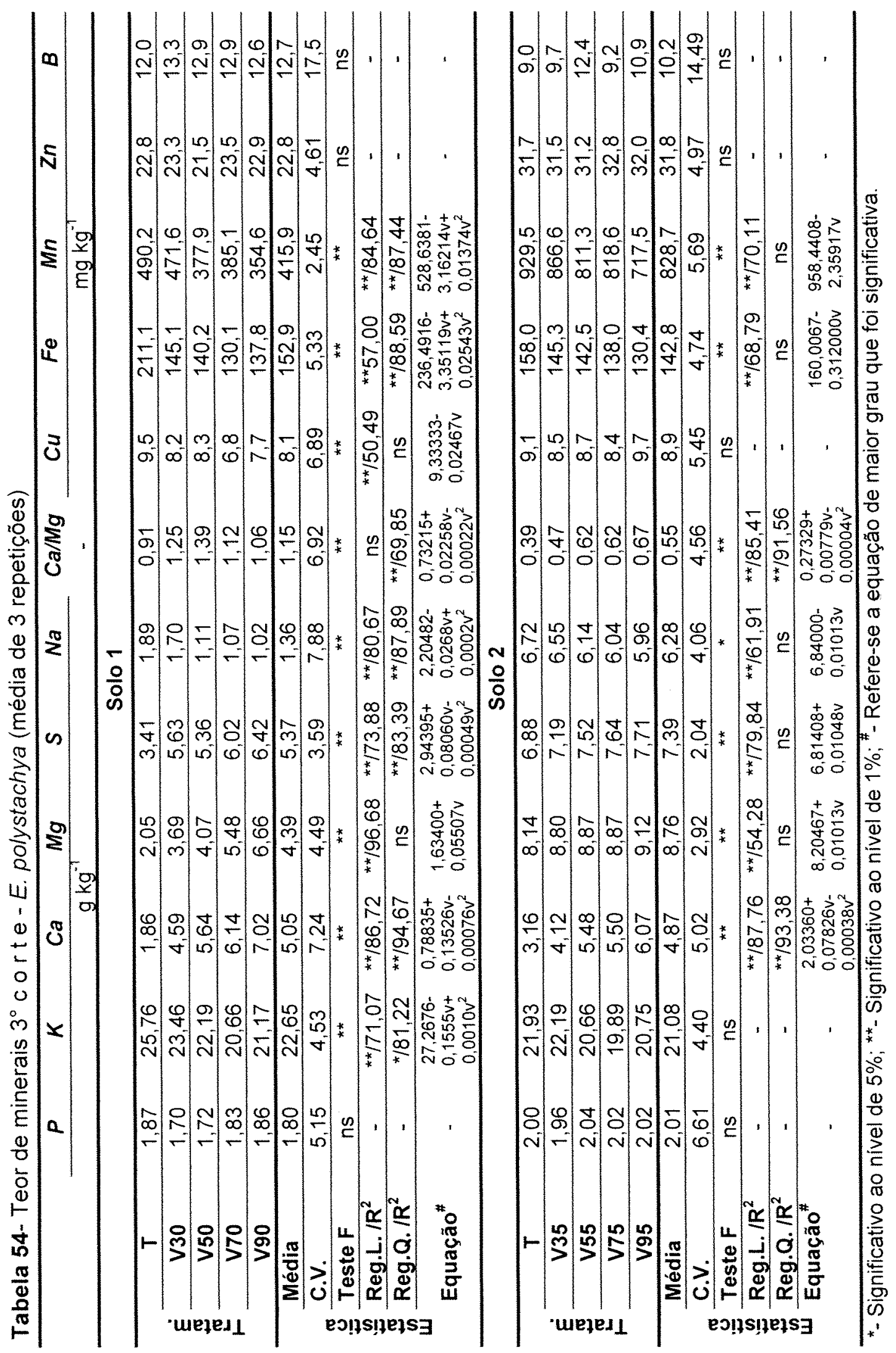




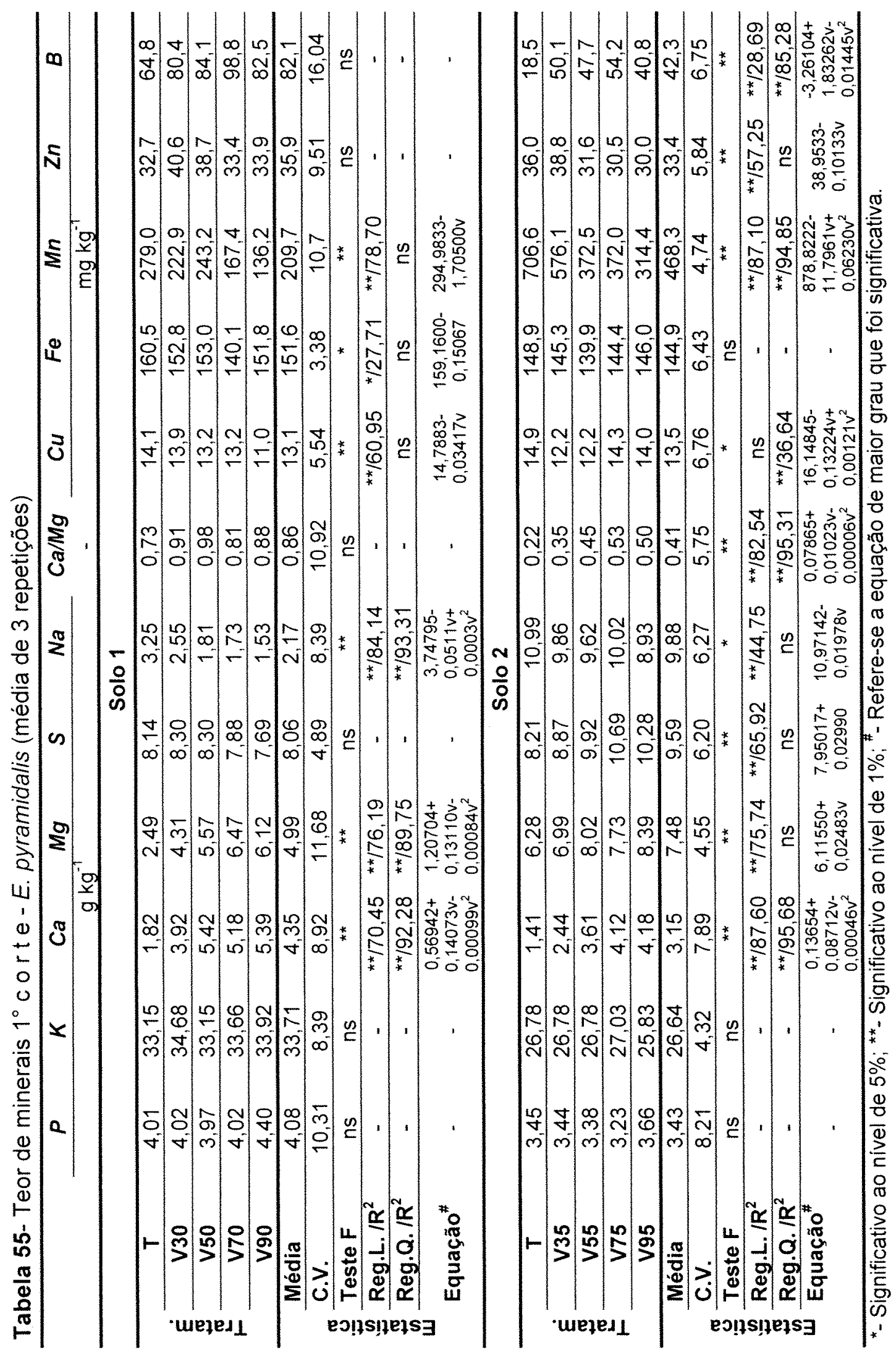




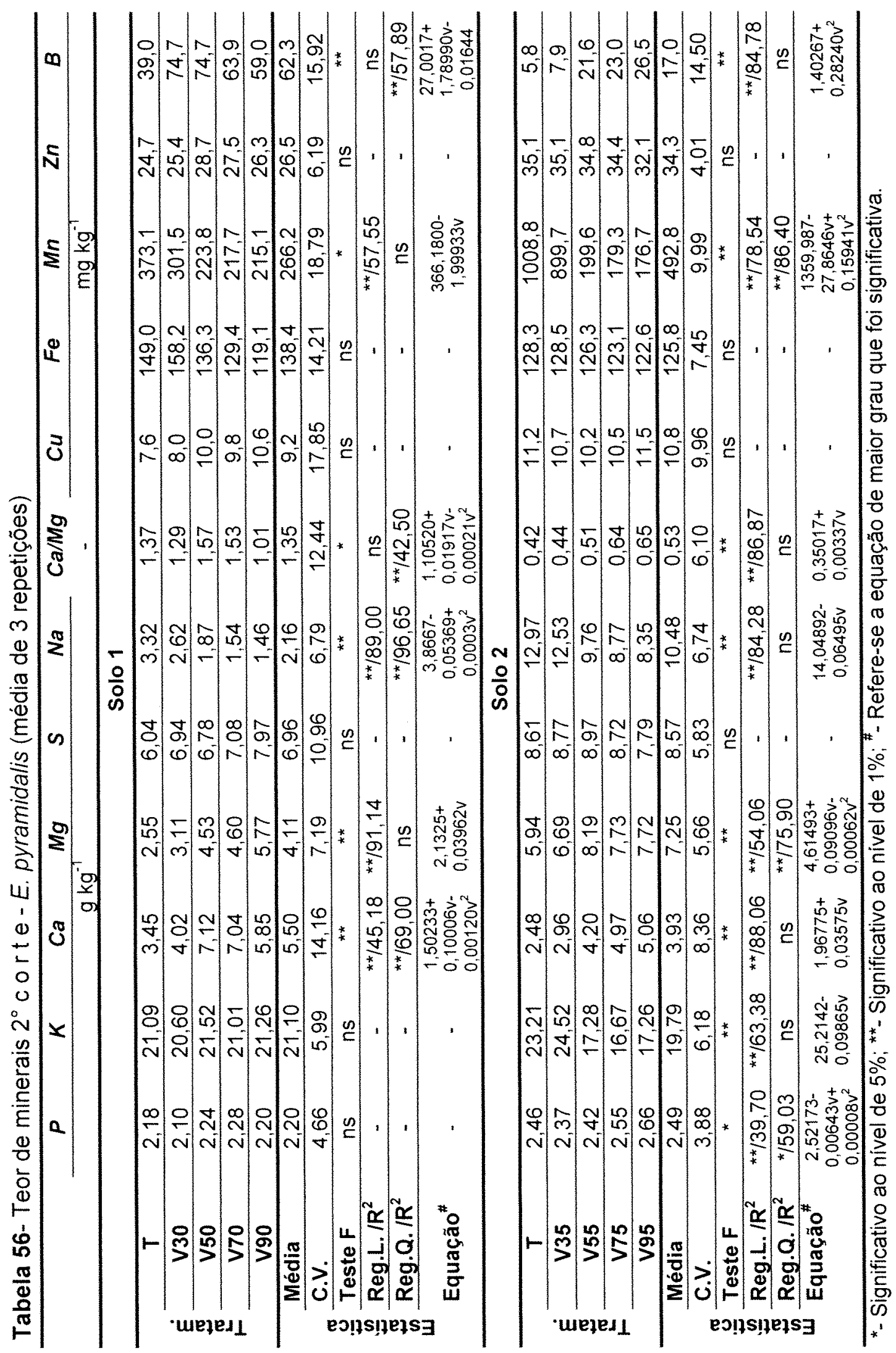




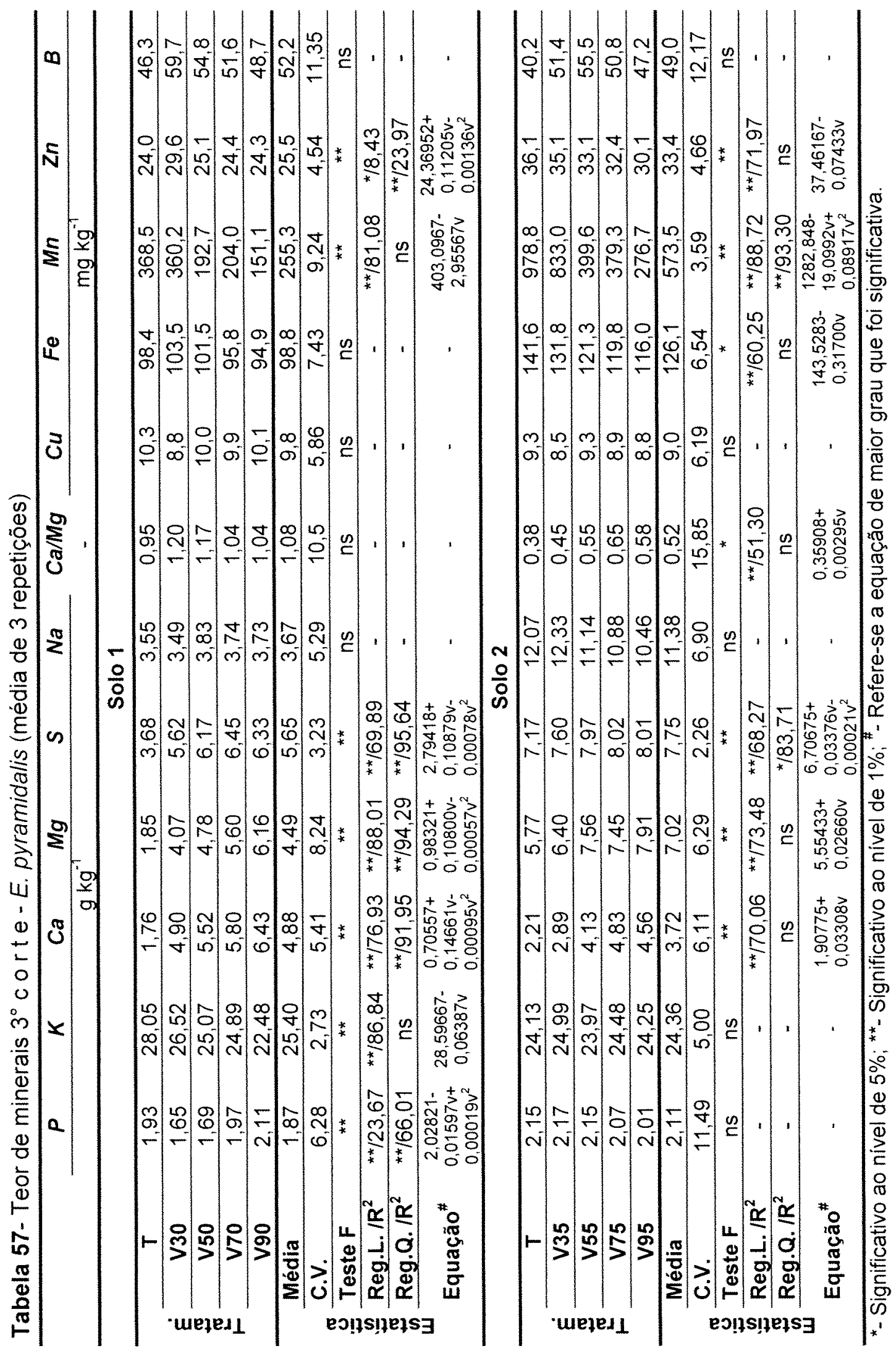




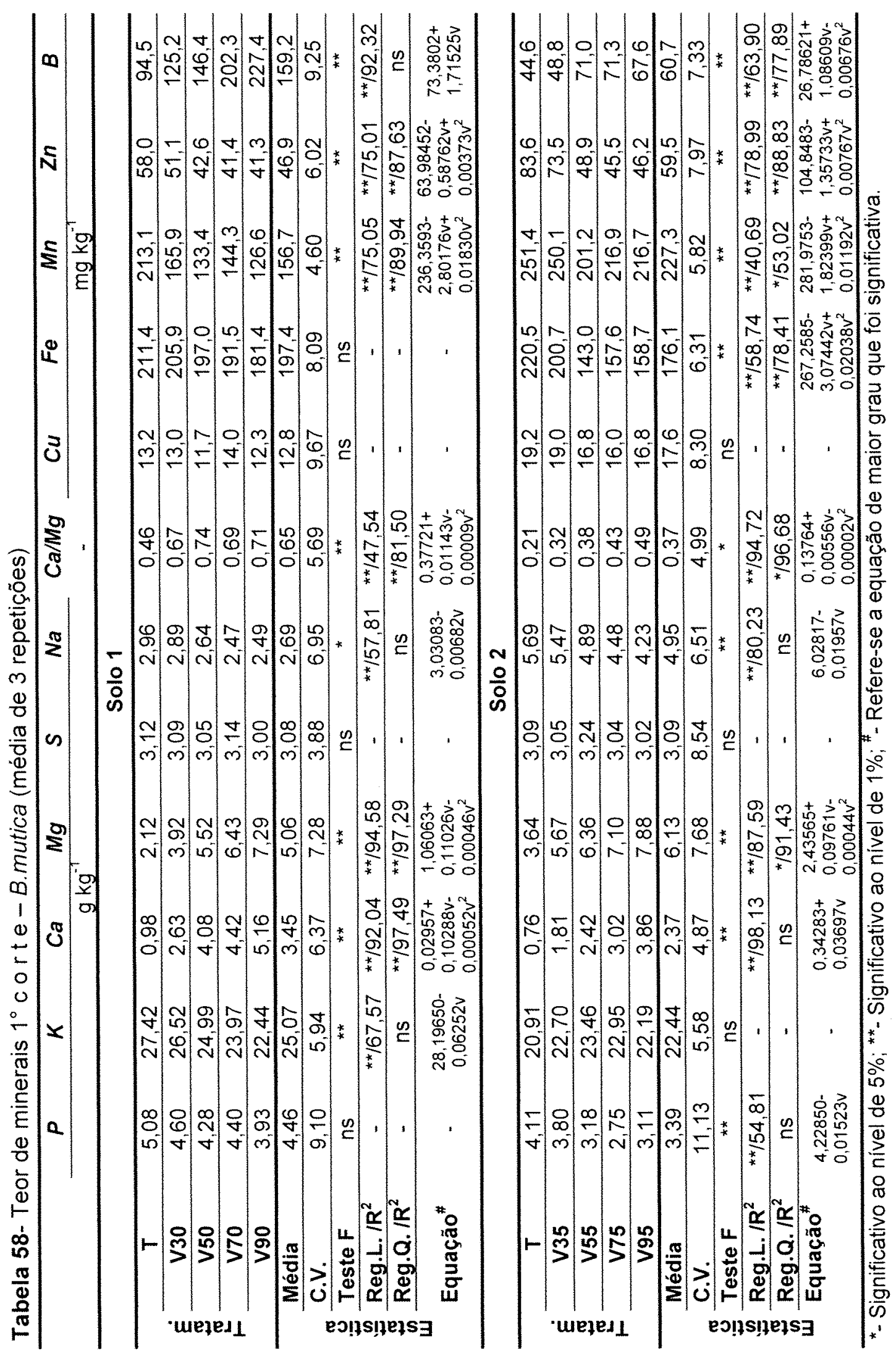




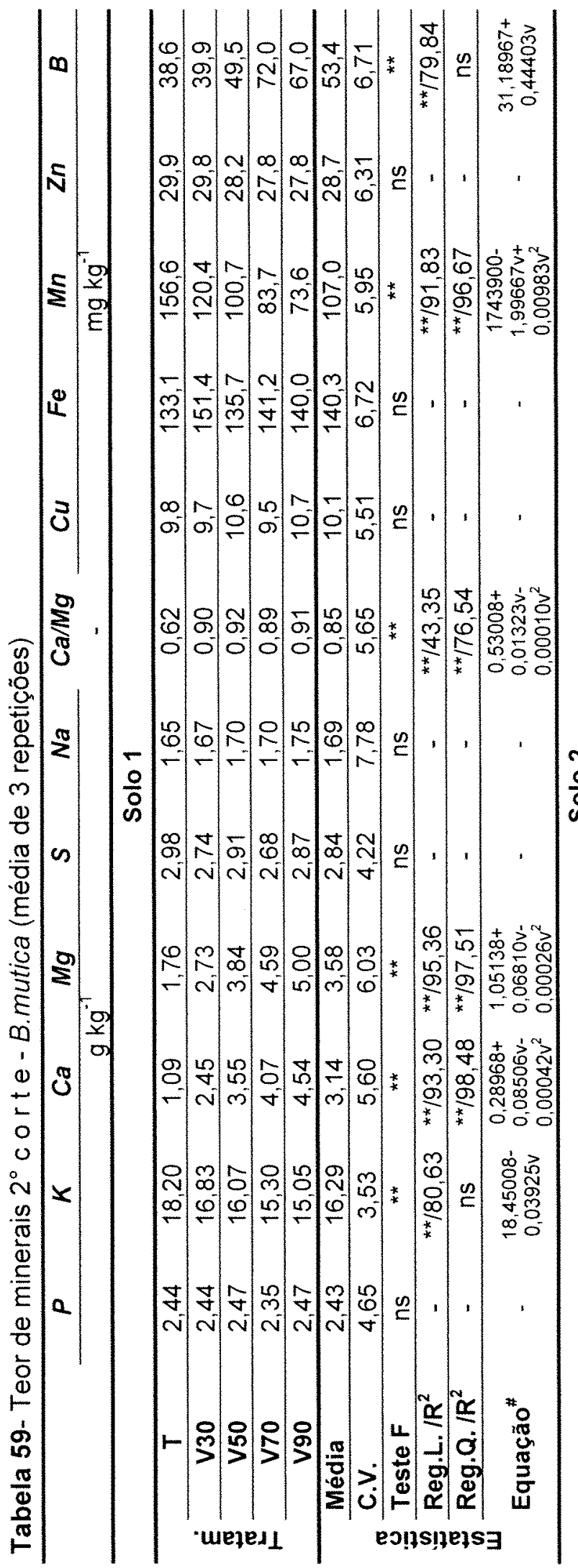

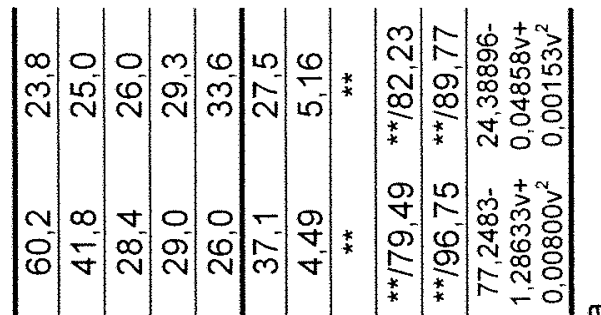

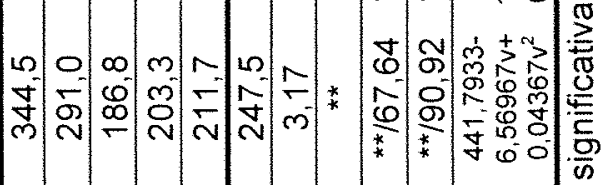

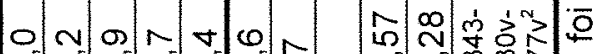

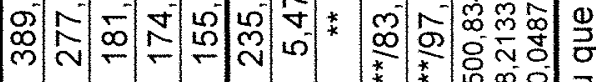

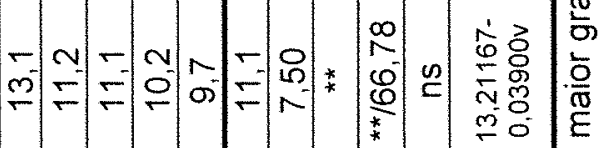

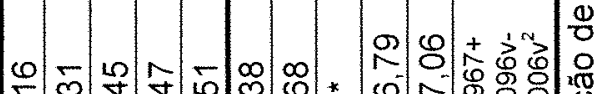
0. ***0;

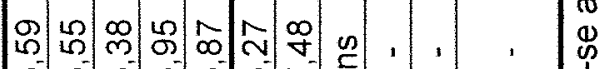
0 o 0 w \&

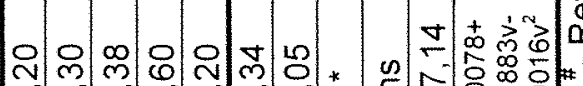

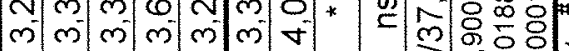

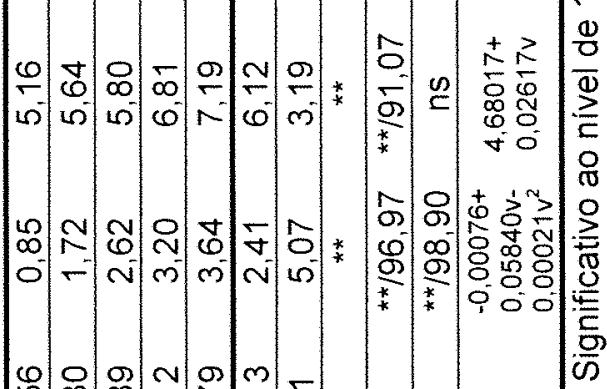

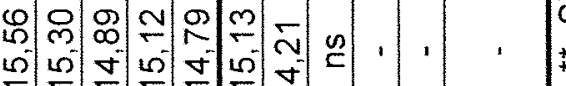
5)

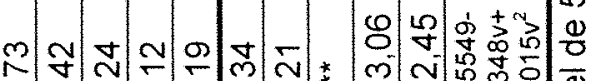

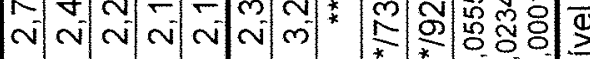

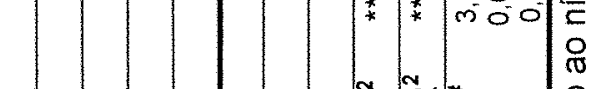

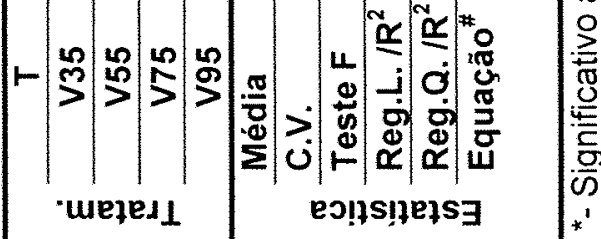




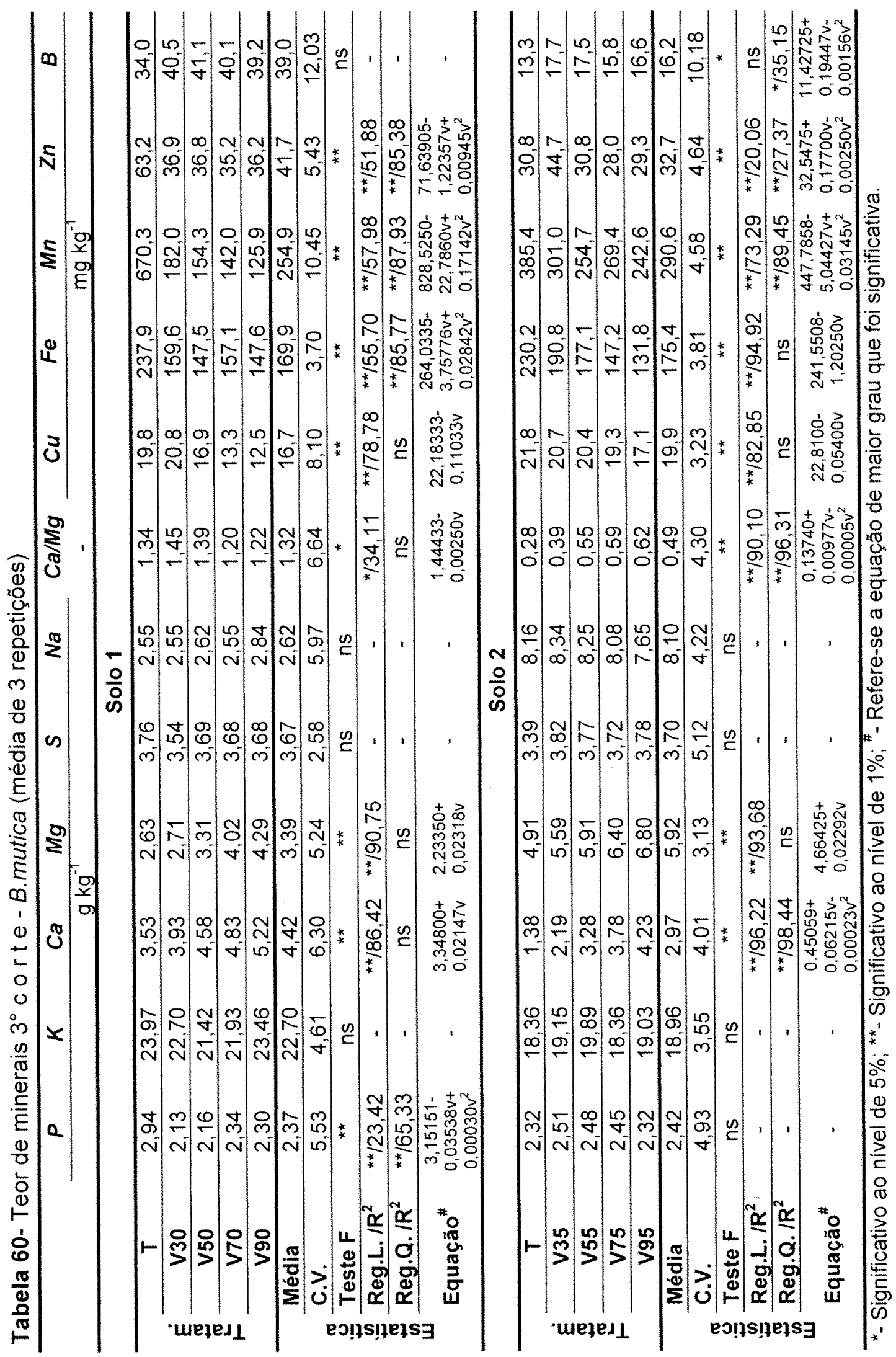




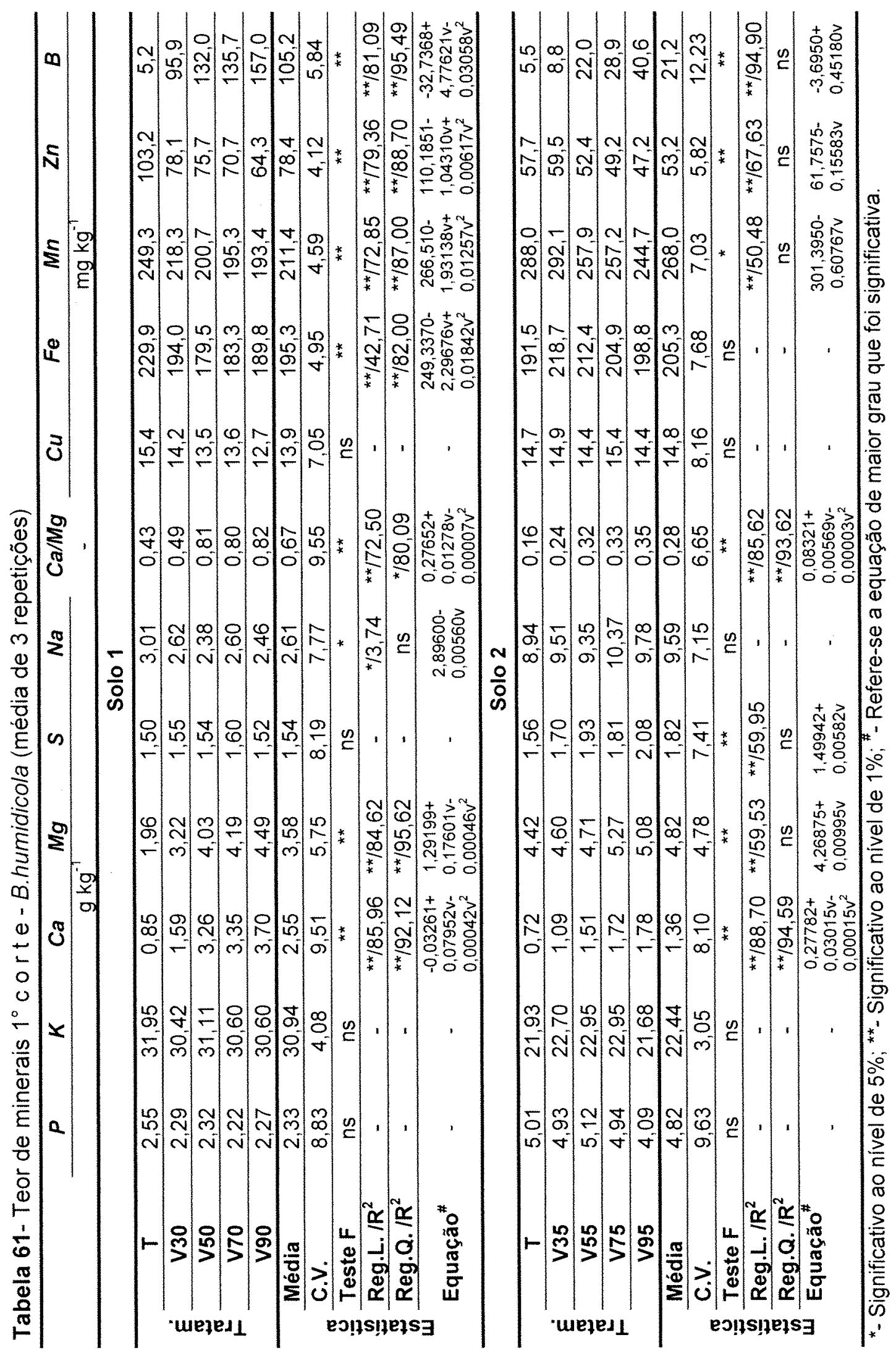




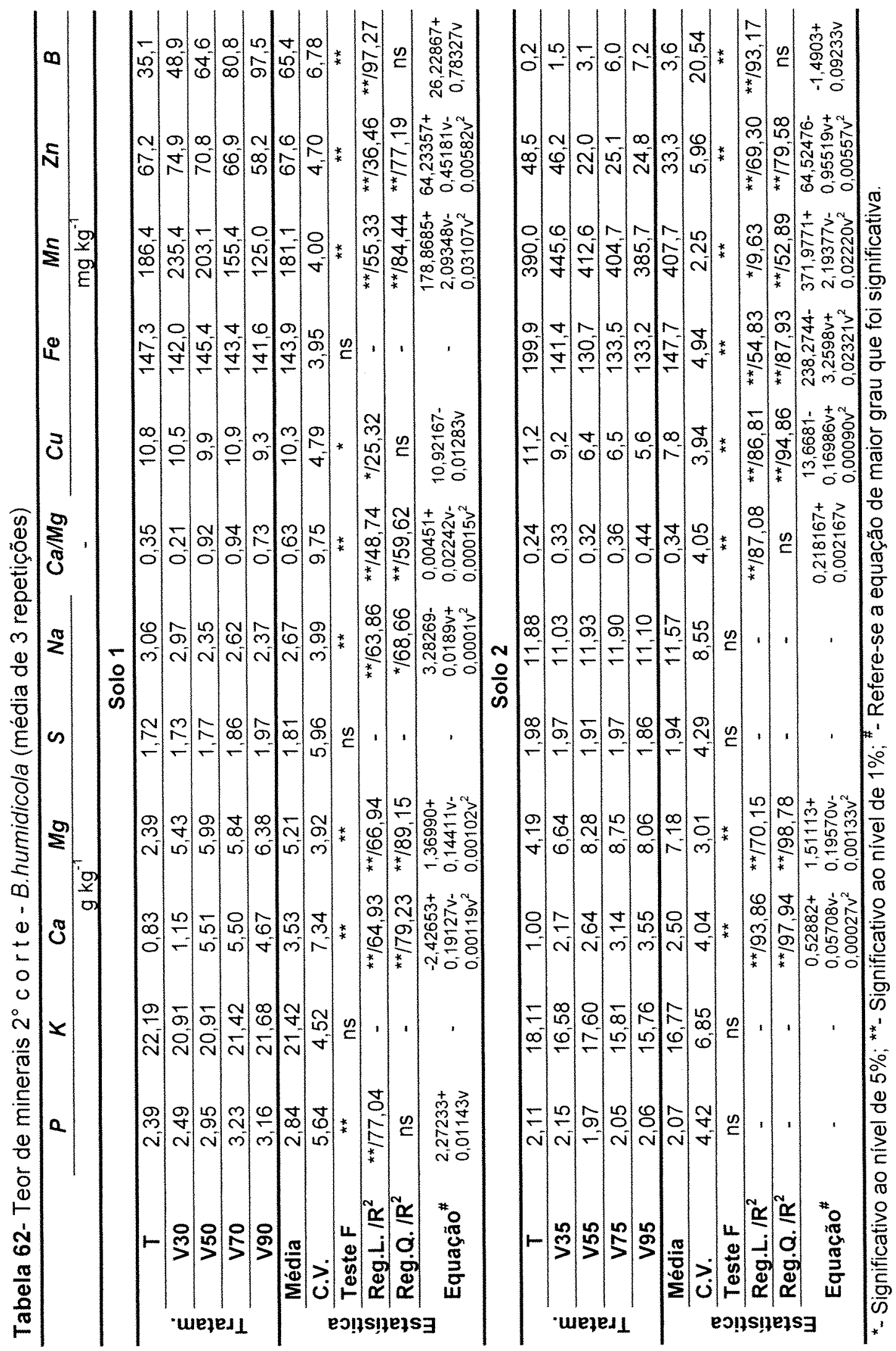




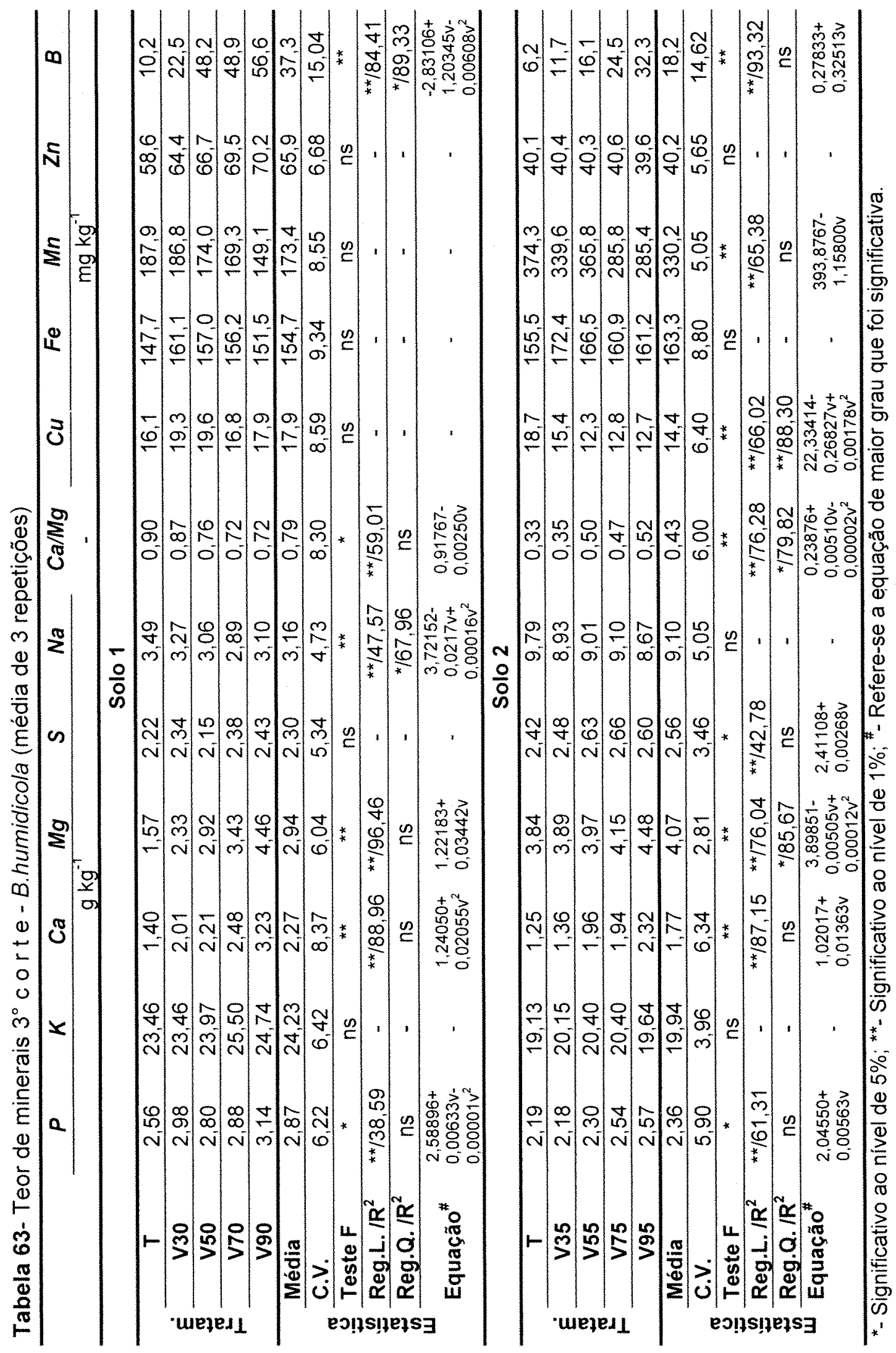




\subsection{ANÁLISE BRDMATLĹGICA}

Os resultados dos parâmetros analisados (Matéria mineral, Proteína Bruta, Fibra em detergente neutro, Fibra em detergente ácido, lignina e digestibilidade "in vitro" da matérica orgânica) estão apresentados nas Tabelas 64 a 71.

O comportamento dos teores de MM nas folhas das forrageiras tiveram um comportamento completamente distinto entre os solos e espécies. As espécies do gênero Echinochloa tiveram comportamento idêntico, quando cultivadas no solo1, tendo seus valores de MM sempre acrescidos com as doses crescentes de calcário, fenômeno este explicado por curvas quadráticas no primeiro corte e por modelos lineares no segundo e terceiro corte; quando cultivada no solo2, apresentaram no primeiro corte reduções nos teores de matéria mineral com o aumento da calagem, explicadas por modelos quadráticos e não apresentando efeito significativo nos demais cortes. As espécies do gênero Brachiaria também tiveram comportamento bem semelhante não demonstrando efeitos significativo para nenhum corte quando cultivadas no solo1, e apresentando reduções em 2 dos 3 corte realizados para a $B$. mutica e em apenas 1 corte para a $B$. humidicola, quando cultivadas no solo2.

Os aumento MM observado nas plantas cultivada no solo 1 podem ser explicados pelos aumentos altamente significativos nos teores de $\mathrm{Ca}$ e $\mathrm{Mg}$ ocorridos nos tecidos foliares. Como possível causa para a ocorrência na redução da MM no solo 2, tem-se que este solo já possuía naturalmente altos teores de $\mathrm{Mg}$, sendo inclusive em dois dos casos em que a MM foi significativa, os teores de Mg não o foram. Pode-se também observar que mesmo quando os teores de $\mathrm{Mg}$ foram significativos os acréscimos nos teores foram menores que para o solol, somando-se a menor elevação de $\mathrm{Mg}$ tem-se que este solo possuía elevadas concentrações de $\mathrm{Na}$ e que as plantas cultivadas nele também apresentaram elevadas concentrações deste elemento, que foram significativamente reduzidas pela calagem, de modo que os aumentos na concentração de Ca podem não ter compensado as reduções em $\mathrm{Na}$, causando desta forma uma redução geral da MM. Não 
se pode também descartar o efeito de diluição, já que com exceção da B. humidicola, em todas as vezes que foi verificado efeito de redução na MM este foi acompanhado pelo aumento de MSF. E ainda, alterações podem ter ocorrido nos teores de silício, já que sabidamente as gramíneas acumulam este elemento, não podendo se afirmar porém a participação deste no fenômeno pois os teores deste, como sabido, não foram analisados.

De forma geral, os teores de proteína bruta $(\mathrm{N}$ total $\times$ 6,25) não foram afetados pelas doses de calcário aplicadas ao solo em ambos os solos, pois dos 24 cortes realizados, em apenas 3 situações este parâmetro foi afetado significativamente. A nulidade de efeito para teores de nitrogênio está de acordo com resultados obtidos por Abruña \& Figarela (1957), Werner et al.(1979), Luz et al. (1999), Premazzi (1991) para a B. brizantha e por Mitidieri (1995), para o segundo corte realizado em 3 variedades de Panicum e B. brizantha e para os dois cortes do Andropogon.

Os efeitos significativos para PB foram observados em 2 ocasiões para a $B$. mutica, quando cultivada no solo2, onde apresentou redução nos teores com o aumento da saturação de bases, porém nestes mesmos cortes houve aumento do parâmetro MSF, altamente significativo no primeiro corte e apenas numérico no segundo corte, ou seja, possivelmente ocorreu o fenômeno de diluição do $\mathrm{N}$ com o aumento da produção, fenômeno este, também encontrado por Mitidieri (1995) e Gonçalves et al. (2000). Na outra ocasião em que foi verificado efeito significativo, este ocorreu com E. polystachya no primeiro corte, quando cultivada no solo1, mostrando mais uma vez o comportamento inverso entre MSF e PB, já que neste corte a MSF teve um comportamento quadrático com ponto de máxima e a $\mathrm{PB}$ um comportamento quadrático com ponto de mínima.

Os valores de FDN foram significativamente alterados em 9 dos 24 cortes realizados, em oito observações mostrando reduções com o aumento da doses de calcário e em apenas uma ocasião mostrando um efeito quadrático com ponto de máxima. Os teores de FDA mostraram o mesmo tipo de comportamento de redução em 5 ocasiões. Porém todas as ocorrências de significância estatística nos teores de FDN e/ou FDA ocorreram em situações onde os teores de MM também foram significativos, 
ou que pelo menos tiveram tendência numérica com comportamento justamente oposto ao das frações de fibra. Este comportamento mostra que a calagem mudou a partição dos constituintes do tecido foliar, quando houve aumento da fração mineral, pelo menos em parte, ocorreu redução de tecido fibroso. Os teores de lignina nas folhas não foram alterados significativamente em nenhuma espécie, cultivadas em ambos os solos. A não significância para os teores de FDA, FDN na maioria das oportunidades e a não significância em todos os casos para a lignina estão de acordo com trabalho realizado por Luz et al. (1999) o qual não verificou efeito significativo para estes parâmetros.

A digestibilidade foi praticamente indiferente aos tratamentos pois das 24 cortes realizados, somente em 2 ocasiões ocorrerem efeitos significativos, em um dos casos apresentando um modelo quadrático, mostrando um ponto de máximo na saturação de $59,64 \%$ que ocorreu no segundo Corte da E. polystachya cultivada no solo2 e ainda um modelo linear crescente para o $3^{\circ}$ corte da E. pyramidalis quando cultivada no solo1, tendo ambos os modelos coeficientes de determinação próximos de $50 \%$, o que mostra equações que pouco explicam o fenômeno. $\mathrm{E}$ ainda, do ponto de vista biológico, as diferenças encontradas de $2,03 \%$ e $2,92 \%$ entre o menor e maior valor observado, respectivamente para os dois casos citados, provavelmente não irão interferir no desempenho de ruminantes que estiverem pastando desta forragem. Luz et al. (1999) também não verificaram efeitos da calagem neste parâmetro. 
Tabela 64 - Análises bromatológicas E. polystachya cultivada no solo 01

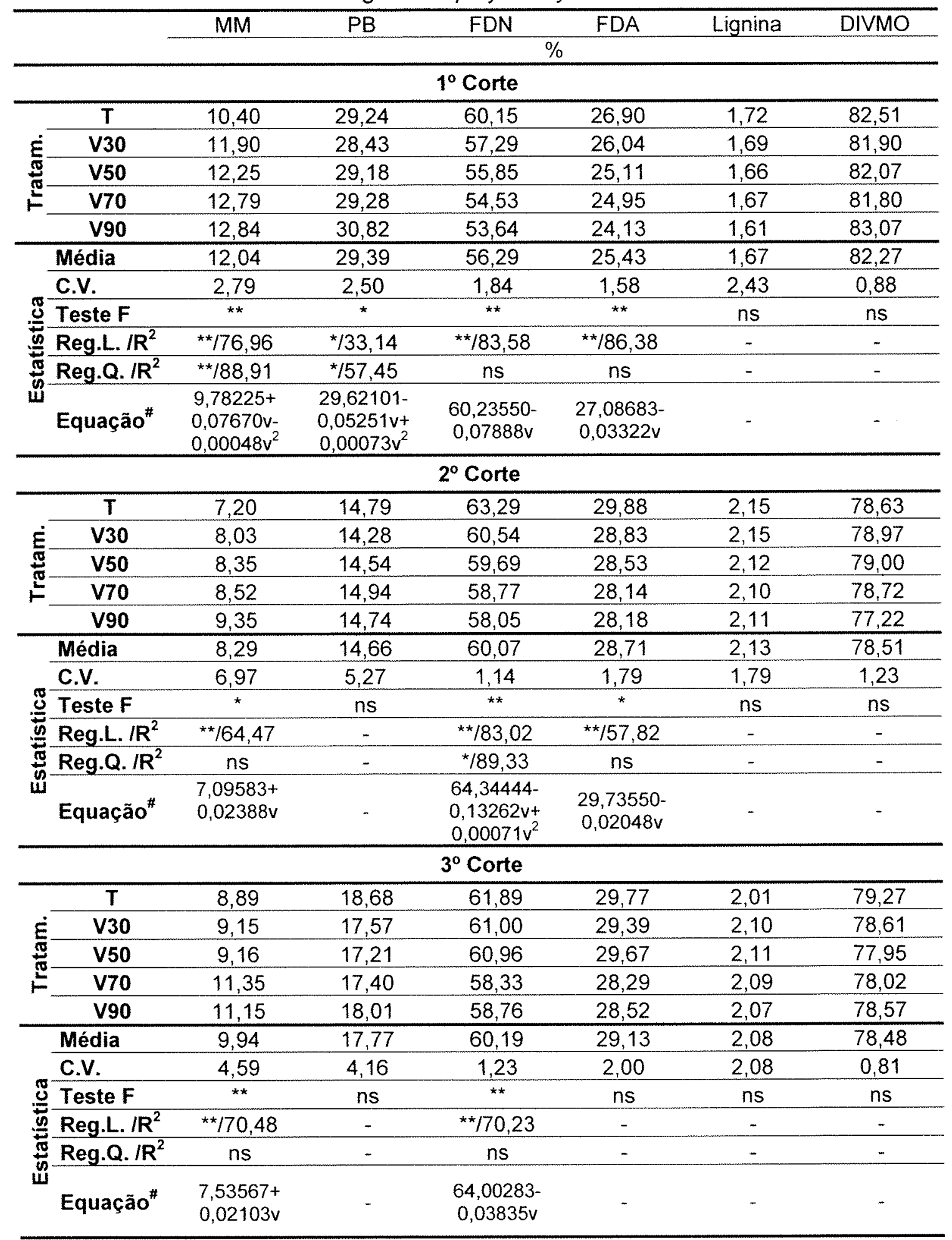

MM, PB, FDN, FDA e Lignina estāo expressos em base de matéria seca e DIVMO em base de matéria orgânica. 
Tabela 65 - Análises bromatológicas E. polystachya cultivada no solo 02

\begin{tabular}{|c|c|c|c|c|c|c|}
\hline & MM & PB & FDN & FDA & Lignina & DIVMO \\
\hline & \multicolumn{6}{|c|}{$\%$} \\
\hline \multicolumn{7}{|c|}{$1^{\circ}$ Corte } \\
\hline$T$ & 13,14 & 26,16 & 56,08 & 27,47 & 1,81 & 79,78 \\
\hline V30 & 13,14 & 27,55 & 55,01 & 26,94 & 1,75 & 81,00 \\
\hline V50 & 12,25 & 27,57 & 54,86 & 26,66 & 1,78 & 80,59 \\
\hline V70 & 12,44 & 27,69 & 53,92 & 26,23 & 1,77 & 80,54 \\
\hline V90 & 12,42 & 28,08 & 54,20 & 26,35 & 1,79 & 80,65 \\
\hline Média & 12,68 & 27,41 & 54,81 & 26,73 & 1,78 & 80,51 \\
\hline C.V. & 1,66 & 7,22 & 1,81 & 3,03 & 2,96 & 1,30 \\
\hline Teste F & ** & ns & $\mathrm{ns}$ & ns & ns & ns \\
\hline Reg.L. $/ R^{2}$ & ${ }^{* *} / 52,00$ & - & - & - & - & - \\
\hline$\frac{\pi}{0}$ Reg.Q. $/ R^{2}$ & $* / 60,69$ & - & - & - & - & - \\
\hline Equação" & $\begin{array}{l}13,68197- \\
0,03108 v+ \\
0,00019 v^{2} \\
\end{array}$ & - & - & - & - & - \\
\hline \multicolumn{7}{|c|}{$2^{\circ}$ Corte } \\
\hline$T$ & 11,69 & 15,53 & 60,06 & 29,80 & 2,18 & 77,16 \\
\hline V30 & 12,01 & 15,65 & 58,20 & 29,15 & 2,13 & 77,63 \\
\hline V50 & 11,75 & 16,39 & 57,78 & 28,48 & 2,07 & 78,73 \\
\hline V70 & 11,12 & 15,48 & 58,85 & 28,86 & 2,12 & 78,36 \\
\hline V90 & 11,23 & 15,41 & 58,27 & 28,94 & 2,15 & 77,48 \\
\hline Média & 11,56 & 15,69 & 58,63 & 29,05 & 2,13 & 77,87 \\
\hline C.V. & 4,78 & 3,75 & 1,65 & 1,69 & 1,71 & 0,70 \\
\hline Teste F & ns & ns & ns & $\mathrm{ns}$ & $\mathrm{ns}$ & * \\
\hline Reg.L. IR ${ }^{2}$ & - & - & - & - & - & ns \\
\hline 总 Reg.Q. $/ R^{2}$ & - & - & - & - & - & $\star \star \star / 53,23$ \\
\hline Equação\# & - & - & - & - & - & $\begin{array}{l}75,83833+ \\
0,08875 v- \\
0,00074 v^{2} \\
\end{array}$ \\
\hline \multicolumn{7}{|c|}{$3^{\circ}$ Corte } \\
\hline $\mathbf{T}$ & 11,35 & 19,32 & 58,33 & 28,29 & 2,01 & 78,93 \\
\hline V30 & 11,15 & 18,68 & 58,76 & 28,52 & 2,06 & 78,19 \\
\hline V50 & 11,43 & 19,21 & 57,39 & 28,00 & 2,02 & 78,53 \\
\hline V70 & 10,84 & 19,05 & 57,58 & 27,90 & 1,99 & 79,66 \\
\hline V90 & 10,90 & 18,95 & 57,92 & 28,16 & 2,01 & 79,41 \\
\hline Média & 11,13 & 19,04 & 58,00 & 28,17 & 2,02 & 78,94 \\
\hline C.V. & 2,71 & 4,70 & 1,58 & 1,70 & 2,21 & 0,85 \\
\hline Teste F & ns & ns & ns & ns & ns & ns \\
\hline Reg.L. IR & - & - & - & - & - & - \\
\hline$\overbrace{\tilde{W}}^{\mathbb{N}}$ Reg.Q. $/ R^{2}$ & - & - & - & - & - & - \\
\hline Equação" & - & - & - & - & - & - \\
\hline
\end{tabular}

MM, PB, FDN, FDA e Lignina estão expressos em base de matéria seca e DIVMO em base de matéria orgânica. 
Tabela 66 - Análises bromatológicas E. pyramidalis cultivada no solo 01

\begin{tabular}{|c|c|c|c|c|c|c|c|}
\hline & & $\mathrm{MM}$ & $\mathrm{PB}$ & FDN & FDA & Lignina & DIVMO \\
\hline & & \multicolumn{6}{|c|}{$\%$} \\
\hline \multicolumn{8}{|c|}{$1^{\circ}$ Corte } \\
\hline \multirow{5}{*}{ 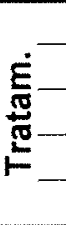 } & $T$ & 10,96 & 25,78 & 59,38 & 25,97 & 1,66 & 84,43 \\
\hline & V30 & 11,66 & 27,41 & 57,62 & 25,54 & 1,63 & 85,94 \\
\hline & V50 & 11,80 & 27,75 & 55,96 & 24,82 & 1,61 & 86,40 \\
\hline & V70 & 11,81 & 27,27 & 55,70 & 24,75 & 1,65 & 85,91 \\
\hline & V90 & 11,61 & 27,76 & 55,66 & 24,80 & 1,64 & 86,66 \\
\hline & Média & 11,57 & 27,19 & 56,86 & 25,18 & 1,64 & 85,87 \\
\hline & C.V. & 2,49 & 6,64 & 1,40 & 2,13 & 2,84 & 1,29 \\
\hline & Teste F & * & ns & $* *$ & ns & ns & ns \\
\hline & Reg.L. / $\mathbf{R}^{2}$ & $* / 27,08$ & - & $\star * / 69,27$ & - & - & - \\
\hline & Reg.Q. $/ R^{2}$ & ${ }^{*} / 61,90$ & - & $* / 82,49$ & - & - & - \\
\hline & Equação\# & $\begin{array}{l}10,61725+ \\
0,04180 v- \\
0,00035 v^{2} \\
\end{array}$ & - & $\begin{array}{l}60,67344- \\
0,13315 \mathrm{v}^{+} \\
0,00086 \mathrm{v}^{2} \\
\end{array}$ & - & - & - \\
\hline \multicolumn{8}{|c|}{$2^{\circ}$ Corte } \\
\hline \multirow{5}{*}{ 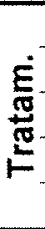 } & $T$ & 8,53 & 19,35 & 63,61 & 28,96 & 1,97 & 81,49 \\
\hline & V30 & 9,91 & 20,46 & 60,36 & 27,96 & 1,93 & 83,32 \\
\hline & V50 & 10,07 & 19,83 & 59,61 & 27,78 & 1,96 & 82,93 \\
\hline & V70 & 10,62 & 20,81 & 57,87 & 27,31 & 1,90 & 83,97 \\
\hline & V90 & 11,18 & 22,01 & 55,42 & 26,05 & 1,82 & 84,11 \\
\hline \multirow{6}{*}{ 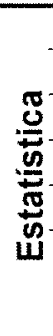 } & Média & 10,06 & 20,49 & 59,37 & 27,61 & 1,92 & 83,16 \\
\hline & C.V. & 5,60 & 7,10 & 2,45 & 2,71 & 3,62 & \\
\hline & Teste F & $* *$ & $\mathrm{~ns}$ & $* *$ & ** & ns & ns \\
\hline & Reg.L. $/ R^{2}$ & $* * / 72,34$ & - & $* * / 81,04$ & $* * / 65,90$ & - & - \\
\hline & Reg.Q. $/ R^{2}$ & ns & - & ns & ns & - & - \\
\hline & Equação\# & $\begin{array}{l}8,56100+ \\
0,03003 v\end{array}$ & - & $\begin{array}{l}64,08833- \\
0,09430 \mathrm{v}\end{array}$ & $\begin{array}{c}29,22867- \\
0,03240 \mathrm{v}\end{array}$ & - & - \\
\hline \multicolumn{8}{|c|}{$3^{\circ}$ Corte } \\
\hline \multirow{5}{*}{ 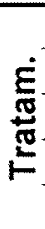 } & $\mathrm{T}$ & 8,69 & 20,89 & 65,93 & 30,37 & 2,06 & 80,02 \\
\hline & V30 & 9,53 & 21,62 & 62,38 & 29,10 & 1,99 & 81,10 \\
\hline & V50 & 9,55 & 20,69 & 62,22 & 29,12 & 2,01 & 82,24 \\
\hline & V70 & 10,16 & 20,37 & 61,08 & 28,98 & 2,03 & 81,36 \\
\hline & V90 & 10,14 & 20,43 & 60,09 & 28,41 & 1,98 & 82,36 \\
\hline \multirow{6}{*}{ 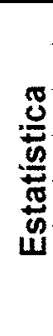 } & Média & 9,61 & 20,80 & 62,34 & 29,20 & 2,01 & 81,42 \\
\hline & C.V. & 3,62 & 3,05 & 0,59 & 1,30 & 1,50 & 0,82 \\
\hline & Teste F & $* \star$ & ns & $\star \star \star$ & $* *$ & ns & $\star \star$ \\
\hline & Reg.L. $/ \mathbf{R}^{2}$ & $* \star / 67,62$ & - & $\star \star / 84,12$ & $* * / 64,02$ & - & $\star \star / 47,75$ \\
\hline & Reg.Q. $/ \mathrm{R}^{2}$ & ns & - & ${ }^{* *} / 90,22$ & ns & - & ns \\
\hline & Equação" & $\begin{array}{l}8,73283+ \\
0,01765 \mathrm{v}\end{array}$ & - & $\begin{array}{l}66,83861- \\
0,13875 v+ \\
0,00074 v^{2}\end{array}$ & $\begin{array}{l}30,20367 \\
0,02017 v\end{array}$ & - & $\begin{array}{c}80,17950+ \\
0,02472 v\end{array}$ \\
\hline
\end{tabular}

MM, PB, FDN, FDA e Lignina estão expressos em base de matéria seca e DIVMO em base de matéria orgânica. 
Tabela 67 - Análises bromatológicas E. pyramidalis cultivada no solo 02

\begin{tabular}{|c|c|c|c|c|c|c|c|}
\hline & & $\mathrm{MM}$ & PB & FDN & FDA & Lignina & DIVMS \\
\hline & & \multicolumn{6}{|c|}{$\%$} \\
\hline \multicolumn{8}{|c|}{$1^{\circ}$ Corte } \\
\hline \multirow{5}{*}{$\sum^{\frac{E}{0}}$} & $\mathrm{~T}$ & 13,60 & 24,47 & 55,28 & 23,44 & 1,72 & 84,89 \\
\hline & V30 & 12,83 & 25,82 & 55,65 & 23,76 & 1,71 & 85,36 \\
\hline & V50 & 12,60 & 24,21 & 54,82 & 23,62 & 1,72 & 84,93 \\
\hline & V70 & 12,42 & 25,77 & 55,05 & 23,45 & 1,71 & 85,98 \\
\hline & V90 & 12,72 & 27,85 & 53,82 & 22,98 & 1,66 & 87,40 \\
\hline \multirow{6}{*}{ 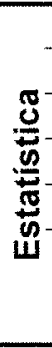 } & Média & 12,83 & 25,62 & 54,92 & 23,45 & 1,70 & 85,71 \\
\hline & C.V. & 2,64 & 7,08 & 1,54 & 1,58 & 3,01 & 1,16 \\
\hline & Teste F & $*$ & ns & ns & ns & ns & ns \\
\hline & Reg.L. $/ R^{2}$ & $* * / 39,41$ & - & - & - & - & - \\
\hline & Reg.Q. $/ R^{2}$ & $* / 67,40$ & - & - & - & - & - \\
\hline & Equação & $\begin{array}{c}14,30440- \\
0,05384 v+ \\
0,00039 v^{2}\end{array}$ & - & - & - & - & - \\
\hline \multicolumn{8}{|c|}{$2^{\circ}$ Corte } \\
\hline \multirow{5}{*}{ 懢 } & $\mathrm{T}$ & 12,32 & 14,39 & 59,40 & 27,70 & 2,08 & 79,63 \\
\hline & $\mathrm{V} 30$ & 12,08 & 15,33 & 58,66 & 27,14 & 2,07 & 80,17 \\
\hline & V50 & 12,46 & 15,84 & 57,94 & 27,37 & 2,05 & 81,12 \\
\hline & V70 & 12,31 & 15,77 & 57,87 & 27,21 & 2,05 & 80,66 \\
\hline & V90 & 12,09 & 16,02 & 57,04 & 26,69 & 2,00 & 82,14 \\
\hline \multirow{6}{*}{ 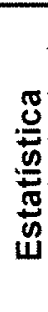 } & Média & 12,25 & 15,47 & 58,18 & 27,22 & 2,05 & 80,74 \\
\hline & C.V. & 3,82 & 8,02 & 1,71 & 2,45 & 3,10 & 1,95 \\
\hline & Teste F & ns & ns & ns & ns & ns & ns \\
\hline & Reg.L. $/ R^{2}$ & - & - & - & - & - & - \\
\hline & Reg.Q. $/ R^{2}$ & - & - & - & - & - & - \\
\hline & Equação & - & - & - & - & - & - \\
\hline \multicolumn{8}{|c|}{$3^{\circ}$ Corte } \\
\hline \multirow{5}{*}{ 离 } & $T$ & 12,20 & 22,32 & 60,51 & 28,76 & 1,95 & 83,33 \\
\hline & V30 & 11,78 & 22,55 & 60,34 & 28,89 & 1,96 & 83,31 \\
\hline & V50 & 12,24 & 21,51 & 59,38 & 28,84 & 1,99 & 83,35 \\
\hline & V70 & 12,40 & 21,89 & 58,33 & 27,86 & 1,97 & 83,60 \\
\hline & V90 & 11,63 & 20,60 & 60,40 & 29,45 & 2,07 & 83,06 \\
\hline \multirow{6}{*}{ 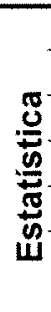 } & Média & 12,05 & 21,77 & 59,79 & 28,76 & 1,99 & 83,33 \\
\hline & C.V. & 3,97 & 4,65 & 1,66 & 1,94 & 1,53 & 0,74 \\
\hline & Teste F & ns & ns & ns & ns & ns & ns \\
\hline & Reg.L./R ${ }^{2}$ & - & - & - & - & - & - \\
\hline & Reg.Q. $/ R^{2}$ & - & - & - & - & - & - \\
\hline & Equação & - & - & - & - & - & - \\
\hline
\end{tabular}

MM, PB, FDN, FDA e Lignina estão expressos em base de matéria seca e DIVMO em base de matéria orgânica. 
Tabela 68 - Análises bromatológicas B. mutica cultivada no solo 01

\begin{tabular}{|c|c|c|c|c|c|c|}
\hline & MM & PB & FDN & FDA & Lignina & DIVMO \\
\hline & \multicolumn{6}{|c|}{$\%$} \\
\hline \multicolumn{7}{|c|}{$1^{\circ}$ Corte } \\
\hline $\mathrm{T}$ & 9,52 & 29,82 & 51,96 & 23,08 & 1,63 & 82,87 \\
\hline V30 & 9,51 & 28,42 & 52,27 & 22,94 & 1,64 & 83,13 \\
\hline V50 & 9,23 & 28,95 & 51,51 & 22,59 & 1,63 & 83,41 \\
\hline V70 & 9,80 & 30,98 & 49,57 & 22,27 & 1,60 & 84,57 \\
\hline V90 & 9,25 & 29,79 & 51,01 & 22,50 & 1,61 & 84,83 \\
\hline Média & 9,46 & 29,59 & 51,26 & 22,68 & 1,62 & 83,76 \\
\hline C.V. & 5,14 & 4,37 & 2,63 & 1,82 & 2,92 & 1,44 \\
\hline Teste F & ns & ns & ns & ns & ns & ns \\
\hline Reg.L. $/ R^{2}$ & - & - & - & - & - & - \\
\hline $\mathbb{H}_{\omega}$ Reg.Q. $/ R^{2}$ & - & - & - & - & - & - \\
\hline Equação" & - & - & - & - & - & - \\
\hline \multicolumn{7}{|c|}{$2^{\circ}$ Corte } \\
\hline$T$ & 5,28 & 21,52 & 58,92 & 25,06 & 1,77 & 82,97 \\
\hline V30 & 5,65 & 21,02 & 57,57 & 24,63 & 1,76 & 83,31 \\
\hline V50 & 5,84 & 22,50 & 56,27 & 24,03 & 1,73 & 84,09 \\
\hline V70 & 6,41 & 21,90 & 55,05 & 23,77 & 1,72 & 83,52 \\
\hline V90 & 6,01 & 22,21 & 55,96 & 24,29 & 1,78 & 82,90 \\
\hline Média & 5,84 & 21,83 & 56,75 & 24,36 & 1,75 & 83,36 \\
\hline C.V. & 8,21 & 3,87 & 2,23 & 3,00 & 2,38 & 1,13 \\
\hline J Teste F & ns & ns & * & ns & $\mathrm{ns}$ & ns \\
\hline Reg.L. $/ R^{2}$ & - & - & $* * / 49,17$ & - & - & - \\
\hline Reg.Q. $/ R^{2}$ & - & - & ns & - & - & - \\
\hline Equação & - & - & $\begin{array}{l}58,86000 \\
0,04213 v\end{array}$ & - & - & - \\
\hline \multicolumn{7}{|c|}{$3^{\circ}$ Corte } \\
\hline$T$ & 6,84 & 21,10 & 56,74 & 24,34 & 1,75 & 79,38 \\
\hline V30 & 7,17 & 23,87 & 58,95 & 25,98 & 1,74 & 80,49 \\
\hline V50 & 7,24 & 24,31 & 58,34 & 25,82 & 1,71 & 80,91 \\
\hline V70 & 7,39 & 23,05 & 57,10 & 24,85 & 1,69 & 81,00 \\
\hline V90 & 7,98 & 23,53 & 56,05 & 25,20 & 1,68 & 79,79 \\
\hline Média & 7,32 & 23,17 & 57,44 & 25,24 & 1,73 & 80,31 \\
\hline C.V. & 7,06 & 4,18 & 2,28 & 1,98 & 3,05 & 1,28 \\
\hline Teste F & ns & $\star \star *$ & ns & ns & - & ns \\
\hline Reg.L. $/ R^{2}$ & - & * & - & - & - & - \\
\hline Reg.Q. $/ R^{2}$ & - & ${ }^{* \star} / 47,69$ & - & - & - & - \\
\hline Equação" & - & $\begin{array}{c}20,24950+ \\
0,13270 \mathrm{v}- \\
0,00113 \mathrm{v}^{2}\end{array}$ & - & - & - & - \\
\hline
\end{tabular}

MM, PB, FDN, FDA e Lignina estão expressos em base de matéria seca e DIVMO em base de matéria orgânica. 
Tabela 69 - Análises bromatológicas $B$. mutica cultivada no solo 2

\begin{tabular}{|c|c|c|c|c|c|c|c|}
\hline & & MM & PB & FDN & FDA & Lignina & DIVMO \\
\hline & & \multicolumn{6}{|c|}{$\%$} \\
\hline \multicolumn{8}{|c|}{$1^{\circ}$ Corte } \\
\hline \multirow{5}{*}{ 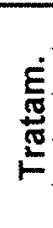 } & $T$ & 10,08 & 32,61 & 51,25 & 21,10 & 1,69 & 84,39 \\
\hline & V30 & 9,49 & 30,62 & 54,78 & 22,29 & 1,67 & 86,20 \\
\hline & V50 & 9,15 & 28,69 & 55,32 & 22,58 & 1,66 & 85,36 \\
\hline & v70 & 9,26 & 27,50 & 54,44 & 22,71 & 1,67 & 84,12 \\
\hline & V90 & 9,69 & 28,62 & 52,65 & 22,22 & 1,68 & 84,81 \\
\hline \multirow{6}{*}{ 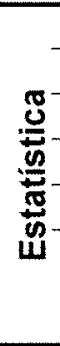 } & Média & 9,53 & 29,61 & 53,69 & 22,18 & 1,67 & 84,98 \\
\hline & C.V. & 2,70 & 5,41 & 1,41 & 2,78 & 2,38 & 1,38 \\
\hline & Teste F & $\star * *$ & * & $\star *$ & ns & ns & ns \\
\hline & Reg.L. $/ \mathbf{R}^{2}$ & ns & $\star \star / 48,72$ & ns & - & - & - \\
\hline & Reg.Q. $/ \mathrm{R}^{2}$ & $* \star / 70,80$ & ns & $\star \star / 82,37$ & - & - & - \\
\hline & Equação\# & $\begin{array}{l}10,79419 \\
0,05375 \mathrm{v}+ \\
0,00044 \mathrm{v}^{2} \\
\end{array}$ & $\begin{array}{c}32,55317- \\
0,05403 v\end{array}$ & $\begin{array}{c}48,21758+ \\
0,24941 \mathrm{v}- \\
0,00216 \\
\end{array}$ & - & - & - \\
\hline \multicolumn{8}{|c|}{$2^{\circ}$ Corte } \\
\hline \multirow{5}{*}{$\begin{array}{l}\text { E } \\
\text { E } \\
\text { E }\end{array}$} & $T$ & 8,76 & 23,18 & 55,47 & 24,82 & 1,78 & 80,43 \\
\hline & V30 & 7,61 & 20,96 & 58,28 & 26,10 & 1,84 & 80,52 \\
\hline & V50 & 8,13 & 20,09 & 57,60 & 26,09 & 1,83 & 79,88 \\
\hline & V70 & 7,57 & 19,82 & 56,93 & 25,80 & 1,85 & 79,69 \\
\hline & V90 & 7,63 & 20,38 & 57,14 & 26,15 & 1,84 & 80,07 \\
\hline \multirow{6}{*}{ 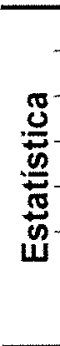 } & Média & 7,94 & 20,89 & 57,08 & 25,79 & 1,83 & 80,12 \\
\hline & C.V. & 4,26 & 4,59 & 2,08 & 2,52 & 2,45 & 0,98 \\
\hline & Teste F & $\star *$ & * & ns & ns & ns & ns \\
\hline & Reg.L. / $\mathbf{R}^{2}$ & $* * / 37,00$ & $\star * / 43,96$ & - & - & - & - \\
\hline & Reg.Q. $/ R^{2}$ & ns & ${ }^{*} / 69,97$ & - & - & - & - \\
\hline & Equação" & $\begin{array}{l}8,57325- \\
0,01155 v\end{array}$ & $\begin{array}{l}25,18222- \\
0,15434 v^{+} \\
0,00110 v^{2}\end{array}$ & - & - & - & - \\
\hline \multicolumn{8}{|c|}{$3^{\circ}$ Corte } \\
\hline \multirow{5}{*}{ 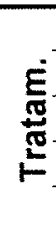 } & $T$ & 8,63 & 23,61 & 57,05 & 25,20 & 1,73 & 81,37 \\
\hline & V30 & 8,36 & 23,88 & 56,53 & 25,25 & 1,68 & 81,93 \\
\hline & V50 & 8,73 & 24,00 & 55,91 & 25,07 & 1,72 & 81,39 \\
\hline & V70 & 8,25 & 23,31 & 56,92 & 25,63 & 1,75 & 81,07 \\
\hline & V90 & 8,32 & 22,68 & 56,98 & 25,69 & 1,82 & 80,17 \\
\hline \multirow{6}{*}{ 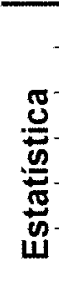 } & Média & 8,46 & 23,50 & 56,68 & 25,37 & 1,74 & 81,19 \\
\hline & C.V. & 5,69 & 3,45 & 2,26 & 3,55 & 3,23 & 1,56 \\
\hline & Teste F & ns & ns & $\mathrm{ns}$ & ns & $\mathrm{ns}$ & ns \\
\hline & Reg.L. $/ \mathbf{R}^{2}$ & - & - & - & - & - & - \\
\hline & Reg.Q. $/ \mathbf{R}^{2}$ & - & - & - & - & - & - \\
\hline & Equação\# & - & - & - & - & - & - \\
\hline
\end{tabular}

MM, PB, FDN, FDA e Lignina estão expressos em base de matéria seca e DIVMO em base de matéria orgânica. 
Tabela 70 - Análises bromatológicas $B$. humidicola cultivada no solo 01

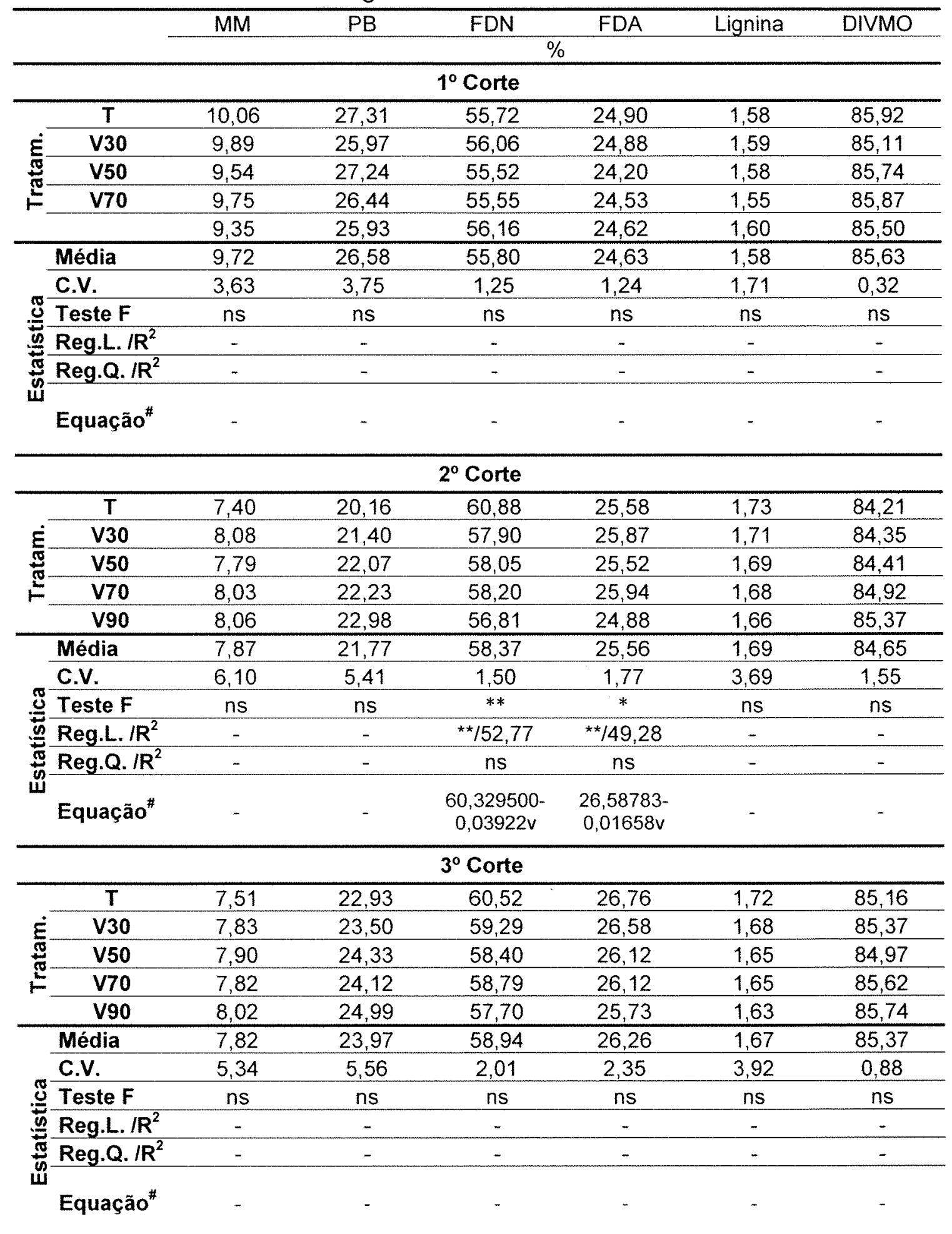

MM, PB, FDN, FDA e Lignina estão expressos em base de matéria seca e DIVMO em base de matéria orgânica. 
Tabela 71 - Análises bromatológicas $B$. humidicola cultivada no solo 02

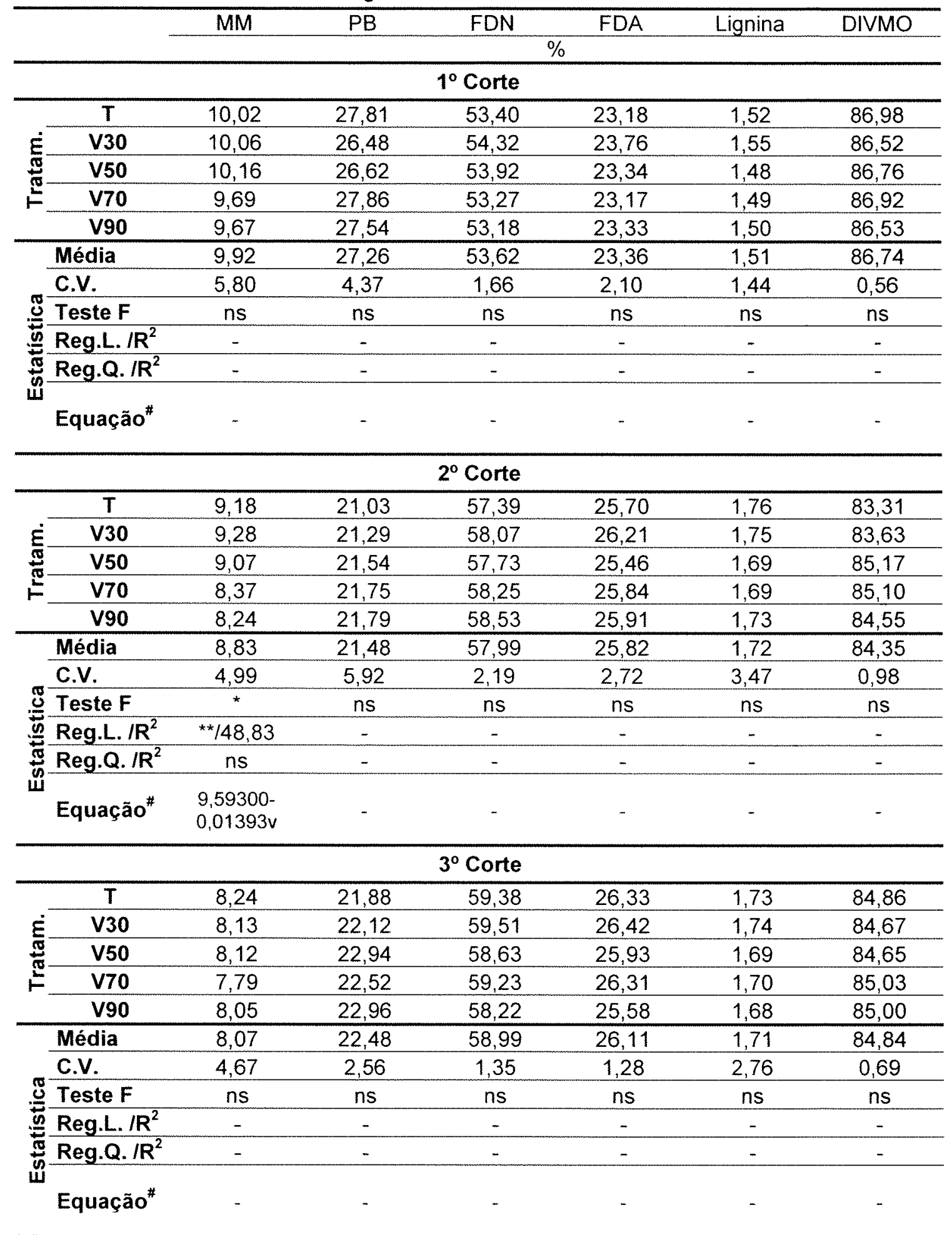

$M M, P B, F D N, F D A$ e Lignina estão expressos em base de matéria seca e DIVMO em base de matéria orgânica. 


\section{CDNCLUSÉES}

A avaliação dos resultados deste trabalho permitem as seguintes conclusões:

Existem diferenças entre as espécies quanto à necessidade de calcário, podendo-se classificar deste modo as espécies avaliadas na seguinte ordem decrescente em relação à necessidade de calagem: B.mutica $>$ E. pyramidalis $>E$. polystachya $>$ B. humidicola.

$\mathrm{O}$ benefício da calagem esta estreitamente relacionado ao fornecimento de cálcio e em menor grau ao de magnésio, já que em todas as ocasiões em que a calagem interferiu significativamente a produção, $90 \%$ desta foi alcançada na primeira dose de calcário utilizada (V30 para o solo1 e V35 para o solo 2), situação esta em que os solos ainda apresentavam elevada acidez e altos teores de Al trocável.

A composição das folhas, na maioria das oportunidades apresentam aumentos nos teores de $\mathrm{Ca}$ e $\mathrm{Mg}$, relação $\mathrm{Ca} / \mathrm{Mg}$ e B; reduções nos teores de $\mathrm{Na}$, Fe, Mn e Zn e efeitos não significativos para P, K, S, PB, FDN, FDA, DIVMO e lignina em função das crescentes saturações por bases avaliadas. Contudo variações ocorrem nas diferentes espécies, bem como entre os solos avaliados.

A metodologia empregada para determinação da CTC do solo não se mostrou adequada para ambos os solos avaliados. 
ANEXD 
Tabela 1-Equações de regressão dos parâmetros das análises de solo

\begin{tabular}{|c|c|c|c|c|c|}
\hline \multicolumn{6}{|c|}{ Pós Incubação solo 1} \\
\hline $\mathrm{pH}$ & $3,2279+0,0561 v-0,0003 v^{2}$ & $\mathrm{Ca}$ & $-1,5042+0,2426 v+0,0003 v^{2}$ & $\mathbf{R}$ & $0,2336+0,01716 v-0,0001 v^{2}$ \\
\hline MO & $28,2600-0,0340 \mathrm{v}$ & $\mathbf{M g}$ & $-0,0413+0,2826 \mathrm{v}$ & Vv & $-5,6125+1,5818 v-0,0075 v^{2}$ \\
\hline $\mathbf{P}$ & $9,5694-0,03183 v+0,00072 v^{2}$ & $\mathrm{Al}$ & $11,9461-0,3266 v+0,0022 v^{2}$ & Vf & $0,3881+0,9592 v$ \\
\hline $\mathbf{S}$ & $10,5625+0,0338 \mathrm{v}$ & CTC & $67,7535-0,7975 v+0,0088 v^{2}$ & $\mathbf{m}$ & $80,8058-2,4309 v+0,0174 v^{2}$ \\
\hline \multicolumn{6}{|c|}{ Pós Incubação solo 2} \\
\hline $\mathrm{pH}$ & $3,2063+0,05397 v-0,0002 v^{2}$ & $\mathrm{Ca}$ & $-9,0925+0,7235 v$ & $\mathbf{R}$ & $-0,0659+0,0162 v-0,0001 \mathrm{v}^{2}$ \\
\hline MO & $38,0300-0,046 \mathrm{v}$ & $\mathrm{Mg}$ & $-0,1388+1,1599 v-0,0027 v^{2}$ & Vv & $-22,5882+2,3118 v-0,01232 v^{2}$ \\
\hline $\mathbf{P}$ & $1,099+0,0190 v$ & Al & $32,7236-0,9072 v+0,0060 v^{2}$ & Vf & $-4,0435+1,1963 v-0,0017 v^{2}$ \\
\hline $\mathrm{K}$ & $2,9626-0,0187 v$ & CTC & $241,0940-3,9064 v+0,0338 v^{2}$ & $\mathbf{m}$ & $75,4664-2,1890 v+0,0149 v^{2}$ \\
\hline \multicolumn{6}{|c|}{ E. polystachya após $1^{\circ}$ Corte solo 1} \\
\hline $\mathrm{pH}$ & $3,4718+0,0271 \mathrm{v}$ & Al & $13,2056-0,2438 v+0,0011 v^{2}$ & $\mathrm{Cu}$ & $3,4483-0,0088 \mathrm{v}$ \\
\hline MO & $28,6567+0,020 v$ & $\mathbf{R}$ & $0,1840+0,0252 v-0,0002 v^{2}$ & $\mathrm{Fe}$ & $103,9572+0,1322 v-0,0029 v^{2}$ \\
\hline $\mathrm{Ca}$ & $-2,1000+0,2480 \mathrm{v}$ & $\mathbf{V}$ & $-0,3120+0,7501 \mathrm{v}$ & $\mathrm{Mn}$ & $16,2117-0,1178 \mathrm{v}$ \\
\hline $\mathrm{Mg}$ & $-0,6938+0,2394 v-0,0005 v^{2}$ & $\mathbf{m}$ & $88,9503-2,0703 v+0,0119 v^{2}$ & $\mathrm{Zn}$ & $6,7729-0,0556 v+0,0003 v^{2}$ \\
\hline \multicolumn{6}{|c|}{ E. polystachya após $1^{\circ}$ Corte solo 2} \\
\hline $\mathrm{pH}$ & $3,7329+0,0252 v$ & Al & $29,3701-0,7278 v+0,0044 v^{2}$ & $\mathrm{Fe}$ & $88,8936+0,2293 v-0,0064 v^{2}$ \\
\hline $\mathbf{P}$ & $60,0250+0,2650 v$ & $\mathbf{R}$ & $-0,0798+0,0182 v-0,0001 v^{2}$ & Mn & $62,6575-0,2905 \mathrm{v}$ \\
\hline $\mathrm{Ca}$ & $-7,5267+0,6213 v$ & $\mathbf{V}$ & $-0,4081+0,8493 v$ & $\mathrm{Zn}$ & $5,3858-0,0155 v$ \\
\hline $\mathrm{Mg}$ & $4,7317+0,7090 v$ & $\mathbf{m}$ & $76,3537-2,0811 v+0,0136 v^{2}$ & & \\
\hline \multicolumn{6}{|c|}{ E. pyramidalis após $1^{\circ}$ Corte solo 1} \\
\hline $\mathrm{pH}$ & $3,251+0,0250 v$ & $\mathbf{R}$ & $0,2333+0,0206 v-0,0001 v^{2}$ & $\mathrm{Fe}$ & $102,2623+0,7874 v-0,0099 v^{2}$ \\
\hline $\mathrm{Ca}$ & $-0,4558+0,1130 v+0,0015 v^{2}$ & $\mathbf{V}$ & $2,9088+0,4684 v+0,0034 v^{2}$ & Mn & $17,023-0,1343 \mathrm{v}$ \\
\hline $\mathrm{Mg}$ & $-0,5483+0,2062 v$ & $\mathbf{m}$ & $85,2220-1,8729 v+0,0103 v^{2}$ & $\mathrm{Zn}$ & $7,9133-0,0407 v$ \\
\hline $\mathrm{Al}$ & $10,9967-0,1270 \mathrm{v}$ & $\mathrm{B}$ & $0,7835+0,0049 v$ & & \\
\hline \multicolumn{6}{|c|}{ E. pyramidalis após $1^{\circ}$ Corte solo 2} \\
\hline $\mathrm{pH}$ & $3,4323+0,0424 v-0,0002 v^{2}$ & $\mathrm{Al}$ & $37,7831-1,0675 v+0,0072 v^{2}$ & $\mathrm{Fe}$ & $103,0000-0,3680 v$ \\
\hline Mo & $41,0908+0,0668 v-0,0009 v^{2}$ & $\mathbf{R}$ & $-0,0910+0,0188 v-0,0001 v^{2}$ & $\mathbf{M n}$ & $69,3833-0,4033 v$ \\
\hline $\mathbf{P}$ & $67,3333+0,1333 v$ & $\mathbf{V}$ & $0,3133+0,8320 \mathrm{v}$ & $\mathrm{Zn}$ & $4,4842+0,0333 v-0,0004 v^{2}$ \\
\hline $\mathrm{Ca}$ & $-6,9800+0,5987 v$ & $\mathbf{m}$ & $84,5338-2,4546 v+0,0168 v^{2}$ & & \\
\hline $\mathrm{Mg}$ & $4,8233+0,6993 \mathrm{v}$ & $\mathbf{B}$ & $0,9461+0,0340 v-0,0003 \mathrm{v}^{2}$ & & \\
\hline \multicolumn{6}{|c|}{ B.mutica após $1^{\circ}$ Corte solo 1} \\
\hline $\mathrm{pH}$ & $3,4523+0,0248 v$ & Al & $11,9604-0,1926 v+0,0006 v^{2}$ & $\mathrm{Cu}$ & $5,1358-0,0560 v+0,0004 v^{2}$ \\
\hline Mo & $29,4933+0,0427 v$ & $\mathbf{R}$ & $0,3086+0,0202 v-0,0001 v^{2}$ & Mn & $18,5217-0,1235 v$ \\
\hline $\mathbf{P}$ & $112,6559-1,2414 v+0,0086 v^{2}$ & $\mathbf{V}$ & $1,6418+0,6182 v+0,0011 v^{2}$ & $\mathrm{Zn}$ & $9,4989-0,1171 v+0,0007 v^{2}$ \\
\hline $\mathrm{Ca}$ & $-0,6895+0,1616 v+0,0009 v^{2}$ & $\mathbf{m}$ & $87,8719-2,0412 v+0,0118 v^{2}$ & & \\
\hline $\mathrm{Mg}$ & $0,2917+0,1768 \mathrm{v}$ & B & $0,8617+0,0048 \mathrm{v}$ & & \\
\hline \multicolumn{6}{|c|}{ B.mutica após $1^{\circ}$ Corte solo 2} \\
\hline pH & $3,7664+0,0268 v$ & Al & $25,2111-0,7063 v+0,0047 v^{2}$ & $\mathrm{~B}$ & $1,5898+0,0172 v-0,0002 v^{2}$ \\
\hline $\mathrm{K}$ & $4,1709-0,0548 v+0,0003 v^{2}$ & $\mathbf{R}$ & $-0,0974+0,0213 v-0,0001 v^{2}$ & $\mathrm{Fe}$ & $109,1594+0,5572 v-0,0104 v^{2}$ \\
\hline $\mathrm{Ca}$ & $-6,8542+0,6178 v$ & $\mathbf{V}$ & $-0,2043+0,8331 \mathrm{v}$ & Mn & $64,3233-0,4313 v$ \\
\hline $\mathbf{M g}$ & $3,1192+0,7085 v$ & $\mathbf{m}$ & $69,1691-2,0095 v+0,0137 v^{2}$ & $\mathbf{Z n}$ & $4,8923+0,0634 v-0,0009 v^{2}$ \\
\hline
\end{tabular}

$\frac{\mathrm{Rg}}{\mathrm{R} \text {-relaçāo } \mathrm{Ca} / \mathrm{Mg}}$ 
Tabela 2- Equações de regressão dos parâmetros das análises de solo (continuação).

\begin{tabular}{|c|c|c|c|c|c|}
\hline \multicolumn{6}{|c|}{ B.humidicola após $1^{\circ}$ Corte solo 1} \\
\hline pH & $3,2918+0,0219 \mathrm{v}$ & Mg & $-0,1271+0,1831 v+0,0006 v^{2}$ & B & $0,8017+0,0092 v$ \\
\hline MO & $31,6733+0,035 \mathrm{v}$ & $\mathbf{A l}$ & $12,3886-0,1735 v+0,0004 v^{2}$ & $\mathrm{Cu}$ & $3,1800-0,0093 \mathrm{v}$ \\
\hline $\mathbf{P}$ & $64,9976-0,3847 v+0,0048 v^{2}$ & $\mathbf{R}$ & $0,3040+0,0196 v-0,0001 v^{2}$ & $\mathrm{Fe}$ & $144,4652-1,1129 v+0,0063 v^{2}$ \\
\hline $\mathbf{K}$ & $1,7917+0,0088 \mathrm{v}$ & V & $1,6254+0,5623 v+0,0042 v^{2}$ & $M n$ & $14,3648-0,1471 v+0,0006 v^{2}$ \\
\hline $\mathrm{Ca}$ & $-0,7735+0,1381 v+0,0017 v^{2}$ & $\mathbf{m}$ & $86,7856-1,9425 v+0,011 v^{2}$ & $\mathrm{Zn}$ & $7,4233-0,0350 \mathrm{v}$ \\
\hline \multicolumn{6}{|c|}{ B.humidicola após $1^{\circ}$ Corte solo 2} \\
\hline $\mathrm{pH}$ & $3,6504+0,0263 v$ & Al & $36,2192-0,9688 v+0,0063 v^{2}$ & $\mathrm{Cu}$ & $2,6842-0,0038 \mathrm{v}$ \\
\hline MO & $40,7908+0,0428 \mathrm{v}$ & $\mathbf{R}$ & $-0,1016+0,0217 v-0,0001 v^{2}$ & $\mathrm{Fe}$ & $103,2933-0,3973 v$ \\
\hline $\mathbf{K}$ & $4,2604-0,0501 v+0,0004 v^{2}$ & $\mathbf{V}$ & $-0,4908+0,8585 v$ & Mn & $59,2217-0,4077 v$ \\
\hline $\mathrm{Ca}$ & $-7,1542+0,6352 \mathrm{v}$ & $\mathrm{m}$ & $82,9899-2,3269 v+0,0156 v^{2}$ & $\mathrm{Zn}$ & $6,7624-0,0592 v+0,0003 v^{2}$ \\
\hline $\mathrm{Mg}$ & $2,9342+0,7142 v$ & B & $2,0670+0,0044 v$ & & \\
\hline \multicolumn{6}{|c|}{ E. polystachya após $2^{\circ}$ Corte solo 1} \\
\hline$\overline{\mathrm{pH}}$ & $3,5050-0,0038 v+0,0002 v^{2}$ & Al & $15,5250-0,1558 \mathrm{v}$ & $\mathbf{B}$ & $0,4639-0,0013 v+0,0001 v^{2}$ \\
\hline $\mathbf{P}$ & $49,8357-0,4886 v+0,0035 v^{2}$ & $\mathbf{R}$ & $0,1961+0,05383 v-0,0005 v^{2}$ & $\mathrm{Cu}$ & $3,4550-0,0155 \mathrm{v}$ \\
\hline $\mathrm{Ca}$ & $-0,4692+0,1263 v+0,0008 v^{2}$ & V & $4,6155+0,1905 v+0,0039 v^{2}$ & Mn & $4,6407+0,2181 \mathrm{v}-0,0025 \mathrm{v}^{2}$ \\
\hline Mg & $1,3673-0,0095 v+0,0015 v^{2}$ & $\mathbf{m}$ & $91,7709-1,3084 v+0,0037 v^{2}$ & & \\
\hline \multicolumn{6}{|c|}{ E. polystachya após $2^{\circ}$ Corte solo 2} \\
\hline $\mathrm{pH}$ & $3,6434+0,025 \mathrm{v}$ & $\mathrm{Al}$ & $62,4149-1,6131 v+0,010 v^{2}$ & $\mathrm{Cu}$ & $1,8808+0,0035 \mathrm{v}$ \\
\hline $\mathbf{P}$ & $38,0899-0,4498 v+0,0051 v^{2}$ & $\mathbf{R}$ & $-0,1902+0,0242 v-0,0002 v^{2}$ & $\mathrm{Fe}$ & $133,3167-0,4300 \mathrm{v}$ \\
\hline $\mathbf{C a}$ & $-7,0592+0,5408 \mathrm{v}$ & $\mathbf{V}$ & $-1,9174+0,7087 \mathrm{v}$ & Mn & $48,1383-0,2163 \mathrm{v}$ \\
\hline $\mathrm{Mg}$ & $2,3725+0,5685 v$ & $\mathbf{m}$ & $113,7886-2,9445 v+0,0185 v^{2}$ & Zn & $6,4132-0,063 v+0,0005 v^{2}$ \\
\hline \multicolumn{6}{|c|}{ E. pyramidalis após $2^{\circ}$ Corte solo 1} \\
\hline pH & $3,4969-0,0058 v+0,0002 v^{2}$ & Al & $20,9298+0,0328 v-0,0027 v^{2}$ & $\mathrm{Cu}$ & $2,6988+0,033 v-0,0004 v^{2}$ \\
\hline $\mathbf{P}$ & $67,4071-0,5624 v+0,0037 v^{2}$ & $\mathbf{R}$ & $0,3189+0,0566 v-0,0005 v^{2}$ & $\mathrm{Fe}$ & $134,3840+0,5214 v-0,0066 v^{2}$ \\
\hline $\mathrm{K}$ & $1,5183-0,0032 v$ & V & $6,7889-0,055 v+0,0068 v^{2}$ & Mn & $3,8989+0,1765 \mathrm{v}-0,0018 \mathrm{v}^{2}$ \\
\hline $\mathrm{Ca}$ & $0,7958+0,0250 v+0,0019 v^{2}$ & $\mathbf{m}$ & $90,5798-0,4351 v-0,0055 v^{2}$ & $\mathrm{Zn}$ & $3,2440+0,0491 \mathrm{v}-0,0005 \mathrm{v}^{2}$ \\
\hline Mg & $1,6912-0,0569 v+0,0021 v^{2}$ & B & $0,4158-0,0037 v+0,00003 v^{2}$ & & \\
\hline \multicolumn{6}{|c|}{ E. pyramidalis após $2^{\circ}$ Corte solo 2} \\
\hline $\mathrm{pH}$ & $3,4796+0,0235 \mathrm{v}$ & $\mathrm{Ca}$ & $-5,4275+0,4698 \mathrm{v}$ & $\mathbf{V}$ & $-0,5833+0,6600 \mathrm{v}$ \\
\hline MO & $41,6000-0,0200 \mathrm{v}$ & Mg & $2,6900+0,5647 v$ & $\mathbf{m}$ & $112,9234-2,5351 v+0,0142 v^{2}$ \\
\hline $\mathbf{P}$ & $46,5000-0,5867 v+0,0067 v^{2}$ & Al & $71,0122-1,5677 v+0,0086 v^{2}$ & $\mathrm{Fe}$ & $96,3515+0,3897 v-0,0060 v^{2}$ \\
\hline $\mathbf{K}$ & $1,8375-0,0052 v$ & $\mathbf{R}$ & $-0,1393+0,0215 v-0,0001 v^{2}$ & Mn & $29,3832+0,1929 v-0,0029 v^{2}$ \\
\hline \multicolumn{6}{|c|}{ B.mutica após $2^{\circ}$ Corte solo 1} \\
\hline $\mathrm{pH}$ & $3,5928-0,0062 v+0,0002 v^{2}$ & $\overline{A l}$ & $24,2667-0,2267 \mathrm{v}$ & $\mathrm{Fe}$ & $181,2361+0,9237 v-0,012 v^{2}$ \\
\hline $\mathbf{P}$ & $60,3011-0,6609 v+0,0042 v^{2}$ & $\mathbf{R}$ & $0,3824+0,0486 v-0,0004 v^{2}$ & Mn & $5,2248+0,1925 v-0,0023 v^{2}$ \\
\hline $\mathrm{K}$ & $1,1667-0,0047 v$ & V & $5,5224+0,0857 v+0,0047 v^{2}$ & $\mathrm{Zn}$ & $4,3783+0,0180 v-0,0003 v^{2}$ \\
\hline $\mathrm{Ca}$ & $0,5907+0,0654 v+0,0013 v^{2}$ & $\mathbf{m}$ & $98,1217-0,9881 \mathrm{~V}$ & & \\
\hline $\mathrm{Mg}$ & $1,3359-0,0054 v+0,0013 v^{2}$ & $\mathrm{Cu}$ & $3,7300-0,0170 \mathrm{v}$ & & \\
\hline \multicolumn{6}{|c|}{ B.mutica após $2^{\circ}$ Corte solo 2} \\
\hline pH & $3,5952+0,027 \mathrm{v}$ & $\mathrm{Mg}$ & $2,3108+0,5828 \mathrm{v}$ & B & $1,8103-0,0047 v$ \\
\hline MO & $38,2336+0,1342 v-0,0009 v^{2}$ & Al & $52,8800-1,2668 v+0,0074 v^{2}$ & $\mathrm{Fe}$ & $144,0350-0,7623 v$ \\
\hline $\mathbf{P}$ & $35,1500+0,1900 v$ & $\mathbf{R}$ & $-0,1507+0,0234 v-0,0001 v^{2}$ & $\mathrm{Mn}$ & $57,4139-0,5804 v+0,0023 v^{2}$ \\
\hline $\mathbf{K}$ & $1,3225-0,0042 v$ & $\mathbf{V}$ & $-1,6048+0,7078 v$ & & \\
\hline $\mathbf{C a}$ & $-6,1850+0,5257 v$ & $\mathbf{m}$ & $107,6322-2,6851 v+0,016 v^{2}$ & & \\
\hline
\end{tabular}

R- relação $\mathrm{Ca} / \mathrm{Mg}$ 
Tabela 3- Equações de regressão dos parâmetros das análises de solo (continuação).

\begin{tabular}{|c|c|c|c|c|c|}
\hline \multicolumn{6}{|c|}{ B.humidicola após $2^{\circ}$ Corte solo 1} \\
\hline pH & $3,5915-0,0094 v+0,0003 v^{2}$ & $\mathrm{Al}$ & $27,1500-0,2950 \mathrm{v}$ & $\mathrm{Cu}$ & $3,5800-0,0160 \mathrm{v}$ \\
\hline $\mathbf{P}$ & $49,9071-0,4923 v+0,0037$ & $\mathbf{R}$ & $0,2839+0,0478 v-0,0004 v^{2}$ & $\mathrm{Fe}$ & $170,9869+2,1345 \mathrm{v}-0,0298 \mathrm{v}^{2}$ \\
\hline $\mathbf{C a}$ & $-0,2742+0,1120 v+0,0012 v^{2}$ & $\mathbf{V}$ & $3,8923+0,1799 v+0,0049 v^{2}$ & Mn & $10,1850-0,0133 v-0,0006 v^{2}$ \\
\hline $\mathrm{Mg}$ & $1,2893-0,0048 v+0,0016 v^{2}$ & $\mathbf{m}$ & $99,5517-1,0892 \mathrm{v}$ & $\mathrm{Zn}$ & $4,3512+0,0307 v-0,0004 v^{2}$ \\
\hline \multicolumn{6}{|c|}{ B.humidicola após $2^{\circ}$ Corte solo 2} \\
\hline $\mathrm{pH}$ & $3,5675+0,02217 v$ & $\mathrm{Mg}$ & $2,8850+0,5783 v$ & $\bar{m}$ & $116,4053-2,8869 v+0,0176 v^{2}$ \\
\hline $\mathbf{P}$ & $51,1667+0,3133 v$ & Al & $70,8485-1,7504 v+0,0107 v^{2}$ & $\mathrm{Fe}$ & $109,4383-0,3483 v$ \\
\hline $\mathrm{K}$ & $17700-0,0087 v$ & $\mathbf{R}$ & $-0,1166+0,02202 v-0,0001 v^{2}$ & Mn & $39,9332+0,0244 v-0,0023 v^{2}$ \\
\hline $\mathbf{C a}$ & $-6,5025+0,5522 v$ & $\mathbf{V}$ & $-1,2008+0,7193 v$ & $\mathbf{Z n}$ & $3,2377+0,0926 v-0,0008 v^{2}$ \\
\hline \multicolumn{6}{|c|}{ E. polystachya após $3^{\circ}$ Corte solo 1} \\
\hline MO & $26,1250+0,0842 v$ & $\overline{A l}$ & $39,5833-0,2450 \mathrm{v}$ & $\mathrm{Cu}$ & $4,0933-0,0160 \mathrm{v}$ \\
\hline $\mathbf{P}$ & $52,5000-0,2367 \mathrm{v}$ & $\mathbf{R}$ & $-0,0825+0,0898 v-0,0008 v^{2}$ & Mn & $2,3096+0,0083 v+0,0004 v^{2}$ \\
\hline $\mathbf{K}$ & $2,2233-0,0050 \mathrm{v}$ & V & $4,8999+0,1583 v+0,0010 v^{2}$ & $\mathrm{Zn}$ & $1,6930+0,0453 v-0,0003 v^{2}$ \\
\hline $\mathbf{C a}$ & $-0,4350+0,1068 v$ & $\mathbf{m}$ & $99,4700-0,5430 v$ & & \\
\hline $\mathbf{M g}$ & $1,1044-0,0139 v+0,0006 v^{2}$ & B & $0,3946-0,0053 v+0,00004 v^{2}$ & & \\
\hline \multicolumn{6}{|c|}{ E. polystachya após $3^{\circ}$ Corte solo 2} \\
\hline$\overline{\mathrm{pH}}$ & $3,5170+0,0186 v$ & Al & $98,0583-1,0750 \mathrm{v}$ & $\mathrm{Cu}$ & $1,5817+0,0110 v$ \\
\hline $\mathrm{K}$ & $2,0633-0,0073 v$ & $\mathbf{R}$ & $0,1167+0,0091 \mathrm{v}$ & $\mathrm{Fe}$ & $89,7817-0,1730 \mathrm{v}$ \\
\hline $\mathrm{Ca}$ & $-2,6161+0,2375 v+0,0020 v^{2}$ & $\mathbf{V}$ & $-2,1636+0,5612 v$ & Mn & $39,7900-0,0980 \mathrm{~V}$ \\
\hline Mg & $1,6875+0,4235 v$ & $\mathbf{m}$ & $106,8541-1,1525 \mathrm{v}$ & $\mathrm{Zn}$ & $3,9799+0,0096 v-0,0002 v^{2}$ \\
\hline \multicolumn{6}{|c|}{ E. pyramidalis após $3^{\circ}$ Corte solo 1} \\
\hline $\mathbf{P}$ & $66,7202+0,0138 v-0,0032 v^{2}$ & $\mathbf{R}$ & $1,2887+0,0112 \mathrm{v}$ & $\mathrm{Mn}$ & $0,7627+0,1425 v-0,0008 v^{2}$ \\
\hline $\mathrm{Ca}$ & $0,7138+0,0239 v+0,0009 v^{2}$ & $\mathbf{V}$ & $4,3152+0,0639 v+0,0020 v^{2}$ & $\mathrm{Zn}$ & $1,5467+0,0300 \mathrm{v}$ \\
\hline Mg & $0,6429+0,0147 v+0,0003 v^{2}$ & $\mathbf{m}$ & $99,8300-0,3783 v$ & & \\
\hline Al & $47,0000-0,2133 \mathrm{v}$ & B & $0,4565-0,0017 v$ & & \\
\hline \multicolumn{6}{|c|}{ E. pyramidalis após $3^{\circ}$ Corte solo 2} \\
\hline $\mathrm{pH}$ & $3,4756+0,0169 v$ & Al & $179,4169-4,7106 v+0,031 v^{2}$ & $\mathrm{Cu}$ & $0,8018+0,0493 v-0,0003 v^{2}$ \\
\hline K & $2,1525-0,0088 \mathrm{v}$ & $\mathbf{R}$ & $-0,0253+0,0164 v-0,00007 v^{2}$ & $\mathrm{Fe}$ & $92,5567-0,1500 \mathrm{v}$ \\
\hline $\mathrm{Ca}$ & $-2,6948+0,2299 v+0,0020 v^{2}$ & $\mathbf{V}$ & $-3,3122+0,5752 v$ & Mn & $23,3971+0,3278 v-0,0026 v^{2}$ \\
\hline $\mathbf{M g}$ & $-0,0617+0,4517 v$ & $\mathbf{m}$ & $132,3010-2,7101 v+0,0142 v^{2}$ & & \\
\hline \multicolumn{6}{|c|}{ B.mutica após $3^{\circ}$ Corte solo 1} \\
\hline $\mathrm{pH}$ & $3,7499-0,0080 v+0,0001 v^{2}$ & $\mathrm{Mg}$ & $1,1318-0,0208 v+0,0007 v^{2}$ & $\mathbf{m}$ & $87,089+0,2531 v-0,0058 v^{2}$ \\
\hline $\mathbf{P}$ & $55,4500-0,1583 \mathrm{v}$ & $\overrightarrow{A l}$ & $29,1286+0,5771 v-0,0069 v^{2}$ & B & $0,4437-0,0031 v+0,00002 v^{2}$ \\
\hline K & $2,0567-0,0130 \mathrm{v}$ & $\mathbf{R}$ & $0,3203+0,0776 v-0,0007 v^{2}$ & Mn & $4,2288+0,02003 v+0,0003 v^{2}$ \\
\hline $\mathrm{Ca}$ & $0,7732+0,0268 v+0,0007 v^{2}$ & $\mathbf{V}$ & $7,1002-0,0256 v+0,0026 \mathrm{v}^{2}$ & $\mathrm{Zn}$ & $3,4468-0,0181 v+0,0003 v^{2}$ \\
\hline \multicolumn{6}{|c|}{ B.mutica após $3^{\circ}$ Corte solo 2} \\
\hline $\mathrm{pH}$ & $3,3156+0,0245 v$ & $\mathrm{Mg}$ & $0,0825+0,4772 v$ & B & $1,0690+0,0068 v-0,0001 v^{2}$ \\
\hline MO & $46,5105-0,0930 v+0,0015 v^{2}$ & Al & $185,8702-4,4538 v+0,026 v^{2}$ & $\mathrm{Cu}$ & $0,4919+0,0766 v-0,0006 v^{2}$ \\
\hline $\mathbf{P}$ & $28,3250+0,085 v$ & $\mathbf{R}$ & $-0,0246+0,0189 v-0,0001 v^{2}$ & $\mathrm{Fe}$ & $93,9762+0,5335 v-0,0081 v^{2}$ \\
\hline $\mathbf{K}$ & $1,6191-0,0196 v+0,0001 v^{2}$ & $\mathbf{V}$ & $-3,4377+0,6102 \mathrm{v}$ & $M n$ & $19,7670+0,7026-0,0067 \mathrm{v}^{2}$ \\
\hline $\mathrm{Ca}$ & $-6,8583+0,4830 \mathrm{v}$ & $m$ & $132,9203-2,5193 v+0,012 v^{2}$ & $\mathrm{Zn}$ & $2,3162+0,0276 v-0,0002 v^{2}$ \\
\hline
\end{tabular}

R- relação Ca/Mg 
Tabela 4- Equações de regressão dos parâmetros das análises de solo (continuação).

B.humidicola após $3^{\circ}$ Corte solo 1

\begin{tabular}{|c|c|c|c|c|c|}
\hline pH & $3,4933-0,0029 v+0,0001 v^{2}$ & $\mathbf{R}$ & $0,3929+0,0774 v-0,0007 v^{2}$ & $\mathrm{Fe}$ & $136,4648+0,4502 v-0,0058 v^{2}$ \\
\hline $\mathrm{Ca}$ & $04362+0,0190 v+0,0015 v^{2}$ & V & $4,4042-0,0299 v+0,0044 v^{2}$ & Mn & $1,4575+0,1400 v-0,0007 v^{2}$ \\
\hline $\mathrm{Mg}$ & $1,033-0,0319 v+0,0011 v^{2}$ & $\mathbf{m}$ & $91,6535+0,3456 v-0,0112 v^{2}$ & $\mathrm{Zn}$ & $1,6546+0,0873 v-0,0007 v^{2}$ \\
\hline $\mathrm{Al}$ & $43,6012+0,1357 v-0,0058 v^{2}$ & $\mathrm{Cu}$ & $3,6617-0,0088 \mathrm{v}$ & & \\
\hline \multicolumn{6}{|c|}{ B.humidicola após $3^{\circ}$ Corte solo 2} \\
\hline $\mathrm{pH}$ & $3,5576+0,020 \mathrm{v}$ & $\mathrm{Al}$ & $131,8482-2,9731 v+0,0168 v^{2}$ & $\mathrm{Cu}$ & $1,2409+0,0579 v-0,0004 v^{2}$ \\
\hline $\mathbf{P}$ & $28,6815+0,4002 v-0,0032 v^{2}$ & $\mathbf{R}$ & $0,0019+0,0201 v-0,0001 v^{2}$ & $\mathrm{Fe}$ & $105,7433-0,2887 v$ \\
\hline $\mathrm{Ca}$ & $-4,0015+0,3306 v+0,0017 v^{2}$ & $\mathbf{V}$ & $-4,8324+0,6328 v$ & Mn & $41,4806+0,1613 v-0,0035 v^{2}$ \\
\hline $\mathrm{Mg}$ & $-1,3950+0,4767 v$ & $\mathbf{m}$ & $129,2090-2,4495 v+0,0112 v^{2}$ & $\mathrm{Zn}$ & $3,8765+0,0387 v-0,0004 v^{2}$ \\
\hline
\end{tabular}

$\mathrm{R}$ - relação Ca/Mg 


\section{REFERÊNCIAS BIBLIOGRÁFICAS}

ABRUÑA, F; FIGARELLA , J. Some effects of calcium and phosphorus fertilization on the yield and composition of a tropical kudzu-grass pasture. Journal of Agriculture of the University of Puerto Rico, v. 41, n.4, p.231-235, 1957.

ABRUÑA, F.; PEARSON, R. W; ELKINS, C. B. Quantitative evaluation of soil reaction and base status changes resulting from field application of residually acidforming nitrogen fertilizers. Soil Science Society of America Proceedings, v.22, n. 6, p.539-542, 1958.

ABRUÑA, F.; VICENTE-CHANDLER, J.; PEARSON, R. W. Effects of liming on yields and composition of heavily fertilized grasses and on soil properties under humid tropical conditions. Soil Science Society of America Proceedings, v.28, p.661-675, 1964.

ASSOCIATION OF OFFICIAL ANALYTICAL CHEMISTS. Official methods of analysis of AOAC international. 16.ed. Washington, 1995. 2v.

BARROS, N. F. de. Potássio. In: UNIVERSIDADE FEDERAL DE VIÇOSA. SOL370: química e fertilidade do solo. Viçosa, 1990. p.158-175.

BATAGLIA, O. C.; RAIJ, B. van. Eficiência de extratores de micronutrientes na análise de solos. Revista Brasileira de Ciência do Solo, v.13, p.205 -212, 1989.

BATAGLIA, O. C.; FURLANI, A. M. C.; TEIXEIRA, J. P. F. et al. Métodos de análise química de plantas. Campinas: IAC, 1983. 48p. (IAC. Boletim Técnico, 78).

BERGMANN, W. Nutritional desorders of plants, development: visual and analytical diagnosis. Jena: Gustav Fisher, 1992. 741p. 
BLEVINS, D. G. Uptake, translocation, and function of essential mineral elements in crop plants. In: BOOTE, K. J.; BENNETT, J. M.; SINCLAIR, T. R.; PAULSEN, G. M. Physiology and determination of crop yield. Madison: American Society of Agronomy, 1994. p. 259-275.

BOGDAN, A. V. Tropical pastures and fodder plants. London: Longman, 1977. $475 \mathrm{p}$.

BOTREL, M. A. Fatores de adaptação de espécies forrageiras. Curso de Pecuária Leiteira. Coronel Pacheco: EMBRAPA-CNPGL, 1990. 21p.

BRASIL. Departamento Nacional de Produção Mineral. Projeto RADAM: levantamento de recursos Naturais. Rio de Janeiro, 1974. 16v.

BRENES, E.; PEARSON, R. W. Root responses of three gramineae species to soil acidity in an oxisol and an ultisol. Soil Science, v. 116 n.4, p. 295-302, 1973.

CAMARGO, M. N.; KLANT, E.; KAUFFMAN, J. H. Classificação de solos usados em levantamentos pedológicos no Brasil. Boletim Informativo da Sociedade Brasileira de Ciência do Solo, v.12, n.1, p. 11-33, 1987.

CARRIEL, J. M.; WERNER, J. C.; ABRAMIDES, P. L. G.; MONTEIRO, A. F.; MEIRELLES, N. M. F. Limitações nutricionais de um solo podzólico vermelhoamarelo para o cultivo de três gramíneas forrageiras. Boletim da Indústria Animal, v.46, n.1, p.61-73, 1989.

CATANI, R. A.; ALONSO. Extração do Al trocável e o pH do solo. Anais da Escola Superior de Agricultura "Luiz de Quiroz", v.26, p.21-29, 1969.

CENTRO INTERNACIONAL DE AGRICULTURA TROPICAL. Annual report. Cali, 1978. 405p.

CERRI, C. C.; VOLKOFF, B. Matéria Orgânica de Três Solos dos Campos Inundáveis da Illha de Marajó (PA). Revista Brasileira de Ciência do Solo. v.12, n.2, p.93-100, maio/ago. 1988.

CHEW, W. Y.; WILLIAMS, C. N.; ISMAIL, L.; RAMLI, K. Effects of liming and soil $\mathrm{pH}$ on guinea grass in Malaysian tropical oligotrophic peat. Experimental Agriculture, v.16, p.263-267, 1980. 
COLEMAN, N. T.; KAMPRATH, R. J.; WEED, S. D. Liming. Advances in Agronomy, v.10, p.475-522, 1958.

COLOZZA, M. T. Calcário e gesso em um latossolo vermelho-amarelo cultivado com uma pastagem cosorciada de soja-perene e colonião. Piracicaba, 1993. 218p. Dissertação (Mestrado) - Escola Superior de Agricultura "Luiz de Queiroz", Universidade de São Paulo.

CORREIA, A. A. D. Bioquímica nos solos, pastagens, e forrageiras. Lisboa: Fundação Calouste Gulbenian, 1981. 787p.

DEER, W.A.; HOWIE, R.A.; ZUSSMAN, J. An introduction to the rock-forming minerals. New York: John Wiley, 1969. 528p.

DEFELIPO, B. V. Reação do solo / correção da acidez do solo. In: UNIVERSIDADE FEDERAL DE VIÇOSA. SOL-370 : Química e fertilidade do solo. Viçosa, 1990. p.73-117.

De-POLLI, H; ALMEIDA, D. L.; FREIRE L. R. et al. Manual de adubação para o Rio de Janeiro. Itaguaí: Ed.UFRRJ, 1988. 179p.

EMPRESA BRASILEIRA DE PESQUISA AGROPECUÁRIA. Centro Nacional de Pesquisas de Solos. Sistema brasileiro de classificação de solos. Brasília, 1999. $412 \mathrm{p}$.

FOY, C.D. Physiological effects of hydrogen, aluminum, and manganese toxities in acid soil In: ADAMS, F.; DINAUER, R.C.; GATES, K.E.; BUXTON, D.R. Soil acidity and liming. Madison: American Society of Agronomy, 1984. p.57-97.

FOY, C.D. Plant adaptation to acid, aluminum-toxic soils. Communications in Soil Science and Plant Analysis, v.19, n.1, p.959-987, 1988.

FOY,C.D.; FLEMING, A.L. Aluminum tolerance of two wheat genotypes related to nitrate reductase activities. Journal of Plant Nutrition, v.5, p.1313-1333, 1982.

FOY, C.D.; BORNS, G.R.; BROW, J.C. Differential aluminum tolerance of two wheat varieties associated with plant induced $\mathrm{pH}$ changes ground their roots. Soil Science Society of America Proceedings, v.29, n.1, p.64-67, 1965. 
GOEDERT, W. J.; RITCHEEY, K. D.; SANZONOWICZ, C. Desenvolvimento radicular do capim Andropogon e sua relação com teor de $\mathrm{Ca}$ no perfil do solo. Revista Brasileira de Ciência do Solo, v. 9, n. 1, p. 89-91, 1985.

GÖHL, B. O. Tropical feeds: feeds information, summaries, and nutritive value. Rome: FAO, 1975. 123p.

GOMIDE, J. A.; ZAGO, C. P.; RIBEIRO, A. C.; BRAGA, J. M.; MARTINS, O. Calagem, fontes e níveis de fósforo no estabelecimento e produção do capim colonião no cerrado. Revista da Sociedade Brasileira de Zootecnia, v. 15, n. 3, p. 241-246, 1986.

GONÇALVES, C. A.; COSTA, N. L.; RODRIGUES, A. N. A. Efeito da calagem sobre o rendimento de forragem e composição química de Andropogon gayanus cv. Planaltina (compact disc). In: REUNIÃO ANUAL DA SOCIEDADE BRASILEIRA DE ZOOTECNIA, 37.,Viçosa, 2000. Anais. Viçosa: SBZ, 2000.

HOPKINS, W. G. Introdution to plant physiology. New York: John Wiley, 1995. $464 \mathrm{p}$.

HORST, W.J.; PÜSCHEL,A.K.; SCHMOHL,N. Induction of callose formation is a sensitive marker for genotypic aluminum sensitivyty in maize. Plant and Soil, v.192, p.23-30, 1997.

HUMPHREYS, L. R. Tropical pastures and fodder crops. 2.ed. London: Longman, 1987. 155p.

JORGE, J. A. Solo: manejo e adubação. São Paulo: Nobel, 1983. 83p.

KAMPRATH, E. J. Exchanggeable aluminium as a criterium for liming leached mineral soils. Soil Science Society of America Proceedings., v. 34, p.252-254, 1970.

KARP, G. Cell and molecular biology. New York:John Wiley, 1996. 773p.

KELTJENS, W. G.; TAN, K. Z. Interactions between aluminum, magnesium and calcium with different monocotyledonous and dicotyledonous plant-species Plant and Soil, v.156, p.485-488, 1993.

KINRAIDE, T. B. Identity of rhizotoxic aluminium species. Plant and Soil, v. 134, p.167-178, 1991. 
KINRAIDE, T. B.; RYAN, P. R.; KOCHIAN, L. V. Interactive effects of $\mathrm{Al}^{3+}, \mathrm{H}^{+}$, and other cations on root elongation considered in terms of cell-surface eletrical potential. Plant Physiology, v.99, p.1461-1468, 1992.

KOCHIAN, L. V. Cellular mechasnisms of aluminum toxicity and resistance in plants. Annual Review of Plant and Molecular Biology, v.46, p237-260, 1995.

LOPES, A.; GUIMARÃES, P. T. G. Recomendações para o uso de corretivos e fertilizantes em Minas Gerais - $4^{\text {a }}$ aproximação. Lavras:CFSEMG, 1989. 176p.

LOTERO, J.; MONSALVE, S. A. ; RAMIREZ, A.; VILLAMIZAR, F. Respuesto de gramineas y leguminosas forrajeras al ancalamiento. Suelos Equatorial, v.3, p.210$239,1971$.

LUZ, P. H. C.; BRAGA, G. J.;HERLING, V. R.; LIMA, C. G. Avaliação da composição química e digestibilidade "in vitro" do Panicum maximum Jacq. cv. Tobiatã submetido à doses, tipos e incorporação de calcário (compact disc). In: REUNIÃO ANUAL DA SOCIEDADE BRASILEIRA DE ZOOTECNIA, 36., Porto Alegre, 1999. Anais. Porto Alegre: SBZ, 1999.

MALAVOLTA, E. Elementos de nutrição mineral de plantas. São Paulo: Agronômica Ceres, 1980. 251p.

MALAVOLTA, E. Seminário sobre corretivos agrícolas. Campinas: Fundação Cargill, 1985. 352p.

MALAVOLTA, E; KLIEMANN H. J. Desordens nutricionais no cerrado. Piracicaba:POTAFOS, 1985. 136p.

MALAVOLTA, E.; NEPTUNE, A. M. L. Características e eficiência dos adubos nitrogenados. São Paulo: Centro de Pesquisa e Promoção de Sulfato de Amônio. $1983,45 p$.

MALAVOLTA, E.; VITTI, G. C.; OliveirA, S., A. de Avaliação do estado nutricional das plantas. Piracicaba:POTAFOS, 1989. $201 \mathrm{p}$.

MARSCHNER, H. Mineral nutrition of higher plants. 2.ed. San Diego: Academic Press, 1985. 889p. 
MARUN, F. Produção de matéria seca e nutrição mineral de gramíneas forrageiras em função de relação $\mathrm{Ca} / \mathrm{Mg}$ do corretivo. Lavras, 1990. 81 p. Dissertação (Mestrado) Escola Superior de Agricultura de Lavras.

MONTEIRO, F. A.; RAMOS, A. K. B.; DE CARVALHO D. D. et al. Cultivo de Brachiaria brizantha Stapf. cv. Marandu em solução nutritiva com omissões de macronutrientes. Scientia Agricola. v. 52, n.1, p. 135-141, jan./abr. 1995.

MITIDIERI, J. Manual de gramíneas e leguminosas para pastos tropicais. 2.ed São Paulo: Nobel, 1992, 198p.

MITIDIERI, F. J. Níveis de calcário em cinco gramíneas forrageiras cultivadas em solo de cerrado. Piracicaba, 1995. 156p. Dissertação (Mestrado) - Escola Superior de Agricultura "Luiz de Queiroz", Universidade de São Paulo.

NASCIMENTO, C.N.B. do; LOURENÇO JÚNIOR, J de B. Criação de búfalos na Amazônia. Belém:EMPRAPA CPTU, 1979. 20p

NOGUEIRA, A.; PAUlA, M.B.D.; CARVALHO, J. G. D.; EVANGELISTA, A. R. Efeito de diferentes relações Ca:Mg do corretivo no crescimento de capim-napier (compact disc). In: CONGRESSO BRASILEIRO DE CIÊNCIA DO SOLO, 26., Rio de Janeiro, 1997. Resumos. Rio de Janeiro: Sociedade Brasileira de Ciência do Solo, 1997.

PAULINO, V. T. Efeitos da fertilização fosfatada, da calagem e micronutrientes no desenvolvimento de plantas forrageiras. Piracicaba, 1990. 281 p. Tese (Doutorado) Escola Superior de Agricultura "Luiz de Queiroz" da Universidade de São Paulo.

PEREIRA, J. P. Adubação de capins do gênero brachiária. In: ENCONTRO PARA A DISCUSSÃO DOS CAPINS DO GÊENERO BRACHIARIA, Nova Odessa, 1986. Nova Odessa:Instituto de Zootecnia, 1986. p.35-47.

PIEDADE, M.T.F.; JUNK, W. J.; LONG, S. P. The produtivity of the $\mathrm{C}_{4}$ grass Echinochloa polystachya on the Amazon floodplain. Ecology, v.72, n.4, p.14561463. Ago. 1991.

PREMAZZI, L. M. Saturação por bases como critério para recomendação de calagem em cinco forrageiras tropicais. Piracicaba, 1991. 215p. Dissertação (Mestrado) Escola Superior de Agricultura "Luiz de Queiroz", Universidade de São Paulo. 
PRIMAVESI, A.C.P.A.; MALAVOLTA, E.; PRIMAVESI, O. Toxidez de alumínio e manganês em sorgo sacarino (Sorghum bicolor L. MOENCH).III. Relações entre P, $\mathrm{Mg}$ e Al. Anais da Escola Superior de Agricultura "Luiz de Queiroz", v.44, n.1,p.643-655, 1987.

PUPO, N. I. H. Manual de pastagens e forrageiras. Campinas: Instituto Campineiro de Ensino Agrícola, 1979. 344p.

QUAGGIO, J. A. Reação do solo e seu controle. In: SIMPÓSIO AVANÇADO DE QUÍMICA E FERTILIDADE DO SOLO, Campinas, 1986. Anais. Campinas: Fundação Cargil, 1986. p.53-89.

QUAGGIO, J. A. RAIJ, B. van; MALAVOLTA, E. Alternative use of the SMP-buffer solution to determine lime requirement of soil. Communications of Soil Science and Plant Analysis, v. 16, p.245-260, 1985.

RAIJ, B. van. Fertilidade do solo e adubação. Piracicaba:Ceres; Potafos, 1991. 343p.

RAIJ, B. van.; CAMARGO, A. P. de; CANTARELA, H.; SILVA, N. M. da. Alumínio trocável e saturação em bases como critério para recomendação de calagem. Bragantina, v.42, p.149-156, 1983.

RAIJ, B. van.; CANTARELlA, H.; QUAGGIO, J. A.; FURLANI, A. M. C. Recomendações de adubação e calagem para o Estado de São Paulo. Campinas: Instituto Agronômico, 1996. 285p. (IAC. Boletim Técnico, 100).

RAIJ, B. van; QUAGGIO, J. A ; CANTARELLA, H.; FERREIRA, M. E.; LOPES, A. S.; BATAGLIA, O. C. Análise química do solo para fins de fertilidade. Campinas:Fundação Cargil, 1987. 170p.

RITCHEY, K. D.; SILVA, J. E.; SOUSA, D. M. G. Relação entre teor de cálcio no solo e desenvolvimento de raizes avaliado por um método biológico. Revista Brasileira de Ciência do Solo, v.7, p.269-275, 1983.

RODRIGUES, J. F. Efeito de calcário - gesso agrícola na nutrição mineral e crescimento de forrageiras em Latossolo variação una. Lavras, 1992. 93p. Dissertação (Mestrado) - Universidade Federal de Lavras. 
ROSSI, C. Crescimento e nutrição do braquiarão em latossolo dos campos das vertentes (MG) sob influência da calagem e fontes de fósforo. Lavras, 1995. 65p. Dissertação (Mestrado) - Universidade Federal de Lavras.

SÁNCHEZ, P. A. Properties and management of soils in the tropics. New York: John Wiley, 1976. 618p.

SARRUGE, J. R.; HAAG, H. P. Análises químicas em plantas. Piracicaba: Livroceres, 1974. 55p.

SAS ISTITUTE. SAS users guide: statistics; version 5. Cary, 1991.

SILVA, A. P. da Toxicidade de Alumínio em trinta genótipos de Panicum maximum cultivados em solução nutritiva. Piracicaba, 1997, 149p. Tese (Doutorado) - Escola Superior de Agricultura "Luiz de Queiroz", Universidade de São Paulo.

SILVA, B. N. R.; CARVALHO, J. S. Soils of The Eastern Amazon Region. In: BURGER, D. M. Studies on the Utilization and Conservation of Soil in the Eastern Amazon Region. Postfach: F.M. Druck, 1991. 281p.

SILVA, M. A. S. Produtividade e composição mineral das garmíneas forrageiras Andropogon cv. Planaltina e colonião cv. Tobiatã submetidas a níveis de potássio, cálcio e sódio. Piracicaba, 1992. 91p. Tese (Doutorado) - Escola Superior de Agricultura "Luiz de Queiroz", Universidade de São Paulo.

SIQUEIRA, C. Calagem para Plantas Forrageiras. In: MATTOS, H. B.; WERNER, J. C.; YAMADA, T.; MALAVOLTA, E. Calagem e adubação de pastagens. Piracicaba: Associação Brasileira para Pesquisa da Potasssa e do Fosfato, 1986. 476p.

SIQUeIRA, C.; CARVAlHO, M. M. de; SARAIVA, O. F.; OLIVEIRA, F. T. T. Resposta de Três Gramíneas Forrageiras Tropicais à Aplicação de Calcário e Fósforo em um Solo Ácido. In: CONGRESSO BRASILEIRO DE ZOOTECNIA. Fortaleza, 1980. Fortaleza: SBZ, 1980. p.473.

SKERMAN, P. J.; RIVEIROS; F. Gramíneas Tropicales. Roma: FAO, 1992. 849p.

SOARES FILHO, C. V. Recomendação de Espécies e Variedades de Brachiaria para diferentes condições. In: SIMPÓSIO SOBRE MANEJO DA PASTAGEM, 11., Piracicaba, 1994. Anais. Piracicaba: FEALQ, 1994. p.25-48. 
SPAIN, J. M.; ANDREW, C. S. Mineral Characterization of Species. Six Tropical Grass $\mathrm{x}$ Four Aluminium Treataments in Water Culture. In: COMMONWEALTH SCIENTIFIC AND INDUSTRIAL RESEARCH ORGANIZATION. St. Lucia. Annual Report 1975-1976. Farnhan Royal: CAB, 1976. p50.

SPAIN, J. M.; FRANCIS, C. A.; HOWELER, R. H. et al. Differential Species and Varietal Tolerance to Soil acidity in Tropical Crops and Pastures. In: BORNEMISZA, E; ALVARADO, A. Soil management in tropical America. Cali:CIAT, 1975. p. 313-335.

SUTTON, M. Níveis de calcário e de potássio em um latossolo vermelho-amarelo para quatro cultivares de alfafa. Piracicaba, 1993. 123p. Dissertação (Mestrado) - Escola Superior de Agricultura "Luiz de Queiroz", Universidade de São Paulo.

TAN, K. Z.; KELTJENS, W. G. Analysis of acid-soil stress in sorghum genotypes with emphasis on aluminum and magnesium interactions. Plant and Soil, v.171, p.147$150,1995$.

THOMAS, G. W.; HARGROVE, W. L. The chemistry of soil acidity. In: ADAMS, F. Soil acidity and liming. Madson:ASA; CSSA; SSSA, 1994. 380p.

TILLEY, J.M.; TERRY, R.A. A two stage technique for the "in vitro" digestion of forage crops. Journal of British Grassland Society, v.18, p.104-111, 1963.

TINNIMIT, P. Forage evaluation using various laboratory techniques. East Lansing, 1974. Thesis (Ph.D.) - Michigan State University.

TISDALE, S. L.; BEATON, J. D.; NBELSON, W. L. Soil fertility and fertilizers. New York: MacMillan, 1985. 754p.

VAN SOEST, P.J.; ROBERTSON, J.B.; LEWIS, B.A. Methods for dietary fiber, neutral detergent fiber, and nonstarch polysaccharides in relation to animal nutrition. Journal of Dairy Science, v.74, p. 3583. 1991.

VICENTE-CHANDLER, J.; SILVA, S.; FIGARELLA, J. Effects of nitrogen fertilization and frequency of cutting on the yield and composition of Napier grass in Porto Rico. The Journal of Agriculture of the University of Porto Rico, v.43, n.4, p.215-227, 1959a. 
VICENTE-CHANDLER, J.; SILVA, S.; FIGARELLA, J. Effects of nitrogen fertilization and frequency of cutting on the yield and composition of Guinea grass in Porto Rico. The Journal of Agriculture of the University of Porto Rico, v.43, n.4, p.228-239, 1959 b.

VICENTE-CHANDLER, J.; SILVA, S.; FIGARELLA, J. Effects of nitrogen fertilization and frequency of cutting on the yield and composition of Para grass in Porto Rico. The Journal of Agriculture of the University of Porto Rico, v.43, n.4, p.240-248, 1959c.

VITTORI, A.; SILVA, J. F. C.; VASQUEZ, H. M.; SILVA, L. C. C.; GAMA FILHO, R.V. Produção de matéria seca de gramíneas tropicais (compact disc). In:REUNIÃO ANUAL DA SOCIEDADE BRASILEIRA DE ZOOTECNIA, 35., Botucatu, 1998. Anais. Botucatu: SBZ, 1998.

WERNER, J. C. Calagem para plantas forrageiras. In: PEIXOTO, A. M.; MOURA, J. C. DE; FARIA, V. P. de. Pastagens: fundamentos da exploração racional. 2.ed. Piracicaba: FEALQ, 1986. 379p.

WERNER, J. C. Adubação de pastagens de Brachiaria spp.. In: SIMPÓSIO SOBRE MANEJO DA PASTAGEM, 11. Piracicaba, 1994. Anais. Piracicaba: FEALQ, 1994. p.209-222.

WERNER, J. C; MONTEIRO, F. A.; CARRIEL, J. M. Efeitos da calagem em capimcolonião (Pannicum maximum Jacq) estabelecido. Boletim da Indústria Animal, v.36, p.247-53, jun./dez., 1979.

WERnER, J. C; PAUlinO, V. T.; CANTARElla, H.; ANDRADE, N. de O.; QUAGGIO, J. A. Forrageiras. In: RAIJ, B. van; CANTARELLA, H.; QUAGGIO, J. A.; FURLANI, A. M. C. Recomendações de adubação e calagem para o estado de São Paulo. Campinas: Instituto Agronômico, 1996. p.261-273. (IAC. Boletim Técnico, 100).

WILDIN, J. H. Echinochloa polystachya (H.B.K) Hitchcock (aleman grass) cv. Amity. Australian Journal of Experimental Agriculture, v.29, n.2, p.294, Nov. 1989. 
APÊNDICE 
Tabela 1- Tabela com as Temperaturas $\left({ }^{\circ} \mathrm{C}\right)$ e Umidade relativa $(\%)$ da casa de vegetação onde foram cultivadas as forrageiras.

\begin{tabular}{|c|c|c|c|c|c|c|c|c|c|}
\hline \multirow{2}{*}{ Data } & \multicolumn{2}{|c|}{$6: 00 \mathrm{~h}$} & \multicolumn{2}{|c|}{$12: 00 \mathrm{~h}$} & \multicolumn{2}{|c|}{$18: 00 \mathrm{~h}$} & \multirow{2}{*}{$\begin{array}{c}\mathrm{T} \\
\text { minima }\end{array}$} & \multirow{2}{*}{$\begin{array}{c}\mathrm{T} \\
\text { máxima }\end{array}$} & \multirow{2}{*}{$\begin{array}{c}T \\
\text { média* }\end{array}$} \\
\hline & Temp & Umid & Temp & Umid & Temp & Umid & & & \\
\hline $01 /$ nov & 13 & 100 & 34 & 40 & 29 & 42 & 13 & 38 & 25,4 \\
\hline $02 /$ nov & 15 & 100 & 34 & 40 & 28 & 46 & 15 & 38 & 26,0 \\
\hline 03/nov & 19 & 93 & 35 & 39 & 27 & 48 & 18 & 38 & 27,4 \\
\hline $04 /$ nov & 18 & 100 & 35 & 38 & 28 & 53 & 18 & 40 & 27,8 \\
\hline $05 /$ nov & 22 & 100 & 26 & 67 & 24 & 80 & 22 & 28 & 24,4 \\
\hline $06 /$ nov & 18 & 100 & 34 & 43 & 28 & 45 & 18 & 39 & 27,4 \\
\hline 07/nov & 15 & 100 & 34 & 41 & 32 & 39 & 15 & 40 & 27,2 \\
\hline 08/nov & 17 & 100 & 37 & 42 & 28 & 57 & 17 & 41 & 28,0 \\
\hline 09/nov & 22 & 98 & 29 & 55 & 22 & 82 & 22 & 35 & 26,0 \\
\hline $10 /$ nov & 18 & 98 & 30 & 46 & 22 & 63 & 18 & 33 & 24,2 \\
\hline $11 /$ nov & 22 & 98 & 31 & 45 & 28 & 50 & 14 & 32 & 25,4 \\
\hline $12 /$ nov & 20 & 100 & 24 & 80 & 24 & 90 & 20 & 41 & 25,8 \\
\hline $13 /$ nov & 20 & 100 & 29 & 59 & 23 & 79 & 20 & 38 & 26,0 \\
\hline $14 /$ nov & 19 & 100 & 34 & 43 & 25 & 80 & 18 & 42 & 27,6 \\
\hline $15 /$ nov & 14 & 100 & 30 & 48 & 25 & 53 & 14 & 35 & 23,6 \\
\hline $16 /$ nov & 13 & 100 & 34 & 43 & 25 & 51 & 13 & 37 & 24,4 \\
\hline $17 /$ nov & 14 & 100 & 35 & 40 & 31 & 38 & 14 & 39 & 26,6 \\
\hline $18 /$ nov & 14 & 100 & 34 & 45 & 32 & 40 & 14 & 37 & 26,2 \\
\hline $19 /$ nov & 14 & 100 & 38 & 42 & 32 & 41 & 14 & 40 & 27,6 \\
\hline $20 /$ nov & 17 & 100 & 33 & 44 & 24 & 83 & 17 & 40 & 26,2 \\
\hline $21 /$ nov & 18 & 100 & 37 & 41 & 30 & 47 & 18 & 38 & 28,2 \\
\hline $22 /$ nov & 18 & 100 & 36 & 42 & 29 & 54 & 18 & 42 & 28,6 \\
\hline $23 /$ nov & 17 & 100 & 36 & 40 & 24 & 80 & 17 & 39 & 26,6 \\
\hline $24 /$ nov & 18 & 100 & 36 & 45 & 32 & 49 & 18 & 42 & 29,2 \\
\hline $25 /$ nov & 16 & 100 & 37 & 36 & 32 & 39 & 16 & 38 & 27,8 \\
\hline $26 /$ nov & 22 & 100 & 27 & 68 & 30 & 56 & 22 & 35 & 27,2 \\
\hline $27 /$ nov & 19 & 100 & 37 & 40 & 31 & 41 & 19 & 38 & 28,8 \\
\hline 28/nov & 16 & 100 & 37 & 39 & 31 & 46 & 16 & 40 & 28,0 \\
\hline $29 /$ nov & 17 & 100 & 37 & 40 & 33 & 40 & 17 & 40 & 28,8 \\
\hline $30 /$ nov & 15 & 100 & 36 & 45 & 30 & 53 & 15 & 42 & 27,6 \\
\hline Média: & 17,33 & 99,57 & 33,53 & 45,87 & 27,97 & 55,50 & 17,00 & 38,17 & 26,80 \\
\hline
\end{tabular}

*-Obtida pela média das temperaturas das 6:00h;12:00h;18:00;máxima e mínima do dia 
Tabela 1 (continuação)- Tabela com as Temperaturas $\left({ }^{\circ} \mathrm{C}\right)$ e Umidade relativa $(\%)$ da casa de vegetação onde foram cultivadas as forrageiras.

\begin{tabular}{|c|c|c|c|c|c|c|c|c|c|}
\hline \multirow{2}{*}{ Data } & \multicolumn{2}{|c|}{$6: 00 \mathrm{~h}$} & \multicolumn{2}{|c|}{$12: 00 \mathrm{~h}$} & \multicolumn{2}{|c|}{$18: 00 \mathrm{~h}$} & \multirow{2}{*}{$\begin{array}{c}\mathrm{T} \\
\text { minima }\end{array}$} & \multirow{2}{*}{$\begin{array}{c}\mathrm{T} \\
\text { máxima }\end{array}$} & \multirow{2}{*}{$\begin{array}{c}\mathrm{T} \\
\text { média* }\end{array}$} \\
\hline & Temp & Umid & Temp & Umid & Temp & Umid & & & \\
\hline $01 / \mathrm{dez}$ & 18 & 100 & 36 & 44 & 31 & 49 & 18 & 40 & 28,6 \\
\hline $02 / \mathrm{dez}$ & 18 & 100 & 38 & 42 & 28 & 55 & 18 & 42 & 28,8 \\
\hline $03 / \mathrm{dez}$ & 21 & 100 & 33 & 48 & 25 & 80 & 21 & 40 & 28,0 \\
\hline $04 / \mathrm{dez}$ & 21 & 100 & 38 & 46 & 25 & 80 & 21 & 38 & 28,6 \\
\hline $05 / \mathrm{dez}$ & 19 & 100 & 39 & 47 & 30 & 60 & 19 & 41 & 29,6 \\
\hline $06 / \mathrm{dez}$ & 21 & 96 & 34 & 49 & 26 & 70 & 21 & 38 & 28,0 \\
\hline 07/dez & 22 & 100 & 37 & 47 & 28 & 70 & 22 & 40 & 29,8 \\
\hline 08/dez & 22 & 100 & 44 & 40 & 26 & 80 & 22 & 44 & 31,6 \\
\hline 09/dez & 22 & 100 & 40 & 42 & 32 & 52 & 22 & 40 & 31,2 \\
\hline 10/dez & 22 & 100 & 33 & 52 & 24 & 95 & 22 & 39 & 28,0 \\
\hline 11/dez & 21 & 95 & 28 & 67 & 25 & 78 & 21 & 31 & 25,2 \\
\hline $12 / \mathrm{dez}$ & 20 & 98 & 26 & 65 & 21 & 70 & 20 & 37 & 24,8 \\
\hline $13 / \mathrm{dez}$ & 22 & 100 & 32 & 58 & 21 & 100 & 21 & 32 & 25,6 \\
\hline 14/dez & 20 & 100 & 29 & 60 & 29 & 67 & 20 & 31 & 25,8 \\
\hline 15/dez & 21 & 98 & 34 & 50 & 30 & 44 & 21 & 44 & 30,0 \\
\hline 16/dez & 18 & 100 & 37 & 40 & 32 & 38 & 18 & 38 & 28,6 \\
\hline 17/dez & 17 & 100 & 37 & 40 & 34 & 40 & 17 & 40 & 29,0 \\
\hline 18/dez & 18 & 100 & 39 & 40 & 36 & 35 & 18 & 43 & 30,8 \\
\hline 19/dez & 19 & 100 & 39 & 42 & 35 & 41 & 19 & 42 & 30,8 \\
\hline 20/dez & 21 & 100 & 41 & 35 & 37 & 32 & 21 & 42 & 32,4 \\
\hline $21 / \mathrm{dez}$ & 19 & 100 & 39 & 45 & 35 & 40 & 19 & 42 & 30,8 \\
\hline 22/dez & 20 & 100 & 39 & 45 & 23 & 100 & 20 & 39 & 28,2 \\
\hline 23/dez & 20 & 100 & 34 & 50 & 31 & 52 & 20 & 34 & 27,8 \\
\hline 24/dez & 19 & 100 & 31 & 46 & 25 & 90 & 19 & 38 & 26,4 \\
\hline 25/dez & 20 & 100 & 36 & 57 & 24 & 46 & 20 & 40 & 28,0 \\
\hline 26/dez & 21 & 100 & 41 & 44 & 31 & 65 & 21 & 42 & 31,2 \\
\hline 27/dez & 23 & 100 & 36 & 47 & 25 & 93 & 22 & 41 & 29,4 \\
\hline 28/dez & 21 & 100 & 39 & 46 & 34 & 44 & 21 & 41 & 31,2 \\
\hline 29/dez & 21 & 100 & 39 & 42 & 36 & 41 & 21 & 41 & 31,6 \\
\hline 30/dez & 22 & 100 & 40 & 46 & 37 & 44 & 22 & 42 & 32,6 \\
\hline 31/dez & 24 & 100 & 32 & 60 & 29 & 68 & 24 & 41 & 30,0 \\
\hline 01/jan & 23 & 100 & 35 & 60 & 25 & 96 & 23 & 37 & 28,6 \\
\hline $02 /$ jan & 22 & 100 & 25 & 85 & 24 & 90 & 22 & 31 & 24,8 \\
\hline 03/jan & 20 & 100 & 31 & 60 & 25 & 90 & 20 & 36 & 26,4 \\
\hline 04/jan & 21 & 100 & 32 & 50 & 26 & 85 & 21 & 40 & 28,0 \\
\hline Média: & 20,54 & 99,63 & 35,51 & 49,63 & 28,71 & 65,14 & 20,49 & 39,06 & 28,86 \\
\hline
\end{tabular}

*-Obtida pela média das temperaturas das 6:00h;12:00h;18:00;máxima e mínima do dia 